QK143

B22

1914 


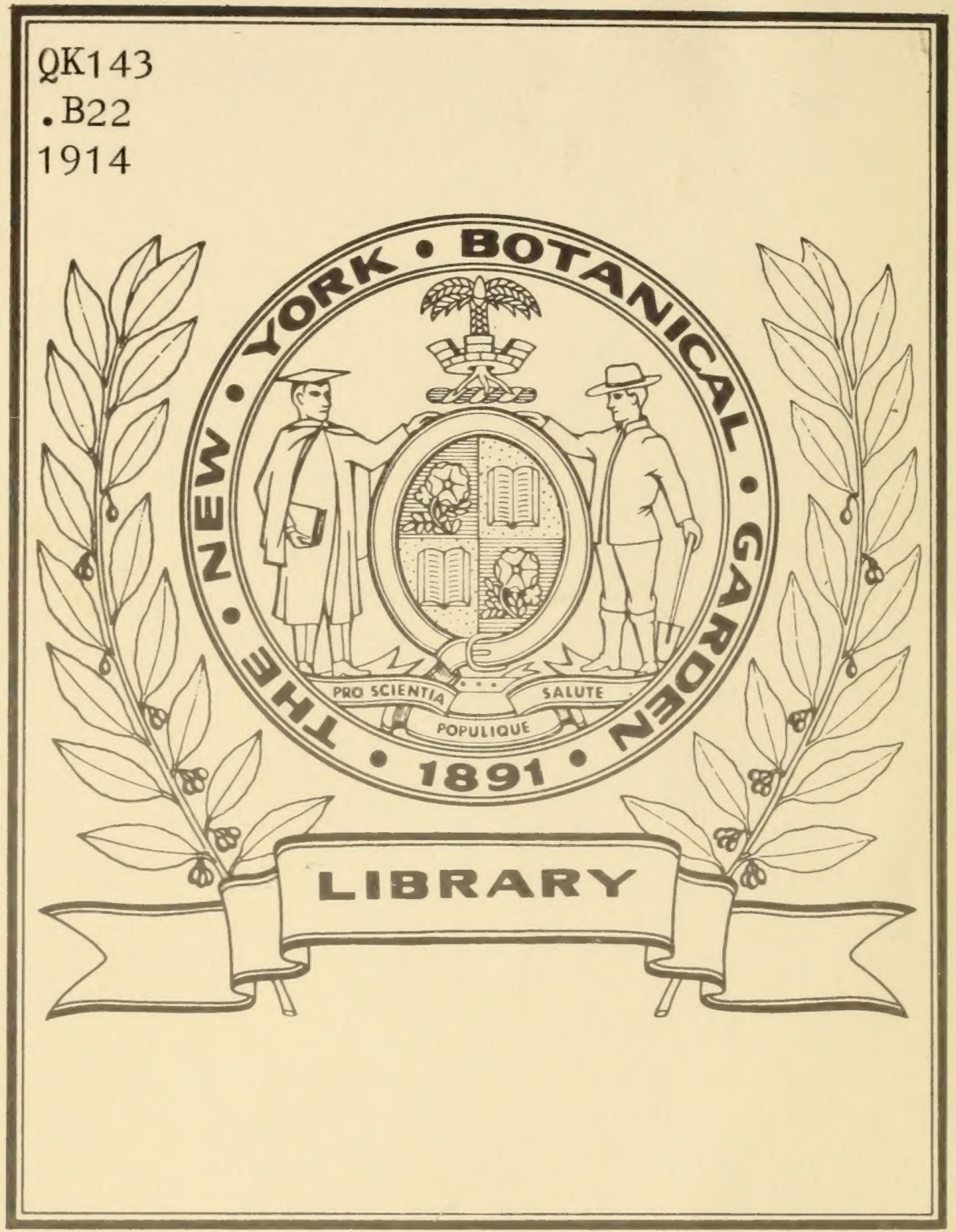





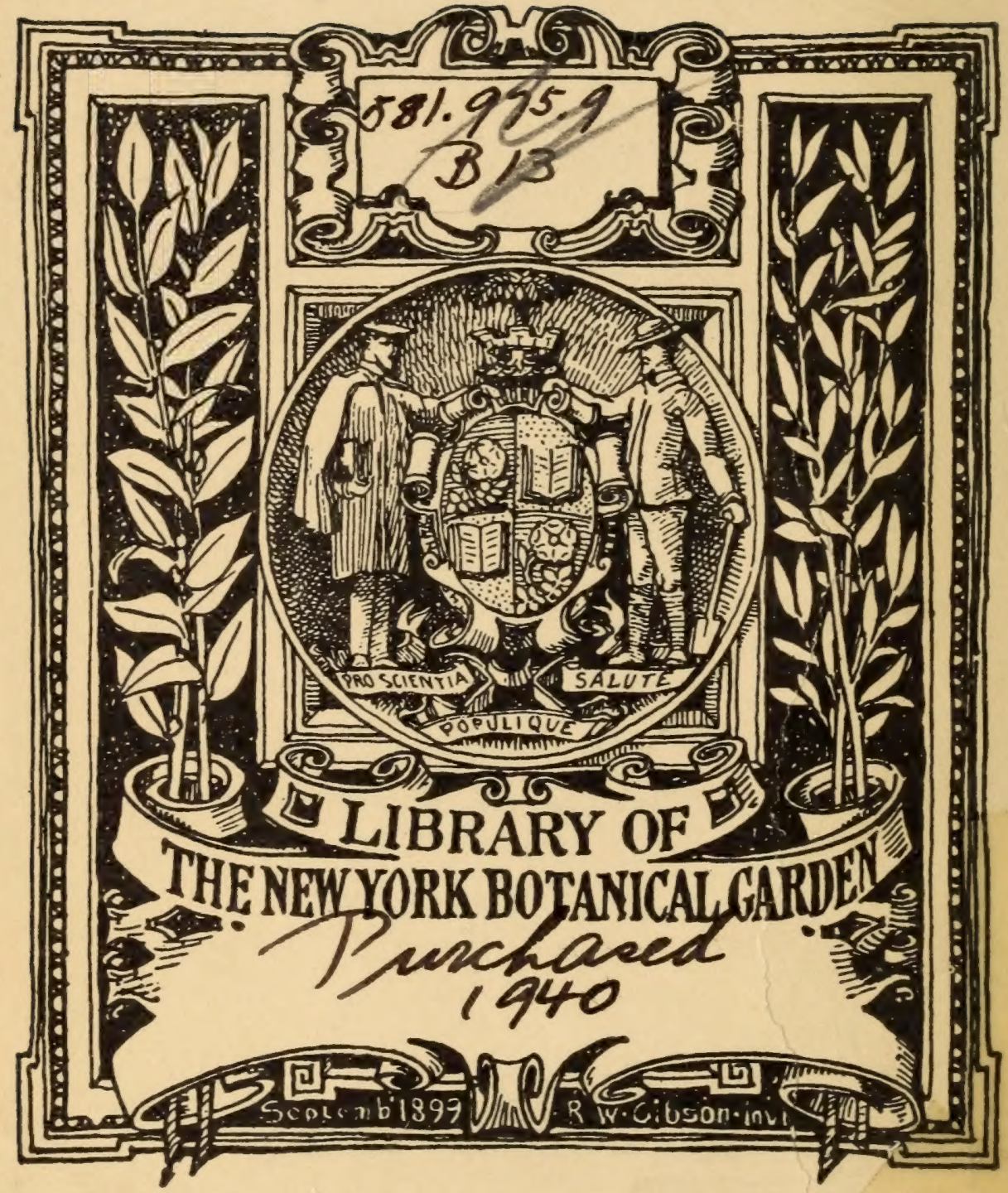





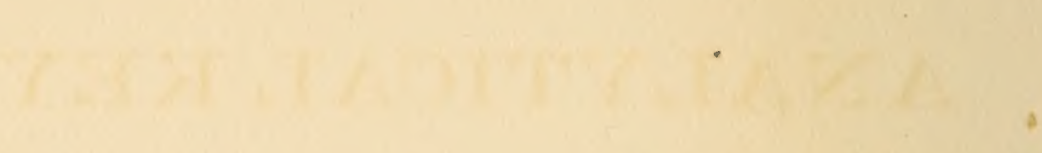

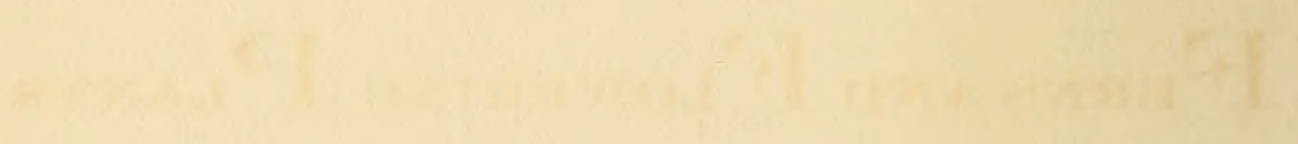

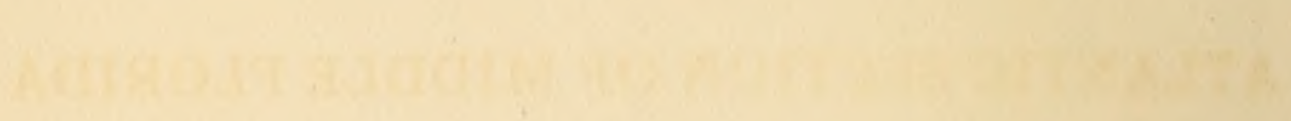




\title{
ANALYTICAL KEY
}

\author{
TO THE
}

Frans and $\mathrm{F}_{\text {lowering }} \mathrm{P}_{\text {lants }}$

IN THE

\section{ATLANTIC SECTION OF MIDDLE FLORIDA}

(WILD AND CULTIVATED)

$-\mathrm{BY}-$

LIBRARY

NEW

BOT NACAL

JOHN F. BAERFCKE, Ph.D.. M.D.

Professor of Biology in John B. Stetson University, DeLand, Florida

SECOND EDITION. 
$Q K 143$
1322
1914

COPYRIGHT, 1906

By JOHN F. BAERECKE.

COPYRIGHT, 1914 By JOHN F. BAERECKE. 


\section{PREFACE.}

The Key is intended as an aid to students, beginning field-work in Botany; in this second edition the plants have been restricted mainly to those collected in Volusia County.

For more complete descriptions than those given here, the student should consult: Dr. J. K. Small, Flora of the South-eastern United States, publ. by the author, Bedford Park, New York City;-Dr. A. W. Chapman, Flora of the Southern United States, publ. by the American Book Company;-Dr. Bailey's Cyclopedia of American Horticulture, publ. by the MacMillan Co. The arrangement of the Families is that based upon Dr. Engler's Syllabus der Pflanzenfamilien, and commonly accepted in present day Botany.

If two names are mentioned in the Key for the same wild plant, the former will be found in Small's Flora, and the latter (in parenthesis) in Chapman's Flora.

The student's record of an analysis, either in the field or in the laboratory, may be written in his note-book as follows:

Number, Date, Locality, Soil, if a wild plant, otherwise simply write: Cullivated.

Spermatophyte

Angiosperm

Monocotyledon

$1 b-8 c-10 a-11 a-$ fam. Orchidaceae

1b-4a-5a-genus: Limodorum (Calopogon)

Specimen: L. pallidum (C. pallidus), Grass Pink.

Another example:

Number, Date, Locality, Soil.

Spermatophyte

Angiosperm

Dicotyledon 
$1 c-82 b-83 b-87 b-93 b-96 c-98 a-99 c-101 c-$

fam. Acanthaceae.

1b-2b-genus: Ruellia

Specimen: R. strepens.

It is soon easily seen when a flower belongs to the Compositæ; in such a case the record would be for instance:

Number, Date, Location, Soil.

Spermatophyte

Angiosperm

Dicotyledon

$113 \mathrm{~b}-118 \mathrm{~b}-$ fam. Carduaceae.

$1 b-12 a-13 a-14 b-18 b-21 b-22 b-$ genus; Aster.

$a 2-b 1-c 2-e 1-$ Species; dumosus.

Specimen: Aster dumosus. sidered.

Suggestions for improvement will be carefully con-

November 1914.

J. F. B.

\section{CONTENTS.}

Introduction ................................................................

List of the Orders............................................................... 8

Key to the Families................................................ 9

Key to the Genera and Species...................................... 19

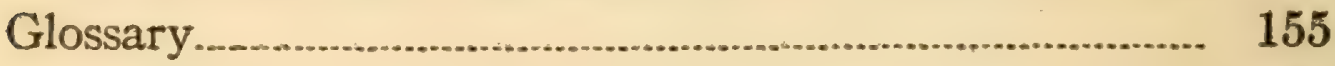

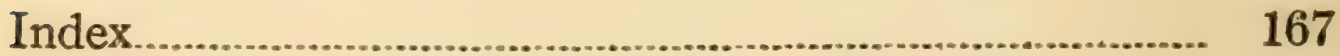




\section{INTRODUCTION.}

Volusia County in Florida has a surface of 1281 square miles, that is about $30 \mathrm{sq} . \mathrm{m}$. more than the State of Rhode Island. The parallel of 29 degrees, running a little south of New Smyrna and DeLand, is equidistant from the northern boundary line and the most southern point of the county; the two distances are about twenty-three and a half minutes north and south of the parallel.

Along its western and southwestern boundaries runs the St. John's river, while the eastern boundary is on the Atlantic Ocean. Parallel with the coast-line and separated by a narrow strip of land from the ocean are the "Halifax River" and "Mosquito Lagoon," which communicate with the ocean and with one another through Mosquito-inlet. Another arm of the ocean "Indian River" makes part of the southern boundary of the county. In connection with the St. John's are the lakes Harney and Monroe in the southwest; Beresford, Woodruff, Dexter and George in the west; the southern part of lake Crescent on the northern boundary line. Lakes Disston, Ashby, and a number of lakes of lesser size are scattered over the county. Many surface streams and the artesian wells (containing sulphuretted hydrogen) along the border of the Atlantic on the east, and along the St. John's river on the west provide for sufficient natural drainage. Some of these artesian wells and also several springs supply water that is more or less salty, and when this water is allowed to run into small streams or lakes (Harney, Monroe, and Crescent for instance) their water-and shore- vegetation becomes affected.

Close to the sea-coast are SALT MARSHES and SAND DUNES of recent and earlier formation; Mount Ararat for instance, two miles west of Daytona is an ancient sand-dune. Along the western bank of the Halifax river and Mosquito lagoon 
lies HAMMOCK-LAND several miles wide; the soil of rich humus is underlaid by limestone and marl, or by a yellow sand, and supports a heavy growth of hardwood trees and cabbage palmettoes. West of this tract is a belt of PRAIRIE, open lands devoid of trees, which is due to overflow during the rainy season. The soil consists of light-colored sand underlaid by clay or by hardpan; the native growth consists of grasses. As a rule the prairies occupy basins depressed below the level of the surrounding country, which is covered with pine and cabbage-palmetto.

Further west, from the northern boundary of the county southward for about thirty miles, and from two to six miles wide is HIGH ROLLING PINE country. Its soil is a welldrained sandy loam, carrying a native vegetation of pine and wire-grass, interspersed with oak and other hardwood trees. Small areas of high pine-land are scattered throughout the eastern part of the county. South of this is ROLLING PINE-SHRUB, very sandy, with a dense growth of shrubby plants, until the St. John's river is reached with its varying banks of hammock, prairie, and swamp-land.

The remaining part of the county consists of FLATwOoDs, interspersed with cypress- and cedar-ponds. The native vegetation of the PALMETTO-FLATWOODS is chiefly pine, saw-palmetto and wire-grass. The surface is a dark sand, as a rule not well drained, the underlying "hardpan" where the sand contains tannic or other organic acids and iron, preventing the free movement of the water. When the saw-palmetto is absent the flatwoods are called open. The OPEN FLATWOODS are dark gray with a subsoil of clay or sand, and no hardpan; its vegetation is chiefly pine and wire-grass with little or no underbrush. (Compare: Dr. E. H. Sellards "Classification of the soils of Florida"; also his fifth annual report of "Florida State Geological Survey.")

The mean temperatures for January-December are resp: $57,59,65,67,73,78,80,80,78,73,66,58$ (degrees Fahr.), although the thermometer may go up to 100 , while the lowest temperature recorded is $16 \mathrm{~F}$.

The mean precipitation for January-December is resp.: $2.8,3.6,2.6,1.6,2.6,6.2,5.6,5.6,9.2,6.7,2.6,2.0$ (inches). Annual rainfall 51.1 inches, (U. S. Weather Bureau.) 
The principal factors which give rise to slow or sudden changes in the natural vegetation are:

successive cold seasons which invite northern and drive out southern species;-

successive warm seasons which do the reverse; -

very wet or very dry seasons which cause the filling or emptying of ponds;-

the natural sanding in of lakes, narrowing their borders; extension and regression of the sand-dunes;-

influence of salty and sulphury water from springs;changes in the scattering of seeds by wind and birds and altered water-courses;-

the cutting of roads and canals;-

the cutting of pine-woods for turpentine or lumber, which is going on over large areas, and which modifies the amount of moisture and shade; -

the taking of land into cultivation, for truck or citrusplanting:-

and other less visible causes for the appearance of some species and the disappearance of other species, for instance along the roadside in and near the towns. 


\section{List of the Orders containing the following Families.}

Ophioglossales: fam. 1

Filicales: fam. 2, 3

Lycopodiales: fam. 4-6

Isoetales: fam. 7

Cycadales: fam. 8

Pinales: fam. 9, 10

Pandanales: fam. 11-13

Naiadales: fam. 14

Alismales: fam. 15

Hydrocharitales: fam. 16,1

Poales: fam. 18, 19

Arecales: fam. 20

Arales: fam. 21,22

Xyridales: fam. 23-28

Liliales: fam. $29-35$

Amaryllidales: fam. 36-39

Scitiminales: fam. $40-43$

Orchidales: fam. 44,45
Piperales: fam. 46,47

Juglandales: fam. 48

Myricales: fam. 49

Salicales: fam. 50

Fagales: fam. 51,52

Urticales: fam. $53-56$

Polygonales: fam. 57

Chenopodiales: fam. 58-67 Primulales: fam. 137, 138

Ranales: fam. $68-74$

Papaverales: fam. $75-77$

Saraceniales: fam. 78, 79

Rosales: fam. $80-93$

Geraniales: fam. 94-99

Polygalales: fam. 100

Euphorbiales: fam. 101, 102 Santalales: fam. 164

Sapindales: fam. 103-108 Rubiales: fam. 165, 166

Rhamnales: fam. 109, 110 Valerianales: fam. 167

Malvales: fam. 111, 112

Hypericales: fam. 113-117

Passiflorales: fam. 118
Opuntiales: fam. 119

Begoniales: fam. 120

Proteales: fam. 121

Thymeleales: fam. 122, 123

Myrtales: fam. 124-130

Ammiales: fam. 131-133

Ericales: fam. 134-136

Ebenales: fam. 139, 140

Oleales: fam. 141

Gentianales: fam. 142-144

Asclepiadales: fam. 145, 146

Polemoniales: fam. 147-162

Plantaginales: fam. 163

Aristolochiales: fam. 168

Campanulales: fam. 169-171

Carduales: fam. 172-174 


\section{KEY TO THE FAMILIES.*}

Plants with woody and vascular tissues, producing spores-

Subkingdom of Pteridophyta

Plants producing seeds,

Subkingdom of Spermatophyta

\section{Pteridophyta.}

1. Leaves broad, entire or dissected, - - - - - - - 2

1. Leaves scale-like or awl-like, _ - _ _ - _ - - - 4

2. Vemation straight or inclined, - - - - - 1 Ophioglossaceae

2. Vernation coiled, - _ - - - - _ - - _ - 3

3. Sporanges round or nearly so, in panicles or spikes, - -2 Osmundaceae

3. Sporanges on the back or margin of the leaf-blades, terrestrial or

epiphytic plants, - _ - _ _ _ - $\quad$ - 3 Polypodiaceae

4. Leaves scale-like, plants terrestrial, - _ - _ - - - 5

4. Leaves awl-like, plants aquatic, - _ - _ - 7 Isoetaceae

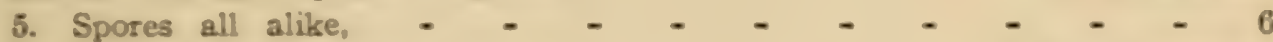

5. Spores of two sizes, - - - - - - 6 Selaginellaceae

6. Stems leafy, - - - - - - - - - - 4 Lycopodiaceae

6. Stems and branches almost naked, - _ - - - 5 Psilotacae

\section{Spermatophyta.}

Ovules not contained in an ovary. - - - _ - - Class of Gymnospermae Ovules contained in an ovary - _ - - - - Class of Angiospermae

\section{GYMNOSPERMAE.}

1. Plants growing by a single terminal bud; low, palm-like, - 8 Cycadaceae

1. Plants growing by terminal and latera! buds; shrubs or trees with

scale-like or needle-like leaves. _ _ _ _ _ - - 2

2. Carpellary scales with bracts, not peltate, - - - - 9 Pinaceae

2. Carpellary scales without bracts, peltate or fleshy, - - 10 Juniperaceae

\section{ANGIOSPERMAE.}

Leaves generally parallel-veined, flowers usually 3 or 6 parted-

Subclass of Monocotyledones, page 10

Leaves generally pinnately or palmately veined, flowers rarely 3 or 6 parted-

Subclass of Dicotyledones, page 11

- The numbers before the rames of the Families indicate the order in which they are described and analyzed in the Key to the Genera and Spectes, page 19. 


\section{Monocotyledones.}

1. Perianth consisting of bristles or scales, or wanting, not corolla-like, - 2

1. Perianth of one or two rows, the inner usually corolla-like, - $\quad-8$

2. Flowers glumaceous, - - - - - 18 Grasses and 19 Sedges

2. Flowers not glumaceous, - - - - - - - - - - 3

3. Perianth consisting of bristles or scales, or wanting, - _ - - 4

3. Perianth fleshy or herbaceous, or wanting, - - - - 6

4. Plants more or less woody, with stilt-like aerial roots; cultivated.-

12 Pandanaceae

4. Wild plants.

5. Flowers in elongated terminal spikes, - - - 11 Typhaceae

5. Flowers in globose axillary spikes, - - - - 13 Sparganiaceae

5. Flowers in lateral panicles, corymbs or heads, rarely single, - 30 Juncaceae

6. Fruit a berry or utricle, - - - - - - - - - 7

6. Fruit a spike of drupelets; submerged herbs, - . - 14 Zannichelliaceae

7. Plants with flowers on a spadix, - - - - - 21 Araceae

7. Minute floating herbaceous structures, - - - - 22 Lemnaceae

8. Epiphytes, - - - - - - - - - 28 Bromeliaceae

8. Trees and shrubs, with caudex, - - - - - - - 9

8. Herbs or vines, - - - - - - - - - - - 10

9. Leaves alternate, narrow, firm or rigid, - - - $\quad-34$ Dracaenaceae

9. Leaves at the end of the stem, fanshaped or pinnate, - - $\mathbf{2 0}$ Arecaceae

10. Flowers mainly in heads or spikes, - - - - - - - 11

10. Flowers in other inflorescences, or single - - - - - -13

11. Stamens united with the style, - - - - 45 Orchidaceae

11. Stamens and style not united, - - - - - - - 12

12. Flowers yellow or white, in terminal compact spikes, - - 24 Xyridaceae

12. Flowers white, minute, in terminal involucrate heads, - 25 Ericaulonaceae

12. Flowers blue, or white, or purplish with yellow dots, in spikes, rarely

single or in a raceme, - - - - - $\quad 27$ Pontedariaceae

12. Flowers pink or purple, in bracted clusters arranged in a drooping terminal spike, - - - - - - - - 40 Musaceae

12. Flowers orange-yellow and white in a spike, a head, or a drooping panicle, - - - - - - - - - 41 Alpiniaceae

12. Flowers bluish-purple in an erect terminal leafy-bracted spike - $\mathbf{2 8}$ Bromeliaceae

13. Ovary superior, - - - - - - - - - - 14

13. Ovary wholly or partially inferior, - - - - - - 23

14. The two rows of the perianth of different color, - - - - - 15

14. The two rows of the perianth of the same color, - - - - 18

15. Carpels 3-many, distinct, - - _ - - - - 15 Alismaceae

15. Carpels 3, more or less united, - _ - _ - _ - 16

16. Leaves densely crowded, moss-like marsh-herbs, _ _ _ 23 Mayacaceae

16. Leaves alternate, - - - - - - - - - + - 17

17. Stigma 1, obscurely lobed, - _ _ _ - 26 Commelinaceae

17. Stigmas 3; epiphytes, - _ _ - _ - 28 Bromeliaceae

18. Leaves net-veined; vines, - _ - - _ - 35 Smilacaceae

18. Leaves parallel-veined, often narrow, - - - - - - - 19

18. Leaves reduced to scales, branches thread-like, - - $\mathbf{3 3}$ Convallariaceae

19. Styles united, - - - - - - - - - - 20

19. Styles 3, distinct, - - - - - - - 29 Melanthaceae 
20. Flowers regular, - - - - - - - - - 21

20. Flowers more or less irregular, - $\quad$ - $\quad$ - $\quad$ - 27 Pontedariaceae

21. Plants with bulbs or corms, - - - _ - - - 22

21. Plants with rootstocks, - - _ - - $\quad$ - 33 Convallariaceee

22. Plowers in umbels, with a scarious involucre, - _ $\quad 31$ Alliaceae

22. Plowers solitary, or in racemes or panicles, without involucre, $\mathbf{3 2}$ Liliaceae 23. Stamens and pistils united, flowers irregular, - - 5 Orchidaceae

23. Stamens and pistils separate, - _ _ _ - - -24

24. Flowers monoecious or dicecious, - - - - - - - 25

24. Flowers perfect, - - - - - - - - - - - 27

25. Flowers arising Jrom spathes; aquatics, - _ _ - 26

25. Flowers without spathes; twining vines, - _ - 37 Tamaceae

26. Ovary 1-celled, stigmas usually 3, - _ _ - 16 Elodeaceae

26. Ovary 6-9-celled, stigmas 6-9, each 2-parted, _ _ - 17 Hydrocharitaceae

27. Perianth $\mathrm{p} u$ bescent, - - _ - - - - 39 Haemodoraceae

27. Perianth glabrous, - - - - - - - - - - 28

28. Some stamens petaloid, - - - - - - - - - - 29

28. No stamens petaloid, - - - - - - - - - - 30

29. One stamen with a marginal anther, _ _ _ _ 43 Cannaceae

29. One stamen with a 1-celled anther, _ _ _ - 12 Marantaceae

30. Stamens 3, anther 1, 2-celled, - - - - - 11 Alpiniacere

30. Stamens 3, anthers 3, - - - - - - - - - - 31

30. Stamens 6, - - - - - - - - - 36 Leucojaceae

31. Pilaments filiform, anthers extrorse, - _ - - 39 Iridaceae

31. Filaments short, anthers with long connectives, - 14 Burmanniaceae

\section{Dicotyledones.}

1. Corolla wanting (A petaloe) - - - - - - - 2

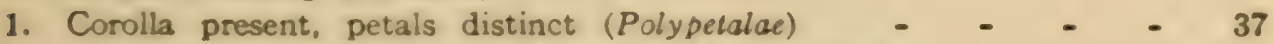

1. Corolla present, petals more or less united (Gamopelalae) - _ $\quad$ - $\quad$ - 82

2. Calyx wanting, at least in the staminate flowers, - - -3

2. Calyx present, sometimes colored, at least in the staminate and in the perfect flowers, - - _ - - - - _ - - 9

3. Aquatic herbs with monœecious flowers, surrounded by an involucre, - _ _ _ _ - _ - 68 Ceratophyllaceae

3. Terrestrial herbs, - - - - - - - - - - 4

3. Shrubs and trees, flowers rarely perfect, - - - - - - - 6

4. Flowers perfect or polygamous, - - _ _ - - - 5

4. Flowers monoocious or dioecious, - - _ - - 101 Euphorbiaceae

5. Stamens 3-8, carpels almost distinct, stigmas 3-4, - 46 Saururaceae

5. Stamens rarely more than 2 , carpels united, stigma brush-like, $\mathbf{1 7}$ Piperaceae

5. Stamen 1, ovary 4-celled, styles united in pairs, - 102 Callitrichaceae

6. Plowers in aments, - - - - - - - - - - 7

6. Plowers not in aments, - - - - - - - - - 8

7. Ovule solitary, fruit a drupe-like nut, - - - 49 Myricaceae

7. Ovule solitary. fruit a nut enclosed in a bract, - $\quad 51$ Corylaceae

7. Ovules numerous, fruit a capsule, seeds with coma, - 50 Salicaceae

8. Flcwers in heads, fruit consisting of capsules united into a globose head,

8. Flowers not in heads, fruit a samara or a drupe, - . 111 Olenceac 
9. At least the staminate flowers in aments, or ament-like spikes or heads, - - _ - - - - - - - - 10

9. Staminate flowers not in aments, - - - _ - -.12

10. Leaves simple, - - - - - - - - - - - 11

10. Leaves pinnately compound; fruit a nut surrounded by a hard or

fibrous husk, - - - - - - - - -48 Juglandaceae

11. Fruit a nut, surrounded by a scaly or spiny involucre, (cup or burr.) - - _ - _ - - - 62 Fagaceae

11. Fruit a syncarp or syconium, - - - $\quad 55$ Artocarpaceae

12. Ovary superior or partly inferior, - - - - - - - 13

12. Ovary inferior, - - - - - - - - - - - 33

13. Style and stigma $1,-$ - $_{-}-$- $_{-}-\mathrm{-}^{-} 14$

13. Styles or stigmas 2-several, - - - - - - - -17

14. Leaves pinnately-parted; shrubs or trees, - _ - 121 Proteaceae

14. Leaves entire or lobed, - - - - _ - - - - 15

15. Herbs or shrubs; flowers often bracted; fruit an achene, 62 Allionaceae

15. Herbs, sometimes shrubby, flowers without bracts; fruit an

achene, - - - - - - - - 53 Urticaceae

15. Shrubs or trees; flowers without bracts; fruit a drupe, - $\quad-\quad 16$

16. Anthers opening by slits; leaves silvery below, - - 122 Eleagnaceae

16. Anthers opening by valves, - - - - - -123 Lauraceae

17. Ovary 1-celled, - - - - - - - - - - 18

17. Ovary with two-several cells or placentae, more than 1 ovuled, - $\quad$ - 27

18. Leaves with sheathing stipules, or if without stipules fruit a 3 -angled achene, - - - - - - - - 57 Polygonaceae

18. Leaves without stipules, or stipules not sheathing, and fruit not

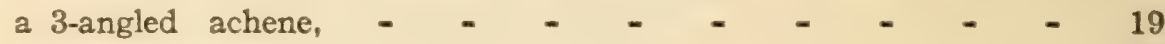

19. Shrubs or trees, - - - - - - - - - - 20

19. Herbs, sometimes shrubby, or vines, - - - - - - 21

20. Anthers opening lengthwise, - - - - - - - 56 Ulmaceae

20. Anthers opening by valves, - - - - - - 123 Lauraceae

21. Leaves compound; chiefly vines, - - _ - 69 Ranunculaceae

21. Leaves simple, 3-7 lobed; twining herbs, - - - 54 Cannabinaceae

21. Leaves simple; no vines and not twining, - _ - _ - 22

22. Plants without acrid or milky juice, - - - - - - - 23

22. Plants with acrid, often milky, juice, - - - - 101 Euphorbiaceae

23. Fruit a capsule with valvular dehiscence, - $\quad 64$ Tetragoniaceae

23. Fruit a utricle, berry, or achene, - - - - - - - 24

24. Stipules wanting, - - - - - - - - - - - 25

24. Stipules present, - - - - - - - -60 Corrigiolaceae

25. Flowers without scarious bracts, - - - - - - - 26

25. Flowers with scarious, of ten colored, bracts, - - 59 Amaranthaceae

26. Fruit a utricle or an achene, - - _ - - 58 Chenopodiaceae

26. Fruit a berry, - - - - - - - - 61 Phytolaccaceae

27. Stamens hypogynous, - - $\quad$ - - - - - -28

27. Stamens perigynous or epigynous, - - - - - - - 32

28. Herbs, rarely shrubs or trees, - - - - - - - - 29

28. Shrubs or trees, - - - - - - - - 141 Oleaceae

29. Flowers monœcious or diøecious, - - - 101 Euphorbiaceae

29. Flowers perfect, - - - - - - - - - - 30

30. Stamens tetradynamous, ovary 2-celled, - - - - 76 Brassicaceae

30. Stamens not tetradynamous, ovary several-celled, - - _ - - 31 
31. Fruit a capsule opening by valves,

31. Fruit a capsule opening at the top. - . -

66 Alsinaceae

31. Fruit a berry,

Fruit a samara; trees, - - - - - - - 107 Aceraceae

32. Fruit a berry, sometimes with scant pulp: flowers small; vines, $\mathbf{1 1 0}$ Vitaceae

32. Fruit fleshy, berry-like; flowers showy; vines, - _ - 118 Passifloraceae

32. Fruit a capsule, - _ _ - _ _ - - 64 Tetragonaceae

33. Shrubs or trees, dicecious, - - - - - 131 Nyssaceae

33. Herbs or shrubs with flowers in small involucrate heads $\mathbf{1 7 2}$ Ambrosiaceae

33. Plants with flowers perfect, - - - - - - - - 34

34. Fruit a capsule, - - - - - - - - - - 35

34. Fruit a berry, or a drupe, or dehiscent, - - - - - - 36

35. Calyz 4-lobed, herbs - - - - - - 129 Epilobiaceae

35. Calyx corolla-like, herbs or woody vines with flowers variously inflated.

35. Calyx margined, herbs sometimes shrubby, - - 64 Tetragoniaceae

36. Aquatic herbs; fruit bony, splitting into 2 or 4 nutlets. - 130 Gunneraceae

36. Herbs or trees; fruit dehiscent or a berry, - _ - - 127 Myrtaceae

37. Carpels one, or more than one and distinct or united only at the

base (ovary simple or multiple, apocarpous) - _ - - 38

37 Carpels more than one and united (ovary compound, syncorpous) $\quad$ - 47

38. Stamens hypogynous, - - - - - - - - - - 39

38. Stamens perigynous or epigynous, - - - - - - - 45

39. Flowers in corymbose panicles; shrubs or small trees, - 98 Rutaceae

39. Flowers monocious, in heads; trees, - _ - 86 Platanaceae

39. Flowers not monoecious, - _ - - - - - - 40

40. Saprophytes or root-parasites, - _ _ _ - 134 Monotropaceae

40. Succulent herbs, not parasitic, - _ - _ - - 80 Sedaceae

40. Waterplants with floating peltate leaves, - _ - _ _ - - 41

40. Plants different from the preceding ones, - . . . . - 42

41. Sepals and petals 3 each, stamens 3-18, - _ - 72 Cabombaceae

41. Sepals, petals and stamens numerous, - - 73 Nelumbonaceae

12. Flowers papilionaceous; fruit a legume or loment, - - 93 Fabaceae

42. Flowers not papilionaceous, - - - - - - - - - 43

43. Shrubs, sines or trees, evergreen or deciduous, fruit a follicu-

lar cone, - - - - - - - - 71 Magnoliaceae

43. Herbs, shrubs or small trees, deciduous, fruit a legume, berry

or capsule, - - - - - - - - - - - 44

44. Sepals 3, petals 6, stamens numerous, fruit berry-like, - 70 Anonaceae

44. Sepals and petals 5 each, stamens 5 or 10, fruit a legume, - 92 Cassiaceae

14. Sepals, petals and stamens numerous, fruit a capsule, - 88 Calycanthaceae

45. Leaves opposite, simple, without stipules, - $\quad 82$ Escalloniaceae

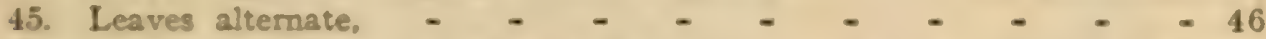

46. Leaves simple, without stipules, styles 2, - - - - 84 Iteaceae

46. Leaves simple. stipuies deciduous, style 1. - - - 90 Amygdalaceae

46. Leaves comprund, or at least lobed, with stipules, - -87 Rosaceae

47. Ovary superior, - - - - - - - - - - 48

47. Ovary inferior. - - - - - - - - - - 71

49. Stamens hypogynous, - - - - - - - - - 49

45. Stamens perigynous or epigynous, - _ _ - _ - - 63

49. Stamens more than twice the number of petals, - - - 50

49. Stamens more than petals, sumetimes twice the number. - - 55 
49. Stamens as many as the petals and opposite them, - - $\quad 59$

49. Stamens as many as the petals and alternate with them, - - 61

49. Stamens reduced in number to less than that of sepals or petals; ovary 1-celled, fruit a capsule, - _ - - - -66 Alsinaceae

49. Stamens reduced to 2 , sepals and petals 4; ovary 2-celled;

fruit a silique or silicle, _ - _ _ - 76 Brassicaceae

50. Calyx caducous, - - - - - - $\quad$ - 75 Papaveraceae

50. Calyx persistent, - - - - - - - - - - 51

51. Stamens monadelphous, - - - - - - - - 52

51. Stamens commonly collected into 3 or 5 groups, - 113 Hypericaceae

51. Stamens distinct, - - - - - - - - - -53

52. Anthers 1-celled, - - - - - - - - 111 Malvaceae

52. Anthers 2-3 celled, - - _ - - _ - - 112 Sterculiaceae

53. Style absent or nearly so, stigma 3-lobed, - $\quad 116$ Cistaceae

53. Styles united into a peltate structure, - - - 79 Sarraceniaceae

53. Styles and stigmas united into a disk, - - - 74 Nymphaeaceae

53. Styles more or less united, or distinct, - + - _ - - 54

54. Ovary 1-celled, - - - - - - - - 113 Hypericaceae

54. Ovary 3-5 celled, - - - - - - - - 114 Theaceae

55. Ovary 1-celled, - - - - - - - - - - 56

55. Ovary 2-celled; flowers seemingly papilionaceous, - 100 Polygalacea

55. Ovary 2-celled or falsely several-celled, flowers cruciferous, 76 Brassicaceae

55. Ovary 3-celled; sepals and petals 5 ; stamens 9 in groups of 3 ;

styles distinct; herbs, - - _ - - - 113 Hypericaceae

55. Ovary 3-celled; sepals and petals 5 ; stamens 8 ; style 1 with 3

stigmas; herbs, cultivated, - - - - - 94 Geraniaceae

55. Ovary 5-celled, - - - - - - - - - - 58

55. Ovary 6-7 celled; sepals and petals 6-7; stamens 12-14, 135 Ericaceae

56. Style obsolete or short, stigma entire or 3-lobed, - - 116 Cistaceae

56. Styles present, - - - - - - - - - - - 57

57. Sepals 2, petals 4-6, stamens 8-many, styles 3-8, - - 65 Portulacaceae

57. Sepals and petals 4-5, white; stamens 10 or less, styles 3-5, 66 Alsinaceae

57. Sepals and petals 5, yellow; stamens 5-20, styles 3, - 113 Hypericaceae

58. Stamens distinct, styles united into a beak, - _ - 94 Geraniaceae

58. Stamens united below into 2 sets, styles distinct, - - 97 Oxalidaceae

59. Flowers monœcious, - - - - - - 101 Euphorbiaceae

59. Flowers perfect, - - - - - - - - - - 60

60. Ovary 1-celled, 3 carpeled, - - - - _ - 63 Basellaceae

60. Ovary 1-celled, 5 carpeled, - _ _ _ _ - 137 Armeriaceae

60. Ovary 2-celled, flowers cruciferious, - - - - 76 Brassicaceae

61. Ovary 1-celled, - - - - - - _ - - 62

61. Ovary 2-3 celled, sepals and petals 4-5, - - - 98 Rutaceae

61. Ovary 5-celled; one of the sepals spurred, - $\quad 95$ Balsaminaceae

61. Ovary 5- or rarely 2 -celled, each cavity with a false partition;

sepals and petals 5; no spur, - $\quad$ - $\quad$ - 96 Linnaceae

62. Style obsolete or short, - - _ - - - - 116 Cistaceae

62. Style 1, ovary with 3 parietal placentae, stigmas 1 or $3, \quad-\quad 83$ Pittosporaceae

62. Style 1, one of the petals spurred, two of the stamens appendaged, 117 Violaceae

62. Styles 2-5, flowers white or pink, - - - - - 78 Droseraceae

62. Styles 3, flowers yellow, - - - - - - 115 Tumeraceae

63. Stamens and petals 2 , flowers dicecious, axillary; erect, evergreen, aromatic shrubs,

103 Empetraceae 
63. Stamens as many as the petals, monadelphous, adhering to the stalk of the 1-celled ovary; chiefly climbers or trailers, 118 Passiforaceae

63. Stamens as many as the petals and opposite them. - _ - 64

63. Stamens as many as the petals and alternate with them, or more, - 65

64. Sepals minute, ovary 2-6 celled, - _ _ - - 110 Vitaceae

64. Sepals manifest, ovary 3-celled, - _ _ - 109 Frangulaceae

65. Stamens twice or more than twice the number of petals, - - - 66

65. Stamens as many as or more than the petals, - _ _ - - $\quad 69$

65. Stamens of the same number as the petals, shrubs or trees, - _ - 70

66. Erect herbs, - - - - - - - - - - 67

66. Shrubs, trees or climbing herbs, - - _ _ - - $~ 68$

67. Petals 4-7, stamens 8-20, ovary 1-celled; cultivated plants, - 77 Resedaceae

67. Petals 4, stamens 8, ovary 4-celled, styles united, - 124 Melastomaceae

67. Petals 5, stamens 10, ovary 1-celled, styles 3-5, - 67 Caryophyllaceae

68. Calyx cup-shaped, petals 4-8, stamens 20-60, ovary several-celled, styles united, - - - - - - - - 98 Rutaceae

68. Sepals $4-5$ in two rows, petals $4-5$, stamens $8-10$, ovary $2-4$ celled, styles partially united, - _ _ _ _ - 108 Sapindaceae

68. Sepals and petals $3-5$; stamens $8-10$ united into a tube, ovary 3-5 celled, styles united, - _ _ _ _ _ 99 Meliaceae

69. Sepals 5 , petals $4-5$, stamens $5-8$, ovary 3 -celled, style slender, - - - - - _ _ - 106 Aesculaceae

69. Sepals and petals $4-7$, stamens 4 -numerous, often in rows, ovary 1-6 celled, style filiform, - _ - - 125 Lythraceae

70. Leaves pinnately compound; sepals, petals and stamens each 4-6; ovary 1-celled, fruit a drupe or berry, - _ _ 104 Spondiaceae

70. Leaves lobed or palmately compound; sepals, petals and stamens each 4-9; ovary 2-celled, fruit a samara, - _ - 107 Aceracere

71. Stamens more than twice the number of petals, - $\quad$ - $-\quad-72$

71. Stamens not more than twice the number of petals, - $-{ }_{-}-76$

72. Maritime shrubs or trees, - - - - - - 128 Rhizophoraceae

72. Fresh-water plants, - - - - - - - 74 Nymphreaceae

72. Landplants, - - - - - - - - - - 73

73. Styles distinct, - - - - - - - - 89 Malaceae

73. Styles united, - - - - - - - - - - 74

74. Vines, shrubs or trees, - - - - - - - - - 75

74. Succulent herbs, sometimes shrubby; flowers monocious; leaves usually obliquely ovate or teniform. - _ - - 120 Begoniaceae

74. Succulent plants without leaves, - $\quad$ - $\quad$ - 119 Opuntiacea 75. Vines and erect shrubs, flowers white, fruit a capsule, - 82 Escalloniaceae 75. Shrubs and small trees, flowers scarlet, fruit a berry, - 126 Punicaceae

75. Shrubs and small trees, flowers white, fruit a berry;-or tall trees with fruit a capsule.

127 Myrtaceae

76. Styles wanting. stigmas 1-4; decumbent aquatic herbs, 130 Gunneraceae

76. Styles distinct, - - - - - - - - - - - 77

76. Styles united, or style single, rarely wanting, - - - - - 80

77. Flowers not in umbels, - _ - _ - _ _ - - 78

77. Flowers in umbels, - - _ - - - - - - - 79

78. Herbs; sepals 2, deciduous; ovary 1-celled, styles 2-8, - 65 Portulacacene

78. Shrubs or trees; calyx $4-5$ lobed to truncate; ovary 2-4 celled:

styles 2-4, sometimes slightly united, - - $\quad 82$ Escalloniacene

79. Hetbs; styles 2 ; fruit dry, of two united carpels, - - 133 Ammincene 
79. Herbs; styles $2-3$ or 5 ; fruit a berry or drupe, - _ 132 Hederaceae

80. Herbs, rarely shrubby; ovary 1-6 celled, fruit a capsule, - 129 Epilobiaceae

80. Herbs; flowers in umbels; fruit of two united carpels, - 133 Ammiaceae

80. Herbs, trailing or climbing by tendrils; fruit a pepo, - 169 Cucurbitaceae

80. Vines, evergreen; flowers 5-parted; fruit berry-like, - $\quad 132$ Hederaceae

80. Shrubs or trees; flowers 4-5 parted; ovary 1-4 celled, - _ _ 81

81. Petals strongly concave, hooded; ovary 3, rarely 2-celled, 109 Frangulaceae

81. Petals not hooded; ovary 1-2, rarely 3-celled, - - 131 Nyssaceae

82. Ovaries 2; styles 2, distinct, - - - - - 147 Dichondraceae

82. Ovary free from the calyx, superior or nearly so, - _ $\quad$ - 83

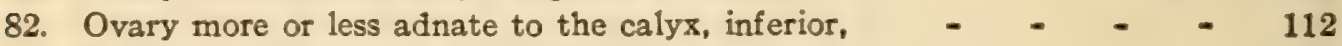

83. Stamens free from the corolla, - - - - - - - - -84

83. Stamens more or less adnate to the corolla, - _ _ _ _ 87

84. Ovary simple, 1-celled, sometimes several-celled by cross-partitions, - 85

84. Ovary compound, - $\quad$ - $\quad$ - $\quad$ - $\quad$ - $\quad 86$

85. Corolla regular of 3-6 partially united petals, - - 91 Mimosaceae

85. Corolla papilionaceous, two of the petals united or cohering, 93 Fabaceae

86. Ovary 1-celled, styles filiform; stamens 5, distinct, - - 137 Armeriaceae

86. Ovary 2-celled, styles united; stamens 8 or 6 in 1 or 2 sets, - 100 Polygalaceae

86. Ovary 2-6 celled, styles short or wanting, stigma lobed; stamens

4-6, distinct, - - - - - - - 105 Aquifoliaceae

86. Ovary 2-7 celled, styles united, stamens 4-12, distinct, - 135 Ericaceae

87. Stamens as many as the lobes of the corolla and opposite them,

-or twice as many, -or more, - - - - - - - 88

87. Stamens as many as the lobes of the corolla and alternate with
them, - or fewer, -

88. Ovary 1-celled; stamens and corolla-lobes 5, - - - - $\quad-89$

88. Ovary 2-celled; stamens 6 or 8 in 1 or 2 sets, - _ $\quad 100$ Polygalaceae

88. Ovary several celled or consisting of as many carpels as there

are sepals, either distinct or partially united,-or fewer, - _ - 90

89. Shrubs or acaulescent herbs, - - $\quad-\quad$ - 137 Armeriaceae

89. Caulescent herbs, - - _ - $\quad$ - $\quad$ - 138 Primulaceae

90. Stamens several, monadelphous, - _ - - - 111 Malvaceae

90. Stamens united into 5 groups, - - - - - - 114 Theaceae

90. Stamens not monadelphous and not in 5 groups, - - - - 91

91. Herbs; calyx and corolla 4-lobed, stamens 8, - - - 80 Sedaceae

91. Shrubs or trees, - _ - - - _ - - - - 92

92. Flowers perfect; corolla 4-7 lobed, stamens 4-14, - _ $\quad$ - 135 Ericaceae

92. Flowers perfect; corolla 4-several lobed, stamens alternating with

staminodia, - - - - - - - - 140 Sapotaceae

92. Flowers dicecious; corolla 3-7 lobed, stamens 4-16 or more, 139 Ebenaceae 93. Evergreen shrubs or trees, - - - - - - - - 94

93. No evergreens, or evergreen climbers and trailers, - $\quad-\quad-\quad 96$

94. Flowers regular, - - - - - - - - - - - 95

94. Flowers irregular, - _ _ _ _ - _ - 162 Bignoniaceae 95. Stamens 2, - - - - - - - - - 141 Oleaceae

95. Stamens 4-6, flowers small, - _ _ - _ 105 Aquifoliaceae

95. Stamens 5, flowers of medium size, ovary 1-2 celled, - 145 Apocynaceae

95. Stamens 5, flowers of medium size, ovary 4-celled, 154 Ehretiaceae

96. Aquatic herbs with broad floating leaf-blades on long petioles, $\mathbf{1 4 4}$ Menyanthaceae

96. Herbaceous parasites, leaves reduced to scales, - $-\quad-\quad-\quad-97$

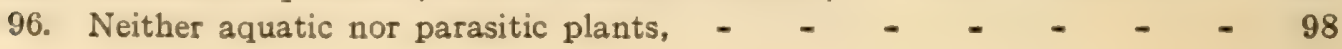


97. Twining herbs; flowers in cymes, white; corolla $4-5$ lobed, 149 Cuscutaceae

97. Herbs not twining; flowers in spikes, pale yellow; corolla 2

lipped, - _ - _ _ _ - - 162 Orobranchaceae

85. Corolla 2-lipped, -or corolla-lobes somewhat unequal, _ _ _ $\quad$ - 99

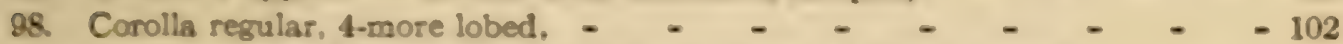

99. Stamens 2, ovary 1-celled, stigma 2-lipped, corolla spurred. - - - - . - .

160 Pinguiculaceae

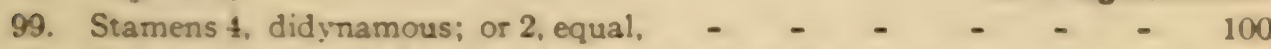

99. Stamens 5, often 1-3 reduced to sterile filaments, or absent, - 101

100. Ovary 2-celled, style terminal; stems enlarged at the jointed nodes,

159 Acanthaceae

100. Ovary +celled, deeply 4-lobed, style central; stems 4-sided, - 157 Lamiaceae

100. Ovary 2 or 4 -celled, style terminal; stems commonly 4 -angled.

101. Calyx 2-lipped or truncate, - _ _ _ 162 Bignoniaceae

101. Calyz of $4-5$ more or less united sepals; corolla imbricated

in the bud, - - _ - _ - 158 Rhinanthaceae

101. Calys of 5 more or less united sepals; corolla convolute in the bud,

102. Stamens fewer than corolla-lobes, - _ - _ -

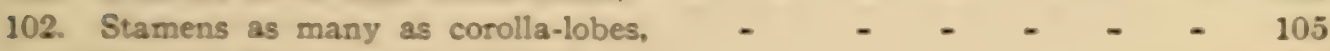

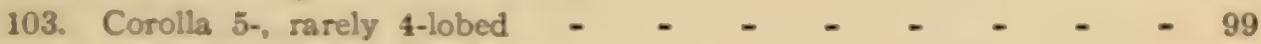

103. Corolla 4-, rarely 5-lobed, - - - - _ - - 104

104. Shrubs or trees, - _ _ _ - -

104. Herbs, - - _ - _ _ - - 163 Plantaginaceae

105. Perennial herbs or shrubby plants growing in and about

swamps, - $\quad$ - $\quad-\quad$ - $\quad$ - 150 Hydroleaceae

105. No such swamp-plants, - _ - _ - - - - 106

106. Plants with stems prostrate or twining, leaves alternate; calyx, corolla and stamens each 5; ovary 2-5 celled with 1-2 ovules

in each cavity; fruit a capsule, - _ _ - 148 Convolvulaceae

106. Plants with altemate leaves; calyx, corolla and stamens each $4-6$,

ovary $2-6$ celled, - - - - - - - -

106. Plants with leaves chiefly basal; calyx and corolla each 4 -lobed, membranous; stamens 4 or 2; ovary 1-2-or 3-4-celled, flowers

in terminal spikes on scapes, _ _ _ _ 163 Plantaginaceae

106. Plants different from the preceding ones, - _ - - - 108

107. Orules $1-2$ in each cell; fruit a drupe; shrubs or trees, 105 Aquifoliaceae

107. Ovuies numerous; fruit a berry or a capsule; herbs, vines or shrubs,

108. Ovary 1-celled; calyx, comilla and stamens each 4-12; leaves opposite, of alternate and scaly; fruit a capsule. - - 143 Gentianaceae

108. Ovary 2 or 4-celled, - _ _ _ _ _ _ _ _ - 109

108. Ovary 3-celied; calyx, corolla and stamens each 5; leaves altemate

or opposite; fruit a capsule, - _ _ _ _ 151 Polemoniaceae

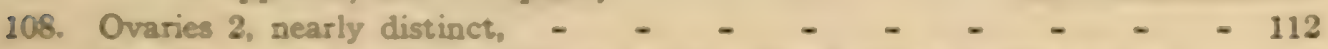

1us. Ovanes 4 , more or less cohering; calyx, corolla and stamens each

5; leaves altemate; frut of $\$$ nutlets distinct or cohering.

153 Borraginaceae

109. Ovary 2-celled; stamens 2 or 4 ; fruit a capsule, samara, berry

or drupe,

109. Ovary 2-ceiled; stamens $\mathbf{4 - 5}$, fruit a capsule, -

141 Oleacea 0

142 Spigeliaceae 
109. Ovary 2-4 celled, fruit a drupe or of 2 or 4 nutlets, _ _ 110 110. Stamens 2 or 4 , - - - - - - - - 156 Verbenaceae 110. Stamens 5 ; styles or stigmas with a glandular ring; mainly herbs

155 Heliotropaceae

111. Styles united, stamens distinct, fruit of two follicles or a drupe, - - - - - - - - 145 Apocynaceae

111. Styles only united above, stamens mostly united; flowers in umbels with a crown between corolla and stamens adnate to either or to both; fruit of 2 several-seeded follicles, 146 Asclepiadaceae

112. Succulent trailing or climbing herbs with alternate leaves; flowers monœcious or diocious; calyx and corolla each 5, stamens mostly 3, ovary 1-3 celled, fruit a pepo, - - - 169 Cucurbitaceae

112. Herbs, sometimes fleshy; stems erect or climbing; leaves opposite and at the base whorled; flowers usually perfect; calyx lobed or bristly; corolla 5-lobed; stamens 3 ; ovary $1-3$ celled; fruit an achene, - _ - _ - _ _ - 167 Valerianaceae

112. Green parasitic shrubs, flowers monœcious or diœcious; corolla and stamens each 2-6, ovary 1-celled, fruit a berry, - 164 Loranthaceae

112. Plants unlike the preceding ones, - - - _ - - - 113 113. Flowers not in involucrate heads, - - - - - - 114 113. Flowers in involucrate heads (Compositae), - - - 118

114. Stamens free from the corolla, or slightly adnate to the base, - - $\quad \mathbf{1 1 5}$

114. Stamens more or less adnate to the corolla, - - - - _ - -117 115. Herbs; stamens as many as the sepals, - - - - - 116

115. Shrubs or small trees, stamens twice as many as the sepals,

136 Vacciniaceae

116. Corolla 5-lobed, ovary 3-5 celled, - _ - _ - 170 Campanulaceae

116. Corolla bilabiate or irregular, the tube split to the base on one side, ovary generally 2-celled,

171 Lobeliaceae

117. Herbs, shrubs or trees, with stipules adnate to the stems between the leaf-bases; corolla and stamens each 3-6, rarely 10, 165 Rubiaceae

117. Shrubs, vines or trees, without stipules, or with stipules adnate to the petiole; corolla and stamens each $4-5$; anthers versatile.

166 Caprifoliaceae

118. Heads inconspicuous, with white or greenish disks; stamens 5 ,

distinct, the anthers converging about the stigma, 172 Ambrosiaceae

118. Heads composed of only tubular florets, or the outer ones ligulate; stamens 5 , the anthers united into a ring, - - 173 Carduaceae

118. Heads composed of only ligulate florets; stamens 5 , the anthers connate around the style, - - - 174 Cichoriaceae 


\title{
KEY TO THE GENERA AND SPECIES.
}

\author{
Pteridophyta (Ferns and Fern Allies).
}

\section{Ophioglossaceae, Adder's Tongue Family.}

Succulent plants from a fleshy rootstock, stem with one leaf, sporophyl a spike or a panicle, sporanges naked, spores of one kind, yellow.

1. Leaf with reticulate veins, sporanges in 1-several simple spikes, - - $\quad 2$

1. Leaf with free veins, sporanges in panicled spikes, - Botrychium, Moonwor

B. obliquum (B. tematum). Stalked leaf near the base of the stem, ternate or 2-pinnate; sporophyl long-stalked, $2-4$ pinnate. Low shady woods.

B. tenuifolium. Leafstalk very slender, blade bi-ternate; sporophyl a slender stalked panicle. Low grounds.

B. Virginianum, Rattlesnake Fern. Slender fleshy stem, with ternate leaf sessile above its middle; sporophyl long stalked and recurved. Woods.

2. Leaf simple and entire; sporophyl terminal bearing two rows of large cohering sporanges; terrestrial plants, - - Ophioglossum, Adder's Tongue.

O. vulgatum. Stem slender and tall with the obtuse leaf sessile near its raiddle. Low grounds.

O. pusillum (audicaule). Stem short with the ovate leaf near its base, the blade narrowed into a short petiole. Sandy soil.

2. Leaf palmately lobed; sporophyls several near the base of the leaf; epiphytic plants on palmettos. - - - - - - - - Cheiroglossa

C. palmata. Leaf 1-9 lobed, spikes 1-16. Hammocks.

\section{Osmundaceae, Flowering Fern Frmily.}

Large plants with stout rootstocks; leaves coiled in vernation, veins free, running to the margins; large globular sporanges on modified contracted leaflets, or in sori on their lower surfaces.

The spore-bearing fronds much contracted with the sporanges on the margins of the divisions, veins forked, spores green. - _ _ Osmunda

O. spectabilis (regalis), Royal Fern. Leaves clustered from one rootstisk. tall, with 2-pinnate leaves that are fertile at the top: sp srophy is panicied, at first greenish but later dark-brown. Swampy places. 
O. cinnamomea, Cinnamon Fern. Cluster of erect sterile leaves with few fertile ones from the creeping rootstock; petioles tomentose when young; leaflets pinnatifid; sporophyl 2-pinnate; sporanges cinnamon-colored; the fertile leaves wither before the sterile ones expand. Some fronds are partly sterile and partly fertile. Low wet places.

\section{Polypodiaceae, Fern Family.}

Leaves coiled in vernation; sporanges in sori on the back or along the margin of the blades, and provided with an annulus.

1. Sori without indusia, - - - - - - - - - - 2

1. Sori with indusia, - $\quad$ - $\quad$ - $\quad$ - $\quad$ - 4

2. Sori in masses covering the under surface of the leaf-blades partly or totally,

A. aureum. Tall swamp-plants with erect massed rootstocks and tufted leaves, 1-2 m. long; petioles erect, angular grooved; blades leathery, glossy, 3-4 dm. wide; leaflets about 12 pairs; areolae without free veinlets, oblique to. the margin; sori covering part of the leaves. Green Springs, near Enterprise, and South.

A. lomarioides. Leaflets about 24 pairs; areolae facing the margin; sori covering the whole leaves. Ponds and wet ground.

2. Sori roundish,

2. Sori linear, more than twice as long as broad, _ _ _ _ _ Vittaria

V. lineata, Grass Fern. Leaves grass-like; sori in a continuous groove near the margin of the blade; veins obscure. On palmetto.

3. Veins free, - _ _ _ - _ _ _ - Polypodium P. polypodioides (incanum), Resurrection Fern. Leaves coriaceous, pinnately parted, small; petioles and back of blades with peltate scales; veins obscure. An evergreen on rocks and trunks of trees, especially oaks.

P. pectinatum. Leaves about $1 \mathrm{~m}$. long, deeply pinnatifid, without scales; veins 2-3 forked, pellucid. On trees.

P. plumula. Leaves about $5 \mathrm{dm}$. long, petioles black, blades without scales; veins 1 -forked, obscure. Hammocks.

3. Veins anastomosing, forming areolae which include free veinlets, at the end of which the sori appear. - _ - - Phlebodium

P. (Polypodium) aureum. Petioles chestnut-colored, blades ample, cut nearly to the rachis; segments entire, undulate. On palmetto and cultivated in pots.

4. Indusia formed by the margin of the leaf-blade, - - - - - -5

4. Indusia specially developed, sori dorsal, - - - - - - -7

5. Sporanges in intramarginal lines which connect the ends of the veins, - $\quad 6$

5. Sporanges in reflexed portions of the leaf-blades at the ends of the veins, - - - - - - - - - Adianthum

A. Capillus-Veneris, Venus-hair. Petioles slender and shining; leaves ovatelanceolate, 1-2 pinnate. On limestone and cultivated.

A. tenerum, Maidenhair. Petioles slender and shining; leaves deltoid; 3-4 pinnate. In lime-sinks.

Several species of Adianthum are cultivated as A. cuneatum, A. hispidulum, A. hybridum, A. farleyense, A. caudatum, A. lunulatum; the latter two are "walking ferns."

6. Indusium single,

Pteris 
P. Cretica. Leaves ternate or pinnate, smooth, ovate. Shady woods.

6. Indusium double, - - - _ - _ - - - Pteridium

P. aquilinum (Pteris aquilina), Bracken or Brake Blades large, ternate, the three divisions each bi-pinnate, the terminate pinnules often elongated. In sunny places.

A cultivated variety of Pteris is the beautifully striped albolineata; other species of the greenhouse are P. serrulata, P. tremula, etc.

7. Sori linear, more than twice as long as broad, - - - - - - 8

7. Sori roundish, - - - - - - - - - - 11

8. Sori parallel to the midrib, - _ - _ _ _ - - - 0

8. Sori oblique to the midrib, - - - - - - $\quad$ - Asplenium, Spleenwort

a. Blades pinnate, sori straight, - _ _ _ _ _ _ _ b

a. Blades 2-pinnate, sori curved. A. Filix foemina, Lody-fern. In low shady woods.

b. Rachis brown or black, leaflets auricled, - - _ - - - c

b. Rachis green, leaflets crenate, - - - A. dentatum. In sandy soil

c. Leaflets mostly opposite, - - A. resiliens (parvulum). On limestone

c. Leaflets mostly altemate. - A. platyneuron (ebeneum). On shady rocks

9. Veins free, sori more or less continuous, _ _ _ _ _ Blechnum

B. serrulatum (angustifolium). Petioles rigid; leaves long and leathery, with 12-24 pairs of leaflets, the fertile leaves narrower than the sterile ones. Coarse swamp-ferns.

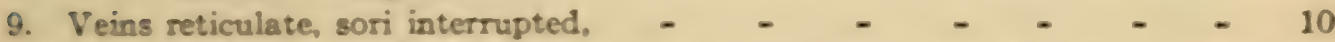

10. Leaves of the same kind, - _ _ _ _ _ _ - Anchistea

A. (Woodwardia) Virginica. Petioles stout, darker below; blades pinnate, leathery; veins reticulate along the midrib, free toward the margin. In swamps and shallow ponds.

10. Leaves of two kinds, - - - - - - - - Lorinseria

L. areolata (Woodwardia angustifolia). Pertile blades on longer petioles than the sterile ones; the segments of the latter making a broader wing along the rachis than those of the former. In swamps and low grounds.

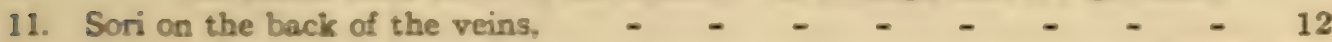

11. Sori at the ends of free veins, _ _ _ _ _ - Nephrolepis

Nephrolepis with long pendent or spreading blades and numerous leaflets is an epiphytic genus from South Florida, but has several cultivated species, as N. Davallioides furcans (Boslon Sloghorn), N . exaltata (Swordfern), with the varieties Bostonensis (Boston Fern), and cristata (Cresled Boslon Fern), N. rufescens tripinnatifida (Ostrich Feather), etc. The true Slaghorn-ferns belong to the genus Platycerium.

12. Indusium orticular and peltate, fixed by the center; veins free, Polystichum P. (Aspidium) acrostichoides, Christmas Fern. Petioles very chaffy; blades pinnate, leaflets with spiny teeth; sori copious. In rocky woods. The P. capense is a cultivated species, while Cyrtomium falcatum, Holly Farm, single or crested, is closely related.

12. Indusium cordate-reniform, fixed at the sinus, - - Dryopteris, Shield Fern

D. (Aspidium) Tbelypteris. Rootstock slender; blades thin, scarcely narrowed at the base, leaftets deeply pinnatifid, margin of fertile segments strongly revolute, veins forked; sori crowded. In swamps.

D. (Aspidium) patens. Rootstock stout; blades long, thin, pubescent beneath. leaflets deeply pinnatifid, veins simple; sori near the margia, indusia small, pubescent. In sbady woods. 
D. (Aspidium) Floridana. Rootstock thick, scaly; blades firm, veins forked; upper leaflets fertile, deeply cut into oblong segments; lower leaflets sterile, broader, less deeply cut; indusia large, thin. On low grounds.

D. (Aspidium) unita. Rootstock creeping, slender; blades pinnate, long, firm, with the pinnae pinnatifid-lobed; lower veins of contiguous lobes united. Moist thickets.

Aspidium tsussimense is a dwarf fern cultivated in fern dishes, - Other cultivated ferns are the Gold- and Silver-ferns, Gymnogramma, named for the yellow or white wax-like powder that covers the under surface of the leaves; the Tree-ferns, Cyatheaceae; some with the sori at the end of the veins, Cibotium, of which C. schiedei has a caudex and C. barometz has not; some with the sori on the back or in the axils of the veins, of which Alsophila australis, Australian Tree-fern is the type;-the Climbing ferns, Lygodium, of which L. scandens is best known.

\section{Lycopodiaceae, Club-moss Family.}

Moss-like plants with mostly creeping stems and narrow leaves in 2-several rows; sporanges in the axils of the bracts forming compact cones.

Leaves in 4 or more rows; spores sulphur-yellow; in our species the cones

terminal. In sandy bogs or on low pine-land, - Lycopodium Club.Moss.

1. Sporanges globular, leaves and bracts alike, - - - - - - 2

1. Sporanges compressed, leaves and bracts unlike, - - - - - 4

2. Bracts slightly toothed at the base, - - _ _ - - L. Chapmani

2. Bracts twice as long and much toothed at the base, - _ _ - - - - 3

3. Stems arching, leaves in many rows, spreading, hairy; bracts not hairy, - $\quad$ - $\quad$ - _ - - L. alopecuroides

3. Stems prostrate, leaves in one plane, - - - - - L. pinnatum

4. Stems arching, leaves in 5 or more rows, cones numerous, nodding, L. cernuum

4. Stems prostrate, leaves nearly in one plane, - - _ - L. Carolinianum

\section{Psilotaceae, Psilotum Family.}

Slender plants with sporanges sessile in the axils of the leaves.

Psilotum nudum (triquetrum). Stems forking; triangular; leaves mere scales, alternate; sporanges spiked. In hammocks, sometimes epiphytic.

\section{Selaginellaceae, Selaginella Family.}

Moss-like plants with much branched stems, scalelike leaves, and one-celled sporanges arranged in fourangled, axillary spikes or cones.

1. Stem-leaves of two kinds in two planes,

1. Stem-leaves of the same kind, several-ranked,

2. Stems flaccid, creeping, pale green, - -

2. Stems rigid, ascending, dark green, - -

3. Stems creeping, rooting throughout,

3. Stems ascending or erect, slender,
S. apus. Low shady woods S. Ludoviciana. Shady ground S. rupestris. Pine barrens S. arenicola. Sandy fields 
Several species are cultivated as: S. Braunii and S. Vogelii both erect; S. cuspidata, tufted; S. uncinata, or Ruimbing-moss, creeping; S. hemaetodes with spreading, fern-like branches; etc., Selaginella lepidophylla, Bird's-nest muss with bright green stems crowded in rosettes. curling closely into a dull brown ball when dry, belungs to the so-called "Resurrection-plants."

\section{Isoetaceae, Quillwort Family.}

Aquatic plants with a cluster of awlshaped leaves from a short fleshy stem; "sporanges are sessile in the excavated bases of the leaves, the sides more or less covered with a fold of the inner side of the blades ("VELUM"); those of the outer leaves contain megaspores, those of the inner contain microspores. The only species found in lakes and clear streams of middle Florida is:

Isoetes flaccida, with leaves of about half a meter long; complete velum, oval sporanges covered with flat tubercles and light-colored megaspores.

With the genus Isoeles. Chapman's Flora unites the genus Arolla to form the Hydroplerides or Waler-fern Family. Small's Flora has the Azolla in the Salvinia Family.

Azolla Caroliniana; minute, reddish or green (according to the amount of sunlight), moss-like, floating plants with pendent roots, pinnately branched stems covered with imbricated 2-lobed leaves; spores of two kinds. On still water.

\section{Spermatophyta. Gymnospermae.}

\section{Cycadaceae, Cycas Family.}

Shrubs or trees with clustered pinnate leaves and diøcious flowers without perianth; flowers in small oblong or cylindric cones, scales peltate spirally arranged; sterile flowers consisting of 1-celled anthers, the fertile ones of nearly sessile ovules; seeds nut-like; cotyledons 2.

Low palm-like plants; leaves circinate in the bud, petinles often spiny, blades pinnate, segments jointed to the rachis, - - - Zamia, Coonlie or Complie

Z. Floridana, with leaf-segments $10-16$ veined. In the flatwoods.

Z. pumila, with leaf-segments $20-25$ veined. In the hammocks.

The Cycas revoluta (sis-called Sagu Palm) and Dion edule are cultivated specis.s.

9. Pinaceae (Coniferae), Pine Fumily.

Evergreen monnecious trees with rigid needle-like leaves; fruit a cone, formed by the accrescent scales of the pistillate aments; seeds at the base of each scale, often samara-like; cotyledons 2-16.

Staminate aments at the enls of bran:hes of the preceliag year. anthers 2 -celle 1 ; protiate amenos on the young 2 wigs, consos maturing the second year; seels with einglicl wings. - Pinus, Pine 
*1. Cones over $7 \mathrm{~cm}$. long,

1. Cones less long.

2. Cones $16-25 \mathrm{~cm}$; leaves 3 in a sheath, $20-40 \mathrm{~cm}$. long. In sandy soil, - - P. australis (palustrus), Long-leaved or Yellow Pine

2. Cones $8-14 \mathrm{~cm}$. long,

3. Cones flat or depressed at the base; leaves $2-3$ in a sheath, $18-30$ $\mathrm{cm}$. long; resembles the preceding, but smaller. In low sandy soil, - - - - P. Elliotti, Swamp Pine, Blue Pine

3. Cones rounded at the base; leaves 3 , rarely $2-4$, in a sheath, $15-28$ $\mathrm{cm}$. long; glaucous; bark very thick and furrowed. In sandy, mostly damp soil, _ - - P. Taeda, Loblolly or Old Field Pine

4. Cones ovoid, mostly opposite; leaves 3 in a sheath, 15-25 cm. long, glaucous; trunk with flaky bark and many short branches near the base. Border of ponds and swamps,

P. Serotina, Black or Pond Pine

4. Cones narrowly conical when closed; leaves 4-12 cm. long, - $\quad-5$

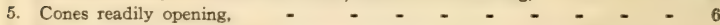

5. Cones $4.5-6 \mathrm{~cm}$, tardily opening or remaining closed; leaves 2 in a sheath, $4-8 \mathrm{~cm}$. long, very slender. On sandy ridges near the coast, - - - - - P. clausa, Sand Pine, Spruce Pine

6. Cones mainly less than $5 \mathrm{~cm}$. long; leaves 2 in a sheath, $4-8 \mathrm{~cm}$. long, very slender; trunk with relatively smooth bark and spreading branches near the ground. In the hammocks

P. glabra, Spruce Pine, Cedar Pine, White Pine

6. Cones mainly over $5 \mathrm{~cm}$. long; leaves $2-3$ in a sheath, $8-12 \mathrm{~cm}$. long, slender; trunk with furrowed and very rough bark without spreading branches near the ground. In sandy, rocky or clayey soil, - P. echinata (mitis), Short-leaved Pine, Yellow Pine

\section{Juniperaceae, Juniper Family.}

Shrubs or trees with scale-like or subulate leaves; flowers without perianth; aments mostly solitary; cotyledons 2-9.

1. Deciduous trees; leaves not scale-like; flowers monœcious; the sterile aments in a drooping panicled spike, the fertile aments subglobose, single or by pairs, sessile; cones globular, closed; seeds angled, wingless,

Taxodium, Cypress

T. distichum, Bald Cypress. Very tall tree; bark relatively thin and smooth, leaves 2-ranked, linear, spreading; knees conical. In swamps, but thrives also in dry soil cultivated.

F. imbricarium, Pond Cypress. Half as tall; bark thick and coarse, leaves appressed to the erect branchlets; knees short and rounded. In lakes and creeks, also in dry soil.

1. Evergreen shrubs and trees,

2. Flowers moncecious, sterile aments terminal, solitary, nearly sessile between the leaves; fertile aments solitary, terminal on short branchlets, oblong; cones oblong, drooping; seeds flat, broadly winged,

Thuja, Arbor Vitae

Thuja occidentalis and Thuja (Biota) orientalis, cultivated in varieties.

2. Flowers monœcious, sterile aments terminal, sessile or nearly so;

*See Glossary for measurements. 
fertile aments terminal, globose; cones woody, globose; carpellary scales peltate; seeds slightly winged or merely angled,

Chamaecyparis (Cupressus)

C. thyoides (sphaeroida), White Cedar, Cypress. Middle-sized, strongly scented tree; the scale-like leaves 4-ranked, imbricated; cones small; scales with points on the back, at length widely spreading. Wet sandy places towards the coast.

2. Flowers mostly dicecious; sterile aments very small, 3-6 together, terminal on the branchlets; fertile aments subglobose; cones berrylike, seeds wingless, - $\quad$ - $\quad$ - $\quad$ - Sabina or Juniperus

S. barbadensis, Southern Red Cedar. Shrub or small tree with reddish, odorous wood; cones small, blue, covered with a bloom. Low sandy places.

Among the cultivated Conifers are the Araucaria excelsa, Norfolk Island Pine in pots; for the open ground Araucaria Bidwillii, Bunya-Bunya Pine; several species of Cupressus or Cypress, and some of the Pines, as: Pinus excelsa or Botan Pine and P. Halepensis or Jerusalem Pine.

\section{Spermatophyta. Monocotyledones.}

\section{Typhaceae, Cat-tail Family.}

Marsh-herbs with simple stems; leaves sheathing at the base, linear; flowers monœcious in dense spikes, the staminate spikes above the pistillate.

Typha latifolia. Stems tall, leaves long; spikes dark brown with the fertile and sterile portions contiguous. Margins of rivers and ponds. Summer.

T. angustifolia. Stems tall, leaves long; spikes light brown with the fertile part separate from the sterile part. Marshes near the coast. Summer.

\section{Pandanaceae, Screw-pine Family.}

Mainly woody plants with stilt-like aerial roots and ong, sword-like, spiny leaves, spirally arranged; the diolious flowers are rarely produced in cultivation.

Pandanus utilis. Leaves green, erect, with red spines.

P. Veitchii. Leaves dark green in the center, margined with broad bands of white.

P. baptistii. Leaves with a creamy-yellow stripe down the center.

P. Sanderi. Leaves with narrow lengthwise bands of golden yellow.

13. Sparganiaceae, Bur-reed Family.

Aquatic herbs with erect or floating stems, leaves narrow, sheathing at the base; flowers monœcious in dense heads on the upper part of the stem and its branches, the staminate above the pistillate.

Sparganium androcladum. Leaves linear, glabrous; pistillate beads sessile 
or peduncled, finally twice as large as the staminate, together forming an interrupted spike. In shallow water. Summer.

\section{Zannichelliaceae, Pondweed Family.}

Submerged herbs with alternate or clustered leaves on slender stems; flowers perfect or monœecious in axillary spikes arising from a bract-like spathe; perianth wanting.

1. Leaves alternate, flowers perfect, stamens 2, pistils 4, - Ruppia, Ditch-grass

R. maritima. Leaves almost filiform. In brackish water. Summer.

1. Floating leaves smaller and thicker than submerged leaves; flowers perfect, stamens 4, pistils 4, - - - Potamogeton, Pondweed

P. Lonchitis (fluitans). Stems long, branched; submerged leaves large, lanceolate, pellucid; floating ones oblong, half as long as the submerged; stipules free from the leaves; peduncles short; spikes cylindric. In ponds and rivers. Summer.

P. diversifolius (hybridus). Stems very slender, branched; submerged leaves filiform, setaceous; floating ones elliptic, leathery; stipules adnate to the submerged leaves; peduncles short; spikes oblong. Shallow ponds. Summer.

\section{Alismaceae, Water-Plantain Family.}

Acaulescent marsh-herbs with sheathing leaves and mostly simple scapes, bearing the terminal racemes or panicles; calyx of 3 persistent sepals; corolla, white or pink, of 3 decidous petals; stamens 6-many; ovaries 1celled, each cell 1-ovuled; fruit a head of achenes.

1. Flowers perfect or polygamous; stamens $12-30$; fruit a bristly head.

Spring and Summer,

E. parvulus. Flowers in terminal umbelled clusters, leaves linear. Shallow ponds.

1. Flowers monœcious or diœcious in whorls of 3 near the top of the scape, the upper whorls staminate; stamens many, pistils many;

fruit a globular head. Summer and Fall. - - Sagittaria, Arrowheads

S. natans. Pedicels of fertile flowers thickened, reflexed at maturity; stamens 7 or 8 ; scapes simple, leaves elliptic, floating. Ponds.

S. graminea (simplex). Pedicels of fertile flowers slender; stamens 10-12, hairy; scapes slender; leaves linear. Ponds.

S. lancifolia (falcata). Pedicels of fertile flowers slender and shorter than those of sterile flowers; scapes tall, often branched; leaves elliptic, leathery. Lakes and marshes.

S. pubescens (variabilis). Pedicels of fertile flowers slender and half as long as those of sterile flowers; scapes sometimes pubescent; leaves mostly sagittate and often pubescent; whorls of inflorescence remote. Marshes.

16. Elodeacea, Tape-Grass Family.

Submerged herbs; perianth regular, 6 in two rows, 
the inner sometimes wanting; filaments of stamens distinct or monadelphous; ovary inferior, 1-celled.

1. Flowers dicecious; staminate numerous on a spadix enclosed in a spathe, stanens 1-3; pistillate flowers solitary subtended by a spathe,

V. spiralis, Eel-grass. Acaulescent; leaves lint-shaped, basal; fowers inconspicuous, the fertile ones borne on a long slender scape. which after fertilization coils spirally and submerges the flower. In slow-flowing water. Summer and Fall.

1. Flowers divecious or polygamous, from a spathe; stamens 9 in the sterile and $3-6$ in the fertile flowers, _ _ _ - Philotria (Elodea)

P. (E.) Canadensis, Water-thyme, Water-pest. Caulescent; leaves elliptic, opposite or whorled; flowers axillary, dioccious; sterile flowers submerged. "breaking off at maturity" and floating on the surface they discharge the pollen near the fertile flowers"; the fertile flowers floating, attached by slender stalks. In slow-flowing water. Spring to Fall.

\section{Hydrocharitaceae, Frog's-bit Family.}

Aquatic herbs, mostly in still water, with a white perianth of 3 or 6 parts.

Limnobium Spongia. Floating herb with pendent roots and many stolons; troad, clustered, purplish leaves; monoecious flowers from 2-bracted spathes, the sterile flowers on scapes with 6-12 stamens, monadelphous; fertile flowers on shorter ard thicker scapes recurving at maturity, with a $6-9$ celled ovary and some abortive stamens; fruit a berry.

\section{Poaceae (Gramineae), Grass Family.}

Stems mostly hollow, with 2-ranked leaves, the margins of their sheaths not united; fruit a caryopsis or grain. (About 45 species in Volusia.)

\section{Cyperaceae, Sedge Family.}

Stems rarely hollow, with 3 -ranked leaves, the margin of their sheaths united; fruit an achene (About 40 species.)

A tall grass on the sand-dunes along the coast is Uniola paniculata or Sea Oats; the white-tupped serige often seen along the roadside is Dichromena colorata (leucocephala). Cuitivated for ornament are Arundo donax, Bambusa argentea and other Bamber-species; also Cortaderia or Silver Pampas Grass. Eulalia with lengthwise or crosswise stripes, and Cyperus alternifolius, called L mbrella-fern but belonging io the selges. Cultivated fur use are Sugur-ione. Saccharum officinarum, and Indiun Corn. Zea Mays, the latter with the following sub-species: everta ( (rod corn), indurata (flont corn), saccharata (sweet or sugar corn). etc. The tuberkearing Cyperus esculentus is known as (inifu. As lawn-grasses are userd St. Lucie (Gyoodon dactylon), Bermuda (Capriola dactylon'. It. A uqu tine (Stenotaphrum gla- 
brum) and in winter Italian Rye grass (Lolium Italicum) or English Rye grass (Lolium perenne, Darnel.)

\section{Arecaceae, Palm Family.}

Shrubs or trees with an erect or horizontal caudex growing by a single terminal bud; leaves at the end of the stem; petioles imbricated at the base; blades plaited in the bud, fanshaped in our wild species; flowers in a decompound spadix; sepals 3 , petals 3 , stamens 6 , carpels 3 , united or distinct.

1. Petioles concave above, sharp-edged, - _ - _ _ - Sabal

S. glabra (Adansonii), Dwarf Palmello. Low shrub with subterranean stem; leaves clustered, glaucous or pale green, blades longer than the petioles; drupes black, globose. Low ground. Summer.

S. Palmetto, Cabbage Palmetto. Tree; leaves several, spreading or drooping, deep green and lustrous; blades as long as the petioles; drupes black, subglobose. Low ground and cultivated. Summer.

2. Petioles armed on the edges with rigid spine-like teeth, - _ - Serenoa

S. Serrulata, Saw Palmelto. Shrub with creeping stem; leaves ascending or erect, light green; petioles longer than the blades; drupes black, ovoid. Spreading in sandy soil. Summer.

3. Petioles 3-angled, woolly beneath, the edges denticulate, - Rhapidophyllum

R.(Chamaerops) Hystrix, Blue Palmetto, Needle Palm. Shrub with erect or creeping stem; sheaths of fibres interwoven in the stout spines; drupes red, ovoid. Shady pine-land. Early summer.

Several Palms are cultivated in tubs and in Winter indoors, or in open ground, especially species of the following genera:

In open ground:

With pinnate leaves; Cocos (Alphonsii, Bonnelti, coronata, plumosa), and Phœnix or Date-palms (Canariensis, pumila, reclinata, and sylvestris.)

With fanshaped leaves; Chamaerops (excelsa and humilis), and NeoWashingtonia sonorae, Thread-palm.

In tubs:

With pinnate leaves: Areca; Caryota (mitis and urens), Fishtail or Toddy palms; Kentia forsteriana; Seaforthia elegans; Cocos Weddelliana and Phœnix rupicola.

With fanshaped leaves: Latania, Chinese Fan Palm; Livistonia rotundifolia; Thrinax barbadensis and $T$. radiata.

\section{Araceae, Arum Family.}

Mostly acaulescent fleshy herbs with rootstocks or tubers; flowers on a thick spadix, the sterile above the fertile; spadix with a spathe; stamens $4-10$, with short filaments; carpels 1-several, united; fruit a berry or utricle.

1. Flowers monœecious or diœcious, perianth wanting, - - - - -2

1. Flowers perfect, perianth scale-like, - - - - - - - 4

2. Spadix free, with numerous fertile flowers, - - - - - - 3

2. Spadix adnate to the spathe, one fertile flower, - - _ - - Pistia 
P. Stratiotis (spathulata), Woler Lettuce. Pree floating herbs with fibrous roots and clustered entire leaves; spathe white, axillary; staminate flowers surrounded by a cup-like involucre. In dead branches of the St. Johns river.

3. Leaves palmately divided, spadix included, - _ _ _ - Arisaema

A. triphyllum, Indian turnip. Jack-in-the-pulpit. One or two leaves with 3 segments. scape shorter than the petioles; spathe white below. striped with brown or purple above; spadix stout; fruit bright red.-A more slender species with the spathe green throughout is A. acuminatum.-Low rich soil. Spring.

3. Leaves pedately divided, spadix exserted. _ _ _ _ _ Muricanda M. Dracontium, Dragon-rool. Scape shorter than the solitary leaf; sterile portion of spadix slender and prolonged far beyond the spathe; fruit bright red. Moist ground in hammocks. Spring.

3. Leaves simple, spadix covered with the flowers, - _ - Peltandra

P. Virginica, Arrow Arum. Leaves sagittate or hastate; scape as long as the petioles; spathe green enveloping the spadix, flowers inconspicuous; fruit green. - A species with white spathe and crimson fruit is $\mathbf{P}$. alba.-Marshes. Spring and early Summer.

4. Scape club-shaped with spadix at the top. - _ _ _ - Orontium

O. aquaticum, Golden Club. Bog-torch. Swamp herbs with deeply buried rootstocks; leaves thick, entire; spathe at first enclosing the spadix. later only a sheath-like bract at its base; scape white, spadix golden yellow; fruit green. Ponds. Spring.

4. Scape leaf-like with the spadix more or less lateral.

- Acorus

A. Calamus, Sweet-flog. Swamp-herbs with aromatic horizontal rootstocks; leaves linear, sheathing; scape erect apparently extending into the swordlike spathe; spadix yellowish, lateral, naked; flowers perfect, perianth 6; fruit gelatinous inside. In wet places. Spring.

To this family belong the Caladiums, Colocasias, and Alocasias, cultivated for their beautiful leaves; also the Richardias or Calla-lilies, cultivated for their white or yellow spathed flowers. The Dasheen, a substitute for the Irish potato is the corm or tuber of a Colocasia.

\section{Lemnaceae, Duckweed Family.}

Minute disk-like plants, solitary or $2-5$ in a colony, reproducing by lateral branching; two propagative pouches from which a spadix with 1 fertile and 2 sterile flowers arises; flowers consist of 1 pistil or 1 stamen; fruit a utricle. In ponds.

Lemna minor with solitary root, and L. (Spirodela) polyrrhiza with several roots.

\section{Mayacaceae, Mayaca Family.}

Moss-like herbs with creeping stems and numerous pellucid, narrow leaves; flowers solitary, perfect, on axillary pedicels; sepals 3 , narrow; petals 3 , white or purple; stamens 3 at the base of the petals; style single with 3 -lobed stigma; capsule 3-celled. 
M. Aubletii (Michauxii). Stems tufted, pedicels longer than the leaves.-A species with pedicels shorter than the leaves is $\mathbf{M}$. fluviatilis.-Ponds and around springs. Summer.

\section{Xyridaceae, Yellow-eyed Grass Family.}

Stemless herbs with equitant linear leaves and perfect flowers collected in a bracted spike; the scape, commonly twisted or spiral, with a spathe-like sheath at the base; sepals 3, the two lateral persistent, keeled and often winged, the third deciduous; petals 3 , yellow (in one species white), fugacious; stamens 3 , usually alternating with 3 bearded staminodia, hypogynous; style 1 with 3 stigmas; ovary 1-3 celled. In low pine land or swamp. XYRIs.

1. Annual or biennial; leaves shorter than the sheath of the scape, - $\quad-\quad-2$

1. Perennial; leaves longer than the sheath, - - - - - - -3

2. Keel of the lateral sepals smooth or nearly so. Spring, - - $\mathbf{X}$. brevifolia

2. Keel of the lateral sepals short-fringed. Spring, - $\quad$ - X. flabelliformis

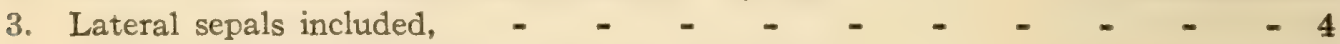

3. Lateral sepals more or less exserted, - - - - - - - - 6

4. Wing of lateral sepals ciliate, narrow. Summer and Fall. - - X. ambigua

4. Wing or keel of lateral sepals indented, - - _ - - - - 5

5. Lateral sepals keeled from below the middle or the base to the apex

Summer and Fall, - - - - _ - - X. neglecta

5. Lateral sepals keeled from about the middle to the apex; bracts very

broad and truncate at the apex. Summer and Fall. - $\mathbf{X}$. platylepis

6. Plants not bulbous at the base; leaf-bases not much dilated, - $\quad-\quad-7$

6. Plants bulbous at the base, also the leaf-bases greatly dilated, - - -8

7. Leaves numerous, narrowly linear. Summer. - - - X. Elliotti

7. Leaves few, linear; upper part of scape rough. Summer and Fall. $\mathbf{X}$. fimbriata

7. Leaves few, linear; upper part of scape smooth. Summer. - X. Smalliana

8. Corolla yellow, upper part of scape and the spike green. Spring.

X. arenicola (torta)

8. Corolla white, upper part of the scape and the spike more or less glaucous. Spring.

X. pallescens

\section{Eriocaulonaceae, Pipewort Family.}

Acaulescent marsh-herbs with the leaves clustered; scapes simple, subtended by sheathing bracts; the monœcious white flowers bracted and densely crowded in a terminal involucrate head; sepals, petals, stamens, styles and cells of ovary $2-3$, or the stamens twice as many.

1. Stamens 2-3,

1. Stamens 4-6, - - $\quad$ - $\quad$ - $\quad$ - $\quad$ Eriocaulon, Pipewort

E. compressum (gnaphalodes). Leaves shorter than the sheath at the base; scapes 2-10 dm., 10-12 ridged; heads over $10 \mathrm{~mm}$. Marshland. Spring and Summer. 
E. decangulare. Leaves innger than the sheath; scapes $3-10 \mathrm{dm} .10$-14 ridged; heads over $10 \mathrm{~mm}$. Marshland. Spring to Fall.

E. Ravenelli. Leaves longer than the sheath; scapes 1-3 dm., 5-6 ridged; heads $5 \mathrm{~mm}$. Wet grounds. Summer and Winter.

2. Peis's of pistillate fowers 3, cohering helow. - _ - - Syngonanthus

S. Paeralanthus) favidulus. Leaves linear, scapes 1-3 dm., 5-angled, very slender. putescent, heads $5 \mathrm{~mm}$. Low pine-land. Spring and Summer.

2. Fitals of fistillate Anwers none or reduced to hairs, - _ - Lachnocaulon

L. minus (Michauxii). Leaves linear, scapes pulescent $0.5-3 \mathrm{dm}$.; heads gray or brownish-gray. Moist soil. Spring and summer.

\section{Commelinaceae, Spiderwort Family.}

Herbs with erect or creeping stems, alternate leaves with sheathing bases, perfect fowers solitary or in umbellike cymes, calyx herbaceous, corolla showy, stamens 5-6 of which 2-3 may be sterile, carpels 2-3 united, ovary suferior, styles united, stigma obscurely 2-3 lobed; fruit a capsule.

1. Petals alike; stamens 6 , hairy, all normal, - - - - - - - 2

1. Petals unlike; stamens 3, smooth, and 2-3 staminodia, - - Commelina

C. Virginica, Doy- or Dew-flower. Stems spreading or decumbent; sheath more or less hairy; involucre spathe-like, folded; flowers irregular, in cymes; sepals 3. partly united; petals 3 , fugacious, two large, one smaller, Sandy pine-land. Summer and Fall.-In low swampy places is found C. erecta, with stout erect stems.

2. Cymes with very small tracts unlike the leaves, _ _ _ Cuthbertia

C. (Tradescantia) rosea, Spiderwort. Stems erect, flowers in umbel-like cymes of 3-10 at the ends of long feduncles and subtended by small bracts, sepals 3: petals 3, rose-colored, distinct. Sandy pine-land. Spring and Summer.

2. Cymes $\pi^{\prime}$ th $2-3$ bracts similar to the leaves. - - Tradescantia, Spiderwort

a. Sheaths not imtricated at the tase of the stem; plants glaucous; stem tall, often branched; leaves almost linear; bracts 2 , uneqgual, reflexed; corclla blue. Sandy or clayey soil. Spring and Summer,

a. Sheaths imbricated at the base of the stem,

b. Plan:s glandular, sheaths small, ciliate;-stem erect or assurgent; leaves linear, almost as long as the stem; bracts 2. small; corc.lla deep-triue. Sandy pine-land. Spring and Summer, - T. longifolia

b. Plants glat,rous or glabrate, sheaths large, villous;-stem erect, very leafy near the base; leaves narrowly linear, about as long as the stem; bracts 3. unequal; corolla blue. Hammocks. Spring, - - - - - - - - - T. foliosa

Cultivated members of this family are:

Tradescantia viridis (fluminensis), Wandering Jew. Stems trailing or the cols of the shrots ascending. glabrous, shining; leaves ovate, acute, sessile. chiate at the hase, sheaths leng; fewers white, hairy inside, borne in a sessie ciuster, sul,tended ty two unequal bracts; stamens 6 , equal.

Tradescantia zebrina (Zebrina pendula), Ul onderıng Jew. Stcms trailing, 
rooting at the joints; leaves lance-ovate, sessile, with under surface redpurple, upper silver-white suffused with purple; flowers rose-red, contained in two boat-shaped unequal bracts; stamens 6 , equal.

\section{Pontedariaceae, Pickerel-weed Family.}

Herbs with rootstocks and alternate or clustered leaves; flowers solitary or in spikes subtended by leaflike spathes; the 6 parts of the colored perianth partially united; fruit a utricle or a capsule.

Pontedaria cordata, Pickerel-weed or Wampee. Rootstocks horizontal; leaves ovate, often sagittate; spike with bract-like spathe; perianth blue or white, upper lobe with yellow dots; stamens 6 , unequally inserted on the perianth; style filiform; ovary superior, 3-celled. Borders of ponds and river. Spring to Fall.

Piaropus (Eichhornia) crassipes, Water-hyacinth. Rootstocks floating with rootlets at the nodes; petioles inflated, leaves roundish; perianth bluish-purple, showy, upper lobe with a yellow spot; stamens inserted on the perianth, 3 included, 3 exserted. In St. Johns river and branches. Summer and Fall.

\section{Bromeliaceae, Pine-apple Family.}

Mostly epiphytes, pendent or erect, with scurfy foliage; flowers solitary or in pairs or in spikes, subtended by bracts; sepals and petals 3 ; stamens $3-6$; ovary 3 -carpeled with 1 style and spreading stigmas; ovules numerous; fruit generally a capsule.

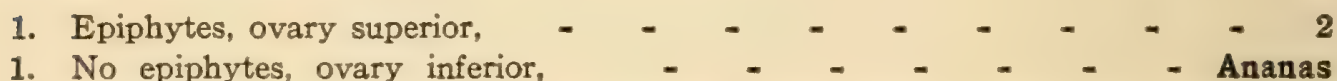

Ananas sativus, Pine-apple. Cultivated, here mostly under shed; stem erect, scape-like; leaves mainly basal, spiny; the cone-like fruit from a consolidated flower-spike.

2. Stems string-like, branching, hanging in festoons of $1-6 \mathrm{~m}$. from the branches of trees; flowers axillary, solitary, - - - - Dendropogon

D. (Tillandsia) usneoides, Spanish Moss. The fliform stems and leayes covered with silvery scales; sepals green, petals yellowish. Spring.

2. Stems not pendent, flowers mostly in spikes. Hammocks. Summer.

a. Flowers blue or violet: - _ - - - Tillandsia, Air-plant

T. recurvata (Bartramii). Flowering stems scape-like, filiform; plant fuzzy.

T. tenuffolia (Bartramii and caespitosa). Flowering stems leafy; basal leaves not shorter than the stem; scurfy; plant often reddish.

b. Flowers white, pink or purple,-T. utriculata and T. aloifolia.

The Billbergias, epiphytes, with stiff pine-apple-like leaves in a rosette, from which the spikes or spicate panicles arise, are cultivated in greenhouses.

29. Melanthaceae, Bunch-flower Family.

Caulescent or scapose herbs; flowers mostly in racemes or panicles, perianth often inconspicuous, sepals and petals 3 each; stamens mostly 6 , with the filaments adnate to 
he perianth; styles 3 , distinct; ovary superior, 3 -celled; ruit a capsule.

Stamens 6, - $---\infty-\infty-\infty-\infty-\infty$
Stamens 9-12, - - - - - - -2

P. tenuifolia. Rigid, rush-like herb with narrowly linear leaves, mainly basal; raceme 3-9 flowered, interrupted; perianth linear, spreading. Swampy pine-land. Fall.

Flowers perfect, - - - - - - - - - - - 3

Flowers moncecious or polygamous, - - - - - - - -7

Flowers dicecious, - - - - - - - - - Chamaelirium

C. Juteum, Blasing-Star, Deril's-Bit. Caulescent fleshy herbs with spatulate, broadly petioled leaves, mainly basal; racemes spike-like, staminate perianths white; sepals and petals narrowly linear. Open woods. Spring and Summer.

Plowers in spikes, - _ - - _ - - - Schoenocaulon

S. dubium (gracile). Scapose herbs with linear basal leaves; spikes slender. interrupted; perianth greenish, with oblong leathery leaves. Dry pineland. Spring.

Flowers in racemes, - - - - - - - - - - 4 Flowers in panicles, - _ - - - - _ - - - 6 Arthers oblong or ovate, - - - - - - - Xerophyllum

X. asphodeloides, Turkey-beard. Stems with numerous sessile, linear leaves; racemes many-flowered. perianth white; capsule with 2 seeds in each cell. Dry pine-land. Early Summer.

Anthers cordate or reniform, - _ - _ - _ - - - 5

Orules few in each cell; seeds 1-2 in each cavity, thick, reddishbrown, - - - - - - - - - - Chrosperma

C. (Amianthium) muscaetoxicum, Fly-poison. Caulescent herbs with numerous leaves, mainly basal, linear; racemes cylindric, continuous; perianth white, turning greenish; capsule 3-lobed. In sandy woods. Summer.

Ovules several in each cell; seeds few, narrow, - _ - Tracyanthus

T. (Zygadenus) angustifolius, Amianthium angustifolium, Crow-poison. Caulescent herbs with alternate, linear, mainly basal leaves; racemes terminal; perianth white, turning purplish. Low ground. Spring.

Sepais and petals glandless,

Triantha

T. racemosa (Tofieldia pubens). Pubescent herbs, more or less viscid; leaves linear, mainly basal; panicles narsow, interrupted; perianth whitish; seeds appendaged at each end. Low ground. Summer.

Sepals and petals with 2 glands near the base, - _ _ $\quad$ Zygadenus

Z. glaberrimus. Caulescent berbs with glaucous, linear, alternate leaves; perianth white; seeds angled. Swampy ground. Summer.

Perianth brown; sepals and petals pubescent, glandless; seeds several in each cavity, flat, broadly-winged, - - - - - Veratrum

V. intermedium, False Hellebore. Leaves narrow-elliptic with short sheathing petioles; those on the stem lanceolate to linear. Hammocks. Summer.

Perianth white, sepals and petals glandless; sceds about 4 in each cavity, angled, - - - - - - - - Stenanthium

S. gramineum (angustifolium). Caulescent, slender berbs with lineas, mainly 
basal leaves; flowers polygamous, the upper ones in each branch of the panicle fertile. Open woods. Summer and Fall.

7. Perianth greenish-yellow, turning brown; sepals and petals with two glands at the base; seeds flat, winged, _ _ _ _ Melanthium

M. Virginicum. Caulescent herbs with linear, pubscent leaves on the stem, mainly below the middle; flowers in a narrow panicle. In grassy, swampy places. Summer.

\section{Juncaceae, Rush Family.}

Grass-like herbs with a regular, 6-parted, chaffy perianth; stamens 3 or 6 ; ovary superior, style 1 , stigmas 3 ; fruit a capsule.

Glabrous herbs; leaves terete or flat; sheaths open; flower-bracts

1 or 2, usually entire, - - - - - - Juncus, $R$ ush

1. Inflorescence lateral, - - - - - - - - - - - 2

1. Inflorescence terminal, - - - - - - - - - - 4

2. Flowers not in heads on the branches of the inflorescence, _ $-\ldots$

2. Flowers in heads on the branches of the inflorescence;-scape stout, rigid; flowers usually dicecious, heads $2-8$ flowered in a compound panicle; stamens 6 or reduced to staminodia. Salt marshes.

Late Spring, - - - - - - J. Roemerianus (maritimus)

3. Stamens 3;-scape straight, not rigid; leaves basal, filiform, small; panicle decompound. Bogs. Summer and Fall, - - J. effusus

3. Stamens 6;--scape weak, slender; plants densely tufted; panicle small. Coastal marshes. Summer, - - - - - - J. setaceous

4. Flowers not in heads on the branches of the inflorescence; stamens 6 .

J. tenuis. Stems wiry; leaves flat-filiform; panicle loose. Low ground. Early Summer.

J. dichotomus. Stems wiry; leaves round-filiform, channelled; panicle forked or dense. Low ground. Early Summer.

J. bufonius. Stems slender, flower-bearing nearly the whole length, flowers remote. Roadsides. Spring and early Summer.

4. Flowers in heads on the branches of the inflorescence; stamens 3 .

J. scirpoides. Stems rigid; leaves terete, with complete septa; heads 2-30 flowered, style usually exserted. Hammocks and sandy swamps. Summer.

J. polycephalus. Stems stout; leaves flattened with incomplete septa; heads 20100 flowered, distant. Banks of streams. Summer.

J. Elliottii. Stems, leaves, and panicles erect; heads 3-8 flowered. Bogs and ditches. Summer and Fall.

\section{Alliaceae, Onion Family.}

Acaulescent herbs with bulbs; leaves basal, narrow; scapes simple; flowers perfect in terminal umbels, subtended by 1-3 membranous bracts; perianth 6-parted; stamens 6 , adnate to the perianth; ovary superior, 3 -celled; style jointed.

1. Wild plants,

1. Cultivated,

2. Ovules 2 in each cavity; plants odorous, 
A. Canadense, Meadow Gurlic. Umbels consist of bulblets and some pinkish flowers; pedicels few and slender; Alaments about as long as the perianth. Riverbanks. Spring.

A. mutabile, Wild Onion. Flowers white to rose; pedice's numerous, slender; filaments shorter than the perianth. Dry goil. Spring.

2. Orules several in each cavity; plants inodorous. - - - Nathoscordium

N. bivalve (Allium striatum), Fulse Garlic. Flowers white; filannzis shorter than the perianth. Sandy soil. Spring.

3. Scape stout, inflated near the base, much exceding the hollow leaves;

flowers in round umbels, whitish. Many varieties. Allium Cepa. Onion

3. Bulbs small, breaking up into many small bulbs (cloves); leaves very

narrow, keeled; flowers purplish, usually replaced by bulblets.

Allium sativum, Garlic

\section{Liliaceae, Lily Family.}

Caulescent herbs with bulbs or corms; flowers solit ary or in terminal racemes or panicles; sepals and petals similar, 3 each; stamens 6 ; ovary superior, 3 -celled; style 1 ; fruit a capsule.

1. Anthers versatile, ovules numerous in each cell, - _ _ _ Lilium

L. Catesbaei, Red Lily. Leaves alternate, linear, fleshy, flowers solitary and erect, scarlet with yellow and purple spots. Low pine-land. Summer.

2. Anthers introrse, ovules 2 in each cavity, - - - Oxytria (Schrealirion)

O. crocea (S. croceum). Leaves basal, narrow; flowers in racemss, bright yellow. Sandy soil. Spring.

O. albiflora (S. Elliottii). Leaves basal, narrow; flowers in panicles, white. Low pine-land. Spring.

Cultivated flowers belonging to this family, besides some species of Lily, are:

a. Tulips. Tulipa Gesneriana, in many varieties of red. yellow and white.

b. Spuills, Scilla Perusiana (Quamasia or Camassia), flowers vio.et-blue or white.

c. Hyacinshs, Hyacinthus orientalis, with racemes of purple, red, whita, ete.. flowers.

d. Chequered Lilies. Fritillaria imperialis and F. meleagris, the former witi a raceme of large drooping red flowers beneath a crown of bracts, the lattar with large nodding flowers chequered with purple and yellow.

33. Convallariaceae, Lily of the Valley Family.

Perennial herbs with rootstalks; leaves alternate, basal, or reduced to scales; flowers in racemes or panicles, or solitary; sepals and petals $2-3$; stamens 4 or 6 ; ovary superior, 2 or 3 celled, styles united, stigma lobed; fruit a berry or capsule.

1. Leaves reduced to scales. Cultivated, - - - - - Asparagus

A. officinalis. Sicm at first strut, eilitle, with brjal siales; branches filfiorm in the axils of minute scales; flowers greenish.

A. Sprengeri. Sim an 1 branches siender, dropping; fl wers whitish in razmes; berries red. (Asparagus F ern) 
A. plumosis. Stem and branches flattish, spreading or climbing; flowers white, solitary; berries black.

A. medeoloides (Myrsiphyllum asparagoides), Smilax. A climber; stem slender, cladophyls thick with conspicuous veins; flowers solitary, fragrant; berries dark green.

1. Leaves normal, alternate or all basal, long, narrow, erect, with lighter transverse markings; flowers in slender panicles; perianth white, recurved fruit a capsule, - - - - - - - Sanseviera, Bowstring Hemp

S. guineensis with flat leaves; S. zeylanica, with concave leaves.

\section{Dracaenaceae, Yucca Family.}

Plants with woody caudex; leaves many, alternate, firm or rigid, narrow; flowers mainly white, in panicles, on scapes; sepals and petals nearly alike, 3 each; stamens 6 ; ovary superior, mostly 3 -celled; styles united; stigmas 3 , nearly sessile; fruit a capsule.

1. Sepals and petals distinct or nearly so, - - _ - - - Yucca

Y. filamentosa, Bear Grass. Caudex short; leaves firm with coarse and curly fibres on the margins; scapes $2-4 \mathrm{~m}$. tall. In sandy soil. Early Summer.

Y. gloriosa, Spanish Daggers. Caudex tall, simple; leaves numerous, narrow, rigidly pointed; panicle showy, short-peduncled. In sand or cultivated. Early Summer.

Y. aloifolia, Spanish Bayonet. Caudex tall, branching; leaves numerous, broader than in the preceding species, spreading above and deflexed below; panicle showy, nearly sessile. Cultivated here, wild or escaped in the sand-dunes along the coast. Early summer.

1. Sepals and petals united below,

Dracaena

A genus of ornamental plants, frequently with variegated leaves, is Dracaena (Cordyline); the leaves are sword-like or broad; the flowers clustered in panicles or heads; the perianth is greenish, white or yellow, salverform or campanulate, with spreading lobes; best known are $\mathbf{D}$. draco or Dragon-tree, and $\mathbf{D}$. fragrans, with green foliage, D. Lindeni with leaves creamy-striped on the sides, C. australis tall and fairly hardy, C. Haageana dwarf, and C. terminalis with bronzed green leaves marked with pink or carmine.

\section{Smilacaceae, Smilax Family.}

Vines with alternate leaves and diœcious flowers in axillary umbels; sepals and petals 3 each, mostly green; stamens 6 ; ovary 3 -celled, sessile stigmas 3 , ovules $1-2$ in each cell; fruit a berry.

1. Stems herbaceous, unarmed; ovules 2 in each cell; leaves ovate or lanceolate, 3-5 veined, cordate at the base; flowers fetid; berries red. Dry soil. Summer.

Smilax (Nemexia) herbacea, Coprosmanthus herbaceus, Carrion-flower

1. Stems woody, mostly prickly; ovule solitary in each cell, - - Smilax

a. Glabrous, climbing,

a. Pubescent, prostrate, trailing, often unarmed; leaves 3-5 veined, cordate at the base; berries red. Dry pine-land. Fall. - S. pumila 
b. Leaves abrugt or roundish or cordate at the base, 5-9 veined. - - c

b. Leaves acute at the base, $3-5$ veined, and peduncles not longer than the petioles,

c. Berries black,

c. Berries red; leaves 5-veined; stem high-climbing. Margin of swamps. Summer. - - - - - - - S. lanceolata

d. Leaves often more or less strongly auricled, or dilated, strongly 3-ribbed; stems low-climbing; flowers fragrant. Dry sand or pine-land. Summer. - - _ - - S. Beyrichii (auriculata)

d. Leaves elliptic, 3-veined; stems high-climbing, prickly; berries white during the first year, later black. Moist thickets. Summer. - - _ - _ - - _ - - S. laurifolia

e. Leaves ovate or oblong or round-ovate, - $\quad$ - $\quad$ - $~ f$

e. Leaves fiddle-shaped or hastate; peduncles long; stems highclimbing, prickly; berries black. Moist thickets. Early Summer. - - - - - S. Bona-nox (tamnoides), Stretch-berry

f. Plants prickly, - _ - - - - - - - - g

f. Plants unarmed, except few prickles on the lower stem; peduncles $3-4$ times as long as the petioles; leaves $7-9$ or 11 veined. often contracted in the midale; berries black. Dry soil. Spring.

S. Pseudo-China, Bamboo-vine, or China-brier

g. Leaves green, peduncles not longer than the petioles, - _ - - $\mathbf{h}$

g. Leaves glaucous beneath. 5-7 veined; peduncles 2-3 times as long as the petioles; berries bluish black, glaucous. Sandy soil. Spring. - _ _ _ _ - _ - - S. glauca

h. Berries blush black; stems climbing high. Swampy thickets. Early Summer. - - . - - - - - S. rotundifolia

b. Berries coral-red; stem low with few prickles near the base. Swamps. Spring.

S. Walter $\mathrm{i}$

36. Leucojaceae (Amaryllidaceae), Amaryllis Fumily.

Herbs with basal, usually sheathing leaves; perfect flowers with an epigynous perianth of 6 ; stamens 6 inserted on a disk or on the throat of the perianth, filaments sometimes united at the base or connected by a crown; inferior or half inferior ovary, $1-3$ celled; 1 style with an entire or 3-lobed stigma.

1. Stamens connected by a membrane forming a crown upon the perianth; scape terminated by a single flower or by a bracted umbel.

Hymenocallis (Pancratium), Spider Lily

H. rotatum. Leaves linear; flowers $2-6$ on the scape, white with short, greenish tube. Low sandy places. Early summer.

1. Stamens not connected that way, - - _ - - - - - 2

2. Parts of the perianth united into a tube, growing from bulbs. - - 3

2. Parts of the perianth distunct down to the ovary, growing from rootstocks, 4

3. Tube long and slender, abruptly spreading; stamens exserted, anth. ers versatile; style elongated,

Crinum, Butberfly Lily

C. Americanum. Succulent scape topped by a $2-4$ flowered umbel, with a broad. 
2-valved spathe; perianth white with green tube. River-swamps. Summer.-Several species of Crinum are cultivated.

3. Tube short or long, gradually expanding; scape fleshy, 1-flowered; stamens adnate to the throat of the tube, anthers versatile; style filiform, - - - - - - - Atamasco (Zephyranthes)

A. Atamasco, Atamasco-lily, Easter-lily, Amaryllis Perianth white or light purple; stamens included. Low ground. Spring.-Some species with red or red-striped flowers are cultivated.

4. Ovary half-inferior; stems scape-like, leaves mainly basal; flowers in an elongated, interrupted, terminal raceme; stamens included.

Sandy pine-woods. Early Summer. - - - Aletris, Colic-root

A. aurea, with a yellow, campanulate perianth,

A. obovata, with a white, obovoid perianth.

4. Ovary wholly inferior; acaulescent, leaves grass-like; scapes solitary

or tufted; flowers solitary or umbelled; stamens short; perianth

yellow within,

H. juncea with sheathing filiform leaves. Pine-land. Spring.

H. erecta with hirsute linear leaves. Sandy soil. Spring to Fall.

Among the cultivated plants of this family are:

Galanthus nivalis or Snowdrop (flowers white), Leucoium vernum or Snowflake (sepals white, tipped with green or yellow),-both with a regular perianth like Hypoxis. Further: Eucharis grandiflora, Amazon Lily,and many species of Narcissus cultivated as Daffodils and Jonquils with a firm cup crowning the perianth. Finally the Agave or Centuryplant, also called American Aloe, and Polyanthes tuberosa, Tuberose.

\section{Tamaceae, Yam Family.}

Twining vines from rootstocks; simple and petioled leaves, opposite or whorled near the base of the stem and alternate above; flowers monœcious or diœcious in axilliary inflorescence; perianth 6 , partially united, green or whitish; stamens 3-6; ovary 3-celled, inferior; styles 3 with entire stigmas; fruit a capsule.

Dioscorea villosa, Wild Yam. Stem herbaceous; leaves cordate, 7-11 veined, on slender petioles; flowers whitish; the sterile in panicles, the fertile in racemes or spikes. Low ground. Summer.

\section{Ixiaceae (Iridaceae), Iris Family.}

Caulescent herbs from rootstalks; leaves equitant and 2-ranked; perfect flowers solitary or in clusters, with a 2-leaved spathe; perianth 6-parted, colored; stamens 3 , adnate to the perianth; inferior ovary, 3-celled; fruit a capsule.

1. Styles filif orm or united.

1. Styles petal-like, arching over the stamens;-rootstock creeping or tuberous; our species with leafy tall stems and sword-shaped blades; flowers solitary or spiked, showy. Swamps. Spring and Summer.

Iris, Blue Flag, Fleur-de-lis 
1. tripetala. Flowers terminal, usually solitary, blue with yellow and purple; lobes crestless, tube shorter than the ovary.

1. versicolor. Plowers terminal, single or spiked, blue or lilac with white, yellow or purple; lobes crestless, tube shorter than the ovary.

1. heragona. Plowers axillary and terminal, solitary, nearly sessile; violet-blue with white, yellow and purple; lobes crested, tube longer than the ovary.

2. Styles each parted into two filiform segments;-rootstock coated bulb-like; narrow, folded, alternate leaves; flowers 1-3 with two fugacious bracts, showy. Pine-woods. Spring and Summer, - - Nemastylia

N. (Iria) coelestina. Leaves diminishing upward till bract-like; flowers solitary. bright blue; the lobes of the perianth broadest above the middle.

2. Styles filiform or mostly united;-stamens united; grass-like herbs with linear leaves; scapes 2-edged or 2-winged, terminated by clusters of blue, white or yellow flowers, - Sisyrinchium, Blue-eyed Grass

S. Bermudiana. Mostly in dry soil. Spring and Summer.

Cultivated species in this family are: Crocus, raised from corms, blooming mainly in early Spring; Freesia, blooming in Fall and Winter; Gladiolus, blooming in Summer; the Irias of early Spring are noted for their wide range of color.

\section{Haemodoraceae, Blooduort Family.}

Herbs with rootstocks; leaves elongated, chiefly basal; flowers perfect in terminal spikes, panicles or cymes; sepals, petals and stamens each 3 ; ovary inferior, 3 or 1 -celled, style 1 ; fruit a 3-valved capsule, generally with few seeds.

Gyrotheca (Lachnanthes) tinctoria. Rootstock red; stem corymbosely branched above; leaves basal; flowers yellowish, woolly outside. Swampy pineland. Spring to Fall.

\section{Musaceae Banana Family.}

Tall scapose herbs, commonly perennial by rootstocks or tubers; the very large leaves alternate, with sheathing petioles and the veins parallel, diverging from the midvein; flowers irregular, in clusters, each cluster subtended by a large colored bract; perianth 6-parted, 5 of the segments united and 1 distinct; stamens $3-6$, some of them abortive; ovary inferior, 3-celled, styles united; fruit indehiscent, pulpy or dry. Cultivated in many species and varieties.

Musa Sapientum, Banona. Tall scape, partly sheathed by the leaf-stalks. the pink or purple flowers in a nodding spike; perianth of 2 unequal leaves, the lower 5-toothed; filaments 6 , anthers 5 , each 2 -celled; fruits in a buge cluster, seeds abortive. Cultivated for ornament.

\section{Alpiniaceae, Ginger Family.}

Caulescent herbs with horizontal rootstocks; flowers in panicles sometimes spike-like; calyx 3-lobed; petals 
3 unequal; stamens and style included; fruit capsular. Cultivated for the flowers.

Alpinia nutans, Wild ginger-plant. Leaves lily-like; flowers with several colors.

\section{Marantaceae, Arrow-root Family.}

Scapose or caulescent herbs; flowers in panicles or single. Cultivated for the foliage.

Maranta arundinacea (Phrynium variegatum). With canna-like leaves variegated with white. Other dwarf-forms and species of Calathea are potplants.

Thalia divaricata. Large banana-like leaves with red midribs. In moist garden soil together with Canna's.

\section{Canna ceae, Canna Family.}

Herbs with erect stems and alternate, thick leaves on sheathing petioles; flowers in terminal spikes, usually with a showy perianth; sepals 3 ; petals 3 united below; stamens petal-like, only one with a marginal anther; ovary inferior, with petal-like style and marginal stigma; fruit a 3celled capsule.

Canna flaccida. Stem mostly simple, leaves oblong-elliptic; spikes with few yellow flowers. Miry swamps. Summer.

\section{Burmanniaceae, Burmannia Family.}

Small herbs with slender stems, scale-like leaves, and regular, perfect flowers; perianth 6-cleft, colored; stamens inserted on the tube of the perianth; ovary inferor, style 1 , stigmas 3 or 1 ; fruit a capsule.

1. Leaves grass-like or wanting, making the stem look scape-like; ovary

3-celled; stigma 3-lobed or capitate, Flatwoods. Summer and

Fall. - - - - - - - - o - Burmannia

B. biflora, with simple or forked stem, 1-2 flowers at the end of a branch; perianth blue, the outer lobes ovate and erect, the inner linear and incurved.

B. capitata, with simple stem and flowers in a terminal cluster; perianth white or pale blue, the outer lobes deltoid, the inner linear and involute.

1. Leaves reduced to scales on scape-like stems; ovary 1-celled; stigmas

3, capitate. Swampy woods, - - - - - - Apteria

A. aphylla (setacea), with simple or sparingly branched purplish stem and flowers in a nodding raceme; perianth purple or pale; lobes acute, the outer longer than the inner.

\section{Orchidaceae, Orchid Family.}

Herbs from tuberous or fibrous roots, corms or rootstocks; leaves mostly sheathing at the base, sometimes reduced to scales; irregular, perfect flowers, solitary or 
in an inflorescence; perianth 6 -parted, the 3 sepals and 2 of the petals similar in form, but the third petal (LIP), different. Stamens 1 or more, united with the style into a Colums; anthers 1 or 2 , containing 2,4 or 8 waxy or powdery POLLINIA; ovary inferior, 1-celled. more or less twisted; style 1, stigma a viscid surface; fruit a 3 -valved capsule; seeds minute, numerous.

1. Anther one, adnate to the column, erect, persistent, - - - - - 2

1. Anther one, attached to the apex of the column like a lid, deciduous, - - 4

2. Lip spurred, - - - - - - - - - - - - 3

2. Lip spurless, with two callosities at the base;-flowers in terminal more or less spiral spikes, small, white or yellowish. In damp

soil. - - Gyrostachis (Spiranthes), Twisted Qrchis or Ladies' Tresses,

G. gracilis. Stem slender, scape-like; spike one-sided or spiral. Summer.

G. praecox (S. tortilis). Stem tall and slender, spike spiral. Summer.

G. odorata. Stem stout, leafy; spike thick, spiral. River-banks. Fall.

G. cernua. Stem scape-like, scaly; spike blunt not spiral. Fall.

G. brevifolia. Stem scape-like, scaly; flowers in one row. Fall.

2. Lip spurless narrowed into a claw; petals and lip adnate to the middle of the column; pollen-masses 4, powdery; flowers in a glandular pubescent terminal raceme or spike, greenish. Flatwoods, - - Ponthieva

P. glandulosa. Stem scape-like; leaves broad, radical. Fall.

3. Lip fringed or cut-toothed;-flowers in terminal spikes, bracts sometimes leaf-like. In swamps.

Blephariglottis (Platanthera), Fringed Orchis

B. cristata. Stem stout, leaves linear, spike oblong; flowers small, yellow, with slender spur. Summer.

B. ciliaris. Stem stout, leaves oblong, spike oval; flowers large, orange, with slender spur. Summer.

B. Blephariglottis. Stem stout, leaves oblong, spike oval; flowers white, with slender spur. Summer.

3. Lip 3-parted, anther with slender appendages;-flowers in terminal spikes, stems leafy. In the flatwoods. - - Habenaria, Rein-orchid

H. distans. Stem scape-like with oblong leaves at the base; spike few-flow. ered, flowers white, spur club-shaped. Summer.

H. repens. Leaves many, lanceolate, sheathing; spike many-flowered, flowers greenish, spur filiform. Late Summer.

H. quinqueseta (Michauxii). Leaves oblong, spike few-flowered, flowers white, spur long, slender. Summer.

3. Lip entire or 3-toothed, anther without appendages;--stem with alternate leaves. In pine-barren swamps.

Gymnadeniopsis (Gymnadenia)

G. nivea. Stem slender with linear leaves on the luwer part; spike cyininiric, flowers white or pink; ovary not twisted; spur filiform, not shurter than the ovary. Summer.

G. integra (flava). Stem slender with broadly linear leaves below; spike oblong. flowers orange-yellow; ovary twisted; spur filiform. shorter than the ovary. Summer.

4. Pollen in powdery masses. 
4. Pollen in waxy masses, - - - - - - - - - 6

5. Scapose herbs from corms, flowers in a terminal spike or raceme;scape erect, bearing below the middle a single narrow leaf; lip hinged, bearded on the surface. Low pine-land.

Limodorum (Calopogon), Grass Pink

I. pallidum (C. pallidus). Spike interrupted, 10-20 flowered; flowers white tinged with purple; filaments on lip purplish. Early Summer.

L. tuberosum (C. pulchellus). Spike not dense, 3-20 flowered; flowers purple; filaments on lip pink, yellow or orange. Summer.

I. graminifolium (C. parviflorus). Spike 3-7 flowered, flowers bright purple; filaments on lip yellow. Spring.

5. Caulescent herbs from slender roots, flowers $1-2$ at the top of the stem;-stem erect, few-leaved; leaves basal and 1 or 2 on the stem; flowers nodding. In swamps. - - - _ - Pogonia

P. ophioglossoides. Perianth rose-colored, sepals and lateral petals of equal length; lip spatulate, bearded and crested. Spring.

P. divaricata. The purplish brown sepals longer than the pink-colored lateral petals; lip 5-lobed, merely crested, greenish veined with purple. Early Summer.

6. Caulescent herbs with short corms;-low herbs with 1-2 leaves on the stem; small flowers in a terminal raceme, white or greenish; sepals spreading; lateral petals very narrow; lip broad, cordate or sagittate at the base; pollinia 4, united by pairs. Riverhammock. - - - Achroanthes (Microstylis), Adder's Mouth

A. unifolia (M. ophioglossoides). Flowers in a short raceme, pedicels slender, lip 3-toothed at the apex; a leaf near the middle of the stem. Summer.

A. Floridana. With 2 basal leaves; raceme slender; lip entire at the apex.

6. Saprophytic herbs with coral-like branching roots;-scaly, sheathing leaves; dull colored flowers in a terminal raceme; sepals and petals nearly alike, connivent; lip clasping the 2-edged column; pollinia 4, a pair in each sac, Pine-land, - - Corallorhiza, Coral-root

C. Wisteriana. Plant light or deep purple or brownish; lip broadly oval or obovate, clawed, and notched at the apex; column strongly winged. Winter or Spring.

C. odontorhiza. Plant light or deep purple; lip obovate or suborbicular, clawless, and not notched at the apex; column narrowly winged. Summer.

C. micrantha. Plant pale or greenish purple; lip oblong or oval. Summer and Fall.

6. Epiphytes clinging to the bark of trees;-flowering stems simple or branched, each terminated by a raceme or panicle; sepals and petals nearly equal, spreading; lip 3-lobed; spur none. All but one species in South-Florida; on trees in hammocks.

Epidendrum, Tree-Orchis

E. conopseum. Plants tufted, roots matted, leaves leathery and sheathing at the base; perianth green tinged with purple. Summer.

\section{Spermatophyta. Dicotyledones.}

46. Saururaceae, Lizard's-Tail Family.

Caulescent herbs with alternate or sometimesbasal leaves; flowers perfect, but instead of a perianth small 
bracts; inflorescence a terminal spike or raceme; stamens $3-8$, hypogynous, anthers introrse; ovaries $3-4$, distinct or more or less united; stigmas introrse; fruit dry or berrylike.

Saururus cernuus. Marsh herbs with jointed stems, erect from a swollen base. simple or branched; leaves winged-petioled, ovate-lanceolate to cordate or bastate, acuminate, dark green; flowers small, white, in a terminal raceme with drooping apex. Summer or Spring.

\section{Piperaceee, Pepper Family.}

Chiefly herbs with leathery, fleshy or thin leaves; flowers in solitary or clustered spikes subtended by bractlets; perianth absent; stamens 2-6, hypogynous, with distinct filaments; ovary 1 -celled with the 3 stigmas in a brushlike tuft; fruit a small drupe with a solitary seed.

Leaves petioled, flowers perfect, minute, stamens 2, - - - Peperomia

P. leptostachya. Stems erect, slender; leaves opposite or whorled, thin, finely pubescent; spikes very slender and loosely flowered. In damp woods along the river.

P. magnoliaefolia. Stems stout; leaves alternate, leathery; spikes slender, densely flowered. Hammocks.

Black and while pepper comes from Piper nigrum, with alternate leaves; dicecious, minute flowers in drooping axillary spikes; stamens 1-4.

\section{Juglandaceae, Walnut Family.}

Monœcious trees with alternate leaves, odd-pinnate, rarely entire. Sterile flowers in lateral aments with an irregular 2-6 lobed calyx, or only a single bract, or none; stamens in rows on the calyx. Fertile flowers solitary or clustered, terminal, with a calyx or 1 -several parts inserted on the ovary. Fruit drupe-like, the hard or fibrous husk enclosing a crustaceous or bony nut; seed 4-lobed. Flowers in Spring, mature fruit in Fall.

1. Bark furrowed, leaves membranous; staminate aments stout, simple, short-stalked; husk indehiscent, nut with ridges, _ _ _ Juglans

J. nigra, Black Walnut. Bark dark-brown, heartwood dark-brown; leaflets 15-23, the terminal one often suppressed, ovate or ovate-lanceolate; fruit subglobose, glabrous; nut 2 -celled above and 4-celled below the middle. In rich soil and cultivated.

1. Bark close or scaly, leaves leathery; staminate aments slender, branched. mostly long-stalked, almost sessile in Pecan; husik dehiscent, nut $s$ mooth, - - - - - - - - Hicoria (Carya)

a. Lateral leaflets falcate; seed sweet;-loliage pubscent when young, glabrous with age; bark somewhat rough; leaflets $9-15$, oblonglanceolate, acuminate; fruit oblong, with thin 4-valved husk; nut terete, amootb and even. Cultivated. 
a. Lateral leaflets not falcate; seed bitter and astringent;-bark smoothish, close with flat ridges; foliage glabrous; leaflets $3-7-9$, oblong. acuminate; fruit subglobose to pyriform with tardily separating husk; nut angled, often brown. Dunes. - Hicoria (Carya) glabra, Pignut

\section{Myricaceae, Bayberry Family.}

Mostly diøcious, aromatic shrubs with alternate, resinous-dotted leaves; flowers without perianth disposed in axillary aments; the sterile ones consisting of 2-8 stamens on a bract, the fertile ones consisting of a 1-celled ovary with 2 filiform stigmas, and at its base surrounded with a row of scales; fruit a dry 1-seeded drupe.

Leaves entire or toothed; scales of the ovary $2-4$, minute.

Morella (Myrica)

M. cerifera, Wax-myrtle. An evergreen shrub; leaves leathery, oblanceolate, entire, but often toothed toward the apex, tapering into slender petioles; staminate aments numerous, with wedge-shaped bracts; pistillate aments shorter, with broadly-ovate bracts; fruit white. Wet sandy soil; flowers in Spring, fruit in Fall.

M. inodora. An evergreen shrub with whitish bark; leaves leathery, oblongobovate, entire, with short, partially winged petioles; staminate aments stout, pistillate slender; fruit black, often solitary. Margins of pinebarren ponds. Early Spring.

\section{Salicaceae, Willow Family.}

Diøcious trees or shrubs with alternate simple leaves, and flowers in bracted aments; instead of the perianth a gland or a disk; stamens 2-many; ovary 1-celled, style short and more or less divided, stigmas 2-lobed; fruit a capsule.

1. Trees with furrowed bark, the stout twigs terminated by scaly winterbuds; leaves palmately veined, coarsely toothed or lobed, the petioles subtended by membranous caducous stipules; flowers appearing before the leaves; stamens more than 10 with red or purple anthers; style short with dilated stigmas, - - - Populus

P. deltoides, Cotton-wood, Poplar, Aspen, Large tree with deeply ridged grayish trunk, spreading angular branches, stout olive-green twigs, and glabrous foliage; leaves broadly ovate to deltoid, the flattened petioles nearly as long as the blades; stamens more than 60; bracts of aments scarious. Riverbanks. Early Spring.

1. Trees or shrubs with more or less flaky bark, the slender flexible twigs carrying winterbuds with a single scale each; leaves pinnately veined, finely toothed; petioles short with leafy or scaly stipules; flowers appearing with or before the leaves; stamens less than 10 , mostly 2, with yellow or reflish anthars; style usually short, stigmas filiform,

S. amphibia. Small tree or shrub with purplish twigs; leaves linear-lanceolate 
to oblong. glaucous beneath; bracts of the staminate aments finely pubescent; capsules about 3 times as long as the pedicels. Wet ground.

S. Babylonica (pendula), Weeping-willow, and other species of Salix are planted for ornament.

\section{Corylaceae, Hazel-nut Family.}

Monocious shrubs and trees with alternate simple leaves; staminate aments drooping; pistillate aments short, erect or ascending; fruit consisting of accrescent bracts with 1-3 nuts.

Small tree or shrub with a pale smooth bark and flowers before the leaves; staminate aments solitary, stamen; 3 -2) on a brja 1 scale; pistillate aments terminal, pistils 2 at the base of a scale; nut ovoid, seed solitary,

Carpinus

C. Caroliniana, Hornbeam, Blue Beech. Bark blue-gray; leaf oblong, smooth. Hammocks. Spring.

\section{Fagaceae, Beech Family.}

Monocious shrubs or trees; alternate leaves simple, entire, toothed or lobed; sterile flowers in aments, perianth of 4-7 partially united parts, stamens 4-20 with distinct filaments; fertile flowers solitary or several in aments, perianth of 4-8 partially united parts; ovary 3-7 celled, adnate to the perianth; styles and stigmas as many as there are cells in the ovary; fruit a 1-seeded nut in a scaly or spiny involucre.

Besides the Beech, Fagus, this family has the following genera:

1. Staminate aments erect, stamens $10-20$, styles 6 , nuts $1-3$ included in a spiny involucre or burr. - - _ - _ - - - Castanea

C. pumila, Chinquapin. Shrub or tree with smooth bark; the petioled leaves oblong or obovate, sinuate-toothed, glabrous above and white-tomentose beneath; nuts 1, rarely 2 , in a burr. Dry sandy soil. Late Spring.

1. Staminate aments drooping. stamens $6-12$, styles 3 , nut seated in an involucre of imbricated scales, or cup; nut and cup called acorn.

Quercus, Oak

a. Leaves or their lobes bristle-tipped; fruit often pubescent insi-le, - - b

a. Leaves or their lobes without bristles (except on shoots), fruit often glabrous inside,

b. Leaves deciduous, sometimes almost persistent, _ _ _ _ _ c

b. Leaves evergreen;-shrub or small tree with smonth bark; the leathery leaves small. obovate or oval, entire, or sinuate-toothed on the shorts; acorns sessile or nearly so; nut dark brown, often striate. On sandy ridges along the coast.

Q. myrtifolia (arenaria), Myrbe Oak

c. Leaves little or not at all dilated at the apex, not lobed except on shrots, sometimes with one or a few teeth near the apex. - -

c. Leaves dilated upward, 3-libed near the apex, - _ _ _ _ o

c. Leaves pinnatifid or pinnately lubed, green and glabruus on both 
sides,

d. A small tree with thick, furrowed, blue-gray bark; leaves broad, usually deeply pinnately lobed, and narrowed into a short petiole; acorns short-peduncled, cup saucer-shaped or more or less turbinate. On sandy ridges, - - Q. Catesbaei, Turkey Oak

d. A tall tree with an irregularly ridged bark; leaves oblong to obovate, 5-7 lobed, usually toothed, and lobes and teeth bristle-tipped; acorns sessile or short-peduncled, cup turbinate, cultivated.

Q. coccinea, Scarlet Oak

e. Cup of acorn shallowly saucer-shaped; leaves glabrous, thick;a tree with fairly smooth bark; leaves oblanceolate or spatulate, entire or 3-lobed at the apex, those of the shoots often pinnatifid, glabrous on both sides or slightly tomentose beneath, almost evergreen, the principal veins ending in bristles; acorns sessile or short-peduncled, nut subglobose, pubescent. In not too dry, sandy soil. - Q. nigra, L. (Q. aquatica, Walt.)

Water-Oak

e. Cup of acorn hemispherical; leaves brown-tomentose beneath;a tree with rough, black bark; leaf-blades obovate, 3-5 lobed at the apex or with one much-dilated endlobe; acorns sessile or short-peduncled, nut subglobose or ovoid. Dry gravelly or sandy soil. - - Q. Marylandica (Q. nigra, Wang), Black Jack

f. Leaves glabrous on both sides, - - - - - - _ - g

f. Leaves gray-tomentose beneath;-a tree with gray and scaly bark; leaves oblong to oblanceolate; acorns nearly sessile, cup saucer-shaped, nut oblong or subglobose. Dry pine-barrens.

Q. brevifolia (cinerea), Blue Jack

g. Tree almost evergreen, with nearly smooth bark; leaves linearoblong to narrowly elliptic, acute and bristle-tipped at the apex. usually entire except on young shoots; acorns sessile or nearly so, cup saucer-shaped, nut subglobose. In moist sandy soil; planted as a street-tree together with $Q$. aquatica under the name of "Water Oak." - - - - - - Q. Phellos, Willow Oak

g. Tree with an almost black bark; leaves oblong, entire, or lobed on shoots, or pinnatifid, bristle-tipped; acorns nearly sessile, cup saucer-shaped with a constricted base, nut ovoid or subglobose. Moist sandy soil near the coast. - - - Q. laurifolia, La urel-Oak

h. Leaves deciduous; - shrub or small tree with obovate thickish leaves, undulate or shallowly 3-lobed near the apex, lustrous above and sparingly pubescent beneath, nearly sessile; acorns sessile or nearly so, cup hemispherical, nut about twice as long as the cup. In sandy barrens.

Q. Chapmanii (Q. obtusifolia var. parvifolia)

h. Evergreens,

i. Shrub with gray bark; leaves oblong, strongly revolute, rugosereticulated, glabrous above and finely pubescent beneath; cup turbinate, tomentose, fringed at the edge; nut twice longer than the cup. Sandy soil. - - - - Q. geminata, Shrub

Live Oak

i. Stout tree with grayish, furrowed bark; leaves obovate, oblong or oval, entire except on the shoots, somewhat revolute, glab- 
rous on both sides or sometimes sparingly pubescent beneath, never rugose; acoms solitary or spicate at the end of long peduncles; cup hemispheric, nut twice longer than the cup. Sandy soil near the coast, and planted. - Q. Virgininan (Q. virens), Live Oak

\section{Urticaceae, Nettle Family.}

Herbs with simple stipulate leaves; small greenish flowers in axillary cymes, monœcious, diœecious or polygamous; sepals and stamens 2-5; ovary superior, 1-celled with 1 stigma; fruit an achene.

1. Plants with stinging hairs;-leaves opposite; flowers axillary; sepals and stamens 4

ठ. urens. Stem stout, simple or branched. Waste places. Spring to Fall.

1. Plants without stinging hairs,

2. Flowers in dense clusters, without an involucre, on slender branches; sepals and stamens $3-5$,

B. cylindrica. Leaves thin, ovate to lanceolate, acuminate, coarsely serrate, bright green. Low ground. Summer and Fall.

2. Flowers in clustered cymes; involucres of $2-6$ bracts; sepals and stamens $3-4$,

Parietaria, Pellitory

P. Floridana (debilis). Slender annual, branched, with numerous, thin, ovate leaves, 3-veined, alternate; bracts of involucre linear. Damp shaded sandy soil. Summer.

54. Cannabinaceae, Hemp Family.

Pubescent herbs, mainly with opposite stipulate leaves; flowers dicecious; staminate flowers in panicled racemes, pistillate flowers in bracted spikes; sepals and stamens 5; ovary 1 -celled, styles and stigmas 2 ; fruit an achene.

Stem twining; leaves 3-7 lobed or serrate; bracts imbricated, forming a

membranous cone in the fruit, - - - - - Humulus

H. Lupulis, Hop. Prostrate or climbing vine; leaves petioled. Cultivated or escaped. Summer.

\section{Artocarpaceae (Moraceae), Mulberry Family.}

Trees or shrubs with milky juice, alternate leaves, and deciduous stipules; flowers monœcious or diøecious in spikes or heads, or on the inside of a closed receptacle; perianth of the staminate flowers 3-4 lobed, with 3-4 stamens inserted at its base; perianth of the pistillate flowers 3-5 lobed, finally enveloping the achene; ovary 1-2 celled, styles and stigmas 1-2; fruit a syncarp or syconium.-Members of this family are planted for ornament or fruit; they bloom in late Spring or Summer.

Morus alba, While Mulbery, a small tree with the staminate and pistillate bowers in spikes; fruit subglobose or oval-oblong, white or pinkish. 
Morus nigra, Black Mulberry, small tree or shrub with cylindrical staminate spikes and oval pistillate spikes; fruit oval-oblong and black when mature.

Morus rubra, Red Mulberry, a tree with slender staminate spikes and droop. ing pistillate spikes; fruit cylindric and deep red or purplish.

Broussonetia papyrifera, Paper Mulberry, a low wide-spreading tree with diœcious flowers, the staminate in elongated spikes, the pistillate in heads; the globose fruit peduncled.

Toxylon pomiferum, Osage-Orange, an armed shrub or tree, dioecious, with the staminate flowers in globose racemes, the pistillate in dense heads; the oblong flat achenes collected into a large globose golden-yellow syncarp.

Ficus Carica, Fig, a shrub or mostly a small monœecious tree, with firm leathery leaves, palmately 5-7 lobed, on densely pubescent petioles; the flowers on the inside of a closed receptacle; fruit an obovoid syconium.

Ficus elastica and F. pandurata are the Rubber-Plants, cult. in tubs.

Ficus repens, a small-leaved, evergreen, shrubby climber.

Cecropia palmata, Shakewood tree, diøecious, has broad palmately 7-lobed leaves, silvery beneath, and finger-like fruit with minute seeds, similar to a fig.

\section{Ulmaceae, Elm Family.}

Mostly trees with spreading, often winged branches, and alternate simple leaves; flowers in cymes or clusters, perianth a green or slightly colored calyx; stamens usually as many as the sepals and opposite to them, disdinct; ovary 1-2 celled, superior; fruit a stalked samara or drupe.

1. Fruit a samara winged all around, - _ _ _ _ - Ulmus, Elm

U. Americana, White Elm. A tree with oval or ovate leaves, usually doubly serrate, oblique or cordate at the base; flowers clustered, calyx campanulate; samara oval or obovate, fringed, the tips strongly convergent; seed central, oval or elliptic. Low ground and planted. Winter or early Spring.

1. Fruit a drupe, - - - - - - - - - Celtis, Hackberry

C. Mississippiensis. A tree with thick, lanceolate, acuminate leaves; drupe dark-purple or deep-orange. Hammock. Spring.

\section{Polygonaceae, Buckwheat Family.}

Herbs, shrubs, trees (South Florida), or vines with simple, alternate, opposite or whorled leaves, mostly simple; stipules mostly present and usually forming sheaths; called ocreae; flowers perfect, monœcious, diøcious or polygamous in variously disposed clusters; calyx inferior of 2-6 sepals, more or less united; stamens $2-9$; ovary 1 -celled, styles 2-3, stigmas capitate or tufted or 2-cleft; fruit an achene.

1. Ocreae wanting,

1. Ocreae present,

2. Vines with tendrils at the ends of the branches, flowers in panicled 
racemes subtended by bracts; sepals 3 ; stamens 7-10. styles 3 . Brunnichia

B. cirrhosn, with altemate leaves; ocreae sometimes represented by a ring of short bairs. Riverbanks. Spring and summer.

2. Climbers with fowers in racemes which end in branching tendrils; sepais 5 , colored, the 2 interior ones narrower; stamens 8 ; styles

3.

A. leptotus, Rosa de Moniana, Mexican l'ine. Leaves cordate, acuminate; flowers rose-pink. Cultivated. Summer or Fall.

3. Shrubs or trees;-leaves alternate; flowers in spike-like racemes, green; sepals 5, stamens 8 , ovary superior, styles 3 . fruit an achene,

Coccolobus, Sea-grape

C. uvifera. Shrubs or small trees with the branches forming a head; leaves suborbicular, cordate at the base; the purple or greenish fruit forms a dense raceme, resembling a bunch of grapes. Close to the coast.

3. Herbs,

1. Sepals 6 ; stigmas tufted,

4. Sepals 5; stigmas not tufted,

5. Wild plants; stamens 6 , styles 3 ; - leaves alternate, ocreae thin and brittle; flowers green, in whorls disposed in panicles,

Rumex

R. acetosella, Sheep-sorrel. Leaves hastate, flowers dicecious, three inner sepa!s without wings; plants sour. Dry soil. Spring to Fall.

R. hastatulus, Doik. Leaves mostly hastate, flowers diøecious, inner sepals with wings; plants sour. Sandy soil. Spring.

R. verticillatus, Woler-dock. Leaves not hastate; wings of sepals broadly deitoid. undulate or shallowly toothed. In swamps. Summer.

R. crispus, Yellow doik. Stout plants with fusiform, yellow roots; leaves strongly crisped. Around dwellings. Summer.

5. Culvivated p'ants; stamens 9 or 6 ; styles 3 ; -calys white, sepals all similar flowers fasciculate in racemed panicles,

Rheum

R. Rhaponticum, Pie-planl, Rhubarb. Leaves very large, the petioles juicy and acid. Cultivated.

6. Twining vines; - leaves alternate; ocreae oblique, naked or fringed at the top or the base; flowers in loose racemes; calyx green or yellowish white, three of the sepals keeled or winged,

Tiniaria

T. (Polygonum) convolvulus, Black Bindweed. Calyx green, outer sepais keeled at maturity. In cultivated ground. Late Summer.

b. Herbs not twining.

7. Stems conspicuously jointed and striate;-leaves alternate; ocreae cylindrc; fowers on jointed pedicels; calys white or pink, three of the sepals usually winged. Summer and Fall, _ _ Polygonella

P. polygama (parvifiora) Jointweed. Branched near the base; calyx white or pinkisin; outer sepals reflexed. In sandy soil near the coast.

P. gracilis. Branched especially above; calyx white or pink; outer sepals not reflexed. Sandy soil

7. Stems not jointed, erect, or at the base ascending or decumbent:leaves alternate. lanceclate; ocreae mostly membranous, naked or bristiy. flowers in spike-like linear racemes; caly $\mathrm{x}$ white, greenish or pinkish; stamens 4-8. styles 2-3. Swampy places. Summer and Fall, - - - - - Persicaria (Polygonum), Smarweed

P. punctata (acre). Leaves acuminate, punctate; ocreae fringed; sepals punctate; stamens 8. 
P. hydropiperoides. Leaves acute, ciliate, ocreae fringed; stamens 8 .

P. lapathifolia (densiflora). Leaves and ocreae ciliate; stamens 6.

P. setacea. Leaves acuminate, strigose on both sides; ocreae strigose, fringed with bristles; stamens 8 .

P. hirsuta. Leaves cordate, acute; ocreae hispid, fringed with short bristles; stamens 8 or fewer.

\section{Chenopodiaceae, Goosefoot Family.}

More or less fleshy herbs, chiefly weed-like, or shrubby plants, rarely vines; leaves alternate or opposite, exstipulate; bracts not scarious; flowers greenish, sometimes single, mostly clustered; calyx of $2-5$ sepals; stamens as many as sepals or lobes, or less; ovary 1-celled, styles $2-5$ more or less united; fruit a utricle or an achene.

1. Herbs with leaves normal; flowers perfect or some of them pistillate,

calyx fleshy or herbaceous, and when mature without a wing.

Waste places, - - - - - - Chenopodium, Pigweed

C. album. Plant pale green; flower-clusters dense; sepals glaucous, keeled; seeds black, shining. Spring to Fall.

C. murale. Plant deep green; flower-clusters small; sepals slightly glaucous, not keeled; seeds not shining. Summer and Fall.

C. anthelminticum, Worm-seed. Plant aromatic; flower-clusters in elongated interrupted spikes; sepals glabrous; seeds smooth, shining. Summer and Fall.

2. Herbs or low shrubs with scaly pubescence, leaves normal; flowers diœcious or monœcious, pistillate flowers without a calyx; fruit enclosed in two bractlets,

Atriplex, Orache

A. arenaria. Fruiting bractlets united to above the middle.

A. cristata. Fruiting bractlets united only at the base; styles included. Both on the coast. Spring to Fall.

3. Fleshy, glabrous herbs with the leaves, reduced to scales or mere ridges, opposite at the numerous nodes; flowers perfect or polygamous, 3-7, in cavities at the joints.-Salicornia, Glasswort or Samphire

S. ambigua. Stem decumbent or trailing. On the coast. Summer and Fall.

S. herbacea. Stem erect, joints longer than thick. Coast.

S. mucronata. Stem erect, joints as long as thick. Coast.

Cultivated in this family are:

Beta vulgaris, Beet and Mangelwurtzel; with alternate leaves and fleshy roots; flowers perfect in panicled spikes; calyx 5-cleft, stamens 5, ovary half-inferior, stigmas 2.

Spinacia oleracia, Spinach or Spinage; dioecious plant, with broad, fleshy radical leaves, somewhat arrow or halberd-shaped; flowers in small, axillary clusters; stamens 4-5 in a 4-5 lobed calyx; ovary with 4-5 styles or stigmas in a 2-4 toothed, bractless calyx; the calyx enclosing the flattened achene becomes horny on the sides.

\section{Amaranthaceae, Amaranth Family.}

Coarse herbs, rarely shrubs, with exstipulate simple and entire leaves; inconspicuous flowers subtended by 
variously colored bracts, and collected into terminal or axillary inflorescences; calyx of $2-5$ herbaceous or corolloid sepals; stamens 5 or less, hypogynous, opposite to the sepals; staminodia sometimes present; ovary 1celled, with 1-5 stigmas; fruit a membranous utricle, rarely a berry.

1. Anthers 2-celled, filaments distinct, - _ - _ - - _ - 2

1. Anthers 1-celled, flaments united into a long tube;-leaves opposite. blades sessile; flowers subtended by 3 blackish bracts and sometimes with bractlets, in dense spikes arranged in panicles; calyx 5-cleft; stamens 5, style short or wanting, - - - - Froelichia

F. Flaridana, an erect or ascending. slender herb with few pubescent leaves; the calyz-tube with deeply toothed crests and minute tubercles; spikes at the top of the stem. In dry, sandy places. Spring to Fall.

2. Perianth present in all flowers;-herbs with alternate leaves, the blades flat, undulate or crisped; flowers subtended by 3 green. red or purplish bracts; sepals $2-5$, stamens $2-5$, styles or stigmas 2-3. Waste places. Summer and Fall. - _ - Amaranthus

A. hybridus, Pigweet. Upper flowers in dense, terminal, drooping spikes; sepals and stamens 5 .

A. spinosus, Spring Amaranih Stems with a pait of spines at each leaf-axil. spikes erect or nodding; sepals and stamens 5 .

A. albus, Tumble-weed. Flowers in small axillary clusters; sezals and stamens 3.

2. Perianth wanting in the pistillate flowers;-branching stems with alternate, petioled, narrow leaves; divecious flowers subtended by 1.3 bracts; whitish. staminate flowers with 5 mucronate sepals. and 5 distinct stamens; pistil with $2-5$ stigmas, - _ - Acaida

A. australis, Wota-hemp. a stout, smooth, somewhat fleshy berb, widely branching: the staminate flowers in slender spikes, panicled, leafy-bracted at the base, naked above. In marshes near the coast. Summer and Fail.

Cultivated is Celosia cristata, Cock's comb with crimson to waite flowers in spikes. bracts 3, sepals and stamens 5 . stigmas 2 or 3 .

60. Corrigiolaceae (Illecebraceae), Whitlow-wort Family.

Erect or creeping and tufted herbs, with opposite, stipulate, narrow leaves; flowers perfect but incomplete, in clustered or dichotomous cymes; sepals $4-5$, more or less united, white or green; petals none; stamens $4-5$ with slender filaments; pistil 1, with 1-celled superior ovary, and very short more or less united styles; fruit a utricle or an achene.

1. Sepals 5 united to the middle; 5 bristles, instead of petals, inserte 1 with 5 stamens on the margin of the calyx-disk; style slenter.

2-cleft. On dry, sandy soll. Summer and Fall. - - Siphongchia

S. Americam. Sepals dilated at the apex, white-tipped; style exserted.

S. pauciflora. Sepais dilated, white or broadiy white-margined; style incluted. 
1. Sepals and stamens 5 inserted at the base of the ovary; styles united to near the top,

Anychiastrum

A. (Paronychia) Baldwinii. With prostrate wiry branches at the base of the stem; sepals oval, 3-ridged, ciliate. Dry soil. Summer and Fall.

\section{Phytolaccaceae, Pokeweed Family.}

Herbs, shrubs or trees with alternate leaves and perfect or diøcious flowers collected in racemes or panicles, terminal or axillary; calyx of 4-5 distinct or partially united sepals; petals none; stamens 4-8, rarely more, distinct or united, inserted below the ovary; ovary 1 -several celled; stigmas various; fruit a berry.

1. Herbs or shrubs with thickish entire leaves without stipules, flowers in terminal racemes; calyx 3-bracted, 4-5 parted; stamens 5-25, but reduced to staminodia in the pistillate flowers; ovary superior, composed of 5-12 more or less united carpels; styles 5-12 distinct.

Phytolacca

P. decandra, Poke-weed, Pigeon-berry. Stem stout from a large poisonous Ioot, branched; racemes somewhat drooping with pink pedicels, calyx white or greenish, berries dark purple filled with a crimson juice. Waste places. Summer and Fall.

1. Shrubby herbs; leaves entire, with small caducous stipules; flowers in axillary racemes; sepals 4, corolla-like; stamens 4; ovary 1-celled, style curved, with a 2-lobed or capitate stigma. - _ _ Rivina

R. humilis. Racemes peduncled, loosely flowered; calyx rose-colored, berries mostly red. Summer.

\section{Allioniaceae (Nyctaginaceae), Fon:r O'clock Family.}

Herbs or shrubs with alternate or opposite, exstipulate, simple leaves, and regular flowers, often subtended by a conspicuous involucre; calyx usually corolla-like, campanulate, trumpet-shaped or tubular; corolla wanting; stamens 1-many; ovary 1-celled, superior, surrounded by the calyx-tube; style and stigma 1 , ovary solitary.

1. Herbs,

1. Shrubs or climbers, cultivated;-the rather inconspicuous funnelshaped flowers in threes, each subtended by a large colored bract.

Bougain villea

B. glabra, glabrous with rose-red bracts, distinctly veined;- - the variety Sanderiana has the bracts deeper colored and smaller.

B. spectabilis (speciosa), hairy with deep rose to purple bracts; - the variety lateritia has brick-red bracts.

2. Stamens exserted; wild plants; - with petioled opposite leaves; flowers small with minute bracts; calyx campanulate, 5-lobed; stamens 1-5, united at the base. Dry soil. Spring to Fall. - - - Boerhaavia

B. hirsuta. Stem branched; leaves ovate, mucronate, ciliate; flowers pink or purplish. 
B. erecta. Stem simple or branched; leaves ovate to deltoid-ovate, whitish below; flowers white to purple.

2. Stamens not exserted; cultivated plants;-erect, bushy, with ovate, acuminate leaves; flowers in clusters.

Mirabilis

M. jalapa. Plant glabrous; involucre containing only one flower, white and shades of red and yellow, either striped or not; opening in cloudy weather or in the afternoon (Four $0^{\circ}$ clock).

63. Basellaceae, Madeira-vine Family.

Somewhat succulent vines with alternate, often cordate leaves, and flowers in spike-like racemes; calyx of 2 sepals, corolla of 5 petals; stamens 5 , opposite the petals; ovary superior, 1-celled, with 3 distinct styles; fruit a utricle. Cultivated under the name of MADEIRA-vinE; blooming in Fall.

Boussingaultia baselloides, growing in waste places in South Florida and Texas; a glabrous climber with short-petioled, ovate leaves and greenish-white or maroon flowers in slender racemes, the petals longer than the sepals.

Aoredera scandens, growing in chaparral of South Texas; like the preceding. tut the sepals are broadly winged at maturity, and the pale petals are not longer than the sepals.

\section{Tetragoniaceae, Carpel-weed Family.}

Herbs, often succulent, sometimes shrubby, spreading; leaves opposite, simple; flowers axillary; calyx of 4-5 sepals, corolla wanting, stamens about 4-5; ovary superior or more or less inferior, 1-many celled, with styles or stigmas as many as there are cells; fruit a capsule.

1. Sepals 5 , with hom-like appendages; stamens perigynous; ovary $3-5$ celled, half-inferior; sty"les 3-5, distinct. On the sea-shore.

Surmmer to Pall. - - - - Sesuvium, Sea-Purslane

S. maritimum (pentandrum). Leaves spatulate, short petioled; flowers mostly solitary, sessile; stamens 5.

S. portulacastrum. Leaves oblong, clasping; flowers solitary, short pedicelled; sepals purple within; stamens numerous.

1. Sepais 5, with hyaline margias; stamens 3 or 5; ovary 3-5 celled, superior; styles 3 , distinct,

M. verticillata, Carpel-weed. Stems branching. prostrate; leaves in whoris of $4-\$$. spaitulate; stamens 3 ; seeds red, shining. Waste places. Summer.

65. Portulacaceae, Purslane Family.

Succulent herbs with alternate or opposite leaves and perfect, regular flowers; calyx of 2 deciduous sepals, corolla of 4-5 or more petals; stamens hypogynous, usually of the 
same number as the petals; ovary 1-celled, styles and stigmas 2-5; fruit a capsule.

Leaves with scarious or bristle-like stipules; flowers sometimes with an involucre; petals 4-6, fugacious; stamens 7-many; ovary partly or wholly inferior, style 3-8 parted. Dry soil. Summer., - Portulaca

P. pilosa. More or less villous; leaves numerous, linear-subulate; sepals narrowly oblong; corolla pink or purple; stamens 15-25.

P. oleracea, Purslane, Pusley. Leaves fleshy, cuneate or obovate; sepals acute, keeled; corolla yellow; stamens 8-12. Cultivated.

The latter species is also cultivated in pots in improved strains.-Another cultivated species is P. grandiflora, Rose-moss, with several bright-colored varieties.

\section{Alsinaceae, Chickweed Family.}

Herbs, sometimes shrubby at the base, with opposite, entire leaves; sepals $4-5$, persistent; petals $4-5$ or none; stamens twice as many as the sepals, or less; ovary 1-celled, rarely $2-5$ celled, and styles $2-5$; fruit a capsule.

1. Stipules present, forming a bristly mass; flowers in terminal clusters of 3-6; sepals and petals 5 each; stamens and styles 3 each. Pine-

land. Spring.

1. Stipules wanting; petals 2 -cleft or 2 -parted

2. Flowers in more or less open cymes; sepals 5 or 4 ; petals 5 or 4 , white;

stamens 10 or less, hypogynous; styles 3 or 4 ; capsules ovoid,

Alsine (Stellaria), Chickweed

A. media has petals shorter than sepals. All kinds of soil. Throughout the year.

A. Baldwinii (Stellaria prostrata) has petals longer than sepals. Moist soil. Spring.

2. Flowers in forking cymes; sepals 5 rarely 4 , and petals as many, white, notched or cleft above the middle; stamens 10 or less, styles as many as sepals and petals; capsules cylindrical, fluted. Along the roadside. Spring to Fall. Cerastium vulgatum, Mouse-ear Chickroed

\section{Caryophyllaceae, Pink Family.}

Erect herbs, enlarged at the nodes, with exstipulate, opposite leaves; flowers perfect; $4-5$ sepals united into a toothed tube; 4-5 petals with narrow claws; stamens twice as many as the petals; ovary 1-celled, styles 2-5; corolla, stamens and ovary are inserted on a columnar prolongation of the receptacle; fruit a capsule.

1. Styles 2,

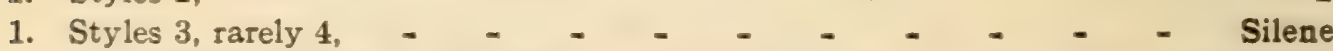

S. antirrhina, Sleepy Catchfly, with sticky patches on the upper internodes; leaves linear to elliptic; calyx-tube delicately ribbed; petals deeply notched at the apex, the tips white or pink; stamens 10. In fields. Early Summer.A very slender variety with much inflated calyx-tube is the $\mathbf{S}$. linaria.

1. Styles 5,

A. Githago, Corn Cockle, with forking stem and linear leaves; calyx-tube 10- 
ribbed; petals round or notched at the apex, purplish; stamens 10; the whole plant pubescent with long appressed hairs. In fields. Early Summer.

2. Flowers 5-parted, in cymes; petals with long claws and notched blades with an appendage at the base, _ _ - - - Saponaria

S. officinalis, Hedge-pink, Bouncing Bet. A stout herb with lanceolate to elliptic. leathery, often connate leaves; flowers in corymbed clusters; calyx-lobes white-margined; petals spatulate, white or rose, often double; stamens exserted. Waste places. Summer.

2. Flowers 5-parted; petals deeply colored, with long claws and toothed or eroded blades. Cultivated under the names of Pinks and

Carnations.

Dianthus

68. Ceratophyllaceae, Hornwort Famiy.

Submerged aquatic herbs with filiform, jointed, branching stems and finely dissected whorled leaves; flowers monœecious, axillary, sessile, inconspicuous; an involucre of 6-12 linear bracts takes the place of a perianth; sterile flowers with $12-24$ very short stamens, the anthers with a 2-3 toothed connective; ovary 1-celled with 1 ovule, style 1 ; fruit an achene.

Ceratophyllum demersum, Hornworl. Leaves rigid, 6-9 in a whorl, 2-cleft with spine-toothed segments; achene compressed, tipped with the style and armed near the base with a slender spine on each side.

\section{Ranunculaceae, Crowfoot Family.}

Herbs or climbing shrubs with an acrid sap; leaves simple or compound without stipules, but the base of the petiole of ten clasping or sheathing; flowers regular or irregular; sepals $3-15$, distinct, often colored, generally caducous; petals of about the same number, or wanting; stamens hypogynous, indefinite; ovaries 1-celled, distinct, numerous, rarely solitary; fruit an achene, follicle or berry.

1. Vines with opposite, 3-several foliate leaves; flowers mostly in dix-

cious paniculate cymes; sepals petaloid, petals wanting, stamen.

spreading, pistils several,

Few species cultivated, as C. paniculata, white.

1. Erect plants with sepals and petals each 5, ovaries 3-5; flowers soli-

tary, large, whise, red or purplish, single or double. Cultivated.

Paeonia, Peony.

70. Anonaceae, Cuslard-apple Family.

Shrubs (the ANova GLABRA of South Florida is a tree) usually with strong-scented bark and alternate entire leaves; flowers perfect; sepals 3 ; petals 6 in two series, 
the inner smaller or wanting; stamens numerous; ovaries few or many, distinct or cohering, berry-like in fruit.

Leaves deciduous, sepals valvate, petals imbricated; ovaries $3-15$ carpeled, tipped by a curved style; berries simple, 1 or more; seeds enclosed in a thin succulent aril imbedded in a yellowish pulp.

Asimina, Papaw

a. Flowers from the axils of present leaves,

a. Flowers appearing with or before the leaves,

b. Outer petals white or yellowish at maturity. Sandy pine-land. Early Summer. - - - - A. angustifolia (A. pygmaea, Dunal)

b. Outer petals dull black-purple at maturity. Dry pine-land. Early Summer. - - - - - - - A. pygmaea, Bartr.

c. Leaves leathery; young leaves densely tomentose on both sides, flowers yellowish white. Sandy pine-land. Spring.

A. speciosa (A. grandiflora)

c. Leaves membranous, flowers purple when mature,

d. Low shrub with gray to reddish bark; mature outer petals less than twice as long as the sepals. Dry sandy soil. Spring. A. parviflora

d. Tall shrub with dark gray bark; mature outer petals more than twice as long as the sepals. Riverbanks. Spring. - - A. triloba

\section{Magnoliaceae, Magnolia Family.}

Trees, shrubs or vines, often with aromatic bark; leaves alternate, stipules deciduous or wanting; flowers solitary, usually showy; calyx of 3 or more petaloid decidous sepals; corolla of 5 or more petals in 2 or more series; stamens 5 to numerous with adnate anthers; ovaries numerous in a whorl or imbricate on an elongated receptacle, 1-celled and 1-2 ovuled; fruit fleshy, baccate or samara-like, distinct or confluent in a conelike head.

1. Leaves entire, sometimes auricled at the base; fruit dehiscent or a berry, - 2

1. Leaves 4-lobed, fruit indehiscent, samara-like;-a large tree with deciduous truncate leaves and large deciduous stipules; flowers terminal, bell-shaped, greenish-yellow tinged with orange; sepals 3 reflexed; petals 6 erect; stamens and ovaries numerous; fruit a cone formed by the accrescent 1-2 seeded carpels. Low grounds, and planted. Early summer.

Liriodendron tulipifera, Tulip Tres or White Poplar

2. Ovaries in a single whorl, 1-ovuled, becoming follicles in fruit;-evergreen shrubs with alternate exstipulate leaves, and solitary flowers in the axils, sepals $3-6$ in 2 series, deciduous; petals in 3 -several series, deciduous; stamens numerous in several series; carpels 6-18 in a whorl, - - - - - - - Illicium, Anise-tree I. parviflorum. Corolla yellow, petals 6-12. Near the coast. Early Summer.

I. Floridanum. Corolla purple, petals 20-30. In swamps. Spring.

2. Ovaries imbricated in several series, 2-ovuled, - _ - - - 3

3. Shrubby vines with monoecious flowers;-alternate, exstipulate, deciduous leaves, and long-peduncled, mostly crimson flowers 
in the axils; sepals $5-6$ in 2 series, deciduous; petals $5-6$ in $1-2$ series. deciduous; stamens 5. united, forming a 5-lobed disk; ovaries numerous; fruit a spike of red berries on the much elongated receptacle. In woods. Early Summer.

Schizandra coccinea, Bay-slar Vine

3. Erect shrubs or trees with perfect flowers;-alternate stipulate leaves; flowers white, solitary, terminal; sepals 3 , deciduous; petals 6-12 in $2-4$ series; stamens numerous in many series; carpels numerous; fruit a cone of imbricated fleshy follicles tipped by the style or stigma; seeds scarlet, at length suspended by a thread. Our species are evergreens with coriaceous leaves.

M. grandiflora, Magnolia or Laurel Bay. A tall tree with leaves smooth and glossy above, rusty-pubescent below; flowers large, creamy white, fragrant. changing to brown. In hammocks and planted. Spring and Summer.

M. Virginiana (glauca), Sweet Boy. A shrub or slender tree; leaves glabrous above, glaucous below; flowers white, fragrant. In swamps. Early Summer.

Cultivated Magnolias with the flowers appearing before the leaves in Spring are:

M. Yulan (conspicua), a tree with large, white, sweet-scented flowers; sepals and petals almost alike.

M. obovata, a large shrub with large, scentless flowers, white inside and purplish to deep crimson outside; sepals small, greenish yellow.

M. Soulangiana, a bybrid of the preceding $t w o$, with flowers often fragrant and sepals usually colored; corolla white inside, pirk outside.

Closely allied to the genus Mognolic is:

Michelia (Magnolia) fuscata, Banara Shrub, an evergreen with small, banana. scented, brownish-yellow flowers; sepals and petals similar, 9-15 or more, in 3 or more series; stamens numerous; fruit a spike of leathery carpels; seeds as in Magnolia. Cultivated.

72. Cabombaceae, Water Shield Family.

Aquatic caulescent herbs with the foliage mucilage. coated; the submerged leaves dissected, the floating leavepeltate; the solitary small flowers on long axillary peduns cles, with a perianth of two whorls, each 3-,rarely 4-leavedIn ponds and slow-flowing water. Summer.

Cabomba Caroliniana. Flowers white, yellow or pink; stamens 6, pistils $2-4$. Brasenia purpurea (peltata). Flowers dull purple; stamens 12-18, pistils $4-3$.

\section{Nelumbonaceae, Lotus Fanily.}

Aquatic herbs with long creeping rootstocks and alternate concave peltate leaves on stout petioles; single showy flowers on stout scapes; perianth of numerous parts, hypogynous; stamens numerous; carpels imbedded in a 
fleshy receptacle; ovaries 1 -celled, ovule 1 , rarely 2 ; fruit consisting of several nuts in the accrescent receptacle.

Nelumbo lutea, Water Chinquapin. American Lotus. Flowers pale-yellow.

N. speciosa (nucifera), Indian Lotus. Flowers pink, fragrant. Cultivated.

74. Nymphaeaceae, Water Lily Family.

Aquatic acaulescent herbs with large rootstalks often tuber-bearing; alternate leaves with long petioles, those erect or floating leathery, those submersed membranous; flowers on long scapes; sepals 4-6; petals numerous, passing into stamens or staminodia; stamens numerous with adnate anthers; carpels several, more or less united into a compound ovary; stigmas united into a disk; fruit a leathery, many-seeded berry. Ponds, lakes and rivers. Summer.

1. Flowers yellow, erect at the ends of the scapes; sepals 5-6 leathery; petals 10-20 narrow; stamens hypogynous.

Nymphæa, (Nuphar), Spalterdock, Bonnets

N. sagittæfolia. Emersed leaves narrow, ovate, more or less sagittate, stigmatic disk with 11-15 lines. Ponds near the coast. Summer.

N. advena. Emersed leaves oval, more or less cordate; stigmatic disk with 12-24 lines. Ponds and lakes. Summer.

1. Flowers white, yellow, pink, floating at the ends of the peduncles; sepals 4 ; petals imbricated in series, numerous; stamens epigynous. - - - - Castalia (Nymphæa), Water or Pond-lily

C. (N.) odorata. Leaves with slender petioles; flowers 7-15 cm. broad, white or pink, fragrant.

C. reniformis. Leaves with thick petioles; flowers $18-25 \mathrm{~cm}$. broad, white, applescented.

C. (N) flava. Leaves with slender petioles; flowers 6-10 cm. broad, yellow.

\section{Papaveraceae, Poppy Family.}

Herbs, rarely shrubby, usually with colored sap; leaves mostly alternate, without stipules, entire or divided; flowers with 2-3 caducous sepals, 4-12 deciduous petals, numerous distinct stamens; ovary 1-celled, with parietal placentae; fruit a capsule, with numerous seeds.

Argemone Mexicana, Mexican Poppy. A spiny herb with yellow sap; leaves blotched with white, sessile or clasping, pinnatifid, spiny; sepals 2-3, hooded or horned; petals $4-8$ yellow; fruit spiny. Waste places. Spring to Fall.

A. alba, White Poppy. Stem stout, not pubescent; leaves pinnately-lobed or pinnatifid, whitish along the veins; midrib prickly; flowers peduncled; the horns of the sepals erect; petals white. Sandy soil. Spring and Summer.

76. Brassicaceae (Cruciferae), Mustard Family.

Herbs or shrubby plants with pungent watery sap, alternate exstipulate leaves, and regular hypogynous flowers 
in spikes, racemes or corymbs; sepals 4, petals 4 , with the spreading blades forming a cross; stamens 6 , four longer than the other two, or rarely 2 or 4 ; style simple or wanting: fruit a 2-celled pod, either long (silique), or broad and short (silicle), or separating transversely into joints (loment).

1. Fruit a silique, - - - - - - - - - - 2

1. Fruit a silicle - - - - - - - - - - - 5

1. Fruit a loment, - - - - - - - - - - - 6

2. Shique staiked;-leaves auricled, clasping; flowers white to purple in terminal corymbose racemes; petals with long serrulate claws. ovary staiked. style wanisg. Sandhills. Fall. - Warea amplexifolia

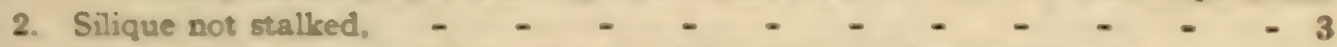

3. SLique flattened parallel to the hroad partition; valves with veins, fowers yellow;-plant grayish-white with pale hairs; leaves with twice pinnatifid blades on short petioles; flowers in racemes or panicles; ovary sessile, style short. Dry soil. Spring and Summer. - - Sophia pinnata (Sisymbrium canescens), Tansy-muslard

3. Silique terete or 4-angled, - - - - - - - - - - 4

4. Pods not beaked, tut pointed with the short style; valves 1-veined:leaves alternate; fowers in racemes, sepals 4 . petals 4 small or wanting. stamens 1-6, stigma 2-lobed; seeds in 2 rows, turgid, Roripa (Nasturtium)

R. Walteri (N. tanacetifolium), Waterress. Stems branching at the base; leaves bi-pinnatifid; flowers yeliow or white; pods sessile. Damp soil. Spring.

R. palustris. Marshcress. Stems erect. branching; leaves pinnatifid, clasping; flowers yellow or pa:e: puds pediceijed. Swampy soil. Summer.

4. Pcds proionged into a conic indehiscent beak; valves $1-3$ veined:stems more or iess widey branching. leaves lyrate-pinnatifid, upper leaves entire or toothed: flowers in racemes. petals brightyetiow, twrce as long as the sepais. In waste piaces or cuitivated ground.

B. nigra, Black muslard Upper leaves sessile.

B. campestris, .Turnip. Upper leaves clasping.

B. oleracea, with leaves fleshy, repand-toothed or lobed, to which the cabbage rarieties and bohlrabi belong.

5. Sixc!es fattened contrary to the narrow partition. orbicular or obovate, oruies scilitary in each ce.!:-stems simple or branched; basal leaves oblanceolate. pinnatifid; stem-leaves narrow; flowers white. in racemes or panicles; corcilia smail or wanting; stamens mostly
2. Waste places.
Lepidium Virginicum, Pepper-gress

5. Silicies fatiened para:.el to the broad partition. oval to suborbicular; cruies schitary in each ceil;-caulescent herbs with ascending of decumient more or less forked branches, and oblanceolate leaves; sma:l white fragrant fowers in terminal clusters or racemes. Cuitiva:ed. Koniga maritima (Alyssum odoratum), Sweel Alyssum

6. Loment 2-jonted, shor:- Ceshy annuais with entire or pinnatifid leaves and white to puryie flowers; the foints 1-celied, the upper 1-seeded, the iower 1-2 seedet. In drifting sand along the crast.

Cakile, Sea-rocket

C. Chapmanii (C. maritima var. equalis), Beach-sop. Upper joint ibucker thas the lower, both l-seeded. 
6. Loment, 2-jointed, elongated;-annuals or biennials from a thick root, with a cluster of lyrate leaves, and with pinkish flowers; pods 2-3 seeded. Cultivated for its root.

Raphanus sativus, Garden Radish

An interesting curiosity is the Anastatica Hierochuntica, the so-called Rose of Jericho.* Leaves obovate, flowers small, white, spicate; fruit a silicle with transverse partition, each cell with 1 seed. After flowering the leaves drop, the branches roll up into a ball, thus protecting the fruit near their tips. When later properly moistened, the branches straighten, the fruits open, and the seeds germinate quickly.

\section{Resedaceae, Mignonette Family.}

Herbs with alternate, entire or pinnate leaves and minute stipules; flowers small, 4-7 parted, in racemes or spikes, fragrant; stamens 8-many, inserted on the hypogynous, one-sided torus; pistil 1, ripening into a 3-6 horned capsule.

Reseda odorata, Mignonette. Spreading annual with spatulate or oblanceolate leaves; flowers yellowish-white in spicate racemes. Cultivated.

78. Droseraceae, Sundew Family.

Low marsh-herbs with alternate mostly radical leaves, circinate in vernation; the foliage covered with glandular hairs exuding a viscid secretion; flowers in spikes or racemes on scapes; sepals $4-8$, withering; petals $4-8$, white to purple; stamens $4-8$, usually 5 , anthers extrorse; ovary 1-celled, many ovuled, superior; styles $2-5$, distinct, entire or cleft; fruit a capsule, 1-celled, $2-5$ valved. Low pineland or mossy swamps around ponds and lakes. Spring and Summer.

Drosera, Sundere.

1. Leaves with blade and petiole, not filiform, - _ _ - - - - 2

1. Leaves filiform; - scapes smooth, erect; flowers bright purple, rarely white,

2. Blades suborbicular, shorter than the petioles; scapes smooth, erect;

flowers white, - $\quad$ - $\quad$ - $-\quad-\quad$ D. rotundifolia

2. Blades cuneate, longer than the petioles; scapes glandular-pilose,

erect; flowers white, - - - - - - - D. brevifolia

2. Blades spatulate, shorter than the petioles; scapes smooth, - - - - 3

3. Scapes erect, flowers pink, - _ - - - - - D. capillaris

3. Scapes decumbent, flowers white, - - - - - - D. intermedia

79. Sarraceniaceae, Pitcher-blant Family.

Acaulescent marsh-herbs; leaves hollow, pitcher- or trumpet-shaped, winged on one side, sticky and pubes-

* A member of the Compositae, the Asteriscus pygmæus is also called Rose of Jericho; the involucre closes over the fruits when dry, and retreats when moistened. Both are "Resurrection-plants." 
cent inside, with deflexed hairs; scapes erect, naked; flowers showy, solitary; calyx subtended by 3 bracts; sepals 5 , persistent; petals 5 , deciduous; stamens numerous, with very short filaments and introrse anthers; ovary $3-5$ celled, superior; styles united into a 5-angled peltate body, the projections recurved bearing the minute stigmas beneath; fruit a 5-valved capsule.

Low pine-land or sphagnum-swamps. Spring.

Sarracenia, Pilcher-plant or Trumpel-leaf

1. Flowers yellow; - leaves erect, broadly winged, upper pait with green and purple veins and white or yellowish blotches; lamina arching over the orifice of the tube, - - _ - - S. minor (variolaris)

1. Flowers reddish brown,

2. Leaves decumbent, tube club-shaped, broadly winged, upper part with white spots and purple veins; lamina incurved, inflated, subglobose, almost closing the tube, - - _ - S. psittacina

2. Leaves ascending, tube inflated, broadly winged, upper part purpleveined; lamina erect, reniform, - - - - - - S. purpurea

80. Sedaceae (Crassulaceae), Orpine Family.

Mostly succulent herbs with exstipulate, thick leaves; flowers perfect or diøecious, in cymes or panicles, or solitary; sepals $4-5$, or more or less; corolla of as many petals as there are sepals, sometimes united or wanting; stamens as many as petals or twice as many; ovary of as many carpels as there are sepals, distinct or united below; fruit a follicle.

Bryophyllum pinnatum (calycinum). A fleshy plant with shrubby base, the opposite leaves sometimes pinnately compound; the perfect flowers in showy panicles; the bladder-iike calyx of 4 sepals; the reddish corolla with 4 spreading lobes. -Found in waste places South, but here cultivated for the curious habit of the leaves sprouting when placed on sand or pinned on the wall.

Other cultivated plants of this family belong to the following genera:

Sedum, Stone-crop. polypetalous with sepals, petals and carpels 4 or 5 , and stamens twice as many.

Sempervivum, House-bek, polypetalous, with sepals, petals and carpels $6-20$, and stamens twice as many.

Crassula (Rochea) and Cotyledon (Echeveria), momopetalous, both with 5parted flowers, but the former with 5 , the latter with 10 stamens.

\section{Penthoraceae, Virginia Stonecrop Family.}

Herbs with firm but not fleshy tissues; the erect stems with alternate, thinnish, serrate leaves; flowers greenish in terminal cymes; sepals 5 ; petals 5 , small or wanting; stamens 10 , hypogynous, carpels 5 , united below, fruit a 5-celled capsule with the recurved styles persisting.

Penthorum sedoides. Dich Stonecrop. Stems erect with narrow bright green 
leaves; flowers greenish white, the petals usually wanting. Muddy places. Summer.

\section{Escalloniaceae, Hydrangea Family.}

Shrubs or vines with mostly opposite simple leaves and perfect flowers; calyx 4-10-toothed or parted; petals 4-10; stamens 8-many; ovary of 2-5 united carpels, styles rarely united; fruit a capsule.

1. Erect shrubs,

1. Shrubby vines;-evergreen, smooth, with elliptic leathery leaves and white flowers in terminal panicles; calyx 7-10 toothed, petals 7-10, stamens 20-30; ovary 5-10 celled, inferior, style thick, stigma 5-10 lobed. Riverbanks. Early Summer. - Decumaria barbara

2. Stamens $8-12$; - flowers perfect except some on the margin of the corymb or thyrse; calyx with 4-5 toothed border, or with 4-5 lobes in the sterile flowers; petals $4-5$; ovary $2-4$ celled, inferior; styles 2-4 distinct or slightly united below. Riverbanks. Summer.

H. quercifolia. Leaves deeply lobed, flowers in a thyrse.

H. Hortensis. Cult. species with nearly all flowers sterile, pink or blue.

2. Stamens 10, the alternate longer, filaments dilated and toothed;-flowers chiefly white, in panicles or racemes. Cultivated.

Varieties of De utzia scabra

2. Stamens $20-40$;-flowers white or cream-colored, solitary or in corymbs or racemes; calyx 4-5 parted; petals 4-5; styles mostly $3-5$, united at the base. Cultivated. - Philadelphus coronarius, Mock-Or ange

\section{Pittosporaceae, Pittospcrum Family.}

Evergreen shrubs with alternate, simple, entire leaves, the terminal ones in subverticillate rosettes; flowers solitary or umbellate or clustered in the axils of the terminal leaves; sepals 5 , distinct or coherent below; petals 5 , distinct or slightly coherent at the base; stamens 5 , alternate with the petals; ovary 1-celled, superior or nearly so, with 3 parietal placentae; 1 style and 1 stigma, 1-3 lobed; fruit a globular woody pod, 2-many seeded. Cultivated.

P. viridiflorum, Cape Pittosporum. Leaves obovate, obtuse or retuse; flowers in globose panicles, greenish yellow, jasmin-scented. Spring.

P. tobira, Japanese Pittosporum. Leaves obovate, dark green above, palegreen below; flowers in a terminal sessile umbel; white, fragrant. Spring.

84. Iteaceae, Virginia Willow Family.

Shrubs or trees with erect stems and alternate simple leaves; white flowers in terminal racemes or axillary panicles; calyx 5-cleft; petals 5 , with the tips inflexed; stamens 
5 ; ovary superior or nearly so; styles 2 , united; fruit an elongated capsule.

Itea Virginica, a shrub with pubescent leaves and twigs, and often drooping racemes. In or near swamps. Early Summer.

\section{Altingiaceae, Sweet Gum Family.}

Shrubs or trees with alternate simple leaves; perianth of 1 or 2 series, or wanting; stamens twice as many as the petals and half of them sterile, or numerous and the petals wanting; filaments distinct and anthers introrse; ovary of 2 partially united carpels; styles 2 , distinct; fruit a capsule.

Perianth wanting;-a tall tree with palmately-lobed, long-petioled leaves and caducous stipules; flowers monocious; the staminate heads in terminal racemes, sessile; the pistillate heads sulitary on long axillary peduncles; capsules with the horn-like styles united into a head; seeds 1 or 2 , winged. In low woods or planted.

Spring. - - - - Liquidamber styraciflua, Sweet Gum, Bilsted

\section{Platanaceae, Plane-tree Family.}

Large trees with alternate, palmately-lobed leaves and thin sheathing stipules; flowers monocious in dense peduncled heads, solitary or collected into spikes or racemes; staminate heads red, calyx and corolla of $3-6$ scales, stamens $3-6$, anthers elongated with long connectives; pistillate heads green, calyx and corolla $3-6$, usually 4 ; carpels as many as sepals, 1-celled, hairy; style awl-shaped, ovules 1-2; fruit an achene, surrounded by rigid hairs and crowded in dense globose heads.

Platanus occidentalis, Plane-lree, Bullon-ball (wrongly called Sycamore). Bark thin, white; leaves round-cordate, angularly lobed and toothed, woolly-pubescent when young, but soon smooth; heads solitary, pendulous. River-banks and planted. Spring.

\section{Rosaceae, Rose Family.}

Herbs, shrubs, vines or trees, mostly with alternate, stipulate leaves, and perfect flowers; calyx usually of 5 more or less united sepals accompanied by bracts; corolla of the same number of distinct petals, inserted with the stamens on the calyx-tube; corolla rarely wanting; stamens in one or more series, filaments distinct; carpels 1-many on a depressed or elongated receptacle; ovules 1,2 , or several in each cavity; fruit various.

1. Ovaries superior, fruit not enc! osed in the receptacle, _ _ _ _ $~ 2$

1. Ovanes inferior, fruit enclosed in the fleshy receptacle;-prickly 
shrubs with erect, trailing or climbing stems; leaves generally odd-pinnate, stipules adnate; flowers solitary or in corymbs, white, pink, yellow, or red; calyx 5-cleft, petals usually 5; stamens numerous, inserted with the petals on the throat of the calyx; pistils numerous,

a. Styles cohering, exserted;-a climbing or reclining shrub, leaflets 3-5; flowers showy, red, few in terminal corymbs. Borders of swamps or planted. Summer, R. setigera, Prairie Rose, Climbing Rose R. multiflora, Japan Rose, leaflets 5-9, is cultivated with varieties as Crimson Rambler, Seven Sisters, etc.

a. Styles distinct, included,

b. Sepals persistent; -an evergreen shrub with spreading stems and branches, and recurved prickles; leaflets 5-11, stipules bristle-fringed, caducous; flowers showy, white or creamy or yellow, solitary or few together with large bracts under the tomentose calyx. Planted in hedges and escaped. Summer.

R. bracteata, Macartney Rose

b. Sepals deciduous,

c. Leaves deciduous; - a bushy shrub with stout prickles; leaflets $5-9$, membranous, glaucous beneath; flowers red to white, in corymbs, rarely solitary. In swampy places. Summer.

R. Carolina, Swamp Rose

c. Leaves evergreen;-stems climbing and trailing, with short recurved prickles; leaflets mostly 3 ; flowers solitary, white. Planted and along roadsides. Spring. - - R. laevigata, Cherokee Rose

For the numerous species and hybrids see Bailey's Cyclopedia, art. Rose.

2. Calyx bractless; shrubs,

2. Calyx with 5 bractlets; herbs;-acaulescent, often with stolons; leaves long-petioled, 3-foliate; flowers in terminal cymes, calyx 5-parted, petals 5 white, stamens about 20 in 3 series, pistils many, fruit consisting of numerous achenes imbedded in or seated on the more or less elongated fleshy torus. Cultivated. Fragaria, Strawberry

3. Pistils rarely more than 5 , maturing into $2-4$ seeded follicles;- - flowers white or rose, in terminal or axillary umbels, corymbs or panicles; calyx 4-5 cleft, petals 4-5, stamons 20-60, follicles 5 . Cultivated. Early Spring. - - - - - Spiraea, Bridal Wreath

3. Pistils numerous, maturing into $\mathbf{1 - 2}$ seeded drupelets crowded on a convex or conic receptacle;-shrubs with erect or trailing stems, bristly or prickly; leaves lobed or compound, with stipules adnate to the petioles; calyx 5 , petals 5 , stamens numerous; drupelets smooth,

a. Petals erect; the coherent drupelets separating from the torus, Raspberry The Rubus flavus, Indian Raspberry, is sometimes planted.

a. Petals spreading; the coherent drupelets adhering to the torus when ripe,

b. Stem erect, ascending or recurved, - - - _ - Blackberry

Leaves 3-foliate or on the shoots 5-foliate; leaflets leathery. densely tomentose beneath, with stout prickly petioles; flowers few in terminal corymbs, white; fruit oblong, black. Sandy soil and planted. Spring.

R. cuneifolius, Sand Blackberry

b. Stem trailing or decumbent, 
snrub with prickles or bristles, the flowering branches erect; leaves 3-5 foitate, leaflets thickish; flowers large, usually soiltary, white; frut oblong, black. Sandy soil and planted. Spring.

R. trivialis, Soushern Dewberry

\section{Calycanthaceae, Strawberry Shrub Fumily.}

Aromatic shrubs with opposite exstipulate leaves, usually entire; flowers terminal, purplish or yellow, fragrant; sepals and petals numerous and alike, in many series inserted on the edge of the receptacle; stamens numerous inserted on the receptacle, the outer 5-12 fertile, the inner reduced to staminodia; anthers adnate, extrorse; carpels many, 1-seeded, distinct, included in the fleshy receptacle; fruit a capsule including few or many achenes.

Butneria florida (Calycanthus floridus). Sweet-scenled Shrub. Twigs and leaves pubescent, fowers short-peduncled, dull purple, fragrant. Cultivated. Late Spring.

\section{Malaceae, (Pomaceae), Apple Fumily.}

Trees and shrubs with alternate, pinnate or pinnatelyveined leaves and small deciduous stipules; flowers regular, solitary or in racemes or cymes; calyx 5-parted, adnate to the ovary; petals 5; stamens mostly numerous, distinct; carpels 1-5 wholly or partly united; ovary 1-5 celled with orules 1-2 in each cell; styles 1-5; fruit a pome, consisting of the thickened calyx-tube enclosing the bony, membranous or leathery carpels.

1. Carpels membranous or leathery at maturity; trees.

Styles 5. distinct; - tree with white flowers in terminal simple cymes;

fruit with grit-cells. LeConbe, Sondpear and Keifer are

cultivated. - - - - - - - Pyrus, Pear

Siyles 2-5. mostly united at the base:-tree with pinkish fowers.

in terminal simple çmes; fruit without grit-cells. - _ Malus, Apple

1. Carpels brny at maturity, 1-seeded, or if 2-seeded dissimilar;-shrubs or sma.i trees. mostly with spines or thoms; white or pinis flowers in terminal cymes or corymus; stamens $5-25$ in $1-3$ series, with cciored antbers; styles 1-3 distinct. Spring or early Summer.

Crataegus, Howihorn

a. Corymbs compound, many-flowered;-leaves ovate-lanceviate, Eisipic or obrvate, contracted or on the showts rounded at the base; iwigs very spany; mature frust red to urang-red, $5-5 \mathrm{~mm}$. Riverbanks.

C. paludosa

a. Corymus simple. $2-5$ flowered, or flowers solitary. - ruptiy contracted bases; anthers purple; mature frutt red. o-12 mon. Riverbaaks. 
b. Leaves spatulate or cuneiform, on the shoots ovate or obovate with cuneate or narrowed bases; anthers purple; mature fruit orange-red, 8-10 mm. Swampy woods.

C. luculenta

b. Leaves spatulate or cuneate; anthers yellow; mature fruit orange or red, 6-8 mm. Banks of St. John's. - - - C. anisophylla

A genus of ornamental shrubs is Photinia with flowers in corymbs or panicles,petals 5, orbicular; stamens 10-20; styles 2, rarely 3-4; fruit a small 1-2 seeded pome, red or scarlet.

P. serrulata. Evergreen; flowers white in panicles; stamens 20; fruit red. Spring.

Allied with this genus is the Eriobotrya (Photinia) Japonica, Loquat or Japan Plum, a small tree with large white fragrant flowers in a terminal woolly cluster; calyx 5-toothed, thick; petals 3, crenulate; ovary 3-5 celled, each cell 1-ovuled; fruit a yellow pome with large seeds. Late Summer and Fall. Cultivated for ornament as well as for fruit.

\section{Amygdalaceae, Plum Family.}

Shrubs or trees with alternate simple leaves and deciduous stipules; flowers in clusters, corymbs or racemes; calyx 5-parted, free from the ovary; corolla of 5 distinct petals together with numerous stamens inserted on the calyx-tube; carpels 1 , rarely $2-3$; ovary 1 -celled, 2 -ovuled; style 1; fruit a drupe, seed solitary.

1. Style arising from the base of the ovary;-leaves leathery, glossy; flowers small, white or greenish in terminal cymes, drupe pulpy.

Late Spring. - - - - Geobalanus, Gopher apple, Ground oak

G. oblongifolius, A low shrub in wide patches; leaves glabrous; drupe ovoid to obovoid. Dry sandy pine-land, and dunes.

G. pallidus. A low shrub in wide patches; upper leaves white-tomentose beneath; drupe subglobose. Pine-land.

1. Style terminal,

2. Leaves deciduous; flowers in clusters or terminal racemes; drupe mostly pulpy,

2. Evergreens; flowers in axillary racemes shorter than the leaves; drupe dry;-leaves leathery, glossy; flowers small, white, - Laurocerasus

L. Caroliniana, Cherry-laurel. A tree or shrub; drupes black, lustrous. Riverbanks or planted as trees or in hedges. Early Spring.

3. Flowers sessile or nearly so; endocarp (stone) wrinkled and pitted;shrubs or trees with the flowers appearing before the leaves; corolla pink or white, - _ - - _ - - Amygdalus

A. Persica, Peach. Foliage and flowers fragrant, petals and usually the filaments pink; drupe soft-velvety, stone bony. Waste places, and planted in some varieties as Angel, Hall, Jewell, etc.

3. Flowers peduncled; stone smooth,

4. 'Flowers in lateral corymbs or clusters, appearing before the leaves; shrubs or trees, sometimes thorny; flowers white or pink; drupe pulpy; stone bony. Spring.

P. Americana, Wild Plum. Small tree with thick, sharply serrate leaves; flow. ers in lateral umbel-like clusters; sepals entire; drupe subglobose, reddish, sometimes with a slight bloom. In woods. 
P. ambellata, Hog Plum. Black Sloe, Bullace Pluw. Snall tree or shru's with thinnish, serrate leaves; sepals pubeseent insule; drupe gl jose, nearly black beneath the bloom. Low pins-land or hamarasis.

P. angustifolia, Chickasase Plum. Somaxhat spiay shrub): leavas thinnish, serru late; sepals ciliate with glanilular hairs; drupe ova!-glj'jose. red or yellowish, with a slight bloom. Thickets.

The Chickasaw is also planted, as are Kelsey, Wickson, etc.

4. Flowers in terminal racemes, appearing after the leaves;-3hru bs or trees, flowers white; drupe pulpy; stone bony,

- Padus

P. serotina, Wild Cherry, Black Cherry. Tree with firm, glabrisus leaves, finely serrate, with the teeth callous an 1 appressed; drupe purpish blac's. Wouls and planted. Spring.

To the cultivated species of this family, though not often planted here, belong the Cherrics (Cerasus). Apricols (Armeniaca) and Almonds (Amygdalus).

\section{Mimosaceae, Mimosa Family.}

Herbs, trees and shrubs with erect or prostrate stems, and alternate mostly 2-3 pinnate leaves; stipules various, sometimes spine-like; flowers perfect or polygamous; sepals and petals 3-6, partially united or the latter distinct; stamens as many or twice as many as there are petals, or more, usually exserted, distinct or monadelphous; ovary superior, 1-celled; style 1; fruit a legume.

1. Stamens numerous, flaments distinct or the inner ones slightly united at the base,

1. Stamens as many or twice as many as the petals, - _ _ _ _ - 3

2. Peta's distinct or united below the midile; legumes flat.dry; - jrnamental shrubs or trees with leaves 2 -pinnate or reduced to phyiludes; the yellow flowers in spikes or heads on axilary peduncles; cal $5 \times$ 4-5 lobed or wanting; petals 4-5.

Acacia

2. Petais united into a tubular-funnelshaped corolla; legumes cylindric. pulpy within;- - rnamental shrujs or sma!l trees, spiny, with 2-pinnate leaves; the jellow flowers in globular splkis; calys and corolla shäiowly 5-lobed, - Vachellia (Acacia) Farnesiana, ()p pa nax

2. Petals united into a funnelshaped corolla; legumes broadly linear, fat:ornamental shrubs or trees, not spiny, with 2-pinnate leaves of $16-2 t$ pinnae; the pink flowers in panicles or caputate spikes; calyx and corolla 5-lobod; stameas numerous, erserted.

Albizzia Julibrissia, Mimosa-tree

3. Pods 4 -angled or with a broad margin. not jointed, beaked; -herbs or low shrubs with prostrate pricily stems; the sunstuve leaves 2-pinnate with setaceous stipels; purple flowers in axillary hea 1lise sprices; calyx and corolia $\$-5$ lujed. stamens $y-11$. Di; sandy soll. Summer.

Morongia (Schrankia), Sensube Briar

M. ancinata, with the leaflets prominently veined.

M. angustata, with the leaflets scarcely veined.

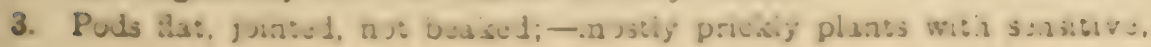


2-pinnate leaves; the white or pink flowers in axillary spikes; calyx and corolla 4-5 lobed, the former minute; stamens 4-10,

Mimosa, Sensitive Plant

M. strigillosa, prostrate herb with long petioles and peduncles, flowers pink. Riverbanks. Summer.

\section{Cassiaceae, Senna Family.}

Trees, shrubs and herbs with alternate, often stipulate leaves and mostly perfect flowers; calyx of 5 more or less united sepals; corolla of 5 petals, the upper one enclosed by the lateral ones in the bud; stamens 10 or less, with distinct or united filaments; ovary 1-celled, style 1 , ovules 1-many; fruit a legume.

1. Leaves entire or 2-lobed, the petiole prolonged into a short awn between the leaves; - a shrub or small tree cultivated for its large, almost regular, very showy flowers, - - Bauhinia, Mountain Ebony

B. purpurea has purplish petals, one of them streaked with white. Spring.

B. triandra, with pink flowers. Autumn.

B. alba and B. accuminata have white flowers. Early Spring.

1. Leaves even-pinnate,

1. Leaves bi-pinnate,

2. Calyz-lobes obtuse, corolla almost regular;-petioles with 1-several glands, stipules deciduous; the yellow flowers in terminal or axillary panicles or racemes; stamens 5 or 10, all normal or 3 of them reduced to staminodia; filaments unequal, - - Cassia, Senna

C. occidentalis. A stout branching annual; stipules filiform, caducous; leaflets $8-12$, with 2 petiolar glands between the lower pairs; flower large; legume linear. Waste places. Summer.

2. Calyx-lobes acuminate, corolla irregular;-petioles bearing 1 , rarely 2 glands near the base; stipules persistent; the yellow flowers solitary or clustered; stamens 10 , or some of them reduced to staminodia; filaments short, - - - Chamaecrista, Sensitive Pea

C. Chamaecristoides. Stems low and spreading, somewhat pubescent; leaflets 12-36; petiolar gland small, round; flowers solitary on filiform peduncles; calyx-lobes linear, ciliate; petals large. Dry ground. Summer.

C. aspera. Stems tall, erect, hispid with fulvous hairs; leaflets 40-50; petiolar gland slendtr; peduncles 2-3 flowered, very short. Waste ground. Summer.

3. Flowers dioecious or polygamous, small, greenish, in axillary or lateral racemes;--sepals and petals $3-5$; stamens $6-10$, filaments distinct; pod flattened, more or less curved, - - - - Gleditschia

G. triacanthus, Honey-locust. A tree armed with branching thorns; leaves numerous with 12-28 leaflets; staminate racemes solitary or clustered; pods long, black, twisted; seeds numerous. Spring.

3. Flowers perfect, showy,

4. Flowers in racemes or panicles; calyz-lobes 5 , petaloid, the lower lobe overlapping the other ones; petals 5 , unequal, highly colored; stamens 10, with distinct filaments, pods narrow, nearly straight, Cultivated. Summer. 
P. (Caesalpinia) pulcherrima, Duar! Pornione. Shrub with fow, sarterect frickles and deicate leaves, the larger with 6-18 pinnae and re'alweiy few leaflets; fowers terminal. retals crisped, orange-red, rarely yellow; stamens and style red, exserted. P'ants from South Flonda. somewhat hardy here.The species C. Japonica with ficwers in panicle-like clusters, canary-yellow, stamens red, is hardier.

4. Peticles very short, with $2-4$ branches carrying 5(-6) pairs of leafets; fowers in slender axillary racemes, bright yellow; the largest of the 5 petals with a gland at its base; stamens 10 , with distinct filaments; pods narrow turulose.

P. aculeat Jorusalcm Thurn* Shrub of small tree, with pendulous, thora branches; racemes slender, solitary or fascicled. Cult. Late Spring.

\section{Fabaceae (Papilionaceae), Pea Family.}

Herbs, shrubs, vines or trees with alternate, stipulate, mostly compound leaves and hypogynous or perigynous flowers, solitary or in inflorescences; calyx 4 or 5 lobed, sometimes 2-lipped; corolla of 5 petals viz: an upper one surrounding the rest in the bud, called VEXILLCM Or STANDARD, 2 lateral ones, WINGS, and 2 united or cohering forming the KEEL (wings and keel are rarely wanting, as in genus Amorpha); stamens 10 , sometimes 9 , rarely 5 ; filaments monadelphous, diadelphous or distinct; ovary superior, 1-celled or 2-several celled by cross-partitions; fruit a pod, legume or loment.

1. Stamens 10, distinct, - - - - - - - - - - 2

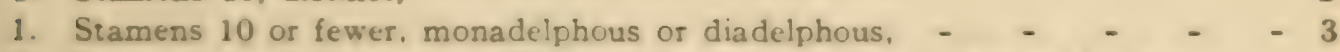

2. Leaves pinnate. pods moniliform;-shrubs or trees; leaves odd-pinnate with minute deciduous stipules; white, yellow or vislet ficwers in terminal or axiilary racemes or panicles, _ _ _ Sophora

S. Japonica, Pagoda-bree. An ornamental deciduous tree, flowers white or cream-colored.

S. tomentosa. A shrub with tomentose foliage, leaflets leathery; long racemes of yellow flowers. Near the coast. Summer.

2. Leaves 3-foliate or simple, pods infiated;-rect herbs with forwers in terminal or lateral racemes, or axillary; calyx-lobes nearly exual or the upper two united. - _ _ - Baptisia, Wild Indigo

B. calycosa. Leaves infoliate; fowers in racemes. yellow; calyx-lubes spatulate. longer than the tube. Sandy pine-land. Spring.

B. Lanceolata. Leaves trifohate, leaflets ublanceulate; fluwers axiliary, yelluw. Dry pine-land. Spring.

3. Leaves without tendrils,

3. Leaves with tendriis; style round-filform;-trailing or climbing herbs with even-pinnate leaves and fowers in racemes; vexilium hroal

- Zizyphus paliuris (Paliurus aculeatus) and Zizyphus Spina-Christi, Leiongmk 2. the Rhamnaceae, are also called Jerusalem 1 horn; they rexentile eath other very clusely, and one of them is supjosed in have furnisherl the therny coown of Cirist. 
and wings cohering to the middle of the shorter keel,

- Vicia, .Vetch

V. acutifolia. Leaflets $2-6$, linear; racemes $4-8$ flowered; flowers pale-blue, vexillum tipped with purple. Sandy soil, near the coast. Spring to Fall.

V. Floridana. Leaflets 4-6, oblong; peduncles 2-5 flowered; flowers white or pale-blue, keel and banner with a violet streak. Sandy soil. Spring to Fall.

Two cultivated species belong here:

Pisum sativum, Common Pea. Leaflets usually 4, peduncles several flowered; style dilated above and grooved on the back.

Lathyrus odoratus, Sweet Pea. Leaflets 2, peduncles 2-flowered, large, fragrant; style flat, dilated above, ascending.

4. Herbs, shrubs, trees or woody vines, - - - - - - - - 5

4. Herbs or herbaceous vines, - - - - - - - - - 23

5. Fruit 2-valved or indehiscent, not a loment, - - - - - 6

5. Fruit a loment,

6. Foliage not glandular-dotted,

6. Foliage glandular-dotted,

7. Stamens monadelphous, anthers of two kinds, - _ - - - - 8

7. Stamens diadelphous at least beyond the middie, anthers all alike.

(See genera Indigofera and Cracca). - - - - . -

8. Upper stipules decurrent; calyx 5-lobed; pods inflated;-low herbs with simple leaves; flowers in racemes or solitary; seeds loose in the mature pod. Dry soil. Spring to Fall. - Crotalaria, Rattle-box

C. rotundifolia. Pubescent; leaflets orbicular to oval; stems tufted, spreading.

C. Purshii. Slightly pubescent; leaflets linear, oblanceolate and spatulate; stems slender, more or less tufted, with short appressed hairs.

8. Stipules not decurrent; calyx 2-lipped; pods flat;-ascending or prostrate herbs with palmately 5-15 foliate, or simple, rarely 3 -foliate leaves, and flowers in terminal racemes,

Lupinus, Lupine

L. diffusus. Densely silky; leaves simple, mucronate; flowers blue with a purple or white blotch on the vexillum. Dry pine-land. Spring.

L. villosus. Densely villous; leaves simple, acute; flowers pale-red with a purple biotch on the vexillum. Dry pine-land. Spring.

9. Leaves trifoliate,

9. Leaves pinnate, pods dehiscent,

10. Pods straight; - herbs with erect or creeping stems; flowers mostly in heads; calyx-lobes slender and equal, or broad and the upper two united; pod flat or terete, and included in the persistent corolla, - - - - - - - - - Trifolium, Clover

T. pratense, Red Clover. Erect or ascending; pubescent; leaflets oblong to oval or ovate, often blotched; calyx villous, lobes filiform; corolla red, purple or white. Cultivated grounds. Spring to Fall.

T. repens, White Clover. Prostrate; smooth; leaflets obovate or roundish; calyx smooth, lobes short; corolla white, vexillum much longer than wings and keel. Roadside. Spring to Winter.

10. Pods curved or coiled;-herbaceous or shrubby, erect or prostrate; flowers in elongated or head-like peduncled racemes; calyx-lobes nearly equal, slender,

Medicago, Medic

M. Iupulina. Prostrate; flowers yellow; pod 1-seeded, smooth. Waste places.

M. sativa, Lucerne Clover, Alfalfa. Erect; leaflets oblong-lanceolate or obo- 
vate, dentate towards the apex; flowers purple to blue; pods pubescent. Cultivated. Spring to Fall.

11. Leaves odd-pinnate,

11. Leaves even-pinnate,

12. Shrubs or small trees;-partially villous; leaflets $9-11$; flowers large.

blue, in terminal panicles; stamens 5 , short, inserted on the calys; style incurved, seed red with a black blotch. Plant tender. Summer.

Ormosia dasycarpa, Necklace-tree

12. Trees; - with glabrous foliage and spiny stipules; leaflets 9-19; drooping racemes of white flowers with a yellow spot on the standard; pods flat. glabrous. Cultivated. - - - Robinia pseudacacia, Locust

12. Woody vines;-blue, purplish or white flowers in terminal racemes; calyx slightly 2-lipped, the upper two lobes partially united: vexillum broad, abruptly contracted into a claw with two appendages at the top. Ornamental vines. Spring,

- Bradleia (Wistaria)

13. Pods 4-angled or very turgid;-flowers in axillary spikes or racemes; calyx-lobes nearly equal; stamens monadelphous or one partially distinct, - - - - - - - Indigofera, Irdigo-plant

1. Caroliniana. Erect, tall; racemes longer than the subtending leal-like bracts; corolla yellowish-brown. Dry pine-land. Spring and Summer.

I. leptosepala. Erect, branches decumbent; racemes longer than the leaf-like bracts; corolla pale-scarlet. Dry soil. Summer.

I. tinctoria. Erect; racemes shorter than the leaf-like bracts; corolla rose or purplish; pods torulose. Waste places; formerly cultivated. Summer.

13. Pods turgid with prominent upper suture, obcordate in cross-section; herbs. In sandy pine-land. Spring. - _ - Tium (Astragalus)

T. intonsum (A. villosus). Ascending or prostrate, villous; leafets $9-15$, obo. vate or roundish; racemes ovoid, short; calyx pubescent; corvila dull yellow; pods villous.

T. obcordatum (A. obcordatus). Ascending or prostrate, giabrous; leaflets 15-25, obcordate; racemes ovoid to cylindric, short; calyx sumewhat pubescent; corolla pale-purple or blue, pods crescent-shaped. glajrous.

13. Pods flattened; -herbs or shrubs with long tough roots; flowers in racemes; calyx-lobes nearly equal, or the upper two united and shorter; stamens diadelphous or monadelphous. In sandy soil and pine-land. Summer. - Cracca, (Tephrosia), Cab-gub. Gous's Rue

C. ambigua. Trailing or assurgent, forked-branching; leaflets 7-11, linearoblong to obovate, often with reddish veins bentath; fritoles longer than the leaflets; corolla white or purple.

C. spicata. Decumbent or ascending; foliage villous; leaflets 5-15. oval or oblong. mucronate, the terminal ones obovate; calyx villuss; corulla white, turning purple in fading.

C. chrysophylla. Prostrate, forked-branching; leaves sessile or nearly so; leaflets 37. the lateral ones obuvate, the terminal one longest; calyx-lobes longer than the tubo; corolla whitish, turning purple.

14. Pods wingleas, more or less compressed.

14. Puds t-sided and t-winged:-Hiwers in axillary racemes, shorter than the leaves; calyx wih minute lo'ses; vexullum broad; wnys and keel almost alike. 
D. punicea. A small ornamental tree with orange-red or scarlet flowers. Summer or Spring.

15. Pods several-seeded, with thick margins;-tall herbs with flowers in axillary racemes; calyx 2-bracted, equally 5-toothed; vexillum broad, wings curved, keel blunt,

Sesbania

S. macrocarpa. Leaflets 20-70, oblong; racemes shorter than the leaves; calyx membranous; corolla yellow, spotted with purple. Moist soil. Summer and Fall.

15. Pods 2-seeded, with thin margins;-tall herbs with flowers in axillary racemes; calyx 5-toothed; vexillum reniform, keel-petals coherent above the middle; pod with outer and inner walls distinct,

G. vesicarium (Floridanum), Coffee-Bean. Leaflets 25-50, mucronate; racemes shorter than the leaves; corolla yellow.-A variety, atrorubrum has blackpurple corolla.

16. Leaves palmately 3-7 foliate or pinnately 3 -foliate; -herbs or shrubs with flowers in axillary peduncled spikes or racemes; calyxlobes equal or the lower longer; vexillum broad, keel short; pod broad. Sandy pine-land. Spring and Summer. - _ Psoralea

P. lupinellus. Leaves palmately 5-7 foliate, leaflets linear; racemes shorter than the peduncles; corolla blue or violet; pods lunate with curved beak.

P. canescens. Leaflets 3 , or on the upper leaves 1 , oval to roundish; racemes longer than the leaves; calyx-tube inflated on the upper side; corolla blue, turning greenish; pods with straight beak.

P. pedunculata (melilotoides). Leaflets 3, lanceolate; peduncles 2-3 times as long as the leaves and longer than the racemes; upper calyx-lobes lanceolate; corolla purplish; pods roundish.

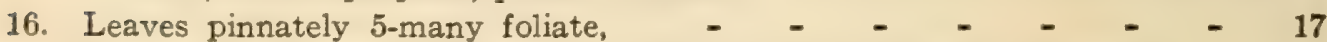

17. Stamens 10, corolla consisting of a single petal (vexillum); - shrubs with small flowers in spike-like racemes; calyx 5-lobed; stamens united at the base, exserted, - _ _ - - _ - Amorpha

A. herbacea. Grayish-pubescent low shrub with purple branches; leaflets 11-37, elliptic or oblong; racemes clustered; calyx-lobes short, unequal; vexillum broadly-spatulate, surrounding the stamens, white or bluish to violet-purple; pod small, with a slender nearly erect beak, glandular. Sandy soil. Spring.

A. fruticosa. Young plants tomentose; leaflets 11-25, oval or oblong; racemes clustered; calyx-lobes unequal; vexillum round-ovate, blue; pod curved, marked with large glands. Riverbanks. Early Summer.

17. Stamens 5, monadelphous, - - - - - - - - 18

18. Calyx-lobes shorter than the tube; spikes without involucre;-vexillum broad; wings and keel similar, - Petalostemon, Prairie-clover

P. carneus. Glabrous, much-branched herbs; leaflets 5-7, linear; corolla white or pink; spikes mostly cylindric; bracts lanceolate. Dry sandy soil. Summer.

P. Feayi. Glabrous, branched especially above; leaflets 3-7, linear; corolla lavender; spikes subglobose; bracts inconspicuous. Sandy soil. Summer.

18. Calyx-lobes longer than the tube; spikes with involucre;-flowers in corymbose spikes; calyx pubescent, lobes bristle-like; vexillum broad; wings and keel similar, their claws adnate to the

K. pinnata (Petalostemon corymbosum. Leaflets $3-15$, linear; spikes resemb- 
ling hesds; corolla white. Dry sandy soil. Summer.

19. Corolla yellow.

19. Corolla not yellow,

20. Flowers of two kinds; one kind complete but sterile, the other without calyx, corolla and stamens, but fertile; - rigid herbs with bristly or sticky-pubescent foliage; leaflets 3 . prominently veined; flowers in spikes or heads; calyx 2-lipped; stamens monadelphous; sty?le filiform; loment 2-jointed, the lower joint empty.

Stylosanthes, Pencil-flower

S. biflora (hispida). Pubescent in lines or hispid; stipules sheathing; spikes 3-4 flowered. Sandy pine-land. Summer.

20. Flowers perfect.

21. Leaves 4 -foliate; - erect or prostrate herbs; flowers in conspicunusly bracted spikes; calyx 2-lipped, 5-cleft or toothed; claw or vexillum broad; wings oblique, shorter than the keel; stamens monadelphous, anthers alternately longer and attached at the base, and shorter and versatile; style filiform; loment flat, several-jointed.

Zornia

Z. bracteata (tetraphylla). Peduncles longer than the leaves; bracts ovate and auricled; spikes 3-9 flowered; vexillum a hooded blade on a slender claw; loment 3-4 jointed. Sandy soil. Spring and Summer.

21. Leaves odd-pinnate;-flowers in racemes or panicles; calyx more or less two-lipped; corolla with a broad standard, and curved keel; stamens diadelphous in two groups of 5 , anthers alike; style incurved; loment flat, 2 or more jointed, Aeschynomene, Joint-retch

A. viscidula. Prostrate perennial; leaflets 5-9; peduncles few flowered; pods 2-3 jointed, joints half-orbicular. Sandy ground near the coast. Summer and Fall.

A. virginica (hispida). Erect annual; leaflets numerous; peduncles several flowered; pods 6-10 jointed, joints nearly square. Swampy soil. Summer.

22. Leaflets stipellate; loments of 2-more joints;-chiefly branching herbs with pinnately-trifoliate stipulate leaves; flowers in racemes and panicles; calyx bracted, 2-lipped, the upper lip emarginate or entire, the lower 3-cleft; stamens diadelphous or nearly so; loment 2-6 jointed. Summer and Fall.

Meibomia (Desmodium), Tick-trefoil, Begsar's licks

a. Leaflets linear, - _ - _ - _ - _ - - - b

a. Leaflets not linear. - _ - _ - _ - _ - - c

b. Joints of the loment triangular;-stem erect, finally pubescent; stipule setaceous, deciduous; corolla purplish; loments 2-3 jointed, joints small, with straight or depressed backs. Pine-

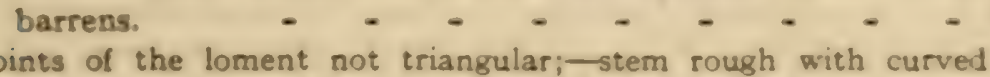

b. Joints of the loment not triangular;-stem rough with curved
hairs; stipules caducous; corolla pinkish purple; loment 2-3 jointed, joints rounded. Pine land, - _ _ - M. tenuifolia

c. Stem trailing or reclining;-stipules persistent, subulate; leaflets suborbicular; corolla purplish; loment $2-4$ jointed, joints nearly oval. Sandy soil, - - - - M. arenicola (D. lineatum)

c. Stem erect or ascending. - _ - _ _ _ _ - - d

d. Foliage pubescent; -stipules lanceolate; leaflets scabrous above villous or tomentose beneath; corolla pale purple, turnug green; lomeat $2-4$ jointed. jorats balf-rbombic. Woods. M. viridilar 3 
d. Foliage glabrous, often glaucous; - stipules caducous; leaflets ovate paler beneath; corolla blue-purple; loment 3-6 or more jointed, joints half-rhombic. Pine-land.

\section{M. laevigata (D. rhombifolium)}

22. Leaflets not stipellate, loments of 1-2 joints;-herbs with pinnately trifoliate leaves and mucronate stipules; the small flowers in racemes or spikes; calyx bracted, 5-cleft, with subulate teeth; stamens diadelphous; loments small, joints lenticular, prominently veined. Dry sandy soil. Summer and Fall.

Lespedeza, Bush-clover

L. hirta. Stem erect or ascending; flowers all complete and fertile; corolla yellowish white and vexillum of ten with a purple spot; peduncles longer than the leaves.

L. capitata. Much like the preceding; peduncles shorter than the leaves.

23. Keel of the corolla neither coiled nor curved, - _ - - - - 24

23. Keel of the corolla coiled or curved, - - - - - - - -29

24. Style smooth or sparingly pubescent below, - - - - - - 25

24. Style bearded along the inner side;-herbs with erect or slightly twining stems; leaves pinnately 3-many foliate, with stipules; flowers showy, solitary in the axils, or in racemes; calyx 5-toothed, longer than broad; vexillum large, notched at the apex; wings curved; keel shorter than the wings; stamens diadelphous, or monadelphous below; pod narrow, - - - Clitoria, Butterfly-pea

C. Mariana. Peduncles shorter than the petioles; corolla lilac or pale blue, vexillum striped with magenta near the center. Sandy soil. Spring and Summer.

25. Vexillum not spurred at the base, - - - - - - - -27

25. Vexillum spurred at the base, - - - - - - - - - 26

26. Herbs with prostrate or climbing stems; leaves pinnately 3-or 5-7 foliate with stipules; flowers showy, solitary or several together on axillary peduncles; calyx 5-cleft, the upper two lobes sometimes united; vexillum large, wings curved, keel nearly as long as the wings; stamens monadelphous below; pod narrow. Sandy soil. Spring to Fall, - - Bradburya (Centrosema, Clitoria), Butterfly-pea

B. Virginiana. Upper calyx-lobe twice as long as the tube.

B. arenicola. Upper calyx-lobe shorter than the tube.

26. Cultivated, hairy, twining vine, leaves 3 -foliate, stipellate; leaflets lobed, rhombic to orbicular; flowers large, purple, in axillary spikes or racemes; standard equal to wings and keel; pod linear, flat, many-seeded. Pueraria thunbergiana (Dolichos Japonicus), Kudzu-vine

27. Corolla yellow.-Flowers in terminal or axillary racemes or clusters; twining, trailing or erect, with 1-3 foliate leaves, stipulate and resinous-dotted; calyx more or less 2-lipped, 5-lobed; vexillum broad, wings narrow, keel incurved at the apex; stamens diadelphous, - - - - - - - - Dolicholus (Rhynchosia)

D. tomentosus. Mostly climbing; all or the upper leaves 3-foliate, terminal leaflet the largest; racemes nearly sessile, few-flowered. Dry soil. Summer.

D. minimus. Prostrate or climbing; leaflets small, roundish or broadly rhombic; racemes filiform, loosely flowered. Pinewoods. Summer.

D. mollissimus. Erect; leaves rather remote, 3-foliate; racemes terminal, elon- 
gated, and a few short ones in the axils of the upper leaves. Pindant. Spring to Fall.

D. Michnuxii. Prostrate, twining; leaflets much dilated, hairy; raiemes pedunc'ed, 1-several flowered; corulla pale-yellow. Dry pine-land. Spring to Fall.

27. Corolla not yellow,

25. Peds terete, torulose; corolla scarlet;-erect, more or less reclining: leaves pinnately 3 -foliate with gland-like stipules; fowers showy, in long terminal and axillary racemes, the former leafybracted, the latter naked; calyx truncate; vexillum narrow. straight, long; wings and keel very small; stamens diadelphous or somewhat monadelphous at the base, party exserted; style slender,

E. herbacea, Cherokee Bean. Herbaceous above the root, armed with prickles; leaflets deltoid to hastate; vexillum folded; pods deeply constricted between the seeds, the latter scarlet. Pine-land. Spring.

E. Laurifolia (Crista-galli) and E. speciosa are shrubby and bushy, and planted under the name of Coral Bush.

28. Pods flattened; corolla purple or white;-decumbent, prostrate or twining herbs, leaves 3 -foliate, rarely 1-9 foliate; stipules deciduous; flowers in axillary raceme-like panicles; calyx 4-toothed; vexillum broad, reflexed; wings oblong with the keel adhering; stamens diadelphous or monadelphous to the middle; style finform; pods sometimes produced from underground apetalous flowers. In dry soil and pine-land,

Galactia, Milk-pea

a. Leaves trifoliate,

a. Leaves pinnate, 7.9 foliate;-stems prostrate and climbing; foliage pubescent or silky or smooth; panicles longer than the leaves; corclla white, tinged with red. Spring and Summer.

G. Elliotti

b. Stems erect or decumbent;-foliage smocth; leaflets narrow; racemes few-flowered; calyx with yellow hairs; corolla small, purple. Summer.

- G. brachypoda

b. Stems prostrate;-foliage hoary-pubescent; leaflets oval, the basal leaves mostly 1-foliate; racemes many-flowered; calyxlobes long-acuminate; corolla rose-purple. Summer. - G. Floridana

b. Stems prostrate and climbing, or twining, - - - c

c. Foliage sparingly pubescent; - the terminal leaflets narrower than the other two; panicles not longer than the leaves; corolla violet-purple with a brownish spot on the vexillum. Summer, - - - - - - - - G. regularis

c. Folnage pubescent or pilose;-panicles longer than the leaves; corcila pink-purple. Summer. - _ _ - G. volubilis (pilosa)

c. Foliage villous and somewhat hoary;-panicles erect, sulitary. much longer than the leaves; flowers approximate near the top of the stout peduncles; corolia red or rose-purple. Sumner.

29. Keel sprraliy twisted, pod more or less flatrened. - . -

G. mollis

- 30

29. Keel incurved, pod nearly cyindrical, somewhat toruiose. - - - 31

30. Leaflets 5 or more, not stipeilate; - vines with twining stems and large rocts; leaves cold-pinnate, stipules small; fluwers in dense 
axillary racemes; calyx somewhat 2-lipped; vexillum very

troad, reflexed; stamens diadelphous, - - - Apios, Ground-nut

A. Apios (tuberosa). Roots tuberous; leaflets 5-7, rarely 3, ovate to lanceolate; racemes of ten in pairs, shorter than the leaves; corolla chocolate-brown. Low ground. Summer and Fall.

30. Leaflets 3 , stipellate;-twining or prostrate herbs; stipules persistent; flowers scattered in racemes at the end of the axillary peduncles; calyx 5-toothed, the upper two more or less united; stamens diadelphous, style bearded, pods straight or falcate,

Phaseolus, Bean-vine, Kidney-bean

P. sinuatus. Trailing; smooth; racemes 6-8 times as long as the leaves; corolla pale-purple. Dry pine-land. Summer.

P. polystachus (perennis). Climbing; pubescent; racemes twice as long as the leaves; corolla purple. Margins of fields. Summe:.

Allied with this genus are:

Muchna utilus, Velvel-bean, a twining vine; and Glycine hispida, Soy-bean, an erect branching annual or a vine. Both in cultivation.

31. Vines with prostrate or twining stems and stipulate 3 -foliate lea ves; -

flowers few, in cluster-like racemes at the end of axillary peduncles; ca!yx slightly 2-lipped, 4 toothed; vexillum auricled at the base; stamens diadelphous, included in the curved keel with the style bent upward; style hairy, appendaged below the stigma,

Vigna, China Bean, Cow-pea

V. repens (luteola). Foliage and pods pubescent, peduncles longer than the leaves, corolla yellow. Thickets along the coast. Summer and Fall.

V. Sinensis. Foliage and pods smooth or nearly so, peduncles usually shorter than the leaves, corolla yellowish tinged with purple. In thickets and cultivated. Summer and Fall.

31. Vines with prostrate or twining stems and even-pinnate (mostly 4) leaflets;-flowers 5-7 in an axillary spike, calyx 2-lipped; vexillum orange with a red spot, the rest of the corolla yellow; stamens monadelphous; style not hairy. Cultivated, Arachis hypogea, Peanut, Goober

\section{Geraniaceae, Geranium Family.}

Herbaceous or shrubby plants, mostly with pubescent or glandular foliage; the leaves alternate or opposite, lobed or divided, stipulate; flowers on axillary peduncles, regular, 5 -parted; stamens distinct with versatile anthers, styles united; ovary superior, prolonged into a beak formed by the styles; fruit a capsule (regma), each of the 5 lobes separating elastically from an axis and curling back on the style.

Sepals 5 ; petals 5 , alternating with 5 glands; stamens 10 , rarely 5 ,

Geranium, Crane's Bill

G. Carolinianum. Stems low, forking; leaves reniform in outline, 5-7 parted, segments 3-lobed, lobes entire or incised; peduncles short, making the flowerclusters dense; sepals awned, petals pink or whitish; fruit hairy, seeds obscurely reticulated. Dry soil. Spring and Summer.

The Geraniums of the garden belong to Pelargonium, Stork's Bill, with no 
glands between the petals; upper sepal spurred, the spur adnate to the pedicel; of the 10 stamens 3 or more are sterile.

In Tropaeolum, cultivated under the names of Indian Cress anid Vashurtium. the spur is free; stamens 8 ; ovary 3-lubed. style 1. stigmas 3; fruit not beaked, supa. rating from the short axis into three achenes; leaves alternate, exstipulate.

\section{Balsaminaceae, Jewel-weed Family.}

Smooth and succulent herbs with simple exstipulate leaves and irregular flowers on axillary peduncles; calyx of 3 sepals, the lower one petaloid, saccate and spurred, all deciduous; corolla of 5 petals, the lateral pair on each side united, deciduous; stamens 5 , each filament with a scale and partially united above; ovary 5-celled, stigma 5-lobed, sessile; fruit a capsule with elastically bursting and coiling valves.

Leaves alternate or opposite; flowers orange, mottled with brown. the saccate sepal conspicuously spotted, tipped with a recurved spur one-half as long as the body. Moist soil. Summer and

Fall. - - Impatiens biflora (fulva), Touch-me-nol, Jewel-weed Cultivated species go by the name of Bulsamine; potplants.

\section{Linaceae, Flax Family.}

Chiefly herbs with alternate or opposite narrow leaves; flowers perfect, regular, solitary or in terminal racemes and panicles or corymbose cymes; sepals, petals and stamens 4-6, the stamens alternate with the petals; ovary $2-5$ celled or falsely 4-10 celled; styles $2-5$; fruit a globose capsule with 1-2 seeds in each cell.

Herbs with alternate or opposite, mostly sessile leaves; sepals, petals and stamens 5 , the stamens partly united, often with small staminodia between; ovary 5-celled with false partitions; styles 5, rarely 2. distinct or united.

Linum, Flax

L. usitatissimum. Stems simple or branching above; leaves alternate, linear; flowers blue. Waste places. Summer.

\section{Oxalidaceae, Wood-Sorrel Family.}

Chiefly herbs with sour juice; leaves basal or cauline, compound, with or without stipules, the leaflets notched at the apex and with a membranous fold in the sinus; flowers solitary or in peduncled cymes, umbel-like or dichotomous; sepals 5, persistent; petals 5 , white, purplish or yellow, deciduous; stamens 10-15, more or less united; ovary superior, 5-celled; styles 5, distinct; fruit a capsule.

Plants caulescent, not succulent; leaves alternate. without stipules, palm. ately 3-foluate. leatlets obcor 13t:; Howers yellow. stamens 10; 
fruit a 5-celled capsule.

Xanthoxalis (Oxalis), Yellow Sour-Grass

X. macrantha. Erect or decumbent, strigillose; sepals copiously ciliate all around; petals golden yellow. Riverbanks. Spring to Fall.

X. stricta. Often decumbent, strigillose; sepals sparingly ciliate; petals pale yellow. Roadsides. Spring to Fall.

X. recurva. Tufted, villous; cymes umbel-like; sepals ciliate all around; petals golden yellow. Dry soil. Spring and Summer.

Cultivated species are Oxalis rosea, rose-colored, and O. versicolor, white bordered with red, yellowish below.

\section{Rutaceae, Rue Family.}

Shrubs or trees often armed with prickles; leaves exstipulate, alternate or opposite, simple or pinnately compound, dotted; flowers mostly regular in cymes, paniculate or corymbose; sepals $3-5$, more or less united at the base, or wanting; petals $3-5$ or more; stamens as many to thrice as many as the petals, or more, inserted on a hypogynous disk, distinct or united below; ovaries $2-5$, distinct or united; styles more or less united; stigma often 3-5 angled; fruit capsular or a samara, drupe or berry.

1. Fruit a dry dehiscent capsule; seed solitary;-leaves alternate, oddpinnate; sepals, petals and stamens 4-5.

Fagara

F. Clava-Herculis (Zanthoxylum Carolinianum), Toothache tree, Sea-ash, Prickly ash, Pepperwood. A prickly shrub or tree, leaflets $7-11$, flowers greenish to white. Dry soil near the coast.

1. Fruit a berry; seeds several in each cavity;-cultivated and naturalized shrubs and trees more or less armed; leaves mostly simple, leathery, often with a winged petiole; flowers regular, axillary; calyx cup-like; petals 5 , rarely $4-8$, white, at least inside, deciduous; stamens 20-60; ovary several-celled, superior; styles united, deciduous; berries with a bitter oily rind,

Citrus

a. Leaves trifoliate, deciduous;-leaflets elliptical, dentate or crenate; flowers before the leaves, white, - - - C. trifoliata (triptera)

a. Leaves unifoliate, evergreen,

b. Petioles wingless and marginless; leaves oblong, seriate or crenate; flowers mostly purplish outside; fruit large, mostly ovate-oblong, with a very thick tender rind and but slightly developed pulp, - - - - - - - C. Medica Citron*

b. Petioles with wings or margins, - - - - - - - - c

c. Wings broad or narrow, - - - - - - - - - d

c. Wings very narrow or mere margins, - - - - - - - - e

d. Leaves elliptical or ovate, acute, obtuse or acuminate; flowers white. (The Otaheita Orange with pinkish flowers is cultivated as a dwarf potplant). - - - C. aurantium, Or ange Var. amara (C. Bigaradia), Sour, Bitter or Seville Orange. Petiole broadly wing-margined;-leaves ovate, pointed; flowers sweet-scented; fruit round, dark orange; pulp sour and bitter. 
Var. Sinensis (dulcis), Common sweet or ange. Petinle nartowly winged; -leaves oblong-ovate, pointed: flowers large: fruit mainly round, orange or yellowish; pulp when ripe sweet or slightly acid.

Cultivated forms according to the time of ripening are: Parson Brown. Ruby, Nanel. Centennial. Homosassa, Majorca. Tardiff or Hari's lase, and Lue Gim Gong: the last named being almost frostproof and bolding on the tree for longer than a year, originated in DeLand.

d. Leaves large, ovate or ovate-oblong. obtuse, often emarginate; petiole broadly winged; flowers white; pulp pale yellow or reddish. sweet or acid.

- C. Decumana

Pomelo, or Grope-fruil, is round:-cultivated forms are: Marsh Seedless, Royal, Ellex. Wollers, and Foster; the last named is a sport from Walters and has pink pulp. Shaddock is pear-shaped;-not cultivated for market.

d. Leaves oval or cllipt?cal. small, crenate or serrate; petiole wingmargined; flowers small, white or pinkish outside; fruit lightyellow, small, spherical, ovate or elliptical; rind thin, bitter; pulp very sour, somewhat bitter. Very tender, - c. limetta, Lime The Tohiti, nearly seedless, and the Rangpur with reddish pulp are the best.

e. Petioles scarcely winged:-foliage dense, leaves small. lanceolate, slightly crenate; flowers small, white, in clusters; fruit compressed or pyriform; rind loose; segments loosely ad-

berest; pulp sweet, - - - C. nobilis, Mandarin, Kidglove Cultivaied forms are: Mondarin, small, light orange; Tangerine dark orange or reddish; Salswma, flattened, orange.

e. Peticies narrowly wing-margined;-branches smooth, angu!ar; leaves linear-lanceolate. slightly serrate; fowers small, scilitary or in clusters; fruit small; rind sweet, pulp sour,

C. Japonica, Kumqual

Cuitivated forms are: Marumi, fruit round; Nasami, fruit oval or oblong.

e. Petioles slightly winged or marginless;-leaves ovate-obiong. crenate or serrate; flowers often reddish outside; fruit yellow. round, ovate or elliptical, mostly mamillate; rind thin, pulp juicy, acid. Lamb and Genou are best known.

C. limonum, Lemon

\section{Meliaceae, Mahogany Family.}

Trees or shrubs with alternate exstipulate leaves, oddpinnate to thrice-pinnate; flowers in axillary panicles; sepals and petals $3-5$, more or less coherent, and the latter sometimes adnate to the stamen tube; stamens 8-10, with filaments united into a tube; ovary $3-5$ celled, superior; styles united; ovules 2-many in each cavity; fruit a berry, capsule or drupe; seeds winged or wingless.

1. Ovules many in a cavity; fruit a capsule as larke as an orange; seuds winged;-flowers greensh yellow. A tall evergreen tree of Soutb Fionda, - - - Swieteaia, Mohigeny, Maderro Redwood

1. Ovules two in a cavity; fruit a drupe as large as a cherry; seeds wingless;- lowers wibite to purple, sepals and perals 5. sometumes 6; 
staminal tube 10 or 12 -lobed, each lobe $2-3$ cleft, anthers 10 or 12; ovary 3-6 celled; drupe with a 1-5 celled stone, and the seeds solitary in each cavity. Spring. - _ - Melia, Pride of India

M. Azedarach, China-berry Tree. A large deciduous ornamental tree with twicepinnate leaves, flowers lilac, berries yellow.

The var. umbraculifera, Umbrella-tree, has a depressed umbrella-like top; another var. semperflorens, Dwarf China-berry, is a shrub blooming at any time of the year.

\section{Polygalaceae, Milkwort Family.}

Herbs or rarely shrubs with entire exstipulate leaves and irregular hypogynous flowers; calyx of 5 sepals, of which the two lateral are petaloid and are called wings; corolla of 5 or 3 petals, of which the lower, often beaked or crested, is called the KEEL; stamens 8,6 or 4 , usually united into a tube, cleft on the back; ovary 2-celled, styles united, stigma curved, dilated or lobed; fruit mostly capsular, 2-celled.

Leaves alternate, opposite, or whorled; flowers in densely crowded spikes or racemes; some species produce racemes of cleistogene flowers at the base; sepals 5 ; petals 3 , rarely 5 ; stamens 8 , rarely 6 , united into a tube or in two equal sets; style curved, stigma 2-4 lobed; capsule flat, 2-celled; seed 1 in each cavity, usually bearing a caruncle,

1. Leaves alternate,

1. Leaves whorled,

2. Flowers purplish,

2. Flowers white or yellow

3. Flowers in slender loose-flowered racemes, -

3. Flowers in slender, loose-flowered racemes, - - - - - - - 4

3. Flowers in dense spike-like racemes, - - - - - - - - 5

4. Keel without beak or crest;-branching at the base, sparingly above; pubescent; flowers pink or violet-purple, becoming greenish; lateral petals much shorter than the naked hooded keel; stamens 8 , monadelphous below the middle; style dilated and bearded above. Pine-woods. Summer and Fall. - - P. grandiflora

4. Keel crested with large branching processes;-branching at the base, simple above; flowers rose-purple to pink; cleistogene flowers present; stamens 8 ; style short, hooded. Dry sandy soil. Summer. - - - - - - - - - - P. polygama

5. Stamens $6 ;-$ not or sparingly branched; leaves scale-like; flowers pink or whitish; wings thrice longer than the other sepals; keel somewhat crested; style short, auricled above. Low pine-land. Spring and Summer.

P. setaces

5. Stamens 8 ;-slender, striate or angled, sparingly branched above; leaves small; flowers pink or purple; wings mucronate; petals united below into a cleft tube; keel crested; style filiform, auricled above. Sandy soil. Summer.

P. incarnata

6. Flowers in dense subglobose racemes, solitary, - - - - - - 7

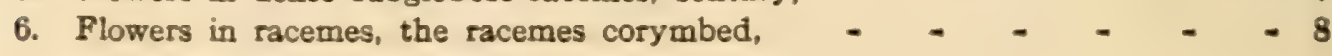


7. Wings acuminate;-low, erect, often tufted; flowers yellow or greenish yeliow; keel crested; stamens usually 6, style slender. Pinebarrens. Throughout the year.

7. Wings cuspudate; -ascending or decumbent; fowers orange-yellow; P. nana keel with a small firmbriate crest; stamens 8; style slender, prolonged into a curved tufted appendage. Low pine-land. Spring and Surnmer.

P. lutea, Wild Bachelor's Bullon

8. Corolla white;-erect. branching above; wings ovate-lanceolate, keel with a minute fimbriate crest; stamens 8 ; style slender. Low pine-barrens. Summer. - _ - _ - - P. Baldwinii

8. Corolla yellow,

9. Wings acuminate;-erect, branching above; wings twice or thrice larger than the other sepals; keel with a small fimbriate crest; stamens \&; sty!e slender, auricled above, prolonged into a curled appendage. Pine-barren swamps. Summer and Fall.

P. ramosa

9. Wings cuspidate;-erect, branching above; wings nearly twice as large as the other sepals: keel with a crest of few small processes; stamens $S_{\text {: }}$ style broader at the middle, prolonged into a curved appendage. Pine-barren ponds. Summer. - - P. cymosa

10. Plowers in slender spike-like racemes, - _ _ - _ - - - 11

10. Plowers in dense, ovoid or cylindric racemes, - _ _ _ _ - 12

11. Stamens erect. filiform; leaves in distant whorls of 4 or 5 , setaceous: flowers greenish, wings oval, keel crested; capsules longer than broad. Dry sand-hills. Spring and Summer. - P. leptostachys

11. Stems short or long, branched; leaves usually in whorls of 4 or 5 . linear; flowers greenish white, wings ovate, keel crested; capsules longer than broad. Dry sandy soil. Spring to Fall. P. verticillata

12. Racemes long-peduncled; wings with a thick excurrent midvein:erect or decumbent, 4-angled; lower leaves in whorls of 4 , lanceniate or linear; flowers rose-purple, keel crested; stamens 8. Bogs. Summer and Fall. - _ - - - - P. brevifolia

12. Racemes sessile or short-peduncled; wings tapering into a long subulate puint;-more or less branched, 4 -angled; leaves in whorls of 4 or 5 , spatulate-linear; flowers rose-purple or greenish; keel crested; stamens 8. Pine-barten swamps. Summer. - P. cruciata

\section{Euphorbiaceae, Spurge Family.}

Monœcious or dioecious herbs, shrubs or trees with acrid, and often milky, sap; leaves simple with or without stipules; flowers various, sometimes enclosed in a cupshaped involucre; calyx inferior or wanting; corolla colored, scale-like or wanting; stamens few or many; ovary free, mostly 3-celled; styles distinct or united; fruit a capsule, mostly 3 -lobed, separating when mature into three 2 -valved, 1-2 seeded carpels, from a persistent axis.

1. Flowers not in an involucre; calyx of several sepals, more or less united. - 2

1. One fertile and several monandrous sterle fowers, without envelopes.

encirsed in a crommon involucre (Euphorbias), - - -

2. Ovary 3-cilled, cells 2-ovuled;-leaves alternate, sometimes resemb- 
ling leaflets of a compound leaf; flowers small, greenish, apetalous, a staminate and a pistillate one together in an axil; sepals 5-6; stamens 3 with filaments partially united; styles 3,2 -cleft; fruit with 2-seeded carpels. Low ground. Summer. - Phylliantus

P. Carolinensis. Smooth slender stem with 2-ranked branches; caly x 6-parted; seeds semi-circular, 3-angled, marked with lines of minute papillae.

P. nivosus (Breynia nivosa), Snow Bush. Cultivated for its foliage, which is green variegated with white and mottled with pink and rose.

2. Ovary 1-or 3-celled, cells 1-ovuled, - - - - - - - - 3

3. Flowers in bracted spikes or racemes, the staminate above the pistillate, - 4

3. Flowers in apetalous cymes or in racemes, the pistillate above the staminate, 9

4. Corolla present in either staminate or pistillate flowers or in both (except in Croton maritimus), - - - - - - - - - 5

4. Corolla wanting,

5. Stamens 6 or more; capsules 3-celled;-stellate-pubescent or scaly, monœcious herbs or shrubs with mostly alternate leaves; flowers in axillary or terminal clusters; staminate flowers with 4-6 coherent sepals and petals, and 5-many distinct stamens; pistillate flowers with 5-10 sepals, usually no petals, and 2-3 styles once to thrice 2 -cleft,

C. argyranthemus. Leaves with silvery scales beneath; sterile flowers 10-15 with 10-12 stamens, fertile ones few with 5-7 parted calyx and slender 4 cleft styles. Dry pine-land. Summer.

C. glandulosus. Herbs with stellate foliage; sterile flowers minute, white with 4-parted calyx and 4 petals; stamens 8 ; fertile flowers with 5-parted calyx and 6-cleft styles. Waste places. Summer.

C. punctatus (maritimus). Tall bushy herb, gray stellate-pubescent all over; sterile and fertile flowers few, both without corolla; calyx 5-cleft; stamens mostly 12 ; stigmas 18-20. Along the coast. Summer and Fall.

Numerous Crotons (Codiæum) are cultivated for their brilliantly variegated leaves.

5. Stamens 5; capsules 1-celled;-silvery-scurfy, monœcious herbs with narrow alternate leaves; sterile flowers with 5 sepals and 5 petals; fertile flowers with $3-5$ sepals, no petals, but 5 petal-like glands opposite the sepals; stigmas 3, each 2-cleft, - - - Crotonopsis

C. linearis. Stems wiry, leaves few; fruit small, scaly. Dry sand. Summer.

6. Stamens 8-16, ovary 3-celled, stigmas fringed;-monœecious herbs with alternate, serrate, stipulate leaves; sterile flowers with 4-parted calyx, in the axil of a minute bract; fertile flowers with 3-5 parted calyx, subtended by a leafy bract. Dry ground. Summer.

Acalypha, Three-seeded Mercury

A. gracileus. Pale green; leaves short-petioled, bracts not longer than the spikes.

A. mosaica (triumphans). Cultivated for the foliage, the leaves having all shades of green, yellow and red, with curious markings.

A. hispida (Sanderi). Chenille-plant. Cultivated for its long red spikes.

A. marginata. Tall plant, the green leaves margined with red and pink. Cult.

6. Stamens 1-5, - - - - - - - - - - - 7

7. Pistillate flowers and capsules pedicelled;-monœcious herbs with alternate leaves; sterile flowers with $3-5$ parted calyx, and fertile flowers with 3-8 parted calyx; ovary 3-celled, styles 3 often united to above the middle. Sandy soil. Spring to Fall. - Tragia 
T. ureas (innocua). Downy, low herb with nearly sessile leaves and slender racemes surpassing them in length; sterile flowers with 4 sepals and 2 stamens.

7. Pistillate flowers and capsules sessile.

8. Roceptacle with 3 homs;-smooth monocious plants with milky juice, and alternate leaves often with 2 glands at the base; sterile flowers several together, with 2-3 touthed calyx and $2-3$ exserte 1 stamens; fertile thowers solitary or few, with 3-lobed calyx an 1 stout style. - - - Stillingia, Queer's Deligh, Queer-r oot

S. sylvatica. Stout herb, umbellately branched above; leaves lanceolate to obovate, crenulate; spikes yellowish, longer than the leaves. Dry suit Spring to Fall.

S. aquatica. Shrub with umbel-like top; leaves linear, finely serrate, the uppor ones yellowish; spikes not longer than the leaves. In and about pine-barren ponds. Spring to $\mathrm{Pall}$.

8. Receptacle with a central column;-dioecious or monoecious shrubs or trees with alternate or opposite entire leaves; flowers in spikes or racemes; calyx 2-3 lobed, corolla wanting; stamens 2-3 with distinct filaments; styles $2-3$ slightly united below; ovary $2-3$ celled, ovuies solitary in each cell; fruit a capsule. - _ Sapium

S. sebiferum, Tallow-tree. A large tree with rhombic leaves, deep green in summer, brilliantly colored in autumn; flower-spikes terminal. Spring. Cult.

9. Leaves peltate;-tall, glabrous, monœecious herbs with large, petioled, paimately-lobed leaves; sterile flowers with a $3-5$ parted calyx and numerous stamens; fertile tlowers with a caducous calyx, 3-celied ovary, and 3 red styles united below and 2 -cleft; fruit usually spiny, consisting of three 1-celled, 1-seeded, 2valved carpels,

Ricinus, Castor-Bean

R. communis, Palma Christi. Stem branched, leaves large 6-11 lobed; racemes in the forks of the stem opposite the leaves; seeds shining, mottled. Cultivated and escaped. Summer and Fall.

9. Leaves not peltate,

10. Plants wild; - stinging bristly herbs and shrubs, with alternate. petioled, lobed leaves; flowers in cymes, tha sterile jnes with a corolla-like 5-lobed calyx, stamens $10-30$ in series, flaments united below; fertile flowers in the lower forks of the cymes, ovary 3 celled, styles united below; fruit separating into 2 -valved carpels,

C. stimulosus (Jatropha stimulosa), Spurge Nelle. Bright-green foirage, 3-5 lobed; calyx of sterile flowers salver-shaped, white, sometimes pinkist. Dry sandy soil. Spring to Fall.

10. Plants cultivated,

11. Flowers in forked cymes, corolla present; - herbs with angled or lobed leaves; sepals and small petals 5 ; stamens 10; ovary $2-3$ celled. Jatropha

J. multifida. Leaves 9-11 lobed; flowers scarlet.

11. Fluwers in racemes or panicies; corolla absent; -herbs or shrubs with alternate, entire or 3-7 libed leaves; Howers with 5-tuothed caijr; the sterie with 10 stamens in twi series, the fertile with 3 styies singhiy united; capsuie 3-celied, with seclis sjitiary in cach cell, 
M. utilissima, Bitter Cassava. Anthers short; capsule wing-angled;-roots contain poisonous juice which is pressed out or rendered harmless by heating; tapioca is made from the rootstarch.

M. palmata, Sweet Cassava. Anthers elongated; capsule only angular above. not winged;-roots more reddish colored and not poisonous.

12. Glands of the involucre with petal-like appendages, which may be much reduced;--stems branched at the base; leaves all opposite, with delicate entire or fringed stipules; involucres solitary in the axils or in axillary cymes; glands 4 , one sinus of each involucre being without a gland, - - - - Chamaesyce (Euphorbia)

C. (E.) maculata. Dark green, pubescent, with prostrate often dark-red branches and oblong leaves, usually blotched; involucres solitary in the axils, the glands with narrow, white or red appendages. Waste places. Spring to Fall.

12. Glands of the involucres without petal-like appendages, - - - 13

13. Stem simple or branched, topped by an umbel; leaves below the umbel alternate or scattered; no stipules; bracts of the umbel different from the stem-leaves; involucres axillary, in cymes; glands 4 , and a thin often ciliate lobe instead of the fifth,

Tithymalus (Euphorbia)

T. inundatus (E. inundata). Stem topped by a 2-3 rayed umbel and simple or branched below it; leaves alternate; glands reniform. In pine-land swamps. Early Summer.

13. Stem not topped by an umbel; leaves alternate below, opposite above; stipules gland-like;-herbs or shrubs often with colored foliage, leaves all similar; involucres solitary or in cymes; glands 1 , rarely 3 or 4 , the missing ones represented by narrow lobes,

Poinsettia (Euphorbia)

P. heterophylla, Painted leaf, Hypocrit. Stems erect with spreading branches; leaves linear, ovate or obovate; leaves and bracts blotched with red. Sandy soil. Spring to Fall.

P. (E.) pulcherrima. A tall tropical plant with large scarlet bracts subtending the flowers. Cultivated. Winter and Spring.

Other Euphorbias are cultivated in pots, as the twining E. splendens, Crown of thorns; the stem covered with stout spines; leaves few, bright green; flowers in forked cymes, closely subtended by two bright red, ovate bracts.

Pedilanthus tithymaloides, Bird-cactus. Baby-foot, a shrubby plant with zigzag fleshy stem and branches; the red involucres, oblique and strongly 2lipped, in contracted cymes; stamens and style exserted.

\section{Callitrichaceae, Water-Starwort Family.}

Small herbs, mostly aquatic, with opposite, entire leaves; flowers polygamous, axillary, solitary; perianth wanting; 1 stamen, 2 styles, ovary 4 -celled with ovules solitary in each cell; fruit a leathery capsule.

C. peploides. Stems branching, forming wide mats on moist earth. Spring. 103. Empetraceae, Crowberry Family.

Evergeeen shrubby plants with erect or prostrate stems; leaves alternate or whorled, narrow, revolute; flowers 
dicecious, axillary, small; calyx of 2-3 scale-like sepals; corolla of 2-3 petals, or wanting; stamens $2-4$; ovary 2 -several celled, with ovules solitary in each cell; styles united, stigmas tufted or cleft; fruit a fleshy drupe with 2-many nutlets.

Erect shrubs with whorled branches; leaves whorled; flowers in whorls of 2-3. reddish; calyx of 2 sepals subtended by 2 bracts; petals 2: stamens 2; ovary 2-celled, stigma many-cleft; nutlets 2. - Ceratiola

C. ericoides. Aromatic shrub with pubescent branches; stamens exserted; drupe yellowish. Dry pine-land. Spring.

\section{Spondiaceae (Anacardiaceae), Sumac Family.}

Shrubs, vines or trees with a milky, resinous, often caustic, sap; leaves exstipulate, alternate, simple or pinnately compound; flowers in spikes, racemes or panicles; sepals and petals $3-6$; stamens $3-6$, or 10 , alternate with the petals, and inserted with them on the base of the calyx or on a hypogynous disk; ovary solitary, free; styles united, sometimes distinct; fruit a drupe or berry, seed solitary.

1. Leaves 3-foliate, drupe glabrous, stone ribbed;-flowers polygamous or dioecious, in axillary panicles; poisonous, resinous sap.

Toricodendron

T. ndicans, Poison-iry. A vine, climbing by rootlets; leaflets 3 , membranous, ovate or ovate-lanceolate, coarsely toothed or rarely lobed, sparingly pubescent. acuminate at the apex, rounded or acute at the base; panicles loosely flowered, flowers greenish; sepals. petals and stamens 5; drupes subglobuse, whitish. Thickets. Spring and Summer.

I. toxicodendron, Poison-oak. Low shrub, spreading by underground stems; foilage and inforescence tomentose; leaflets 3 . leathery, ovate, crenate or Jobed; panicles densely flowered; flowers greenish-white; sepals, petals and stamens 5; drupes depressed-globose, greenish-yellow. Pine-land. Spring.

1. Leaves 3-several foliate, drupe putescent, stone smooth:-flowers polygamous or diaecious, in terminal panicles; plants not poisonous.

R. copallins, Dwarf Sumac. A shrub with sticky milky sap; foliage smon:h or pubescent; leafets lanceolate or oblong, 9-25. acute at the apex; the racins winged; panicles broad. densely flowered; flowers greenish; stamens in ster:ie fowers exserted; drupes bright red. Open wouds. Summer.

R. obtusifolia. A shrub wib pubescent foliage; leaflets ovate to oblong. sounced at the apex. 17-21; the rachis narrowly winged; panicles bruad, leafy, pubescent; flowers greenish w bite. Swampy pine-land. Summer.

105. Aquifoliaceae (nicaceae), Holly Family.

Mostly evergreen shrubs or trees with alternate, exstipulate leaves, sometimes spiny; flowers small, perfect or polygamous; calyx of $4-6$ persistent sepals; corolla $4-6$ 
cleft or parted, hypogynous, white or greenish, deciduous; stamens 4-6, inserted at the base of the corolla and alternate with the petals; ovary 2-6 celled, with 1-2 ovules in each cell; fruit a drupe with 4-8 nutlets.

Flowers sometimes diœcious, the sterile in axillary clusters, the fertile solitary; corolla rotate,

1. Leaves deciduous,

1. Leaves evergreen,

2. Leaves thickish, spatulate, oblanceolate or elliptic, crenate-serrate, glabrous above, usually pubescent an 1 paler beneath; flowers in axillary clusters; corolla white; drupe orange or scarlet. River-swamps. Spring. - - - I. decidua, Possum-haw, Bear-berry

2. Leaves rather thin, broadly oval, ovate, sometimes elliptic, serrate above the middle, glabrous on both sides; sterile flowers clustered, fertile ones solitary; corolla white; drupe red. Sandy margins of swamps. Spring. - - - - I. Caroliniana (ambigua)

3. Drupe black, - - - - - - - - - - - 4

3. Drupe red, - - - - - - - - - - - - 5

4. Velvety-pubescent; leaves obovate to oval, crenately $\mathbf{2 - 4}$ toothed near the apex; dark green and lustrous above, paler and dull beneath; sterile peduncles many-flowered, the fertile 1-flowered; flowers white. Sandy soil towards the coast. Early Summer.

I. glabra, Ink-berry

4. Glabrous, or nearly so; leaves obovate to oval, entire with scattered spiny teeth; dark green and lustrous above, paler beneath; peduncles 1-flowered, the sterile ones mostly clustered, the fertile solitary; flowers white. Swamps. Late Spring.

I. lucida (coriacea)

5. Leaves entire or with few appressed teeth near the apex,

5. Leaves crenate-serrate;-sometimes forming thickets; flowers in axillary clusters; corolla white, the lobes in the fertile flowers longer, those in the sterile flowers shorter than the stamens. Banks of lakes and river. Spring.

I. vomitoria (I. Cassine, Walt.), Cassine, Yaupon

5. Leaves parchment-like, oval to obovate, spine-tipped at the apex and spiny-toothed or entire;-bark pale; stamens longer than corolla in the sterile flowers, shorter than corolla in the fertile flowers; drupes red, rarely yellow. Woods, and planted. Spring.

I. opaca, Holly, White Holly

6. Leaves oblanceolate or oblong;-petioles usually pubescent; flowers in umbel-like clusters; corolla white, the lobes mostly longer than the stamens; drupes sometimes yellowish-red, solitary or 3 in a cluster on stout pubescent pedicels. Swamps near the coast, and planted. Spring. I. Cassine, L. (I. Dahoon), Dahoon, Yaupon

6. Leaves linear, very rigid;- - petioles short;-- flowers solitary or few in the axils; corolla white, the lobes longer than the stamens. In wet pine-land. Spring.

I. myrtifolia 
106. Aesculaceae (Hippocastanaceae), Buck-eye Family.

Shrubs or trees with opposite, exstipulate, palmatelycompound leaves; flowers in terminal racemes or panicles, polygamous, irregular and unsymmetrical; calyx 5-lobed, with an annular, hypogynous disk; petals 4-5 unequal; stamens $5-8$; ovary 3 -celled, with 2 ovules in each cell; fruit a coriaceous capsule, loculicidally 3 -valved; seed mostly solitary with a leathery testa.

Aesculus Pavia, Red Buck-eye. Shrub with smooth bark; leaflets 5-7, the leaflets oblanceolate, short-acuminate, finely serrate; flowers in a panicle, red; clates of the upper petals villous and as long as the blades, those of the lateral petals winged. several times longer than the blades; stamens slightly exserted; capsule unarmed. Rich soil. Late Spring.

\section{Aceraceae, Maple Family.}

Trees or shrubs with opposite, exstipulate, palmatelylobed leaves; flowers regular, mostly polygamous or diœecious; calyx 4-9 lobed, often colored; petals as many as the calyx-lobes, or none; stamens as many as the sepals, often 8; ovary free, 2-celled, with 2 ovules in each cell; styles united, stigma 2-cleft; fruit a double, 2-seeded samara.

1. Leaves simple, palmately lobed; flowers polygamous, clustered or racemose;-calyx $\mathbf{4 - 5}$, rarely 6-9 lobed; petals 5-8, or none, Acer, Maple

A. rubrum, Red Maple. A tree with pale bark; leaves shallowly 3-5 lobed; lowers appearing before the leaves, in dense, red or yellowish clusters; samaras drooping, red, with long pedicels. Low ground and planted. Early Spring.

A. Floridanum. A tree with white bark; leaves with 3-5 obtuse few-toothed lobes; flowers appearing with the leaves, umbellate; calyx campanuiate; fruit greea. River-swamps. Spring.

1. Leaves pinnately-compound; flowers dioecious, the sterile ones in drooping clusters, the fertile in drooping racemes;-caly' $\mathrm{m}$ minute, corolla wanting, - _ _ - _ - Rulac, Box-elder

R. Negundo (Negundo aceroides). Tree with light green foliage, leaves 3-9 fuliate; flowers appearing before the leaves; samaras drooping. light green. Riverbanks. Spring.

108. Sapindaceae, Soapberry Family.

Trees, shrubs or herbs, erect or climbing; leaves opposite or alternate, usually stipulate, simple or pinnately compound; flowers in racemes, panicles or corymbs; calyx 4-5 lobed, with an entire or lobed hypo- or perigynous disk; petals $4-5$, or none; stamens 5 or $8-15$; ovary $2-4$ celled 
with partially united styles; ovules 1 -several; fruit a capsule.

1. Shrubs or trees with alternate, pinnately compound leaves; flowers polygamous, in axillary or terminal racemes or panicles; calyx 4-5 parted; petals 4-5; stamens $8-10$; ovary $2-4$ celled, styles united to distinct, stigmas $2-4$; ovules 1 in each cell; fruit berrylike,

Sapindus, Soapberry

S. marginatus. Small tree; leaflets $7-13$, lanceolate, acuminate; corolla white, tinged with red; stamens longer than the petals, with filaments pubescent at the top; mature carpels 1-2, drupe-like with orange pulp and brown seeds. Low sandy soil. Spring; fruit in Fall.

S. saponaria. Small tree; leaflets 4-7, oblong to obovate; sepals and petals ciliate; stamens about as long as the petals, with filaments pubescent to above the middle; carpels 1-3 with orange-brown pulp and black seeds. Cultivated.-S. makrossi is more hardy.

1. Shrubs or herbs, climbing by tendrils with ternate to decompound leaves; flowers polygamo-diœcious in axillary racemes or corymbs; sepals and petals 4, unequal in pairs; stamens 8; ovary 3-celled, styles 3, united at the base; one ovule in each cell, - Cardiospermum

C. Halicacabum. A climbing or trailing herb; leaflets 3, incised or parted; flowerclusters small, peduncles with tendrils; capsules longer than broad; seeds brown or black with a white aril. Thickets. Summer and Fall.

\section{Frangulaceae (Rhamnaceae), Buckthorn Family.}

Trees or shrubs, some of them armed, with mostly alternate, simple leaves, and small, often deciduous stipules; flowers small, greenish or whitish, perigynous; sepals 4-5, united below, the disk lining or filling the tube; petals, when present, $4-5$; stamens $4-5$, opposite to the petals and inserted with them on the edge of the disk; ovary 2-3 celled, partially above the disk; styles and stigmas more or less united; ovules 1 , rarely 2 , in each cell; fruit a capsule or drupe.

1. Shrubs, often spiny, with minutely stipulate 3-veined leaves, and small flowers in terminal panicles, cymes or umbels; calyx white, 5 cleft; petals 5, long-clawed, hooded, protruding between the sepals; stamens 5 , exserted; ovary 3-celled; style short, stigmas 3; drupe berry-like, 3-lobed, - _ _ - _ - Ceanothus

C. microphyllus. A slender, yellowish, evergreen shrub, glabrous, much branched, with small leaves; panicles loosely flowered. Pine-barrens. Spring.

C. Americanus, Jersey-tea, Red-root. Deciduous shrub, pubescent, with ovate, serrate leaves; panicles densely flowered, peduncles elongated. Dry woods. Summer.

1. Shrubs, spinescent, with nearly opposite leaves; small flowers in axillary clusters or terminal in panicled spikes; sepals 5 ; petals 5 , clawed, hooded; stamens 5; ovary 3 -celled; style 3 -grooved with 3 stigmas; drupe berry-like separating into 3 nutlets, 
leaves on short petioles; spikes slender; drupe dark purple. Sandy soil along the coast. Spring.

110. Vitaceae, Grape Family.

Climbing shrubs with opposite and alternate leaves, and small greenish flowers in an axillary inflorescence; calyx truncate or obsolete, with or without disk; petals 4-5, perigynous or hypogynous, often caducous; stamens 4-5, opposite the petals; ovary 2 -celled, or 3-6 celled; style short or none, stigma capitate or peltate; ovules $1-2$ in each cell; fruit a berry.

1. Calyx-disk present; leaves simple or compound. - _ _ - _ - 2

1. Calyz-disk wanting; leaves digitately 5-7 foliate:-climbing vine with forking tendrils and al rnate leaves; flowers in corymbs; petals and stamens 5 , ovary 2-celled, the cells 2-ovuled; berries inedible, - - - Parthenocissus, Virginia Creeper. American Ioy

P. (Ampelopsis) quinquefolia. Tendrils adhering by disks; leaflets 5 ; berries deep blue, sometimes quite pulpy. Low grounds and planted. Early Summer.

2. Petals cohering, caducous; bark shreddy, tendrils forking;-vines with alternate leaves, simple or palmately lobed, angled, or coarsely toothed; flowers with minute calyx, caducous corolla. and exserted stamens which altemate with the lobes or glands of the calyx-disk; berries juicy. mostly edible, - - - Vitis, Grape

V. cordifolia, Frost-Grape, Chicken-grope. Leaves ovate in outline, or 3-lobed near the apex, coarsely toothed, cordate at the base, long-petioled; panicles drooping; berries black, acid. Thickets. Early Summer.

V. vulpina, Muscadine. Leaves glossy, 3-lobed and irregularly toothed, teeth and lobes acuminate, cordate or truncate at the base; stipules commonly ample; flowers in panicles; fruit dark purple with copious bloom and sour pulp. Riverbanks. Early Summer.-A form with small leaves, and very sour small berries is called Mustang-grape.

2. Petals distinct, spreading, - _ - _ _ _ - _ _ - 3

3. Climbing vines with few tendrils and alternate, lobed or pinnately compound leaves; flowers in flat cymes; petals and stamens mostly 5, the latter exserted; berries inedible. - - - Ampelopsis

A. arborea (bipinnata), Pepper-vine. Few forking tendrils; leaves bipinnate, cymes long-peduncled but shorter than the leaves; disk surpassed by' the ovary; berries dark purple. Marging of swamps. Summer.

3. Climbing vines with strong tendrils; leaves alternate, 3-foliate or

3-parted; flowers in small cymes; petals and stamens mostly 4; berries inedible.

C. acida. Shoesiring sine. Tentrils $3 \mathrm{~m}$. and more long. Cult.

The principal cultivated Florida grapes are: the James, with a very large, mearly black berry; the Meisch, with a medium sized purple berry, and the SCupper. nons, with a greenish-amber large berry; fruit August and September.

\section{Malvaceae, Mallow Family.}

Herbs and shrubs with palmately-veined, alternate, stipulate leaves, and regular, perfect flowers; sepals 5, 
united at the base, often subtended by an involucel; petals 5 , hypogynous, distinct or united; stamens many, monadelphous, with reniform 1-celled anthers; pistils several, distinct or united; fruit a several-celled capsule, or a collection of 1-seeded indehiscent carpels; seeds 1-many.

1. Calyx without involucel,

1. Calyx with an involucel,

2. Cells of the ovary $3-9$ ovuled;-leaves softly pubescent, usually cordate at the base; flowers axillary, petals distinct; carpels 5-30, 1-celled; seeds 1-6 in each carpel, - - - Abutilon, Indian Mallow

A. Abutilon (Avicennae), Velvet-leaf. Leafblades 1-3 dm. in diameter, and petioles commonly as long as the blades; petals yellow. Waste places. Summer and Fall.

2. Cells of the ovary 1-ovuled;-leaves pubescent; flowers solitary or clustered in the axils, sometimes in a terminal inflorescence; carpels 5-many, 1-celled; mature carpels around an axis. Summer and Fall.

Sida

S. thombifolia. Minutely downy or smooth annual, branching; leaves oblanceolate to obovate, pubescent beneath; calyx-tube 5-10 ribbed; petals pale yellow, sometimes with a red blotch at the base; carpels 10-12. Waste places.

S. spinosa. Minutely pubescent annual, simple or much branched; leaves lanceolate to ovate, the petioles of the larger ones with a spine at the base; petals pale yellow; carpels about 5 . Roadside.

S. Elliotti. Roughish pubescent to smooth perennial, branched at the base; leaves linear; calyx smooth; petals yellow; carpels 8-12. Sandy soil,

S. rubromarginata. Minutely downy or smooth perennial; much branched, purple; leaves narrowly obovate to lanceolate, light green with purple margins; calyx angled; petals light orange; carpels 8-10. Sandy soil.

3. Ovary 5-celled,

3. Ovary many-celled,

4. Cells 1-ovuled,

4. Cells 2-many ovuled,

5. Stigmas 10 , twice the number of carpels, - - - - - - -6

5. Stigmas 5, as many as there are carpels;-leaves angularly lobed; involucels of 7-10 bractlets; flowers pink; capsule 5-angled. In marshes near the coast. Spring to Fall. - - -

K. Virginica. Leaves pubescent with stellate hairs, or scabrous.

K. althaeifolia. Leaves velvety-pubescent.

6. Carpels with barbed awns all over; - shrubby, with pubescent, angled or lobed leaves; involucels of 5-7 more or less united bractlets; corolla purplish; carpels arranged around an axis forming a bur-like fruit, - - - - - - - - - - Urena

U. lobata, Spanish cockleburr. Leaves shallowly 3-5 lobed, whitish and prominently veined beneath. Waste places. Spring to Fall.

6. Carpels unarmed;-shrubs with alternate, petioled, entire leaves; involucel of 7-12 narrow bractlets; flowers axillary; sepals 5 ; petals 5 , each with a lateral auricle; ovary 5-celled; styles 2-parted; ovules solitary; fruit berry-like, 
M. Drummondii. Stem erect: leaves cordate. 3-inbed, with petioles shorter than the blades; flowers vermilion; berry red. Cultivated.

7. Involucel of 3 distinct bractlets; carpels 2-seeded;-herbs, prostrate. with alternate, faimately-loted leaves; fowers axillary, inconspicuous; sepals and petals 5 ; carpels iransversely 2-celled, stigmas 15-20,

M. Caroliniana (multifida). Stems tiranched at the base; leaves cordate, 3-5 cleft; petioles shurter than the thlades; flowers red. Waste places. Summer.

7. Invoiucel of 6-9 bractlets; carpels 1-seeded, arranged around an axis, Althnea

A. rosea, Hollyhock. Leaves cordate, 5-7 angled. Cultivated.

8. Invelucel of 3 conspicuous bracts; styles united;-leaves palmately loved or entire; calyx cup-like; petals white or yellowish, turning pink or magenta; ovules numerous in each cell. Cultivated.

Gossypium, Collon

G. Barbadense, Sea-Island Colton. Lobes of the leaves 3-5, mostly longer than the body; seeds smooth, completely separable from the cotton.

G. herbaceum, Lipland or Common Collon. Lobes of the leaves 3-5, mostly shorter than the body; seeds with a close persistent coat.

G. religiosum. Shrubby; leaves with 3 lobes shorter than the body of the leaves; seeds with a close persistent coat, tawny.

8. Involucel of several, rarely $3-5$ bractlets; styles spreading;-herbs, shrubs or trees, - - - - - - Hibiscus, Rose-mallow

a. Caly equally 5 -cleft or toothed, persistent, - _ _ - - b

a. Calyx-tube split on one side, deciduous;-leaves 5-lobed; involucel about 5-bracted, caducous. Cultivated. H. esculentus, Okra, Gumbo

b. Shrubs or small trees;-leaves 3 -lobed; cult. in red, white, pink and rose varieties, where it is not too warm.

H. Syriacus, Shrubby Althaea, Rose of Sharon

b. Herbs,

c. Bractlets 10-12, bristly, forked at the end; leaves hispid;-leaves 3-5 lobed; corolla yellow or cream-colored with a purple blotch. Near swamps. Summer. - - - - H. aculeatus

c. Bractlets entire,

d. Foliage velvety-tomentose;-leaves conspicuously 3-lobed; corolla pale pink with reddish blotch. Marshes near the coast. Summer and Fall. - - _ - _ - = H. grandiflorus

d. Foliage glabrous;-leaves 5-parted with narrow segments; cor-

cila deep red. Marshes near the coast. Summer. - H. coccineus

Single and double varieties of $\mathbf{H}$. rosa-sineasis, shrubby, in pink, salmon, yellow, scarlet and carmine are cultivated.

\section{Sterculiaceae, Cola-nut Family.}

Shrubs and trees with alternate simple or compound leaves; flowers perfect; sepals 5 ; petals 5 or wanting; stamens as many as the sepals or more, sometimes with staminodia, anthers 2-3 celled; ovary of 5 more or less united carpels, or fewer; fruit a capsule or follicle.

Shrubs with large cordate tomentose leaves on long petioles, palmatelyveiaed, border angular, apex somewhat acuminate; pink flowers 
in a large globose umbel on a long peduncle, with an involucre of 10 bracts; involucels of 2-3 bractlets caducous; sepals 5 united below; petals 5 , partly overlapping but not coherent; stamens 15, of which 5 are staminodia, monadelphous; anthers 2-celled; ovary superior, 5 -celled, each cell with 2 ovules; one style with 5 stigmas. Cultivated. Winter. - - - Dombeya Wallichii

D. spectabilis, with straw-colored and pink flowers, and others with white flowers.

113. Hypericaceae, St. John's Wort Family.

Herbs and shrubs with exstipulate, opposite, entire, dotted leaves, and hypogynous flowers in cymes; sepals and petals 4-5; stamens mostly numerous and in 3-5 sets; styles 2-5, often united; capsules 1-celled with parietal placentae, or 2-7 celled with axial placentae; seeds very numerous, small.

1. Sepals 4 , and mostly petals $4, \quad-\quad-\quad-\quad-\quad-\quad-\quad-2$

1. Sepals and petals 5 ,

2. Sepals in pairs, unequal in size or shape, or both; capsule enclosed by outer pair;-shrubs with 2-edged branches; flowers yellow, terminal; ovary 1 -celled, styles $2-4$, distinct or united.

Ascyrum, St. Peter's-wort

A. stans. Leaves clasping; outer sepals longer than the inner, and broader than the leaves; styles 3-4. Moist sandy soil. Summer and Fall.

A. tetrapetalum (amplexicaule). Leaves clasping; outer sepals as long as the inner, and narrower than the leaves; styles 3-4. Moist sandy soil. Spring to Fall.

A. hypericoides, St. Andrew's Cross. Leaves crowded, linear; outer pair of sepals obovate to oblong, inner pair petaloid; styles 2 . Sandy soil. Summer and Fall.

A. pumilum. Leaves sessile; outer pair of sepals ovate or suborbicular, inner pair nearly obsolete; styles 2 united. Dry sandy soil. Spring.

2. Sepals in pairs, slightly unequal in size and shape; capsule longer than the sepals;-shrubby; flowers yellow, terminal, solitary or clustered; petals unequal; ovary 1-celled; styles 3, - _ Crookea

C. microsepala (Ascyrum microsepalum). Branches decumbent or ascending; leaves sessile. Sandy soil. Spring.

3. Petals pink, sometimes tinged with green or purple;-glabrous marsh-herbs; leaves thickish with veins curving along the margins; flowers few, in cymes; stamens mostly 9 , in sets of 3 , with orange glands between the sets; ovary 3 -celled; styles 3 , distinct; capsule longer than the sepals,

Triadenum (Elodea), Marsh St. John's-wort

T. Virginicum. Leaves sessile, sometimes clasping, broadest below the middle. Summer.

T. petiolatum. Leaves petioled, narrow at the base. Summer.

3. Petals yellow, - _ - _ - - - - -,+4

4. Leaves reduced to scales; - somewhat fleshy herbs with the flowers scattered along the branches; stamens 5-20; ovary 1-celled; styles 3 , distinct. In sandy soil, 
S. gentianoides (Hypericum Sarothra), Pine Tassle. Orange-grass. Branches wire-like; flowers sessile, sepals shorter than the capsules; stamens 5-10. Spring to Fall.

S. (Hypericum) Drummondii. Simple or branched, wing-angled; flowers pedicelled; sepals about as long as the capsules; stamens 10-20. Summer.

4. Leaves flat;-shrubs with leaves sessile or clasping; flowers with numerous stamens, distinct or in $3-8$ sets, without glands; ovary 1-celled; styles 3-5, - _ - _ - Hypericum, St. Johr's-wort

a. Stamens 5-12, usually in 3 sets; leaves ovate to oblong; -stem 4-angled, sepals acute. Low places. Summer. , , H. mutilum

a. Stamens $15-40$, distinct or in sets; styles 3 , rarely 4 , - _ - - b

b. Capsules 1-celled; styles distinct; sepals obtuse;-somewhat herbaceous stem, sparingly branched, twigs 2-winged; leaves linear-oblong to oblong, sessile, few; flowers yellow in dichto. mous cymes, forming open corymbs, - - - - H. opacum

b. Capsules incompletely 3-celled; sepals linear, small, not foliaceous, - c

b. Capsules incompletely 3-4 celled; sepals foliaceous;-shrubby; leaves leathery, clasping; corolla golden-yellow, stamens about 120. Pine-land. Summer. - - - - - H. myrtifolium

c. Shrubby, with sharply angled branches; leaves clustered in the axils of larger ones, linear; flowers yellow in loose panicles. Pineland. Spring and Summer. - - - - - H. fasciculatum

c. Shrubby; branches and leaves as in preceding; towers yellow in terminal corymbose cymes. Pine-land. Spring and Summer.

H. aspalathoides (var. of preceding?)

\section{Theaceae (Camelliaceae), Camellia Family.}

Shrubs and trees with alternate, simple, pinnatelyveined leaves, without stipules; flowers regular, hypogynous; sepals and petals 5 , rarely $4-7$ or more; stamens numerous, more or less coherent at the base into 1,3 or 5 sets, opposite the petals; ovary 2-5 celled, with 2-many ovules in each cell; styles $2-5$, distinct or united; capsule 2-5 celled, seeds few.

1. Calyx of many imbricated sepals; stamens united at the base, some of the interior distinct; styles united, stigmas 3-5, - - Camellia

C. Japonica, Camellia. Flowers white or colored, solitary, terminal; stamens about 50, mostly transformed into petals. Cultivated.

C. Thea, Tea-plant. Leaves 2-3 times longer than broad; Howers axillary. white. Cultivated.

1. Calyx simple, sepals 5, unequal; ovules 4-8. Evergreen; flowers white, lons-peduncled; petals 5 , united at the base; stamens numerous on 5 disk-like lobes, confluent at the base; ovary $3-5$ celied; ovules 4 in each cell; capsule pointed, seeds 4 or 2 in eact cavity, each with a membranous wing.

Gordonia

G. Lasianthus, Loblolly-Bay. Swamps and bammocks. Summer. 


\section{Turneraceae, Turnera Family.}

Herbs or shrubs with alternate, exstipulate leaves and solitary, axillary flowers; calyx 5-lobed; petals 5, inserted on the calyx; stamens 5 , inserted below the petals; ovary free, 3 -carpelled, 1-celled; styles 3 ; ovules numerous in 2 rows on the 3 parietal placentae; capsule 1 -celled, 3-valved.

Herbs simple or sparingly branched, with yellow flowers; stigmas 3, 2-

cleft, brush-like. In pine-land. Spring and Summer. - - Piriqueta

P. viridis. Glabrous; leaves linear.

P. Caroliniana (fulva). Hirsute with fulvous hairs, and stellate-tomentose.

116. Cistaceae, Rock-rose Family.

Herbs, woody at the base, or low shrubs, with simple leaves and regular flowers; sepals 5 , of which the 2 outer ones are smaller or wanting; petals 5,3 , or none; stamens few or many, hypogynous; ovary 1-several celled; style single, stigma entire or 3-lobed; capsule 3-5 valved, few or many seeded.

1. Flowers with 5 petals, or apetalous;-leaves with flat or revolute blades; flowers of the first or of both kinds; petals fugacious, yellow; styles short or obsolete. Spring and Summer.

Helianthemum, Frost-weed, Rock-rose

H. Carolinianum. Hirsute; leaves mostly at the base, obovate, ciliate; flowers few, all alike. Dry sandy soil.

H. corymbosum. Tomentose; leaves obovate to oblong, pale beneath; flowers in a terminal fastigiate cyme; those with petals have 25-30 stamens and 20 ovules; those without petals have 3-6 stamens and 9 ovules; calyx of both pubescent. Dry sand towards the coast.

1. Flowers with 3 petals, persistent;-leaves numerous; flowers small, greenish or purplish; stamens $3-12$; stigmas 3 ; capsule $3-1$ celled, about 6-seeded. Summer. - _ - - _ - - Lechea

L. minor. More or less pubescent; stem-leaves oval or oblong, ciliate; flowers red-purple; outer sepals longer than the inner. Dry sand.

L. villosa (major). Villous-pubescent; stem-leaves oblong-elliptic; flowers greenpurple; outer sepals about as long as the inner. Dry sand.

117. Violaceae, Violet Family.

Herbs or shrubs with simple, alternate or basal, stipulate leaves, and perfect, irregular flowers, solitary or clustered; calyx of 5 sepals; hypogynous corolla of 5 petals; stamens syngenesious or connivent; style 1, ovary 1-celled; fruit a loculicidal capsule, 3-valved and many seeded.

Acaulescent or caulescent herbs with solitary, nodding flowers on axillary scapes or peduncles, late in the season succeeded by cleistogamous flowers bearing fruit; the lowermost petal saccate 
or spurred, and the lowermost two stamens appendaged, Viola, Violet

1. Acaulescent,

1. Caulescent, - - - - - - - - - - -6

2. White, - - - - - - - - - - - - 3

2. Blue, purple, lilac, - - - - - - - - - - - 4

3. Leaves oval to ovate-oblong, the base truncate or subcordate, the margins entire or crenulate; sepals acuminate; petals veined with purple, almost beardless. Moist soil. Spring. - - V. primulaefolia

3. Leaves lanceolate, decurrent upon the petiole, the margins obscurely crenulate; petioles longer than the blades; scapes not longer than the leaves; sepals acuminate; petals beardless, the lower three witb purple veins. Moist soil. Spring. - _ - V. Lanceolata

4. Petals not bearded; - leaves roundish, pedately divided into 5-11 linear lobes; corolla blue, pale-lilac, rarely white. Dry woods. Spring. V. pedata

4. Petals bearded, leaves undivided,

5. Leaves long-petioled, mostly upright, reniform to cordate-ovate, obtusely serrate, the sides at the base rolled-in when young; corolla blue, lateral and often the lower petals bearded. Low ground. Winter and Spring. - _ - _ - - V. cucullata

5. Leaves cordate, crenate; flowers blue or variegated with white; fragrant. Cultivated. - - - _ - V. odorata, Sweet violet

6. Stem simple, erect; cauline leaves short-petioled, hastate, denticulate; basal leaves, if any, cordate; corolla small, yellow, lateral petals bearded, the lowest with purple veins; spur very short. Sandy woods. Spring and Summer.

V. hastata

6. Stem branching; upper leaves oblong-ovate, lower ones ovate-cordate, deeply crenate; stipules large; fowers blue-whitish-yellow, but one of the colors may strongly predominate, or blue may be intensifed to purple, violet or purple-black. Cultivated. V. tricolor, Pansy

\section{Passifloraceae, Passion Flower Family.}

Herbs or shrubs, often climbing by means of tendrils from the axils of the leaves; with alternate, mostly stipulate leaves, and usually showy, axillary flowers; sepals $4-5$, more or less united; petals $4-5$, together with a filamentous crown inserted in the throat of the calyx; stamens 4-5, monadelphous below, and enclosing the stalk of the ovary; ovary 1-celled, with 3-4 parietal placentae; styles 3-4, club-shaped; fruit fleshy, berry-like; seeds numerous, included in a pulp.

Leaves entire. lobed or parted; flowers solitary or clustered; calyx sometumes colored; petals rarely wanting; crown-filaments in rows; antbers versatile; stigmas capitate; seeds flattened.

Passiflora, Passion-flower

P. incarnata, May-Dop. Trailing or climbing vine; leaves palmately 3-5 lobed with two glands at the base of the blade; peduncles 3-angled, bearing an anvolucre of 3 ovate bracts; sepals with a horn near the apex, greenish outside. tioged with lavender inside; petals pale-lavender; flaments in about 
5 rows, lavender striped with dark-purple and white; berries oval, yellowish, large. Open and cultivated ground. Summer.

P. lutea. A slender climber with 3-lobed leaves, the petioles without glands; peduncles without involucre; corolla greenish-yellow, filaments in 3 rows, berries oval, purple. Woods and thickets, and cultivated. Summer.

P. quadrangularis, cultivated as Granadilla-vine has white, violet and red flowers, and large pale yellow fruits with edible pulp.-P. Pfordtii with bright blue flowers is hardier.

\section{Opuntiaceae (Cactaceae), Cactus Family.}

Succulent shrubby plants, commonly provided with spines arising from bristly areolae; stems globose, columnar (round or angular), or flattened (jointed or continuous); leaves scale-like or wanting; flowers usually large, solitary, terminal or lateral; sepals and petals similar, in several rows; stamens numerous, in rows, inserted on the base of the petals; ovary inferior, 1-celled, with several parietal placentae; style $\mathbf{1}$, with stigmas as many as placentae; fruit a fleshy berry, rarely dry, smooth or spiny; seeds numerous.

Stems jointed, joints flat or more or less terete; leaves scale-like or fleshy; spines barbed (in one species wanting); flowers lateral, arising from spine-bearing areolae; calyx spreading, corolla rotate, stigma 5-8 lobed, fruit pear-shaped, - - - Opuntia, Prickly Pear

O. Opuntia (vulgaris). Stems ascending or prostrate; joints flat, as long or almost twice as long as wide; bristle-cushions remote, with solitary short spines and often without them; bristles few; flowers pale-yellow; fruit nearly smooth. Dry sandy soil. Summer and Fall.

O. Pes-Corvi. Stems spreading or prostrate; joints nearly terete, many times as long as wide, easily separable; bristle-cushions numerous, the upper ones armed with 1-3 slender spines; flowers yellow; fruit small, bristly. Sandy places along the coast. Early Summer.

O. tuna, Tuna cactus. Cultivated for the juice of its purplish-red pear-shaped fruits; flowers yellow or reddish; erect and spiny, about $1 \mathrm{~m}$. tall.

O. ficus-indica. Erect and almost spine-less, 1-2 m. tall; flowers yellow; cultivated for its fruit.

Burbank's spine-less cactus is cultivated for cattle fodder near DeLeon Springs.

Some species of the following genera are cultivated for ornament:

a. Echinocactus, almost globular, strongly ribbed, flowers terminal.

b. Cereus, from almost globular to columnar; branching, stout, slender, climbing or creeping; ribbed or angled. The species C. grandiflorus and C. nycticalus are known as the fragrant. Night-blooming Cereus.

c. Echinocereus, like the columnar forms of Cereus, but smaller.

d. Phyllocactus, mostly epiphytes with flat joints. To this genus belongs Epiphyllum truncatum, Crab-cactus, with red flowers growing horizontally from the truncated ends of the younger joints. Winter and early Spring.-Also Phyllocactus latifrons, Queen Cactus, stems broad and flat, with creamy white flowers and reddish tube, blooming at night. 


\section{Begoniaceae, Begonia Family.}

Herbs or shrubby plants with alternate, commonly inequilateral, toothed or lobed leaves; flowers in cymes, moncecious; the sterile ones with 2 -more sepals, 5 or less minute petals, and numerous stamens; the fertile ones with calyx and corolla, inferior 1-several celled ovary, the styles partly united, and twisted or coiled stigmas; fruit a winged capsule.

Flowers with colored perianth, stamens many; ovary winged, 3-celled; style short, stigmas spirally twisted; capsule membranous, unequally 3-winged. Species all cultivated, - - - - - Begonia

\section{Proteaceae, Protea Family.}

Herbs, shrubs or trees, mainly with alternate, simple or compound leaves, and perfect flowers; perianth of 4 partially united sepals; stamens 4 , adnate to the sepals; ovary superior, 1-celled, and ovules 1-2; fruit often a follicle.

Shrubs or trees with pinnately parted leaves, and flowers in terminal racemes; tube of perianth cleft with style protruding; anthers sessile and ovary stalked, - _ _ - _ - - Grevillea

G. robusth, Ausiralian Silk Oak. Evergreen tree with bipinnately parted leavas and narrow, more or less incised segments; racemes long. Cultivared. Spring.

\section{Elaeagnaceae, Oleaster Family.}

Shrubs and trees with silvery scaly foliage; leaves opposite or alternate, entire; flowers perfect, polygamous or dioecious; sepals 4 or 2 ; corolla absent; stamens 4 or 8 ; ovary 1-celled with 1 ovule, style 1 ; fruit an achene enclosed in the calyx, making it drupe-like.

Shrubs with alternate leaves, silvery beneath, and perfect or polygamous

flowers in the axils; sepals and stamens 4. Cultivated. Elaeagnus, Oleasber

E. edulis (longipes), Coumi. Evergreen leaves; flowers yellowish-white in Spring; fruit scarlet in Summer.

E. pungens. Evergreen leaves, variegated in some varieties; flowers in Fall, fruit in Spring.

\section{Lauraceae, Laurel Family.}

Trees and shrubs with exstipulate simple leaves, and perfect, polygamous, or dicecious flowers; perianth imbricated in two rows, of 6 , rarely $4-10$ parts; stamens 6 or more in 2-4 rows; ovary free, 1-celled, 1-ovuled, style 


\section{simple, stigma entire or 3 -lobed or styles 3 ; fruit a drupe with solitary seed.}

1. Deciduous; flowers mostly diccious, stamens 9 in 3 rows;-leaves alternate; flowers yellowish green, appearing before the leaves, in axillary cymes, umbel-like; the third row of stamens with two orange-colored glands at the base, - _ - _ - Sassafras

S. sassafras (officinalis). Small tree with oblong, mostly 3-lobed leaves; drupe red or orange. Old fields. Spring.

1. Evergreen; flowers perfect, stamens 12 in 4 rows, one of staminodia, - - 2

2. Flowers in axillary peduncled cymes; perianth persistent, - Tamala (Persea)

T. Borbonia (P. Carolinensis), Red Bay, Sweet Bay, Florida Mahogany. A tree with elliptic leaves; fruit dark blue or black. Woods on riverbanks, and planted. Summer.

T. pubescens (P. Carolinensis, var. palustris). Tall shrub with narrowly elliptic leaves; drupe dark-blue with a thin bloom. Ponds and river hammocks. Summer.

2. Flowers in terminal panicled cymes; perianth deciduous, _ _ - Persea

P. Persea, Arocado, Alligator-pear. An ornamental tree with elliptic to oval leaves; fruit edible. Cult. (Flowers and fruit seldom seen here.)

2. Flowers in axillary panicled cymes; perianth deciduous, - - Camphora

C. camphora, Camphor-tree. A tree, planted for gum-production and shade; flowers white; styles 3 , slightly adherent below.

\section{Melastomaceae, Meadow Beauty Family.}

Herbs, shrubs and trees with opposite, exstipulate leaves and mostly showy, perfect flowers, calyx 3-6 lobed; petals $3-6$, inserted with the $3-12$ stamens on the throat of the calyx; anthers appendaged; ovary free, 2-many but often 4-celled, with numerous ovules; style 1; fruit berry-like or capsular, 2-many celled, many-seeded.

Herbs with horizontal rootstalks; leaves usually 3-5 veined; flowers solitary or in terminal cymes; calyx urn-shaped, sepals and petals 4; stamens 8, exserted; ovary 4-celled; capsule 4-celled, seeds rough, coiled or bent, - - - - - - Rhexia, Deer-grass

1. Anthers short, oblong, erect, not spurred, - - - - - - - 2

1. Anthers long, linear, curving upward, spurred, - - - - - -4

2. Corolla purple, pink, or white, - - - - - - - $~ 3$

2. Corolla yellow; - stem 4-angled, simple, bristly; leaves smooth, bristly serrulate, the lower obovate, the upper lanceolate; flowers nearly sessile, numerous, small. Low pine-barrens. Summer, - - R. lutea

3. Calyx-tube glandular-bristly; upper surface of leaves smooth;-stem 4-angled, sparingly branched, smooth below; leaves ovate, bristly-serrulate; flowers solitary or in cymes, purple. Pinebarrens. Summer.

- R. serrulata

3. Calyx-tube smooth; upper surface of leaves bristly;-stem 4-angled, branches ascending, nearly smooth; leaves broadly ovate, bristlyserrulate; flowers in cymes, purple or deep pink. Sandy swamps. Summer.

R. ciliosa

4. Neck of the mature calyx as long as the globose capsular portion, or 
longer; leaves lanceolate, with 3 prominent veins;-stem vil. lous-hirsute, imple or branched, nearly terete; flowers in cymes. pale or deep-purple. Sandy swamps. Summer and Fall, R. Mariana

\$. Neck of the mature calyx shorter than the globose capsular portion; leaves lanceolate to linear, almost entire, leathery; - stem obscurely 4-angled, glabrous; flowers in cymes; petals purple. Moist pine-land. Summer. - _ _ _ - - R. glabella

\section{Lythraceae, Loosestrife Family.}

Herbs, shrubs or trees with exstipulate leaves and perfect flowers, solitary or in inflorescences; calyx tubular, 4-7 toothed, the sinuses often appendaged; petals as many as the teeth of the calyx, and inserted in its throat, sometimes wanting; stamens as many as the petals, or 2-4 times as many, inserted below the petals; ovary $2-6$ celled, free; style 1 ; fruit a capsule.

1. Calyx cylindrical, fluted;-herbs with angled stems and opposite or alternate entire leaves; flowers axillary or in terminal spikes or racemes; ovary 2-celled, - _ - _ - _ - Lythrum

L. lineare. With 4 -angled branching stems and opposite, linear, sessile leaves; flowers dimorphous, pale-purple or pink. Marshes near the coast. Summer.

L. lanceolatum. With angled or slightly winged stem and strongly ascending branches; leaves chiefly alternate, elliptic, sessile; flowers purple; stamens included. Low ground. Summer.

1. Calyx campanulate or turbinate, - - _ - - - $~ 2$

2. Herbs with inconspicuous flowers;-stem 4-angled; simple or branched; flowers solitary or cymose, axillary; calyx 4 , often with 4 teeth in the sinuses; petals 4 ; stamens $4-8$; ovary $2-4$ celled. Ditches. Late Summer. - - - _ - - - - Ammannia

A. Koehnei (latifolia). Leaves spatulate or oblanceolate; flowers 1-3, pinkish.

A. coccinea. Leaves linear to lanceolate; flowers $1-5$, Durplish.

2. Aquatic shrubs; -leaves opposite or whorled; flowers in axillary cymes. purple; caly $\mathbf{x} 4-7$, with teeth in the sinuses; petals 4-7; stamens 10 or 8; ovary 3-6 celled; capsule 3-6 valved. - - Decodon

D. verticillatus (Nesaea verticillata), Swamp Loosestrife. The submerged portio $\square$ of the stem coated with spongy tissue; leaves lanceolate, often undu. late. In marshes and ponds. Summer.

2. Shrubs or small trees, Cultivated.

3. Opposite or whorled branches, and mainly opposite leaves; fowers showy in terminal panicles; calyx 6-parted; petals 6, crisped; stamens numerous; ovary $1-6$ celled, capsule 3-6 valved; seeds flattened, winged above.

Lagerstroemia

L. Indica, Crope-myrlle. Petals purple, pink or white. Summer.

3. Somewhat spiny branches with opposite leaves; frasrant flowers in spikes and panicles; calyx 4-parted; Detals 4 stamens 8; capsule r-celled.

Lawsonia, Ненna Bush*

L. alba inermis and L. rubra, resp. with white and red fiuwers. 


\section{Punicaceae, Pomegranate Family.}

Shrubs with opposite, entire, exstipulate leaves, and showy, perfect flowers; calyx 5-7 parted; petals 5-7, inserted on the throat of the calyx; stamens numerous in rows, with versatile anthers; ovary several-celled, inferior; style 1, or styles 5 united at the base; ovules numerous; fruit a several-celled berry with a leathery coat, and membranous septa; seeds in a watery pulp.

Leaves oval to oblong, short-petioled, deciduous; peduncles axillary, 1several flowered; calyx-lobes shorter than the tube; petals scarlet; berries subglobose, one-half to one $\mathrm{dm}$. in diameter. Late Spring. Cultivated in single and double varieties.

Punica granatum, Pomegranote

\section{Myrtaceae, Myrtle Family.}

Shrubs or trees with opposite or alternate, exstipulate, punctate leaves, a vein running close to and parallel with the margin; flowers perfect; calyx 4-5 lobed; petals as many as the calyx-lobes, or wanting; stamens usually numerous with filaments distinct or partially united; ovary inferior or partly so, 1-many celled; style and stigma 1; ovules 1-numerous; fruit a berry or (in EUCALYPTUS) a capsule.

Calyx 5-lobed, petals 5; stamens exserted. Evergreens. Cult. - - - 1

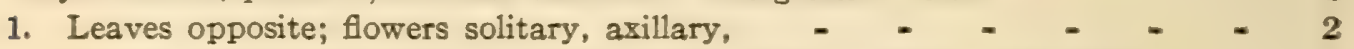

1. Leaves alternate; flowers in dense lateral cymes;-shrub with thick,

lanceolate leaves; flowers with numerous crimson stamens. Spring.

Callistemon lanceolatum, Bottle-Brush

1. Leaves alternate, flowers 3-many, usually white, in umbels, the latter solitary and axillary, or panicled near the end of the branchlets;-tall trees with simple, entire leaves, broadly ovate to lanceolate and falcate, acuminate; stamens numerous, usually distinct. The hardiest species are: E. vimimalis, Manna Gum; E. obliqua, Messmate or Stringy-bark; E. polyanthema, Australian Beech: E. resinifera, Kino; E. rostrata, Red Gum etc, - - - - - - - - Eucalyptus, Gum-tree

2. Sepals equal;-shrub with ovate, shining leaves; flowers white or rose-tinged. Spring or Summer, - Myrtus communis, Sweet Myrtle

2. Sepals unequal; - tall shrub with oblong leaves in which the lateral veins are prominent; berry pulpy, edible. - Psidium Guajava, Guava

\section{Rhizophoraceae, Mangrove Family.}

Maritime shrubs or trees, with stipulate, leathery leaves; flowers perfect, solitary in the axils, or variously clustered; sepals and petals $3-4$; stamens 2-4 times as many as the petals, inserted at the base of a disk; ovary inferior 
or partly so, $2-5$ celled; styles united; fruit a leathery berry crowned with the calyx.

Evergreen shrubs or trees with opposite, entire leaves; stipules caducous; flowers cream-colored or jellow in peduncled clusters of 2-several; sepals and petals 4; stamens 4-12; ovary 2-celled, half inferior; stigma 2-lobed; ovules 2 in each locule. - - - Rhizophora

R. Mangle, Mangrove. Forms thickets on salt or brackish shores; leaves elliptic to elliptic-obovate, with a conspicuous midvein; flowers pale-yellow.

\section{Epilobiaceae (Onagraceae), Evening-primrose Family.}

Herbs, rarely shrubs, with alternate or opposite, exstipulate, simple leaves; flowers usually perfect, often with an elongated calyx-tube; calyx $2-6$ lobed, petals $2-9$; both calyx and corolla usually in 4's or the latter sometimes wanting; stamens as many, or twice as many as the petals; ovary 1-6, usually 4-celled, inferior; style 1 , stigma capitate or lobed; fruit a capsule, sometimes nut-like; seeds sometimes appendaged.

1. Fruit a dehiscent capsule,

1. Fruit nut-like, indehiscent; - herbs with alternate leaves; flowers in terminal spikes or racemes; calyx-tube prolonged, the limb $3-4$ lobed; petals $3-4$, unequal; stamens 6-8; stigma 4-lobed, surrounded by a cup-like border; fruit 1-4 seeded.

Gaura

G. angustifolia. Stem simple or sparingly branched, pubescent; leaves spatulate to linear, often blotched with purple; petals white or pink; fruit 4 -angled. Sandy soil. Summer.

2. Calyx-tube not prolonged beyond the ovary, - - - - - - 3

2. Calyx-tube prolonged beyond the ovary, - - - - - - - 5

3. Stamens 4 in 1 row.

3. Stamens $\&-12$ in 2 rows; - marsh-herbs or shrubby plants with alternate leaves; flowers axillary; calyx 4-6 lobed; petals $4-6$, white or yellow; ovary 4-6 celled,

Jussiaea

J. leptocarpa. Stem erect, branched, bristly-hirsute; leaves lanceolate, nearly sessile, hairy; calyx-lobes mostly 6 , as long as the petals, corolla yellow. Marshes. Summer.

J. scabra. Stem often woody, hirsute; leaves ovate to obovate, pubescent; calyx 4-lobed shorter than the petais, corolla yellow. Moist soil. Spring to $\mathrm{Fall}$.

J. grandiflora. Stem decumbent, villous; lower leaves spatulate, the others lanceolate or elliptic; calyx 5-lobed; petals suborbicular, yellow. Ponds. Summer and Fall.

4. Stems creeping or floating; leaves opposite;-succulent herbs with small, axillary. sessile fluwers; calyx-tube 4-lobed; stamens very short; style almost wanting. Late Spring and Summer.

Isnardia (Ludwigia), Marsh Purslone

I. (L.) spathulata. Hairy; flowers without corolla. Around pine-land ponds. 
I. (L.) palustris. Smooth; petals reddish or wanting. Swampy places.

I. (L.) natans. Smooth; flowers with inconspicuous corolla. Marshes.

4. Stems erect or ascending; leaves alternate;-herbs with axillary or terminal 4-parted flowers. Summer and Fall. - - - Ludwigia

L. pilosa. Stem woody, much branched, pilose; leaves sessile, lanceolate or oblong; flowers in terminal spikes; petals mostly wanting. Ponds near the coast.

L. lanceolata. Stem stout, at length branched, smooth; leaves sessile, lanceolate; flowers small in all the axils; petals wanting. Pine-barren ponds.

L. microcarpa. Stem slender, 3-angled; leaves short-petioled, spatulate or orbicular; flowers axillary, inconspicuous, petals wanting. Muddy places.

L. a!ata. Stem slender, narrowly winged; leaves linear, lanceolate; flowers inconspicuous, petals wanting. Marshes.

L. linifolia. Stem low, glabrous, 4-angled, often purplish; leaves linear, sessile; flowers sessile, inconspicuous; petals as long as the sepals. Swampy pineland.

L. linearis. Stem branching, glabrous; leaves narrowly linear, sessile; flowers sessile, petals slightly longer than the sepals, yellowish. Swamps.

5. Leaves undulate or toothed; flowers in terminal spikes, sepals elongated; ovules in 2 or more rows, horizontal; capsule erect, tapering, - - - - - - - - - Onagra (Oenothera)

O. biennis. Stem stout, hirsute; leaves oblong to lanceolate; sepals slender, corolla bright yellow. Dry soil. Summer and Fall.

5. Leaves sinuate or pinnatifid; flowers mostly axillary; sepals deciduous; ovules in 2 rows, ascending; capsule narrowly-cylindric; seeds terete, crowned with a tubercle, - Oenothera, Evening Primrose

O. laciniata (sinuata). Stem ascending or diffuse, smooth or downy; leaves oval, oblanceolate to spatulate, sinuate-dentate or pinnatifid; seeds strongly pitted. Dry sandy soil. Spring and Summer.

O. humifusa. Stem with spreading branches near the base; basal leaves oblongspatulate, pinnatifid; cauline ones lanceolate, undulate, toothed; seeds striate. Sand along the coast. Spring and Summer.

5. Leaves ovate, dentate; flowers drooping, axillary; calyx tubularfunnel form, colored, limb 4-lobed; petals 4; stamens 8 , exserted, style long-exserted. Cultivated. - - _ - - - Fuchsia

F. coccinca. With scarlet sepals and violet-purple petals;-F. fulgens with bright red flowers;-and other varieties.

\section{Gunneraceae (Halorrhagaceae), Water-Milfoil Family.}

Aquatic herbs with alternate or whorled leaves, the submerged finely divided, the emersed entire or toothed; flowers perfect or monœcious, axillary or terminal.

1. Stems creeping, leaves toothed or the lower dissected; flowers perfect, minute, greenish, axillary; calyx 3-4 angled and lobed; petals none; stamens $3-4$, included; ovary $3-4$ celled, inferior; stigmas $3-4$; fruit nut-like. In wet soil or in pools. Spring to Fall. Proserpinaca

P. pectinata. All leaves nearly alike; sepals ovate, erect.

P. palustris. Leaves of two kinds; sepals triangular, ascending.

1. Stems commonly floating, leaves of two kinds; flowers monœcious, minute, axillary or in terminal spikes with the upper ones sterile, 
the intermediate perfect. and the lower ones pistillate; the sterile flowers with a $2-4$ toothed or truncate calyx, 2-4 petals and $4-9$ stamens; the fertile Howers with a 4 -gronod calyx, minutely toothed; 4 small petals or none, and a 1 -celled ovary with 2.4 often plumose stigmas. In ponds and slow streams. Summer.

Myriophyllum, Water Milfoil

M. verticillatum. Slender; submerged leaves in whorls of 3 or 4. crowded, the emersed pectinate-pinnatifid; sterile flowers with 4 purple hooded petals and 8 stamens; fruit smooth.

M. heterophyllum. Stout; submerged leaves crowded, with hair-like segments, the emersed in whorls of 3 to 6 . linear to lanceolate, serrate; sterile flowers with 4 oblong petals and $4-6$ stamens; fruit roughened.

M. proserpinacoides, Parrol's Feather. Leaves in whorls of $4-5$; flowers dix. cious. Cult ivated in fountain-vases.

131. Nyssaceae (Cornaceae), Dogwood Family.

Trees or shrubs with exstipulate simple leaves; flowers in cymes or heads; calyx 4-5 toothed; petals $4-5$, or wanting; stamens 4-10, inserted with the petals at the base of an epigynous disk; ovary inferior, 1-4 celled; style 1. stioma entire or lobed or cleft; ovules solitary in each cell; fruit a drupe with acid pulp.

1. Flowers in dichotomous cymes without involucre;-leaves opposite; calyx 4-toothed or lo'sed; petals 4 , white; stamens 4 ; ovary 2 celled; drupe with thin pulp. Low woods along the river. Spring. - - - - - - - - Svida, Dogwood, Cornel

S. (Cornus) stricta. Twiss reddish brown, leaves smoth beneath, drupes pale blue.

1. Flowers in a head subtended by a large white or pinkish involucre:leaves opposite, prominently veined; calyx 4 -lobed; petals 4 . greenish; stamens 4 ; ovary 2-celled; drupes red, clustered. In oak woods and planted. Spring.

C. floridum (Comus florida), Flowering Dogwood. Leaves pubescent; stamens exserted.

132. Hederaceae (Araliaceae), Ivy Family.

Herbs, shrubs, trees or vines, cultivated for ornamental or, as the Ginseng, for commercial purposes. Flowers perfect or polygamous; calyx 5-toothed or truncate; petals and stamens $5-10$, both inserted in the margin of an epigynous disk, alternate; ovary $2-5$ celled, inferior; styles 2-5, sometimes united; ovules solitary; fruit a berry or drupe.

1. Vines with simple leaves; - sers joartel. styles united. fruit a bersy,

Hedera

H. Helix, 1ry. Leaves evergreen. $3-5$ thined or cleft; curolla seliumsh green.

1. Herbs, shrubs or trees with compound leaves. 
2. Scapose;-herbs with simple scapes topped by a whorl of digitately compound petioled bracts; flowers inconspicuous, in simple terminal umbels; calyx truncate; petals 5 , greenish; ovary 2-3 celled; styles 2-3; fruit drupe-like, red or yellowish, - - Panax

P. quinquefolium, Ginseng. Whorl of 3-4 long-petioled bracts; leaves 5-7 foliate; berries bright crimson. Cultivated without success.

P. excelsum and P. plumatum with ferny leaves, or P. aureum and P. victoriae with variegated leaves, are fine house-plants.

2. Caulescent;-herbs or shrubs with pubescent or prickly-armed foliage; leaves pinnately or ternately decompound; flowers white or whitish, 5 parted, in racemose or paniculate, or compound umbels; berries black,

A. spinosa, Prickly Ash. Shrub or small tree with large, long-petioled leaves; numerous umbels of flowers in panicled racemes. River-hammock. Summer.

A. filicifolia with fern-like leaves, A. Guilfoylei with variegated foliage, and A. papyrifera, the Chinese rice-paper plant, with its large leaves belong to this genus.

\section{Ammiaceae (Umbelliferae), Carrot or Parsley Family.}

Herbs with hollow stems and generally alternate, more or less dissected leaves; flowers umbellate, either compound, or the umbels contracted into heads, perfect or polygamous; umbel and secondary umbels (umbellets) often subtended by an involucre and involucles (bracts and bractlets); calyx 5-toothed or with a mere border; petals 5 and stamens 5, inserted together on an epigynous disk; ovary inferior; styles 2, often united and thickened below; fruit dry (CREMOCARP), composed of 2 indehiscent carpels (MERICARPS), suspended from a filiform axis (CARPOPHORE), and cohering by their inner face (COMMISSURE); each with 5 primary and often with 4 secondary ribs; the intervening spaces (INTERVALS) usually containing channels (VITTAE) filled with oil; seeds solitary.

1. Flowers in simple umbels, or the umbels forming an interrupted raceme; - herbs with creeping stems in damp or wet ground; leaves palmately lobed or peltate; flowers small, white; involucre absent.

Early Summer. - - - - Hydrocotyle, Marsh Pennywort

H. umbellata. Leaves peltate, crenate-lobed; umbels many-flowered; fruit notched.

H. Verticillata (interrupta). Leaves peltate, shallowiy crenate; umbels fewflowered forming an interrupted raceme; fruit rounded or truncate.

1. Flowers in capitate long-peduncled umbels;-herbs with creeping stems in sand or moist pine-land; leaves palmately veined, with long petioles clustered at the nodes; flowers small, white; bracts of the involucre 2-4. Early Summer. - - Centella Pennywort

C. (Hydrocotyle) repanda. Leaves ovate to cordate, umbels 2-4 flowered.A form with short petioles is var. Floridana. 
1. Flowers in dense capitate or elongated spikes:-herbs with erect or creeping stems and mostly spiny-torthed leaves; calyx-lobes acute or spinous; petais inflexed; fruit slightly flattened laterally. Spring and Summer. - - Eryngium, Bullon Snake-root

E. Baldwinii. Stems with slender branches at the base; basa! leaves oblong: long-petioled; stem-leaves 3-parted with linear segments; bracts and bractlets subulate; fruit tuberculate. In sandy soil.

E. Floridanum. Stems sparingly branched; basal leaves narrowly oblong. longpetioled; upper-leaves long-linear, sessile; bracts and bractlets linear, sharppointed; fruit crowned with the calyx. In brackish marshes.

E. aromaticum. Stems with ascending branches at the base, corymbose near the top; leaves pinnately parted; setaceous to spine-tipped; bracts 3-cleft, bractlets 3-toothed; fruit crowned with the calyx. In dry pineland.

E. aquaticum (yuccafolium). Stems corymbose above; leaves linear, bristly on the margins, their bases folded around the stem; bracts and bractlets lanceolate, strongly veined; fruit scaly. In low ground.

1. Flowers in compound umbels, - - - - - - - - - 2

2. Fruit smooth or slightly roughened, - - - - - - - 3

2. Fruit with a row of barbed bristles on the winged, secondary ribs; caulescent herbs with rough-pubescent foliage; leaves pinnately decompound; involucres and involucels various or wanting; calyx truncate; petals white, often unequal; fruit dorsally flattened,

Daucus, Carrot

D. Carota. Stems channeled; flowers white, the central one of the umbel often purple. Cultivated.

2. Fruit armed with hooked bristles. carpels without ribs;-caulescent herbs; leaves pinnatifid or palmately 3-7 foliate; flowers usually uniseral, in irregular compound few-rayed umbels; bracts of the involucres resembling the leaves; sepals 5 , petals emarginate, white, yellowish or purple; fruit somewhat dorsally flattened, - - - - - - Sanicula, Black Srake-rool

S. Floridana. Stems solitary, leafy, branched; leaves $3-5$ parted with yellowish spiny-cuspidate teeth; branches of the umbel slender, dichotomous; sterile flowers 1-3, nearly sessile; involucre of minute bracts; fruit very small. Sandy soil. Summer.

3. Pruit laterally flattened; wingless, - - - - - - - - 4

3. Fruit dorsally fiattened, - - - - - - - - - 8

4. Calyz-limb minute or none, - - . - - - - - 5

4. Calyx-limb 5-toothed:-herbs with tuberous roots and pianately com. pound or decompound leaves; bracts few or none, bractlets small, several; petals white, the tips inflexed; fruit slightly flat. tened. In marshes. Summer.

Cicuta, Woier Hemlock or Poison Hemlock

C. maculata. Stems tall, with purple ridges, branching above; leaves twice or thrice compound, petioles of lower leaves long. those of upper leaves short and dilated; bracts linear-subulate, deciduous; rays numerous, unequal; flowers white; fruit oval or ovoid, not constricted at the commissure; vittse large.

3. Lesves dissected into narrow segments;-slender branching herbs; no bracts and oniy a few nartow bractlets; petais wh:te; fruit slightly flattened, tuberculate; seeds angled.

Spermolepis (Leptocaulis) 
S. (L.) divaricatus. Stems with slender branches; leaves twice or thrice pinnately parted. Sandy soil. Spring.

5. Leaves pinnately or ternately compound, leaflets toothed, pinnatifid or dissected,

6. Calyx-teeth obsolete,

6. Calyx-teeth acute;-caulescent herbs with pinnately-compound leaves; involucres and involucels of narrow bracts; petals white; fruit stout; seeds 5-angled,

Sium, Water Parsnip

S. cicutaefolium (lineare). Leaflets $7-17$, sharply serrate; submerged leaves, sometimes finely dissected; umbels peduncled. In shallow water. Summer and Fall.

7. Petals concave, not emarginate;-caulescent herbs with pinnately or ternately decompound leaves, and toothed or incised leaflets; involucres present or wanting; petals white; seeds terete or slightly angled,

A. graveolens, Celery. Leaves on long petioles, pinnately divided; segments broad-cuneate, incised; upper-leaves 3-parted and cut-lobed; involucres wanting. Cultivated.

7. Petals emarginate, inflexed;-caulescent herbs with pinnately or ternately decompound leaves; involucres various; petals white; seeds sub-terete. Cultivated.

Carum

C. petroselinum, Parsley. Leaf-segments numerous, wedge-ovate to oblong, incised; bracts few or none, bractlets subulate.

C. carvi, Caraway. Leaf-segments numerous, linear; bracts 1 or none, bractlets none; fruit oblong, aromatic.

8. Ribs prominent and the lateral ones broadly winged;-caulescent herbs, strongly scented; involucres and involucels present or wanting; petals white or greenish, broadest above the middle. Angelica

A. dentata. Stems simple or branching above; leaves glabrous, ternately decompound, on long petioles; leaflets oblong to oblanceolate, incised-serrate; umbels few or solitary; rays 5-12; oil-tubes about 20. Dry pineland. Summer.

8. Ribs thin and the lateral ones winged;-caulescent marshy herbs with smooth foliage; bracts and bractlets 5-6; flowers white. Summer and Fall. - _ - - - Oxypolis (Tiedemannia)

O. fliformis ( $T$. teretifolia). Stems simple or branched above; the leaves reduced to elongated, hollow, jointed phyllodes; bracts subulate; rays slender 6-16. Swamps. Summer and Fall.

O. ternata. Stems somewhat branched; leaves entire or divided into 3 linear leaflets; rays very slender. Low ground. Fall.

\section{Monotropaceae, Indian Pipe Family.}

Herbs, saprophytic on decayed vegetable matter, or parasitic on roots; the scape-like stems solitary or clustered; leaves reduced to scales, which are often imbricated; flowers usually perfect, solitary, nodding; sepals 2-6, imbricated; petals 3-6, distinct or partially united, rarely wanting; stamens $6-12$, distinct or united at the base; ovary 
superior, 1-6-celled; pistil 1, ovules numerous; fruit a capsule; seeds minute.

Monotropa uniflora. White or pink, succulent, wax-like herbs, turning slatecolored in drying. usually found in clusters; flowers solitary, noddinz; sepals 2-4; retals 5-6, with stiff hairs on the inside; stamens 10-12, with peltate anthers; ovary 5-celited, cunfluent with the calyx-disk beneath; stigma funnelform; capsule 5-celled, oltusely angled. In moist woods. Late Summer and Fall.

\section{Ericaceae, Heath Family.}

Herbs, shrubs or trees with alternate, opposite or whorled, exstipulate leaves and perfect flowers; sepals and petals $4-7$, distinct or partially coherent; stamens as many or trice as many as there are petals or corolla-lobes; filaments usually distinct, with the anthers often awned; ovary free, 2-6 celled, with styles united; ovules numerous; fruit a capsule.

1. Corolla polypetalous;-evergreen branching shrubs, with alternate, leathery leaves and $6-7$ parted flowers in terminal racemes or corymbs; calyz often sticky,

B. racemosa. Leaves oblong to oval, glabrous; corolla white. Sandy soil. Summer.

1. Corolla monopetalous,

2. Corolla funnelform; - shrubs with alternate deciduous leaves, and 5parted flowers in terminal clusters.

A. serrulata. Flowers white, appearing after the leaves; leaves smooth, serrulate with bristle-tipped teeth; pedicels and corolla-tube glandular-hirsute.

A. viscosa, Swamp Honeysuckle. Leaves oblong to obovate, short petioled; corolla white or pink; tube dilated near the limb. Swamps. Early Summer.

The single varieties of Azalea indica in different colors are cultivated.

2. Curolla cup-shaped or rotate, with acute lubes;-low evergreen shrub with hirsute foliage; leaves alternate, small, numerous; flowers pale or deep pink, similar to the preceding, usually solitary on slender pedicels, numerous,

\section{Kalmiella}

K. hirsuta, Wicky. Much branched, hirsute; margins of the leaves revolute; calyx bristly; corolla rose-purple. Pine-barrens. Summer.

2. Curolla salverform;-creeping evergreen shrubs with alternate leaves; 5-parted flowers perfect or divecious in axillary clusters; calyx subtended by several bracts, - - Epigaea, Trailing Arbutus

E. repens. Bright green foliage and white or pink corolla nearly twice as long as the calyx. Dry sandy soil. Spring.

2. Corolle subglobose, urceolate or cylindrical,

3. Calyx usually with several bracts and sepals distinct; corolla ovoidcylindrical; - shrubs with alternate leaves and 5-parted flowers in one-sided racemes or axillary umbel-like clusters; anthers or filaments awned. Spring.

P. (Andromeda) nitida, Feller Bush. Evergreen; flaments 2-awned near the apex; flowers white to red. Low pine-land. 
P. (Andromeda) Mariana, Stagger Bush. Deciduous; filaments 2-awned near the apex; flowers white or pinkish. Damp soil towards the coast.

3. Calyx without bracts; sepals often slightly united; corolla subglobose to urn-shaped;-shrubs with alternate leaves, sometimes persistent; flowers 4-6 parted, small, in racemes or panicles; anthers and filaments awnless. Eariy Summer. - _ - Xolisma

X. (Andromeda) ferruginea. Evergreen shrub or small tree with scurfy twigs and under-side of leaves; very leafy; flowers white or pinkish. Pine-barrens.

X. (Andromeda) fruticosa. Evergreen shrub with scurfy foliage when young; leaves reduced towards the end of the branches; corolla pale. Pine-land.

\section{Vacciniaceae, Huckleberry Family.}

Shrubs or small trees with alternate, simple, exstipulate leaves, often persistent, and perfect, regular flowers; calyx and corolla 4-5 parted; stamens twice as many as corolla-lobes; filaments usually flattened, and anthers sometimes 2 -awned; ovary $2-10$ celled; inferior: style 1 ; fruit a Berry or drupe, pulpy.

1. Ovary 10-celled; fruit a berry-like drupe with 10 nutlets;-flowers 5parted in axillary drooping racemes; corolla campanulate to tubular; anther-cells prolonged into terminal tubes. Spring.

Gaylussacia, Huckleberry

G. dumosa. Low shrub, glandular-pubescent; corolla campanulate, waxy white or pink; drupes black. Low sandy ground.

G. hirtella. Shrub, bristly-hispid, the tips of the hairs with minute glands; corolla broadly campanulate, white or pink. Sand.

G. frondosa, Blue Tangle. Shrub, minutely-downy; leaves sprinkled with resinous globules beneath; corolla globose-campanulate, green to purplish; drupes blue, glaucous.

1. Ovary 4-5 celled, or by false partitions 8-10 celled; fruit a manyseeded berry,

2. Flowers $4-5$ parted in terminal or axillary racemes or clusters; corolla campanulate, tubular or urceolate; anther-cells prolonged into terminal tubes. Spring. - - - - Vaccinium, Blueberry

a. Evergreen, - - - - - - _ _ - - - b

a. Deciduous;- flowers white or pale-pink, in racemes, appearing before the leaves; leaves entire; corolla cylindric; berries deep blue, glaucous. Margins of ponds and swamps. - - V. corymbosum, Tall Blueberry.

b. Leaves glandular-toothed; sepals rounded; berries black;-racemes umbel like; corolla rose-red to white. Pine-land. - - - V. nitidum.

b. Leaves bristly-toothed; sepals acute; berries blue;-racemes very short or umbel-like; corolla white. Pine-land. - - - V. myrsinites.

2. Flowers 5-parted in leafy racemes or panicles; corolla campanulate; stamens hairy, anther-cells prolonged in slender tubes.

Batodendron (Vaccinium)

B. (V.) arboreum, Sparkle-berry, Farkle-berry, Tree Huckleberry Leaves numerous, short-petioled, not quite evergreen, oval or obovate, shining 
above, sizhtly paler beneath; com!la campanulate, white or piskish; an. thers inciuded; style exserted; berries b'ack, hardiy edible. Dry sunl. Late Spring.

\section{Armeriaceae (Plumbaginaceae), Plumbugo Fumily.}

Shrubs or acaulescent herbs with perfect regular flowers; calyx 4-5 toothed; corolla hypogynous, the $4-5$ petals distinct or united; stamens $4-5$, opposite the petals with the filaments distinct or united; ovary 1-celled, styles 5 . distinct or united; fruit a utricle or achene, or capsular.

1. Shrub with siternate leaves. clasping: flowers $4-5$ parted in terminal bracted spikes; calyx tubular, glandular; claws of petais united into a slender tube; styles united to near the top; fruit a capsule, - - - - - - - - Plumbago, Leadwort

P. Capensis, a shrub with pale blue flowers; P. coerulea, partiy herbaceous, with blue flowers; and P. coccinea, also partly herbaceous but ta"ier, with scarlet flowers, are cultivated species flowering in Summer.

2. Acaulescent herbs with basal leaves and branched scapes; fowers 5-parted, subtended by bracts; calyx funneiform, n gt giandular; claws of petais distinct or nearly so; styies distinct; fruit a uiri. cle, - - - Limoaium (Statice), Seu Luvender. M srin R)semary

L. Carolinianum (S. Caroliniana). Scapes erect, much branched; caly-tube bristiy to above the midule; corvila pale purple. Sait mashes. Late Summer.

\section{Primulaceae, Primrose Family.}

Caulescent or scapose herbs with alternate, opposite or whorled leaves; flowers perfect; calyx and corolla 4-9 lobed; stamens as many as corolla-lobes and opposite to them, adnate to the tube; ovary superior or partly inferior, 1-celled, with free central placenta; style 1, stigma entire or lobed; fruit a 1-celled capsule, opening by 2-8 valves; seeds 2-many.

Caulescent berbs with altemate, entire les ves; flowers white or pink, in simple or panicled racemes; calyx and coralla 5-lobed; stamens 5. sometumes alternating with staminodia; ovary part. Iy iaferior; capsule 5-valved; sceds aumerous. Early Sur. mer.

Samolus, Wale-pimpermel

S. Coribundus. Racemes sessile or short-peduncled; corolla white, staminodia present. Presh and salt marshes.

5. ebracteatus. Racemes long-peduncled; corolia pink. staraiandia abseot. Brackisb and salt marshes. 
Cultivated in this family is the Cyclamen with the single, 5-parted flowers on scapes.

139. Ebenaceae, Ebony Family.

Trees and shrubs with alternate, entire, exstipulate leaves, and inconspicuous, dicecious or polygamous, regular flowers, solitary or in cymes; calyx and corolla 3-7 lobed; stamens 3-4 times as many as the corolla-lobes, adnate to its tube; ovary 3-many celled, superior; styles distinct or united at the base; ovules 1-2 in each cell; fruit a fleshy berry, rarely a capsule.

Flowers solitary or in axillary cymes; corolla urceolate to salverform; stamens $4-16$ or more, reduced to staminodia in the fertile flowers; ovary 4-12 celled; styles 2-6, distinct; berry round or conic, subtended by the calyx. - _ _ - - Diospyros, Persimmon

D. Virginiana. Tree with deep-brown or black bark and ovate to elliptic, undulate leaves; calyx and corolla 4-lobed, the latter greenish, urn-shaped; staminodia 8 , stamens mostly 16 ; berry globose. Old fields. Spring.

D. Kaki, Japanese Persimmon. Cultivated in different varieties.

\section{Sapotaceae, Sapodilla Family.}

Shrubs or trees, often spiny or thorny, mostly with a milky sap, and exstipulate, alternate, entire leaves; flowers perfect, in axillary clusters; calyx $4-12$; corolla white, 4-several lobed, often appendaged at the sinuses; stamens as many as and opposite to the corolla-lobes, adnate to the tube; staminodia often conspicuous; ovary 4-12 celled, superior; ovules 1 in each cell; styles united; fruit a berry with nut-like seeds.

Shrubs or small trees; sepals unequal; sepals, corolla-lobes and stamens 5; corolla with appendages; staminodia 5, petal-like; berry drupelike. Spring and Summer. - - - - Bumelia, Buck-thorn

B. reclinata. Decumbent or ascending, low, spiny shrub; leaves numerous, obovate, retuse at the apex, shining above and duller beneath, narrowed into petioles; fruit oval. Sandy soil.

B. lanuginosa, Gum Elastic. Shrub or small tree; leaves oblanceolate to elliptic, lower surface with red or brown, dull, woolly pubescence; fruit obovoid. Sandy woods.

B. tenax, Black Haw, Iron-wood. Shrub or small tree, thorny or unarmed; leaves numerous, obovate to oblong-elliptic, obtuse or retuse, slightly revolute, lower surface with silky pubescence, at first whitish but becoming tawny; short petioles; fruit obovoid. Thickets and sandy soil.

\section{Oleaceae, Olive Family.}

Trees or shrubs, rarely herbs, with erect or climbing stems and opposite, simple or pinnately-compound leaves 
without stipules; flowers regular; sepals 4 or more, partially united, or wanting; petals $2-8$ distinct or partially united, or wanting; stamens $2-4$, adnate to the base of the corolla; ovary 2 -celled, superior; ovules 2 in each cavity; fruit a capsule, samara, drupe or berry; seeds commonly solitary or $2-4$.

1. Flowers perfect, corolla present, - - - - - - - - 2

1. Flowers imperfect, corolla wanting or inconspicuous, of $2-4$ petals, distinct or united; fruit a samara;-shrubs or trees; flowers polygamous or dicecious, rarely perfect, in clusters or panicles; calyx wanting or with 4 unequal lobes; stamens 2, rarely $3-4$ : style 1, stigma 2-cleft. Riverswamps. Spring. - - Fraxinus, Ash

F. Caroliniana (platycarpa), Hater-ash, Pop-ash. Shrub or small tree; leaflets 5-9; samaras elliptic to obovate, with the linear body flat and the 2-3 wings pinnately roined.

2. Stamens more or less exserted; - trees or shrubs with evergreen leaves and small, fragrant flowers in axillary racemes or panicles; calyx 4-toothed; corolla white, tube short, with a 4 -lobed spreading border; stmens 2; fruit a drupe, mostly 1-seeded. - - Olea, Olive

O. (Osmanthus) Americana, Wild Olive. Racemes shorter than the leaves; flowers polygamous or dinecious; drupe ovoid, deep purple. Light soil near the coast, or planted. Spring.

O. fragrans, Tea Olive. A shrub with serrate leaves and flow ars in axillary corymbs. Cultivated.

2. Stamens included, - - - - - - - - - - 3

3. Corolla 4-parted, - - - - - - - - - -4

3. Coro.la 5-8 parted;-climbing or erect shrubs with fragrant white or yellow, rarely red flowers; calyx 5-8 lobed; corolla salvershaped; stamens 2, ovary 2-celled, each cell with one orule; fruit a double berry, 2-seeded. Cultivated. - Jasminum, Jasmine

J. Sambac, Arabian Jasmine. Flowers white; leaves opposite or ternate; plant climbing.

J. offinale (poeticum). Flowers white; leaves opposite, odd-pinnate; plant requires support.

J. Grandiflorum, Spanish Jasmine. Flowers white; leaves opposite, pinnate; piant drooping.

J. revolutum, Italian Jasmine. Flowers yellow; leaves alternate, odd-pinnate; plant drooping.

J. odoratissimum, Madeira Jasmine. Flowers yellow; leaves alternate, odd. pinnate; plant erect, somewhat drooping.

4. Corcila saiverform, tube longer than the lobes;-shrubs with the fragrant fowers in a terminal panicle or thyrse; calyx small; corCi.ja iliac or white, style 1, stigma 2-cleft; fruit a capsule. Cultivated.

S. vulgaris, with cordate-ovate leaves and fowers in a dense thyrse.

S. Persica, with lanceolate leaves, often pinnately cleft, and small panicled flowers.

4. Corvila funnelform, tube shorter than the lobes;-shrubs with flowers in termual panicles; calyx shurt or truncate; corolla white or 
greenish; stamens 2, partly included; styles thick; fruit a berrylike drupe. Cultivated. - - - - - - Ligustrum, Privel

L. Amurense, with small leaves, and L. Nepalense, with large leaves, are evergreens, planted in hedges.

4. Corolla rotate, tube very short, and long linear lobes;-shrubs or small trees with perfect or polygamous flowers in axillary, drooping panicles; calyx short and as the corolla 4-lobed; stamens 2; stigmas notched or 2-lobed; fruit a drupe, - Chionanthus, Fringe-tree

C. Virginica. Petals white, drupe deep purple or black. Cultivated.

142. Spigeliaceae (Loganiaceae), Logania Family.

Herbs, shrubs or vines with stipulate, simple, opposite or whorled leaves, and perfect, regular flowers in cymes or panicles; calyx and corolla 4-5 lobed; stamens 4-5, alternate with the corolla-lobes; ovary superior, 2-rarely 3-5 celled; ovules 1-2 or numerous in each cell; styles united or partially so; fruit capsular or baccate or drupaceous.

1. Shrubby vines;-leaves opposite, with minute caducous stipules; flowers dimorphous, solitary or few together, cymose; calyx and funnelform corolla 5-lobed; stamens 5 , ovary 2-celled; ovules numerous in each cell; stigmas 4; fruit a capsule, Gelsemium, Yellow Jessamine

G. sempervirens. A smooth evergreen vine with fragrant flowers. Thickets near water, and planted. Early Spring.

1. Herbs,

2. Calyx shorter than the urn-shaped corolla; lobes of corolla valvate, throat bearded;-leaves opposite and stipules small; flowers in cymes, white or purplish; calyx and corolla 5-lobed; stamens 5 ; ovary 2-celled with 2 styles united when young; capsule tipped with 2 curved horns. Low ground. Summer,

\section{Cynoctonum (Mitreola), Mitrewort}

C. Mitreola (M. petiolata), Deep green, with more or less petioled membranous leaves.

C. sessifolium. Pale green, with sessile leathery leaves, ovate to orbicular.

2. Calyx not shorter than the campanulate corolla; lobes of corolla imbricate, throat bearded;-branches 4-angled; leaves opposite and clustered below, narrow; calyx and corolla 4-5 lobed; stamens 4-5; ovary 2-celled with a very short style; capsule slightly 2-lobed. Dry soil. Summer. - _ - . - Polypremum

P. procumbens. Stems clustered, erect or prostrate; flowers very small, white.

\section{Gentianaceae, Gentian Family.}

Mostly herbs with simple, exstipulate leaves, partly sheathing, opposite, rarely alternate; flowers regular, cymose; calyx 4-12 parted; corolla 4-12 lobed; stamens alternate with the corolla-lobes and inserted on its tube; ovary su- 
perior, 1-celled, with numerous ovules; style mostly 1 , stigmas 1-2; capsule 1-or falsely $2-4$ celled.

1. Corolla-lobes imbricated; leaves reduced to scales;-slender herbs with the scales opposite or alternate, and the flowers in terminal racemes or panicles, or solitary; calyx-lobes $\mathbf{4 - k e e l e d ;}$ corolla deeply 4-parted, white or yellowish; stamens 4 , included; stigma 2-lobed. Wet pine-land.

\section{Bartosia}

B. verna. Corolla-lobes spatulate to obovate, white. Early Spring.

1. Corolla-lobes convolute; leaves present; -herbs with opposite or whorled leaves, sessile or clasping, rarely petioled; flowers solitary or in terminal cymes; caly $x$-lobes 4 , corolla-lobes $4-12$; stamens 4-12, adnate to the rotate corolla; anthers mostly coiled; ovary 1-celled with intruding placentae; styles united, stigmas

2. Wet pine-land. Spring and Summer., Sabbatia, American Cenlaury

a. Corolla-lobes $4-7$.

a. Corolla-lobes 8-12;-leaves linear to lanceolate; corolla rosepurple to white, with yellow eye, - - - S. dodecandra (chloroides)

b. Branches of the stem opposite, - - - - - - - - c

b. Branches of the stem alternate, - - - - - - - - d

c. Stem round; calyx-lobes shorter than the tube; corolla white,

S. macrophylla

c. Stem 4-angled or winged; calyx-lobes linear, longer than the tube; corolla white.

Calyz-lobes longer than the tube, - - _ - S. lanceolata

Calyx-lobes about thrice as long as the tube, - - - S. paniculata

d. Calyx-lobes foliaceous; linear to oblanceolate, usually longer than the corolla;-corolla rose or nearly white. S. calycina (calycosa)

d. Calyx-lobes very narrow to filiform, usually shorter than the corolla, e

e. Stigmas longer than the style, - - - - - - - - - f

e. Stigmas shorter than the style, - - - - - - - g

f. Calya-lobes less than one-half of the corolla-lobes; corolla white or cream-color,

S. Elliottii

t. Calyx-lobes nearly as long as the corolla-lobes; corolla pink or white,

g. Corolla lobes 1-2 cm. long, rose or magenta with yellow eye,

S. campanulata (gracilis)

g. Corolla-lobes $2-3 \mathrm{~cm}$. long, pink or white, sometimes striped.

S. grandiflora (gracilis var. grandiflora)

144. Menyanthaceae, Buckbean Family.

Aquatic herbs with alternate or basal leaves, simple or 3-foliate; flowers solitary or clustered: calyx 5-lobed; corolla rotate or funnel-form; stamens 5 , adnate to the corolla-tube, with versatile anthers; ovary 1 -celled, style 1 , short, with 2 stigmas; fruit a capsule.

Stems foating or creeping; leaves basal on long petioles; flower-clusters on a stalk, sometimes with tubers; corolla rotate, white or yellow.

Nymphoides (Limnanthemum)

N. aquaticum (L. trachyspermum), Floaling Hearl. Leaves large, suborbicular to 
reniform, dotted and pitted beneath; tubers usually absent; flowers small, white. Ponds. Spring and Summer.

\section{Apocynaceae, Dogbane Family.}

Herbs or shrubs, sometimes vines or trees, mostly with latex, with opposite or alternate exstipulate leaves; regular 5 -parted flowers in cymes and panicles or solitary or few together; stamens distinct, inserted on the corolla-tube and alternate with its lobes; carpels 2 , distinct or united, superior; styles united, fruit consisting of 2 follicles or drupes; seed often with an appendage; mostly evergreens.

1. Anthers unappendaged,

1. Anthers appendaged at the base,

2. Shrubs or trees with alternate leaves; flowers solitary or few together; corolla funnelform with inequilateral lobes; fruit a drupe from 2 carpels. Summer. Cultivated.

- Theretia

T. neriifolia, Yellow Oleander. Branching shrub with many narrow, sessile leaves and yellow or salmon-colored flowers.

2. Shrubby climbers; leaves opposite, short-stalked; peduncles long; calyx-lobes reflexed; corolla white, the tube contracted below the middle, with screw-shaped border; fragrant. Early Summer.

Cultivated. - Trachelospermum (Rhyncospermum) jasminoiles, Confederate Jessamine or Star-jessamine

2. Herbs, sometimes partly shrubby,

3. Leaves alternate;-flowers in terminal cymes; corolla salverform; stamens included,

A. ciliata. Stem and branches pubescent; leaves linear; calyx-lobes acute; corolla glabrous. Dry pine-land. Spring and Summer.

3. Leaves opposite, - - - - - - - - - - - 4

4. Corolla funnelform, anthers with a foliaceous connective, stigma smooth, carpels 6-8 ovuled;--stems trailing; flowers mostly solitary in the axils, violet, purple or white. Summer. Cultivated. - - - - - - - - - Vinca, Periwinkle

V. minor. Procumbent; leaves elliptic-lanceolate, not ciliate.

V. major. Decumbent; leaves ovate; ciliate at the edges.

4. Corolla salverform, anthers with an inconspicuous connective, stigma pubescent, carpels many-ovuled;-partly shrubby, erect stems; flowers often 2 together. Summer. Cultivated. Ammocallis, Periwinkle

A. (Vinca) rosea. Leaves rather fleshy; corolla white or pink.

5. Shrubs with opposite leaves; flowers white in 1-8 flowered clusters; corolla salverform, the petals crimped. The double variety is mostly cultivated. - - Tabernæmontana coronaria, Crape jasmine

5. Shrubs with opposite leaves; flowers large, white, in two's; corolla salverform with screw-shaped border. Cultivated. Stemmadenia bella

5. Shrubs or trees with leaves opposite or in 3's; corolla salverform; flowers in terminal compound cymes. Cultivated. - Nerium, Oleander

N. Oleander. Shrub with numerous narrow leaves, and roseate, pink or white flowers, of which several single and double varieties are planted. 
5. Shrubs with leaves opposite or in 4's; corolla funnel-bellform. flowers solitary or few together. Cultivated.

Bushy or climbing shrubs with yellow flowers (A. neriifolia, Hendersonii, Williamsii), rarely with purple flowers (Blanchetti).

\section{Asclepiadaceae, Milkweed Fumily.}

Herbs, vines or shrubs, mostly with milky sap; leaves opposite, alternate or whorled, without stipules; flowers perfect, mostly umbellate, 5-parted; calyx inferior, its tube short or absent; corolla-lobes usually reflexed; between the corolla and the stamens is the CROWN, adnate to the one or the other, or to both; filaments usually monadelphous or distinct, the anthers converging around the stigma; anther-cells with a scarious membrane or unappendaged; pollen coherent into waxy or granular, pear-shaped masses, POLLINIA, connected with the processes of the stigma; ovaries 2 ; styles 2 , with a common fleshy stigma; fruit of 2 several-seeded follicles; seeds compressed, usually with a long coma.

1. Crown annular, saucer-or cup-shaped; mostly twiners,

\section{Vincetoxicum (Gonolobus)}

V. (G) suberosum. Stem slender, twining, with ovate-oislong, thickish leaves, and the flowers in racemes; corolla brown-purple; crown an annular disis undulately 5- or 10-crenate, adnate to the corolla; stigma depressed; po!linia pyriform, rounded at the base, with broad winged caudicles; follicles 3-5 angled. Riverbanks. Spring and Summer.

V. (G.) Floridanum. Stem slender, hirsute, with ovate, tapering leaves; ra. cemes about as long as the petioles; corolla dull-greenish or purplish; crown red-purple, saucer-shaped, with 5 broad undulations, each bidentate at the apex, and a smaller tooth on each side in the midule; pollmia obions with broad caudicles. Sandy soil. Summer.

V. gonocarpos (G. macrophyllus). Stem slender, high-climbing; leaves broadly ovate, cordate; cymes few-flowered with fleshy peduncles; corolla dullgreenish; crown a low 10-undulate fleshy ring; stigma depressed; pollinia pear-shaped with broad caudicles. River-hammuck. Early Summer.

V. hirsutum (G. hirsutus). Stem twining, thinly hirsute; leaves ovate, cordat:; acuminate; umbeis 6-S fowered; corolla brown-purple to greenish yeliow; crown cup-shaped. fleshy; pu...inia oblong. Thickuts Summer.

1. Crown of 5 depressed spreading segments; evergreen woudy vine, - Hoya

H. camosa, Hax-plant. Leaves oval-ublung. fleshy; fiuwers in dense umbels. pink, war-like. Cultivated.

1. Crown 5-lobed; slender twining vines, - _ _ _ _ - Seutera

S. palustris (maritima). Shrubby at the base; stem filiturn with feshy, linear drwoprag leaves; lung-peduncied umbels, several flowerel; curulla purplish or greensh. with cruwn attached to the very short cuiumn; pullinta oblong on stout caudicles. Salt marshes. Summer.

1. Parts of erown booded. 
2. Hoods without horn-like processes,

2. Hoods with horn-like processes,

a. Flowers orange to yellow,

a. Flowers whitish, greenish or purplish,

b. Stem hirsute, erect or ascending, branched; leaves alternate; umbels numerous and many-flowered;-leaves lanceolate-oblong to linear; corolla-lobes narrowly oblong, greenish or reddish orange; crown with linear hoods, orange, rarely yellow. Dry fields. Summer and Fall.

\section{A. tuberosa, Butterfly-zeed, Pleurisy-roos}

b. Stem smooth, tall, mostly simple; leaves distant; umbels few and few-flowered;-leaves lanceolate to oblong-linear; corolla-lobes oblong, reddish purple; crown with oblong hoods, orange. Swampy ground. Summer. - A. lanceolata (paupercula)

c. Leaves oblong or elliptic, sessile, clasping;-stem smooth; leaves opposite; umbels loosely many-flowered; corolla-lobes greenish or greenish purple; crown with slightly gibbous hoods, flesh-colored or reddish. Sandy soil. Spring and Summer. - - - - - - A. amplexicaulis (obtusifolia)

c. Leaves ovate to lanceolate, narrowed into a petiole, - _ - _ d

c. Leaves linear to filiform, - - - - - - - - - e

d. Stem hirsute-pubescent, branched, and very leafy at the top; umbels numerous and many-flowered, corymbose; corolla small, rose-purple to white, crown flesh-colored. Moist fields. Summer and Fall. - - - - - - - A. pulchra

d. Stem woody at the base, smooth, chiefly simple, slender; umbels solitary or corymbose; corolla small, white tipped with pink outside, crown white. Muddy ground. Spring and Summer.

d. Stem smooth, purplish; leaves in 3-7 pairs, the middle pairs sometimes in whorls of 4 ; flowers in crowded globose umbels; corolla whitish, crown purple. Dry shaded ground. Spring and Summer.

A. variegata

d. Stem stout, tomentose, cinereous; leaves opposite, with broad midvein; umbels 2-6 in the upper axils; corolla yeliowish green, crown purplish. Dry ground. Summer. - - - A. obovata

e. Leaves opposite;-stem glabrous, erect, slender; umbels 2-6, few-flowered; corolla purplish outside, ash-colored within; hoods of the crown whitish and purple-keeled. Dry pineland. Summer. - - - - - - - - A. cinerea

e. Leaves in whorls of $3-6$, or scattered;-stem glabrous or pubescent in lines, mostly simple; umbels loosely flowered; corolla greenish white; crown white to yellowish. In sterile soil. Spring to Fall.

3. Corolla oblong campanulate, lobes erect;-crown of $\mathbf{5}$ incurved pitcher-shaped bodies with involute ventral margins, remote from the anthers at the base of the long slender column. - - Podostigma

P. pedicellata (pubescens). Stem erect, rarely branched; leaves opposite, linear, pubescent; umbels several-flowered; corolla greenish-yellow, fragrant. Pine-barrens. Summer and Fall.

3. Corolla rotate, lobes spreading or reflexed;-hoods involute-concave, 
slightly pendulous at the base, adnate to the upper fart of the short colums.

A. Floridana (longifolia). Stem with linear leaves and $2-3$ or mire many-t?uw ered umbels; corchlla duil-purg!e ouisule; crown nurpilsh. adnate th the up. per fart of the column. rising to ahout the middie of the anthers: antherwings angled at the middle; fuldicles fusuform. Wet pine-land. Synng and Summer.

\section{Dichondraceae, Dichondra Family.}

Herbs with creeping stems and alternate leaves; flowers pedicelled, solitary in the axils; calyx 5-lobed; corolla 5lobed, rotate to campanulate; stamens 5 shorter than the corolla; ovaries 2 , pubescent; styles 2 , distinct; fruit consisting of 2 utricle-like capsules.

Stems branched, often matted; flowers erect.

- Dichoodra

D. Carolinensis. Leaves reniform or suborbicular, cordate, on long petioles; calyx silky; corolia small, greenish-white. Low grounds. Spring to Fall.

\section{Convolvulaceae, Morning-glory Family.}

Mostly prostrate or twining herbs with alternate, exstipulate leaves, and perfect regular flowers, solitary or in cymes; sepals 5, more or less united; corolla 5-lobed, angled or-plaited; stamens 5, partially adnate to the corollalobes and alternate with them; ovary free, $2-5$ celled, seated in a fleshy disk; styles 1 or 2 ; stigma sometimes 2-lobed; fruit a capsule, $2-4$ celled, or 1 - or 5-celled.

1. Styles 2-3, distinct or nearly so, - - - - - - - - - 2

1. Styles united into one, - - - - - - - - - - 3

2. Styles 2, distinct, each 2-cleft;-herbs with small flowers, solitary in the axils, or in terminal racemes or panicles; corolla white, pink or blue. funnelform, campanulate or rotate; stamens 5, included; ovary 2-celled.

E. sericeus. Linear, sessile leaves on slender zigzag branches; corolla rotate. Damp soil. Summer and Fall.

2. Styles 2. distinct or united below, entire;-prostrate or twining herbs with 1-5 flowers on axillary peduncles; corolla white, pink, purple or yellow. campanulate; stamens 5, included; ovary 2-celled.

Stylisma

S. humistrata. Sepals glabrous or nearly so; corolla white or pinkish. In sandy soil. Summer and Fall.

S. aquatica. Sepals silky-tomentose; corolla rose-purple. Around pine-land ponds. Sumamer and Pall.

3. Corolla salverform; stamens and style exserted:-twining vines with fowers in axillary cymes, or sulitary; corolla-limb shorter than the narrowly funoelform tube, 5-lubed; ovary 2-celied or falsely 
4-celled. Summer and Fall.

Q. (Ipomca) Quamoclit, Cypress-vine. Leaves pinnately parted, segments linear; corolla scarlet. Cultivated and escaped.

Q. (Ipomca) coccinea, Red Morning-glory. Leaves entire; carolla scarlet or orange-tinged. Cultivated and escaped.

3. Corolla funnelform or bell-shaped; stamens and style included, - _ $\quad 4$

4. Ovary 1-2 celled; leaves hastate or cordate;-trailing or twining vines, or erect herbs or shrubs, with flowers solitary or clustered in the axils; calyx naked or bracted; corolla white, pink or purple.

Convolvulus, Bind-weed

C. sepium (Calystegia sepia). Stem twining; leaves broadly sagittate; bracts of calyx ovate or oblong, keeled on the back; corolla white or rose. Waste places. Late Summer.

4. Ovary 3 or 5-celled; leaves entire, angled or lobed;-climbing or trailing herbs, with flowers solitary or in cymes; corolla white, blue, purple, etc. Cultivated. - - - - Pharbitis, Morning-glory

4. Ovary 2 or 4 celled; leaves entire, angled or lobed;-mainly climbing or trailing herbs, with flowers solitary or in cymes; corollalimb usually spreading. Summer and Fall. - Ipomcea, Morning-glory
a. Stems creeping, on the beach,
a. Stems twining or trailing, on sandy soil, .
b. Leaves ovate to oblong, later fiddle-shaped or lobed; corolla white with a yellow throat; seeds woolly. - I. (Batatas) littoralis

b. Leaves suborbicular; peduncle 1-several flowered; corolla purple, limb undulate; seeds pubescent. _ _ _ - - I. Pes-Caprae

c. Leaves palmately 7-parted;-stem twining, branching, hairy; corolla white with a purple throat; seeds smooth. Near the coast. - - - - - - - - - I. dissecta (sinuata)

c. Leaves entire or 3-lobed, - _ - - - - _ - - d

d. Leaves ovate to fiddle-shaped, cordate; peduncles 1-5 flowered; corolla white or pinkish, lavender inside; seeds woolly on the angles. Dry or damp soil. - - - - - - I. pandurata

d. Leaves hastate to sagittate, segments linear; peduncles usually 1-flowered; corolla purple, seeds villous. Sandy soil.

\section{I. speciosa (sagittata)}

d. Leaves ovate, entire or deeply 3-lobed, cordate; peduncles 1-3 flowered; corolla pink or purple, tube often whitish; seeds smooth. Sandy soil. - - - - I. Caroliniana (commutata)

The I. (Batatas) edulis, Sweet potato, with 3-5 lobed or angled leaves, and peduncles with 3-5 purple flowers, is cultivated for its tubers.

\section{Cuscutaceae, Dodder Family.}

Herbaceous twining parasites with long filiform stems, and minute alternate scales instead of leaves; flowers small, white, in cymes; sepals $4-5$, distinct or united; petals $4-5$, partly united, with or without scales; stamens 4-5, adnate to the corolla; ovary superior, 2 -celled; ovules 2 in each cell; styles 2, mostly distinct; fruit a capsule. "The plant 
germinates in the ground and soon decays at the root, after attaching itself to the host-plant by suckers.'

1. Flowers pedicelled.

Cuscuta, Love-rine

C. arvensis. Filiform, pale yellow at first, deeper yellow later; flowers 5-parted in rather loose clusters, corolla-lobes acute; scales as long as the corolla-tube, fnnged all around with short processes. Summer.

C. Gronovii. Slender, yellowish, becoming orange; flowers 5-parted in dense clusters, corolla-lobes obtuse; scales as long as the corolla-tube, sparingly fringed with stoutish processes. Summer and Fall.

\section{Hydroleaceae, Waterleaf Fomily.}

Herbs, sometimes shrubby, with alternate or opposite leaves and perfect flowers in cymes or scorpioid racemes; calyx and corolla 5-lobed; stamens 5, adnate to the corolla and alternate with its lobes; anthers versatile; ovary superior, 1-2 celled; styles often partly united; fruit a capsule.

Leaves altemate, flowers in cymes; calyz-lobes almost distinct; corro!:a rotate to campanulate; ovary 2-celled, styles distinct, Nama (Hydrolea)

N. corymbosum (Hydrolea corymbosa). Not spiny; leaves almost sessile; flowers in corymbose clusters; calyx bristly, corolla azure-blue with yellowish veins and five white spots near the base; stamens and style exserted. Ponds and swamps. Summer.

N. (H.) quadrivalvis. Spiny; leaves lanceolate, tapering into a petiole; flowers in small axillary clusters and solitary near the top of the stem; ca:yx some. what pubescent, corolla blue or lilac, stamens included. Mluddy places. Summer.

\section{Polemoniaceae, Phlox Family.}

Herbaceous or shrubby plants with alternate or opposite leaves and paniculate or corymbose flowers; sepals 5 , partially united; corolla 5-lobed, regular; stamens 5 , often unequal, adnate to the corolla-tube; ovary 3 -celled with united styles and 3 stigmas; fruit a 3 -celled capsule with one or more seeds in each cell.

1. Leaves often alternate, pinnataly parted ints linear b'jes; c srolla funnelform,

G. rubra (coronopifolia). Stem tall, leafy; flowers scariet or yellow, and red inside. in a raceme or narrow panicle; calyx campanulate. Sandy suil. Summer.

1. Leaves chiefly opposite, entire; corolia salverform, - - - - Phlox

P. Drummondii. Plant pulescent to villous; leaves mostly a!ternate, lanceislate to oblong; caiy $x$-lohes bristle-pointed, revolute; crsillia of all shades. white to purple, without or with a star. Cultuvated and escaped.

152. Solanaceae, Polato or Nightshade Family.

Herbs, shrubs or vines with alternate, mostly exstipulate leaves and usually 5-parted, rarely 4 or 6 parted flowers; 
calyx gamosepalous; stamens alternate with the lobes of the corolla and adnate to its tube; ovary superior, 2celled, sometimes 3-5 celled; styles united; fruit a berry or a capsule; seeds numerous.

1. Corolla campanulate; -herbs with simple leaves and axillary flowers, solitary or in clusters of $2-4$; calyx 5 -angled or 10 -ribbed; corolla yellowish or whitish, often with brownish or purplish center, with short and broad lobes. Sandy soil. Summer.

Physalis, Ground Cherry

P. pubescens. More or less villous and viscid; calyx-lobes narrow, twice its tube; corolla yellow with dark center; anthers purplish; berry yellow or greenish.

P. arenicola. Sparingly hairy; calyz-lobes triangular-lanceolate, equal to its tube; corolla light-yellow; anthers yellow; berry light-yellow.

P. viscosa. Creeping, stellate-pubescent; calyx-lobes triangular; corolla greenish-yellow with darker center; anthers yellow; berry orange or yellow, viscid.

1. Corolla rotate, tube very short,

1. Corolla funnel-sr salverform,

2. Anthers converging or connate, their cells opening lengthwise and introrsely;--herbs with 1-2 pinnately divided leaves, and 5-6 parted flowers in lateral raceme-like cymes; calyx spreading; corolla yellowish, limb plaited; berry very pulpy, Lycopersicon, Tomato

L. esculentum. Coarse, strong-scented herb, often more than 6-parted. Cultivated.

2. Anthers connivent, their cells opening by slits;-herbs with the leaves flat, entire or repand, and 5-parted flowers, solitary in the axils or in small cymes; corolla usually white; anthers bluish; berry red, yellow or green, nodding.

C. baccatum. Shrubby, somewhat pubescent, widely branching; leaves ovate to ovate-lanceolate, truncate at the base; berry globose to elliptic, red. Hammocks.

The Red (Cayenne) Pepper is obtained from several varieties of Capsicum annuum; Green Pepper is the unripe state of the fruit.

2. Anthers converging or connate, their cells opening by terminal pores or slits;-herbs, vines or shrubs with entire or lobed leaves and 5-parted flowers; corolla-limb plaited. In sandy soil. The wild species bloom throughout the year. - - Solanum, Nightshade

a. Wild species:

S. nigrum, Black Nightshade. Herbs without prickles; flowers whitish, berries black.

S. Carolinensis, Horse-nettle. Perennial, prickly; flowers violet or white; berries yellow to orange-yellow.

S. Floridanum, Horse-nettle. Perennial, prickly; flowers violet; berries orange-red.

S. aculeatissimum. Annual, prickly; flowers white, berries yellow.

a. Cultivated species:

S. Jasminoides, Patoto-jessamine, with white and yellow or bluish flowers and red berries, -and S. azureum, Tomatillo, with blue flowers in large bunches and large scarlet berries, are ornamental vines. 
S. tuberosum, Pola! ). Heriss with ut prickles, leaves ofi-pinnate and intertupted. Cultivated for its tubers.

S. Melongena, Ess-fion. Percnnial, prickly; Anwers 6-9 parte1, corolla purplish, frutt large, glossy-nurple or white. Cu'tivated.

3. Corolla-limb plaited. somewhat irregular;-herts with entire leaves and lange flowers soittary in the axils; stamens 4 . didynamous. and a fifth sometimes smaller or olisulete. Cultivated in many varieties; the two principal species are: - _ _ . - Petunia

P. ayctaginiflora. Erect, branched; curulla white, its tube thrice longer than the calys.

P. violacea. Ascending; corolla violet-purple, its tube twice longer than the calyx.

3. Corolla limb regular.

4. Stamens exserted:-shrubs or woody vines, prickly, with axillary 5or 4-parted flowers, - - - - - Lycium, Matrimony-vine

L. Carolinianum. Stems erect, widely branched, with fleshy clustered leaves; flowers small, purple; berries red. Along the coast.

4. Stamens included,

5. Shrubby; calyx campanulate or tubular, short; fruit a berry;-ieaves entire; flowers axillary. clustered, 5-parted. Cultivated. - Cestrum

C. diurnum, Day Jessamine, with white, scented flowers.

C. nocturaum, Night-blouming Jessamine, with creamy-yellow, strongly scented flowers.

C. elegans, with rose-pink and carmine flowers, fragrant.

5. Herbaceous; calyx prismatic, long; fruit a prickly capsule;-leares toothed or angled; flowers axillary, solitary, 5-parted, corolla tube much longer than the calyx. Waste places. Summer.

Datura, Jimson Weed, Thorn-apple

D. Stramonium. Stem stout. green; foliage nearly smooth; corulla white.

D. Tatula. Stem stout, purple; foliage nearly smooth; corolla vilut or lavender.

Several species with simple or double flowers are cultivated in various colurs.

5. Herbaceous; calyx urn-shaped; truit a capsule usually splitting into 4 valves:-tall plants; leaves simple, entire or undulate; Awwers in terminal racemes. panticles or thyrses, 5-parted. Cuit. vated,

Nicotiana

N. alata (affinis). Leaves lance-oborate or ovate-clliptic, sussile or clasping. the upper ones small and narrow; flowers white, sometimes purpish outside, remote in a vingate raceme. open at night-fall and iragrant.

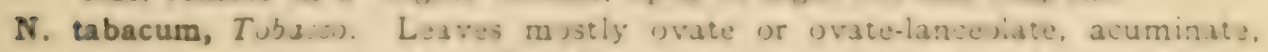
sessile or decurrent; fiowers re 1 or purplish in a large panicie, diurna!.

163. Borraginaceae, Borage Family.

Herbs or shrubby plants with bristly pubescent foliage; leaves simple, alternate, exstipulate; flowers 5-parted, in cymes or scorpioid racemes or spikes; sepals more or less united; corolla-lobes equal; stamens adnate to the corolla-tube, often with appendages; ovary superior, styles 
united, stigma simple or 2-lobed, and ovules solitary in each cavity.

Leaves sessile, prominently veined; corolla greenish-white or yellowish, tubular, longer than the calyx, naked in the throat but with the sinuses often inflexed; stamens included; ovary 4-parted; style exserted; fruit consisting of 4 or 1-2 white, shiny nutlets,

Onosmodium, False Cromwell

O. Virginianum. Leaves linear to oblong, 5-veined, numerous; scorpioid cymes or racemes terminal, bracted; calyx bristly; corolla yellowish-green, somewhat funnelform; nutlets pitted. Sand. Spring.

\section{Ehretiaceae, Ehretia Family.}

Shrubs or trees, sometimes herbs, with alternate, exstipulate, simple leaves, and perfect regular flowers in compound cymes; calyx 5- or fewer lobed; corolla 4-6 lobed; stamens 4-6 adnate to the corolla-tube; ovary 1-4 celled; styles 2 or 4 ; ovules 1 or 2 in each cell; fruit a drupe.

Shrubs or trees with scabrous or villous foliage; flower-clusters terminal; calyx 3-5 lobed, corolla campanulate to salverform, mostly 5lobed; stamens as many as the corolla-lobes; ovary 4-celled in a disk; styles 4 , unequally united by pairs; stigmas 4 ; drupe with accrescent calyx, - $\quad$ - _ - - - Cordia (Sebesten)

C. (S.) Sebestena, Geiger-tree. Evergreen shrub or small tree, with scabropubescent ovate leaves, and large corymbose clusters of orange or flamecolored flowers. Cultivated.

155. Heliotropiaceae, Heliotrope Family.

Mainly as preceding family, but style or stigma furnished with a glandular ring, surmounted by a 2-lobed appendage.

Heliotropium Curassavicum, Heliotrope. Prostrate fleshy herb; leaves alternate or nearly opposite, glaucous, lanceolate or linear; flowers small, white with yellow or bluish center; anthers acuminate; fruit consisting of four 1-seeded nutlets. Saline marshes. Summer. (Also found on the shore of Lake Monroe, near Enterprise). both.

Cultivated Heliotropes are H. Peruvianum and $\mathbf{H}$. corymbosum, or hybrids of

\section{Verbenaceae, Vervain Family.}

Herbs or shrubs with 4-angled stems and exstipulate, simple leaves, alternate, opposite or clustered; calyx often bracted, 4-5 cleft; corolla 4-5 lobed, sometimes bilabiate; stamens 2 or 4 , didynamous, adnate to the corolla-tube; ovary superior, $2-4$ celled, and 1 or 2 ovules in each cell; style 1 with an entire or 2- or 4-lobed stigma; fruit drupe- 
or berry-like, or dry and then separating into 2 or 4 nutlets.

1. Herbs, sometimes more or less shrubby, - - - - - - - 2

1. Shrubs or trees, - - - - - - - - - - 3

2. Stems erect; fruit of 4 nutlets:-leaves opposite; flowers in spikes; corolla-tube straight or curved, the $\operatorname{limb}$ regular, or more or less 2-lipped, the throat bearded; stamens 4 or 2 , included; ovary 4-celled with solitary ovules; stigma 2-lobed. Dry soil. Spring and Summer. - - - _ - - Verbena, Vervair

V. urticaefolia. Leaves lanceolate to ovate, crenate-serrate; flowers white in slender interrupted spikes.

v. Carolinensis. Leaves spatulate to oblong, doubly serrate; flowers pink or bluish in slender spikes, becoming interrupted.

v. angustifolia. Leaves linear to lanceolate, coarsely serrate; flowers blue or purple in linear spikes.

V. Lambertii (Aubletia). Leaves lanceolate, incised or lobed; stem branched at the base; flowers purple, lilac or white, showy. Dry soil and cultivated. Summer.

Several serbenas are cultivated with scarlet, purple, rose, lilac and white flowers either in spikes or panicles.

2. Stems procumbent or creeping; fruit of 2 nutlets;-leaves opposite or whorled; flowers in peduncled axillary spikes, subtended by a conspicuous bract; corolla 2-lipped, with 4 segments; stamens 4. included; ovary 2-celled with solitary ovules; stigma oblique, - Phyl

P. (Lippia) nodiflora. Leaves spatulate, serrate above the middle; flowers purple to white. Damp sandy soil. Spring to Pall.

3. Leaves $3-7$ digitately compound;-flowers in paniculate cymes; calyx with 5-3 lobes; corolla with spreading irregular limb; stamens

4. exserted; ovary 2 or 4 celled; fruit a drupe, Vitex, Chaste-tree

V. Agnus-Castus. Leaves $5-7$ foliate; corolla white, blue or purplish. Cultivated.

3. Leaves simple,

4. Flowers in dense peduncled spikes; fruit drupe-like of 2 nutlets; leaves opposite, toothed; corolla 4-5 lobed, more or less 2-lipped; stamens 4, included; ovary 2-celled, with solitary ovules. Sandy soil, escaped from cultivation.

L. Camara; opening yellow, but changing to orange or scarlet.

L. Sellowiana, Polecal-geranium; magenta or lilac.

4. Flowers in terminal or axillary racemes; fruit a drupe included in the calyx, of four nutlets;-leaves opposite or whorled; corolla funnelform or salverform, 5-lubed: stamens 4, didynamous. included; ovary imperfectly 8-celled; ovules 1.2 in each cell.

D. plumieri, Gublen Dewdrop. Flowers pale bluse or lilac, often with two purple streaks, in sacemes; drupes yellow; leaves opposite, elliptic, acute. entire or unequally serrate above the middle.

4. Flowers in terminal cymes; fruit a lobed or ribbed drupe;-calyx 5-lubed; corolla funnelfurm or salverform, 5-lobed; stamens adnate to above the mirdsle of the corcolla-tube. - - Clerodendron

C. Siphomanthus, Turk's Turbon. Fluwers in long trichotomous cymes, yel- 
lowish white; more conspicuous is the fruit, consisting of purple drupes; leaves in whorls of 3 's or 4's, long lanceolate.

C. Balfouri. A climber, with bright scarlet flowers enclosed in a bag-like calyx of pure white, in panicles.

C. falax. Leaves broad, evergreen, on long petioles; flowers scarlet.

4. Flowers in axillary cymes, sessile or peduncled, - - - - - $\quad 5$

5. Landplant; fruit a 4-seeded drupe;-leaves opposite, entire or toothed; corolla with 4 equal lobes; stamens 4 , often exserted; ovary imperfectly 2 -celled, with 2 ovules in each cell,

Callicarpa, French Mulberry

C. Americana. Bushy, scurfy-pubescent; leaves serrate; corolla bluish or pink; fruit violet or purple. Sandy soil and cult. Summer.

5. Evergreen maritime shrub; fruit a compressed oblique capsule;leaves opposite; calyx 5 -lobed, bracted; corolla 4-lobed; stamens 4 , adnate to the corolla-tube; ovary 1-celled, with a free central placenta, and 4 ovules; style 1 with 2 -cleft stigma,

Avicennia

A. nitida, Black Mangrove. Leaves dark-green above, paler beneath, shortpetioled; calyx and corolla pubescent; corolla white; fruit oblong or elliptic. Along the coast.

\section{Lamiaceae (Labiatae), Mint Family.}

Herbs and shrubs with 4-angled stems and opposite or whorled, exstipulate, simple leaves; flowers in axillary cymes; calyx regular or irregular, gamosepalous; corolla bilabiate or nearly regular, gamopetalous; stamens 4 and didynamous, or one pair abortive, adnate to the corolla-tube; ovary superior, deeply 4-lobed; style single, arising from between the lobes of the ovary; ovules solitary in each cell; fruit usually consisting of 4 nutlets included in the calyx.

1. Calyx 5- or 10-lobed, not 2-lipped, - - _ - _ - - -2

1. Calyx 2-lipped,

2. Corolla 2-lipped or very irregular,

2. Corolla nearly regular,

3. Corolla 2-lipped, lower lip 3-lobed,

3. Corolla irregular, lowest lobe saccate or boat-shaped,

4. Middle lobe much longer than the two lateral lobes, -

4. Middle lobe much broader than the lateral lobes, and often notched, $\quad 6$

4. Middle lobe nearly equal to the two lateral lobes, - - - - - 8

5. Stamens didynamous, exserted between the lobes of the upper lip of the corolla:-flowers in raceme-like panicles; calyx-tube 10ribbed, 5-lobed; upper lip of corolla short.

Teucrium, Germander

T. Nashii. Stem downy, grayish-white; leaves narrow-oblong to lanceolate; calyx prominently ribbed when mature; corolla pink. Near the coast. Spring and summer

T. Littorale. Stem downy, grayish-white; leaves narrow-oblong to lanceolate; calyx scarcely ribbed; corolla pale pink. Near the coast. Summer.

5. Stamens with anthers 2 , the other 2 rudimentary or wanting;-flow- 
ers in dense clusters: calyx-tube 15-ribbed. 5-lohed; upper lip of corolla narrow.

M. ffstulosa, Wibt Bergamol. Horse-mint. Stem stightly vilinus, purplespot. ted; leaves ovate to lanceolate, serrate; calyx-tuhe shightly curved. villous in the throat; corolla lilac; involucre purplish. High sandy ground. Summer and Fall.

M. punctata. Stem puhescent; leaves linear-oblong to lanceniate, serrate; calyx not bearded in the throat; corolla yeilowish, the lower lip dotte 1 with brown; involucre somewhat colored. Sandy soil. Summer and Fall.

6. Calyx-lobes 5 ,

6. Caly $x$-lobes 10; - woolly herbs with fowers in dense, axillary clusters: calyx-tube 5-10) ribbed, lobes equal or alturnately long and short; stamens 4, iocluded, - _ _ - - Marrubium, Hoarhound

M. vulgare. Leaves oval or ovate, crenate; bracts subulate with hooked ends; corolla small, white. Escaped from cultivation. Summer.

7. Calyx-lobes not spiny;-flowers in terminal spike-like racemes; calyx campanulate, more or less inflated, tube 5 -ribbed, lobes 5 unequal; stamens 4, anther-bearing, - _ _ _ - Physostegia

P. Virginiana. Stem erect or trailing; leaves linear to lanceolate, sessile; flowers in spike-like racemes; corolla bright pink, the lower lip denticulate, the upper 3-lobed. Low ground. Summer.

?Caly $\mathbf{x}$-lobes rigid or spiny;-flowers in clusters, the upper ones sometimes contiguous; calyx-tube 5-10 ribbed; lobes equal or nearly so; stamens 4.

S. Floridana, Hedge-nellle. More or less hirsute; leaves oblong to ovate, serrate or dentate, with petioles nearly as long as the blades on lower part of stem; corolla twice as long as the calyx, purple. Low sandy soil. Summer.

8. Anthers 2-celied, the cells diverging; prostrate herbs;-thowers few or many, or solitary in the axils; calyx-tube usually 13-ribbed; lobes 5, nearly equal, sometimes almost 2-lipped; corolla small or minute; stamens 4, - _ _ _ - _ - Micromeria

M. Brownei. Stems smooth or nearly so; leaves broadly-orate, undulate or crenulate; pedicel longer than the calyx; corolla purple. Riverbanks. Sum. mer.

8. Anthers 2-celled, the cells diverging; pubescent tall herbs;--ilowers in dense axillary whorls; calyx 10-ribbed, s-lobed, and awnipped; corolla-tube curved, dilated above; stamens 4. - - Leonotis

L. nepetaefolia. Suftly pubescent; leaves ovate, crenaie; corolla villous, scarlet or orange-yellow; upper lip as long as the tube and longer than the 3 cleft lower lip. Waste ground. Summer.

8. Anthers 2-celied, the cells separated; shrubby plants;-fiowers in dense, bracted, spike-like racemes or panicles; calyx delicatc, lu-ritbed, 5-lubed, silky: corolla longer than the ca!yx, upper lip erect; stamens 4, the outer 2 longer than the inner 2, and exserted.

P. rigidus (Satureia rigida). Stems with many spreading branches; leater small, opposite. numerous, rugid, lanceolate, sharply revolute. sessice, with clusters of smalier leaves in the axils; racemes sulghinguse or cyinitre; corilla light purpie. with darker blotches on the muldle lube of the luwer hip. municly pubescent. In sand and pine-land. Early Spring.

9. Lowest bibe of corjlla dropping, coniracicl at its base, the other 
four lobes flat, erect or spreading;-flowers in axillary, subglobose clusters, approximate or remote; calyx-lobes 5 , nearly equal; stamens 4, declined, - $\quad$ - $\quad$ - _ - Mesosphaerum (Hyptis)

M. spicatum (H. spicata) Pubescent; leaves petioled, deltoid-ovate, crenateserrate; flower-clusters nearly sessile; corolla much longer than the calyx. Sandy soil. Spring to Fall.

M. rugosum (H. radiata). Pubescent above; leaves decurrent on the petioles, ovate to linear-lanceolate, somewhat serrate; flower-heads dense, peduncled; calyx and corolla pubescent; corolla small, white dotted with purple. Damp soil. Summer and Fall.

9. Lowest lobe of corolla boat-shaped, longer than the obtusely 3-4 cleft upper part;-leaves large, bluntly serrate, marked with crimson, green and bronze. Cult. in many colors and kinds,

- Coleus

10. Anther-bearing stamens 4, long-exserted, partly coiled;-flowers in axillary cymes or solitary; calyx short with 5 teeth of which 2 are very short; corolla slender nearly equally 5-cleft, - - Trichostema

T. dichotomum. Nearly smooth branched stem; leaves lanceolate to oblong; short petioled; corolla blue, pink or white. Sandy soil. Fall.

10. Anther-bearing stamens 4, not long exserted, erect;-flowers in dense, remote or contiguous clusters; calyx-tube 10-ribbed, lobes 5 , nearly equal; corolla-tube shorter than the calyx; upper corolla-lobe somewhat larger than the rest.

Mentha

M. piperita, Peppermint. Stems smooth; leaves oblong, oval to ovate, sharply serrate, short-petioled; flowers in interrupted spike-like panicles; calyx smooth; corolla white, pale-purple or blue. Cultivated.

11. Calyx-lips entire, the upper one crested;-flowers in racemes or panicles; corolla 2-lipped, the upper lip arched, the lower lip with 2 small lateral lobes and a larger, spreading, middle lobe; stamens 4, upper pair with 2-celled, lower pair with 1-celled anthers, all ciliate, - - _ - - - Scutellaria, Skull-cap

S. lateriflora. Branching; leaves petioled, ovate-lanceolate, coarsely serrate; flowers small, blue, in axillary racemes, usually 1-sided. Riverswamps. Summer.

S. integrifolia. Simple, or branching above; leaves petioled, the lower ovate, coarsely toothed, the upper oblong to linear, entire; racemes or panicles few-or many-flowered; corolla blue or pale, pubescent. Dry soil. Summer.

S. Floridana. Nearly simple; leaves sessile, narrowly linear; racemes few-flowered; calyx densely punctate; corolla blue; anthers long-bearded, Swampy pine-land. Summer.

11. Calyx-lips lobed, both or only one, - - - - - - - -12

12. Stamens 4 only 2 fertile, or stamens 2, - - - - - $-\quad$ - 13

12. Stamens 4, all anther-bearing, anthers awnless;- herbs or shrubs with flowers in axillary clusters, sessile or peduncled; calyx-tube usually 13-ribbed; corolla 2-lipped, upper lip erect, entire or notched, lower lip 3-lobed, spreading. In sand. Summer,

Clinopodium (Calamintha), Basil

C. macrocalyx. Branching shrub; leaves broadly spatulate, contracted into a narrow base, punctate; corolla scarlet, upper lip notched. 
C. dentatum. Diffusely branched shrub, rusty-pubescent; leaves obovate, sessile; corolla white or purplish.

13. Upper corolla-lip not concave;-herbs, usually aromatic or pungent; leaves opposite; flowers in axillary clusters or solitary; calyxtuhe 13-ribbed with 5 nearly equal lobes, or 2-lipped; corolla 2-lipped, upper lip 1-2 lobed, lower lip 3-lobed, - - - Hedeoma

H. pulegioides, Pennyroyal, Stem erect, more or less branched; leaves elliptic to oblong: flowers few or solitary in the axils, peduncled; calyx 2-lipped; corolla blue, lips nearly equal. Dry soil (Crow's Bluff). Spring and Summer.

13. Upper corolla-lip concave;-plants with leafy or scape-like stems; leaves opposite or mainly basal; flowers in axillary clusters, disposed in spikes, racemes or panicles; calyx-tube ribbed; upper lip with 3, lower lip with 2 lobes; corolla 2-lipped, lower lip 3 lobed. longer than upper lip; anther-bearing stamens with a conspicuous connective at the apex. Sandy soil. Summer.

Salvia, Sage

S. azurea. Stems more or less branched; leaves oblong to linear, narrowed into short petioles; flower-clusters subtended by narrow bracts and disposed in panicles; calyx slightly pubescent; corolla blue or white, upper lip hearded on the back, middle lobe of lower lip much broader than long and deeply notched.

S. Iyrata. Pilose or hirsute; stems almost scape-like; leaves chiefly basal, spatulate, lyrate-pinnatifid; panicles much interrupted, the clusters few-flowered; pedicels long; calyx hirsute; corolla blue-purple, with the middle lobe of lower lip broader than long, notched. Spring.

S. coccinea. Stem simple or sparingly branched; leaves ovate, crenate-serrate; calyx minutely pubescent, upper lip reniform, lower lobes ovate; corolla scarlet, lower lip notched. Cultivated and escaped.

Many species are cultivated for their showy blue, white, red or yellow flowers; most common is S. spleadens with caly $x$ and corolla scarlet.

\section{Rhinanthaceae (Scrophulariaceae), Figwort Family.}

Chiefly herbs with round stems and exstipulate, simple leaves; flowers perfect; 4-5 sepals, more or less united; corolla bilabiate or only slightly irregular, $4-5$ lobed; stamens 4, didynamous and often 1 staminodium, or stamens 2 and 2 staminodia, all inserted on the corolla-tube; ovary superior, 2-carpeled, 1-celled with axile placentae; style simple or 2-cleft; fruit a 2-celled capsule.

1. Leaves alternate, or leaves opposite and corolla spurred, - _ - $\quad 2$

1. Leaves oppusite or whorled, and corolla not spurred, _ _ _ 3

2. Leaves alternate; - herbs with sessile leaves; fowers in terminal bracted racemes; calyx tubular, oblique; corolla bilabiate; stamens 4. didynamous, included, - $\quad$ - _ _ . - Schwalbea

S. Americama. Stem simple or sparingly branched; leaves lancerlate to oblong: flowers in a spiked raceme, yellowish purple. Low sandy ground. Early Summer.

2. Leaves alternate or opposite, corolla spurred;-berbs with narrow leaves; lowers in terminal spikes, racemes or panicles; calyx 
deeply 5-parted; corolla bilabiate, personate; stamens 4 , included.

In sand. Spring and Summer. - - - - Linaria, Toad-flax

L. Canadensis. Smooth, erect, slender, sometimes branched at the base; leaves linear; racemes usually several-flowered; corolla small, light-blue or white.

L. Floridana. Stem sparingly glandular-pubescent, simple or branched above and at the base; the lower leaves oblong, those on the stem linear; racemes loosely flowered; corolla blue; spur subulate.

3. Stamens 2, exserted; corolla rotate;-flowers solitary in the axils, or in racemes or panicles; calyx 4-5 parted; corolla 4-5 lobed.

In cultivated ground. Spring and Summer. - - Veronica, Speedwell

V. arvensis. Finely pubescent; leaves ovate; corolla pale blue.

V. peregrina. Smooth or glandular; leaves fleshy, oblanceolate, corolla white.

3. Stamens 2, included, with or without staminodia; corolla bilabiate, - - 4

3. Stamens 4 , with or without a staminodium, - $\quad$ - $\quad$ - $\quad$ - $\quad$ - 7

4. Calyx of 4 partially united sepals; corolla nearly regular;-small herbs with creeping stems and sessile, suborbicular leaves; flowers small, solitary in the axils; corolla obscurely 2-lipped; stamens 2.

M. orbiculatum. Stems tufted; corolla white or purplish. Muddy soil. Summer.

4. Calyx of 5 nearly distinct sepals,

5. Filaments elongated, slender; - herbs with mostly sessile leaves; flowers solitary in the axils on slender peduncles; corolla 2-lipped; stamens 2, staminodia 2. - - - Ilysanthes, False Pimpernel

I. refracta. Stems erect, tufted, wiry; leaves basal, spatulate; sepals linear; corolla pale blue or purplish. Damp ground. Summer.

5. Filaments short and stout, or almost wanting, - - _ - - - 6

6. Connective of the anthers dilated, cells transverse;-flowers solitary on axillary peduncles; calyx 5-parted, with 2 bractlets; rather succulent herbs, smooth or softly pubescent, - Gratiola, Hedge-hyssop

G. Virginiana. Pubescent above; peduncles about as long as the bracts; corolla with yellowish tube and whitish lobes. Muddy banks. Early Summer.

G. sphaerocarpa. Glabrous; peduncles rarely one-half of the bracts; corolla white. Low ground. Summer.

G. ramosa. Slightly pubescent, viscid; peduncles as long as the bracts or longer; corolla whitish. Wet soil. Summer.

6. Connective of the anthers not dilated, cells vertical;-flowers solitary, sessile or short-peduncled in the axils; calyx 5-parted with 2 bractlets; rigid herbs, rough-pubescent. Spring to Fall.

Sophronanthe (Gratiola)

S. hispida (G. subulata). Hispid, usually clustered; leaves linear; corolla salverform, about twice as long as the calyx, white or purplish. Low pinebarrens.

S. (G.) pilosa. Hirsute, simple or sparingly branched; leaves ovate to oblong; corolla tubular, scarcely longer than the calyx, white. Low ground.

7. Sterile stamen as long as the others, and more or less bearded;- - llowers in terminal racemes or panicles; calyx 5-parted; corolla 2 lipped,

P. multiflorus. Lower leaves spatulate or oblong, upper leaves fer, oblong- 
lanifolate. decurrent; co:o:la white, staminodium nearly smooth. Pineland. Spring to Summer.

P. Pentstemon (laevigatus). Lower leaves oblong or spatulate, upper leaves obluns-lanceulate, sessile; corolla purplish; staminodium densely bearded. Pincland. Spring and Summer.

7. Sterile stamen miaute or absent, - - - - - - - - 8

8. Calyx 5-toothed, - - - - - - - - - - - 9

8. Calys 5-parted. - - - - - - - - - - - 10

9. Corolla salverform;-flowers in elongated terminal spikes; caly: $\mathrm{x}$ tube 5-10 ribbed; corolla 5-lobed, tube curved. Pine-land.

Summer. - - - - - - - - Buchnera, Blue-hearls

B. elongata. Stem scabrous, sometimes branched above; corolla blue or white. its tube less than twice as long as the calyx; spikes loosely flowered.

B. Americana. Stem branched, hispid; corolla purple, its tube more than twice as long as the calyx; spikes more copiously flowered.

9. Corolla campanulate;-leaves narrow or scale-like; flowers solitary in the axils; corolla 5-lobed, somewhat 2-lipped, rose-purple, rarely white, - - - - - - - - - Gerardia

a. Perennial with rootstock. Low pine-land. Fall. - G. linifolia

a. Annuals, with fibrous roots, - - - - - - - - b

b. Leaves few or scaly. Low pine-land. Fall. - _ - G. aphylla

b. Leaves succulent, linear. Salt marshes. Summer. - G. maritima

b. Leaves all more or less linear, - _ _ _ _ _ - - c

c. Larger leaves with clusters of smaller ones in their axils; - - _ d

c. Larger leaves with few or no such clusters. Low ground. Fall.

d. Leaves opposite. Dry pine-land. Fall. - - - G. setacea

d. Leaves alternate, at least the upper ones, - - - - - e

e. Stem and leaves smooth. Sandy pine-barrens. Fall. - G. flifolia

e. Stem and leaves rough. Marshes near the coast. Summer and Fall.

G. fasciculata

9. Corolla bilabiate;-flowers mostly solitary in the axils; calyx-tube angled; corolla-tube with 2 ridges inside. Cultivated and in swamps. Summer and Fall. - _ - Mimulus, Monkey-fower

M. Jamesii. Plowers yellow. Only cultivated.

M. alatus. Flowers blue, violet and white; pedicels stout, $t$-winged; leaves petioled.

M. ringens. Flowers blue, violet and white; pedicels slender, 2 -winged above, leaves sessile.

10. Corolla inilated tubular, white, cream-colored, or red;-herbs with the fowers in dense terminal spike-like racemes; calyx 5-lobed, bracted; corolla dilated in the throat; staminodium small.

Chelone, Turlle-head

C. glabra. Leaves broadly linear to oblong, acuminate, petioled; corolla white or cream-colored, the lower lip bearded. Low ground (near Ustcen). Sunmer.

10. Coralla tubular-funnelform, bright-red;-cultivated shrubs with the flowers in louse racemes or single; calyx 5-parted, - Russelia

R. juncea (equisitiformis), Cural- or Funnain-planb. A shrisb with smouth. arching. rush-irke branches; leaves from small ovate or spatulate to minute-scaly; raceme very loosely flowered. 
R. sarmentosa (multiflora). Leaves opposite, ovate, acuminate, serrate-crenate; flowers verticillate in terminal racemes.

10. Corolla rotate, 4-cleft, white or yellow, or blue;-herbs, sometimes shrubby, with the flowers solitary in the axils; sepals 4-5, near1y distinct; stamens 4, nearly equal, - - _ _ - Scoparia

S. dulcis. Leaves ovate to oblong-oblanceolate; corolla small, white; its lobes oval or suborbicular. Sand. Summer.

10. Corolla rotate-campanulate, 5-lobed, yellow; stamens nearly equal;much branched herbs with pinnately parted leaves and the flowers solitary in the axils; calyx-lobes 5 , longer than its tube; style long-exserted.

- Afzelia (Seymeria)

A. (S.) pectinata. Stems viscid-pubescent, branched; calyx and corolla pubescent. Dry sandy soil. Summer and Fall.

10. Corolla campanulate, 5-cleft, yellow; stamens didynamous;-herbs with toothed or pinnatifid leaves; flowers in bracted racemes or panicles, - - - - - - Dasystoma, False Foxglove

D. pectinata. Leaves lanceolate to ovate, 1-2 pinnatifid, segments finely toothed or incised; calyx densely glandular-hirsute, the segments toothed or pinnatifid; corolla widely dilated. Sandy soil. Summer.

159. Acanthaceae, Acanthus Family.

Chiefly herbs with simple, exstipulate leaves and bracted flowers; calyx 5-parted; corolla 2-lipped or almost regularly 5-lobed; stamens 4 didynamous, or 2 with or without another pair of abortive stamens (RUELLIAS have sometimes 5 stamens); ovary free, 2-celled, with single style and 1-2 stigmas; fruit a 2-celled capsule, 4-several seeded.

1. Normal leaves only at the base of the stem, or crowded at the ends of the branches;-flowers in dense spikes; corolla more or less 2lipped, white or blue; stamens 2, - - - - Tubiflora (Elytraria)

T. Carolinensis (E. virgata). Stems scape-like, covered with alternate scales, the basal leaves oblong to spatulate, or linear; calyx-lobes bearded at the tips; corolla-lobes nearly equal, white. Riverbanks. Summer.

1. Normal leaves on the stem;-corolla funnel- or salverform, lobes 5 , somewhat unequal; stamens 4 or 5 , - - - - -

2. Calyx-lobes bristle-like; anthers pointed at the base; ovules 2 in each cell;-leaves opposite; flowers solitary or clustered in the axils; corolla-tube slightly curved, limb somewhat 2-lipped, - Calophanes

C. humistrata. Leaves few, oblong, with petioles shorter than the blades; calyx puberulent; corolla white. Low pine-land. Spring.

C. oblongifolia. Leaves oblong or the lower obovate, sessile or short-petioled, calyx hirsute; corolla blue with purple spots. Sandy pine-land. Spring to Fall.

2. Calyx-lobes linear or lanceolate; anthers not mucronate; ovules $3-10$ in each cell;-leaves opposite; flowers solitary or clustered in the axils or in terminal cymes or panicles; corolla-lobes somewhat unequal. Spring and Summer. 
R. humilis. Stems very short; leaves few, spatulate to oval, sessile; calys bristly, with linear lobes; corolla blue to white with much dilated throat. Sandy soil.

R. strepens. Stems erect, simple or branched; leaves ovate to oblong, petioled; calyx bristly; corolla blue-purple or nearly white. Dry soil.

R. ciliosa. Stems erect, more or less branched; leaves oval to oblonz, ciliate. sessile; calyx bristly, corolla blue. Dry ground.

Several Ruellias are cultivated as potplants; the flowers are carmin. red or rose, blue or purple. white veined with lilac; some have the lower surface of the leaf purplish, as $\mathbf{R}$. devosiana and $\mathbf{R}$. makoyana.

Fittonia is a genus, cultivated for the large heart-shaped leaves with brilliant venation: F. Verschaffeltii has red veins, F. argyroneura has white veins.

Other geners in outdoor's cultivation are:

a. Thunbergia, mostly climbers with large 2-bracted flowers, as the blue $\mathbf{T}$. laurifolia and its varieties; $T$. alata with a buff or cream-colored corolla and dark-purple center; white, orange or jellow varieties. T. (Meyenia) erecta, an erect shrub, the corolla with purplish border and yellowish throat; white and violet and blue varieties.

b. Eranthemum. Shrubby plants with white, lilac or red flowers.

c. Daedalacanthus nervosus (Eranthemum pulchellum) with dark blue flowers in axillary spikes; blooms here in Winter.

d. Jacobinia. Shrubs or herbs with narrow-tubular red, orange or yellow flowers and opposite, entire leaves; calyx deeply 5-parted, corolla more or less 2-lipped. stamens 2 and 2 small staminodia.-J. coccinea, a shrub of about $2 \mathrm{~m}$. high, has crimson flowers in dense terminal spikes blooming in late Summer and $\mathrm{Fall}$.

e. Justicia is a genus closely allied to the preceding; it contains chiefly herbs with the red, pink or white flowers in bracted fascicles or heads; they are chiefly potplants.

f. Strobilanthes, erect half-shrubby plants with funncl-shaped flowers. The two chiefly planted are:

S. isophyllus, a bushy shrub with narrow-lanceolate lesves and narrow light blue flowers in early Spring.

S. avisophyllus with broad-lanceolate leaves and wile purplish blue flowers during Spring and Summer.

\section{Pinguiculaceae (Lentibulariaceae), Bladderwort Family.}

Scapose or caulescent herbs growing in water or wet places; leaves submerged and dissected, often bearing bladders,-or aerial, basal and entire,-or leaves wanting; flowers perfect, irregrular; calyx of 2 or 5 sepals; corolla 2-lipped, saccate or spurred; stamens 2, included, filaments twisted; ovary free, 1-celled, with numerous ovules; style short with 2-lipped stigma, the lower lip covering the anthers; fruit a capsule.

1. Sepais 5; coro!la-tube not closed by the palate:-scapose herbs in wet soll; leaves entre. forming a rosette at the base; suapes clustere 1. 1-tlowered; sepals more or less united; corolla raore or liss 2- 
lipped, spurred. Spring. - - - - Pinguicula, Butterwort

P. pumila, Valentine flower. Scapes not villous at the base; corolla light violet to white; spur longer than the sac-like base of the corolla, awl-shaped.

P. elatior. Scapes villous at the base; corolla purple to white; spur shorter than the sac-like base of the corolla, obtuse.

P. lutea. Scapes pubescent; corolla golden yellow; spur awl-shaped.

1. Sepals 2; corolla-tube closed by the palate;-aquatic or terrestrial scapose herbs with no stems or with stems creeping in wet soil, or more or less floating in the water; leaves dissected, and bladder-bearing or almost absent; flowers solitary or racemose; sepals slightly united; corolla 2-lipped and spurred. Spring to Fall.

Utricularia, Bladderwort

a. Stems more or less floating with solitary scapes arising from the nodes.

U. purpurea. Leaves none; racemes $1-4$ flowered; flowers violetpurple. Ponds.

U. inflata. Leaves dissected; each scape with a whorl of 6-9 inflated bracts; racemes 5-12 flowered; flowers yellow. Ponds.

U. radiata (inflata var. minor). Whorl of 4-6 inflated bracts; racemes

1-3 flowered.

b. Stems converging towards the base of the scape or scapes.

U. fibrosa. Leaves numerous, dissected; racemes 2-5 flowered; flowers yellow, spur about as long as the upper lip of the corolla.

c. Minute herbs; scapes solitary, rooting in the mud.

U. cornuta. Racemes spike-like, $2-8$ flowered; pedicels as long as the: calyx; corolla yellow. In sphagnous places. Summer.

ठ. subulata. Racemes 1-9 flowered; pedicels much longer than the calyx; corolla yellow. Wet pine-land. Spring.

\section{Orobranchaceae, Broom-rape Family.}

Parasitic herbs on the roots of other plants; leaves scale-like; flowers mainly perfect; calyx of 4-5 united sepals; corolla with bilabiate or irregular border, sometimes withering; stamens 4 didynamous, adnate to the corolla; ovary superior, 1-celled, with 2 or 4 placentae; style 1, stigmas 1-2; fruit a capsule.

Stems fleshy, and with the leaf-scales and flowers pale-yellow or brownish; flowers perfct in terminal bracted spikes; calyx with 2 bractlets, split on the lower side, 3-4 toothed on the upper; corollatube curved, border 2-lipped; stamens slightly didynamous, a staminodium sometimes present; ovary with 4 placentae.

Conopholis, Squaw-root

C. Americana. Stems clustered; calyx longer than the bracts; corolla longer than the calyx. Spring and Summer.

\section{Bignoniaceae, Trumpet-creeper Family.}

Trees, shrubs erect or climbing, sometimes herbs, with exstipulate, chiefly opposite leaves, and showy monopetalous, irregular flowers; calyx 2-lipped, 5-lobed or truncate; corolla 2-lipped or 5-lobed, tubular or campanulate; stamens 
5 of which 1-3 may be staminodia, or 4 didynamous stamens, inserted on the corolla; ovary superior, 1-2 celled, 2-carpeled, with parietal placentae, many-ovuled; style 1 with mostly 2 stigmas; fruit a leathery or woody capsule, 2-valved, 2- or 4-celled and many-seeded.

1. Trees with simple leaves;-leaves deciduous, alternate, opposite or whorled, long-petioled, lange; flowers in terminal panicles; caly $x$ and corolla 2-lipped, fertile stamens 2 , with 3 or less staminodia; capsule long, nearly round; seeds in $2-4$ rows, flat, with the menbranous testa extended into fimbriate wings. Cultivated. Spring.

C. Bignonioides. Panicles many-flowered; corolla white, with two rows of yellow spots in the tube and purple spots on the lower lip.

C. speciosa. Tree becoming twice as tall, with thick scaly bark; panicles fewflowered, lax; corolla as in preceding, generally less conspicuously spotted.

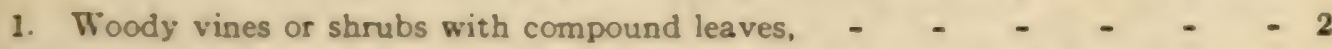

2. Calyx cup-shaped, truncate or slightly 5-toothed; capsule flattened parallel with its partition;-evergreen woody climbers with 2-3 foliate leaves, the terminal leaflet often represented by a tendril; corolla more or less 2-lipped; fertile stamens 4 and 1 sterile; capsule long and narrow, - - - Bignonia, Trumpel-fiower

B. crucigera (capreolata). Leaflets 2 and a forking tendril between; flowers in axillary clusters, red outside, yellow inside. Thickets and high climbing on trees. Spring.

B. venusta. Leaves opposite, leaflets 2 , tendril long, divided into three parts at the end; flowers in thick drooping clusters, bright orange-red. Cultivated on trellis. Winter.

Other cultivated species are B. alba with pure white flowers; B. speciosa with lange glossy leaves and purplish flowers; B. Tweedians with small leaves and bright yellow flowers.

2. Calyx tubular-campanulate with 5 nearly equal lobes; capsule flattened at right angles to its partition,

3. Evergreen climbers; leaves odd-pinnate; flowers in clusters or panicles; corolla tubular-funnelform; ovules in several rows in each cell of the ovary.

C. (Tecoma) radicans, Trumpel-creeper. A vine, climbing by aerial rootlets; leaflets 7-13, coarsely serrate; corymbs few-flowered; corolla red, scarlet or orange outside, yellow inside. Woods. Spring.

Cultivated species are: T. capensis with clusters of bright red flowers; T. jasminoides with flowers white and pink center; T. rosen with purplish-pink flowers.

3. Erect, evergreen shrubs;-leaves odd-pinnate; flowers in terminal racemes or panicles; corolla funnelform; ovules in two rows in each cell of the ovary: capsule slender with leathery valves, - _ _ _ Stenolobium

S. (Tecoma) stans, Yellow Elder. A tall shrub; leaflets 7-9. sharply serrate; racemes many-flowered; corolla yellow. Cultivated. Pall.

The variety sambucifolia begins to bloom in early Spring.

A cultivated shrub or small tree, cut back by frost but recovering, is Jacaranda ovalifolia (mimosactolia); the opposite or distant leaves are decompound with 16 or zore pairs of pinnac, each pinna with 14-24 pairs of leaflets; the blue Bowers in loose 
pyramidal panicles have a long, bent, swelling tube and 2-lipped border; stamens 4, didynamous, with 1 staminodium about as long as the stamens.

\section{Plantaginaceae, Plantain Family.}

Chiefly acaulescent herbs with basal ribbed leaves and small, whitish flowers in long or short spikes at the top of a naked scape; calyx of 4 slightly united sepals; corolla 4-lobed, and like the calyx scarious or membranous; stamens 2 or 4 with versatile anthers; ovary superior, style and stigma single; fruit a pyxis, 1-many seeded. Annual or biennial herbs.

Plantago, Plantain.

P. heterophylla. Leaves linear to filiform; stamens 2;-spikes slender, loosely. flowered; flowers diocious or polygamous; calyz-lobes not longer than the bracts; seeds 10-30, dark-red.

P. Virginica. Leaves broad, spatulate to elliptic; stamens 4 ;--spikes dense; flowers polygamous; calyx-lobes ionger than the bracts; seeds $2-4$, golden-yellow.

\section{Loranthaceae, Mistletoe Family.}

Green parasitic shrubs, feeding on the sap of woody plants by means of haustoria; leaves opposite; flowers regular; calyx truncate or lobed; corolla of $2-6$ more or less united petals; stamens $2-6$; ovary 1 -celled with a solitary ovule; pistil 1; fruit a berry.

Leaves leathery, persistent; flowers very small, diœcious, in short-jointed spikes; the sterile ones with a $3-$, rarely $2-5$ lobed corolla and 1 stamen at the base of each lobe; the fertile flowers with similar corolla and inferior ovary; berry subglobose, - Phoradendron, Mistletoe

P. fiavescens. Green or yellowish, growing in bunches on the limbs of deciduous-leaved trees; leaves fleshy, spatulate to oblong, entire, short-petioled; berry white, with glutinous pulp and a flat oblong seed. Spring.

165. Rubiaceae, Madder Family.

Herbs, shrubs and trees with simple leaves, which are opposite and united by interpetiolar stipules, or whorled; flowers regular, perfect or polygamous, in cymes, panicles or heads; calyx 3-6 lobed or toothed, or truncate; corolla of 3-6 more or less united petals; stamens distinct or united, alternate with the corolla-lobes and of the same number; ovary more or less adnate to the calyx-tube, 2-5 celled with 1-many ovules in each cell; styles partly united, with 2-many stigmas; fruit a capsule, drupe or berry.

1. Leaves and stipules 4-7 in a whorl; -herbs with 4-angled stems; stipules often as large as the leaves; flowers small on axillary peduncles or in cymes; calyx truncate, corolla rotate with $3-4$ 
lobes; ovary 2-celled and ovules solitary; styles 2; fruit of 2 globular indehiscent carpels. Summer.

Galium, Bedstraw

G. circaezans. Glabrous; stems branched from the base; leaves and stipules 4 in a whorl, ovate to oval, nearly sessile; flowers few, greenish, lobes 4 acu. minate. Dry woods.

G. hispidulum. Almost glabrous; branches decumbent; leaves and stipules 4 in a whorl, elliptic-oblong, rather thick; flowers in clusters of 3 or 5 . greenish white, lobes 4 acute and hairy. Dry sandy soil.

G. triflorum. Somewhat hispid; branches weak, reclining; leaves and stipules 6 in a whorl, broadly-linear to elliptic, mucronate; flowers in clusters of 3. greenish or yellowish-white, lobes 4 acuminate; sweet-scented. Low shaded places.

G. pilosum. More or less hirsute; stems branched from the base; joints swollen; leaves and stipules 4 in a whorl, oval-ovate, nearly sessile, pellucid-punctate beneath; flowers numerous in clusters of 2 or 3 on short stiff peduncles, greenish yellow or purplish, lobes 4 acuminate. Open sandy woods.

1. Leaves opposite or in whorls of $3,-$ - $_{-}-{ }_{-}-{ }_{-}$

2. Shrubs or small trees, - - - - - - - - - - 3

2. Herbs,

3. Flowers in beads, solitary or panicled, axillary or terminal;-sepals 4 with bristle-like or chaffy bractlets; corolla tubular-funnelform with 4 lobes, white; ovary 2 -celled with solitary ovules; seeds with white arils, - - _ - Cephalantus, Bulton-Bush;

C. occidentalis. Glabrous, diffusely branched; leaves oblong to lanceolate peduncles longer thas the heads. Marshy ground. Summer.

3. Flowers in corymbose cymes, terminal or axillary:-stipules narrow, caducous; flowers showy, 5-parted; corolla tubular, greenish with brown or purple blotches, pubescent inside; ovary 2 celled with numerous ovules in each cell; fruit a capsule. - Pinkneya

P. pubens. Leaves oblong to oval, large; sepals linear, but some of them larger, ovate and pink colored. Riverbanks. Spring and Summer.

3. Plowers in 2-3 forked cymes, disposed in pedunculate terminal umbels;-sepals 5; corolla tubular to campanulate, scarlet-orange, 5-lobed; ovary 5-celled with numerous ovules in each cell; fruit a small black berry. Cultivated. Summer and Fall. - Hamelia patens

3. Flowers in few-flowered cymes; broad-leaved evergreen with large white double flowers, fragrant; calyx ribbed, with 5 long teeth.

Cultivated. - - - Gardenia florida (jasminoides), Cape Jessamine

4. Ovary 2-celled, fruit 2-carpeled, - _ - _ _ - - 5

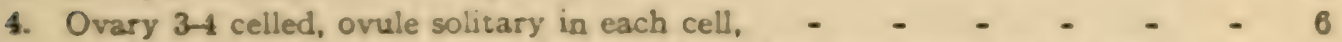

8. Ovule solitary in each cell;-stems or branches prostrate; leaves sescile, narrow, with sheathing stipules; flowers axillary; calyx 24 parted; corolla funnelform or salverform, 4-lobed.

Diodia, Bublon-weed

D. Virginiana. Leaves almost glabrous, oblong or oblong-spatulate; corolla ealverform, white. Wet soil. Spring to Fall.

D. teres. Leaves hairy. Linear to linear-lanceolate; corolla funnelform, white or piakish. Dry soil. Summer.

6. Ovules several in each cell; - -lowers 4-parted; capsule free at the apex; berbaceous or somewhat woody below, often with ciliate leaves; 
flowers often dimorphous, solitary or in corymbose cymes; corolla funnelform or salver-shaped,

Houstonia, Bluets

H. rotundifolia. Stem prostrate; leaves fleshy, oval to roundish, narrowed into a short petiole; corolla white; numerous cleistogamous flowers. In patches, in damp soil. Early Spring.

H. angustifolia. Stem much branched at the base; leaves linear, often clustered; corolla white, very hairy inside. Sandy pine-barrens. Spring and Summer.

6. Flowers paired, with the ovaries united, on one axillary or terminal peduncle;-evergreen herb with creeping stem; calyx 4-toothed; corolla 4-lobed, funnelform; ovary 4-celled, stigmas 4; flowers dimorphous; fruit of two 4-seeded druplets, crowned with the persistent calyx,

Mitchella, Twin-berry, Partridge-berry

M. repens. Usually in patches; leaves ovate to roundish, petioled; flowers fragrant, white or pinkish; fruit red or white. Shady woodland. Spring.

6. Flowers in terminal, involucrate clusters;--pubescent; stipules fringed; calyx 4-8 toothed; corolla 4-8 lobed; stigmas 3-4.

Richardsonia, False Ipecac

R. scabra. Annual; leaves oblong to lanceolate, undulate, nearly sessile; involucre of two unequal pairs of bracts; corolla funnelform, 6-lobed, white or pink. Sandy soil. Summer.

R. Brasiliensis. Perennial; leaves elliptic to oblong, short petioled; flowers as in preceding species, somewhat larger. Southward.

\section{Caprifoliaceae, Honeysuckle Family.}

Mainly trees and shrubs, the latter often twining, with opposite, mostly exstipulate leaves; flowers clustered, 3-5 parted; corolla tubular or rotate, the stamens alternate with its lobes and adnate to its tube; ovary inferior; fruit a berry or drupe.

1. Corolla rotate, 5-lobed,

1. Corolla tubular to long-campanulate, 2-lipped or 5-lobed, - $\quad$ - 3

2. Leaves odd-pinnate; fruit a baccate drupe with 3-5 1-seeded stonesshrubs or small trees with chiefly 5-parted white flowers in umbel-like corymbose cymes; drupes deep purple. Low ground. Early Summer. - _ - - - Sambucus Canadensis, Elder

2. Leaves simple; fruit a fleshy drupe with single stone;--shrubs or small trees with 5-parted white flowers in corymbose cymes.

Viburnum, Haw, Sloe

V. nudum. Shrub, obscurely pubescent; leaves petioled; cymes shorter than the peduncles; drupes deep blue. Swampy ground. Spring and Summer.

V. obovatum. Shrub or slender tree, glabrous; leaves narrowed into a petiole; cymes sessile; drupe black. Swampy ground. Spring.

3. Flowers in pairs on axillary peduncles, with 2 bracts and 2 bractlets; corolla 2-lipped, upper lip 4-lobed, lower lip narrow;-climbing vine with short-petioled, oblong or ovate leaves; corolla white, turning yellow, pubescent outside; berries black. Cultivated. - - Nintooa (Lonicera) Japonica, Joponese Honeysuckle

3. Flowers in whorls, sessile; corolla 2 -lipped or with 5 nearly equal 
lobes;-evengreen twining vine with oval or oblong lesves, the upper pairs connate; corolla scarlet or orange outside, yellow inside; berries scarlet. Margins of swamps and cultivated.

Lonicera sempervirens, Coral Honeysuckle, Wroodbine

3. Flowers solitary or in axillary cymes, often panicled; corolla 5-lobed or sometimes slightly 2-lipped;-shrubs with spreading. more or less arching branches, and petioled serrate leaves; corolia white, yellowish, or pink to crimson; fruit a slender 2-celled capsule with numerous minute seeds. Cultivated. Diervillea, Weigelia

3. Flowers in terminal panicles, corolla trumpet-shaped, 5-lobed;half evergreen shrub with ovate, serrate, short-petioled leaves; sepals 5 ; corolla white flushed pink. Summer. Cult.

Abelia grandifiora

\section{Valerianaceae, Valerian Family.}

Commonly heavy-scented herbs; stems dichotomously branched, or erect, or climbing, or almost absent; leaves opposite, entire to pinnate; flowers in panicled cymes, perfect, monœecious or diøecious; calyx 3-5 lobed or obsolete; corolla 3-5 lobed, tubular, funnel or salverform; stamens 1-4. fewer than the corolla-lobes, and adnate to its tube; ovary inferior, 3-celled or apparently 1-celled; style filiform, stigma sometimes cleft; fruit an achene or a nutlet.

Flowers perfect in terminal spicate or panicled cymes; calyx-border inrolled but at length spreading and forming plumose bristles; corolla funnel- or salverform, gibbous, 5-lobed, white or pink; stamens 3, ovary 1-celled, style 2-3 cleft. - - _ - Valeriana

V. scandens, Valerion. Stem climbing, branched; basal leaves entire, ovatecordate; stem-leaves terminately divided, long petioled; flowers very small, funnelform, in axillary and terminal panicles.

168. Asaraceae (Aristolochiaceae), Birthwort Family.

Herbs or woody vines with alternate, petioled, mostly cordate or hastate leaves, and solitary or clustered flowers; calyx present, corolla rudimentary or absent; stamens as many as calyx-lobes, or more; ovary inferior, usually 6-celled; fruit a capsule.

Flowers irregular, variously infated; calyx colored; stamens 6, rarely 4-10, adnate to the $4-6$ angled column formed by the styles;

capsule pendulous, \&-6 valved with numerous seeds.

Aristolochia, Duschman's Pipe

A. serpentaria, Snoke-roub. Low herb with a more or less ziszag stem and few oblong-lancerfiate, acuminate leaves on short petwies; Howers solitary or clustered on branched peduncles; calyx s-shaped. 3-lotsed. dull purple. Shady woods. Summer.

Some species are cultivated as: A. elegans with dark-purple flowers, blotched and waved with creamy-white; A. floribunda with purplish-red Ruwers and yellow 
centers; A. ridicula or Donkey Ears, pale yellow with purplish veins, the limb consisting of two narrow lobes; A. grandiflora, Goose-flower or Pelican-flower, pusple-blotched, and terminating in a slender filament.

\section{Cucurbitaceae, Gourd Family.}

Succulent herbs, usually trailing, or climbing by means of lateral tendrils; leaves alternate, palmately veined or lobed; flowers monœcious or diøcious; calyx 4-5 lobed; corolla with 5 petals, distinct, or more or less united, and inserted on the calyx; stamens $3-5$, distinct or variously united, anthers often contorted; ovary inferior, 1 - or 3celled; style 1, stigmas mostly 3 ; fruit a fleshy or pulpy berry (PEPO); seeds rarely solitary, mostly numerous.

1. Stems trailing and climbing,

1. Stems trailing and creeping,

2. Anthers straight or curved;-leaves lobed to palmately divided; tendrils simple; flowers small, monœeious or polygamous, campanulate, yellow or white, the pistillate ones solitary, the staminate racemed; ovary inserted in a disk, - _ - - Melothria

M. pendula. Climbing; leaves with 3-5 lobes; calyx very small; berries pendulous, dark purple or black. Light soil. Summer.

2. Anthers contorted,

3. Tendrils simple;-leaves entire or 3-7 lobed, the lobes shallowly toothed; connectives extended beyond the anther-cells;-stems trailing or climbing, roughly pubescent; flowers yellow, monœcious; sterile clustered, with 3 short stamens; fertile flowers solitary, without staminodia, 1-celled ovary and obtuse stigmas; pepo pulpy, with numerous whitish seeds. Cultivated. - Cucumis

C. melo, Musk-melon, Cantaloupe. Leaves toothed or shallowly lobed; fruit smooth; the softer-rinded kinds are called: Nutmeg- or Netted Melon.

C. sativus, Cucumber. Leaves lobed, the middle lobe more prominent; fruit oblong, prickly when young.

C. Anguria, Gherkin. Leaves sinuate-lobed; fruit ovoid, prickly.

3. Tendrils 2-branched;-corolla with 5 distinct petals; fruit of various shapes, smooth, many-seeded;-stems climbing; foliage clammypubescent; leaves ovate-cordate, toothed or sometimes 3-5 lobed; flowers white, sometimes striped with green, monccious, solitary; the sterile long-pedicelled, with 5 distinct stamens; the fertile short-pedicelled, with 3 thick 2-lobed stigmas; pepo with a woody rind and fleshy pulp. Waste places and planted.

Lagenaria vulgaris, Bottle Gourd, Calabash

4. Corolla rotate;-tendrils 2-3 branched; leaves 3-7 lobed, the lobes toothed or again lobed; connective not extended beyond the anthercells;--stems stout, trailing, zigzag; flowers pale yellow, monœcious, solitary; sterile flowers with 3 short stamens; fertile flowers with staminodia, an elongated ovary, and reniform stigmas; pepo large, seeds white or black. Cultivated, and running wild as citron.

Citrullus vulgaris, Watermelon

4. Corolla campanulate;-tendrils 2-many branched; leaves thick, 3-5 


\section{FAM. 170.}

lobed, cordate: flowers yellow or orange, showy, mnnœcinus, solitary; sterile flowers with 3 stamens; fertile flowers with 3 staminodia, a 1-celled ovary, and 3-5 stigmas, 2-lobed; calyxtube bristly. sepals linear; corolla bright yellow or light orange, pubescent, berries green, variegated with paler green or yellow. Cultivated,

a. Stems long-running,

a. Stems not long-running.

b. Stems and petioles prickly; leaves $3-5$ lobed; calyx-lobes narrow. not leaf-like; corolla-tube expanding upwards, border with short erect lobes; fruit-stalk hard and furrowed, not enlarged next the fruit; fruit various in form, color and size, - C. pepo,

- Cucurbita

Stems less prickly, sometimes soft-hairy; leaves lobed but more rounded than of the preceding species; calyx-lobes longer, often leaf-like; corolla-tube expanding upwards, border with large erect lobes; fruit-stalk deeply furrowed, and much enlarged next the fruit.

C. moschata (meloniformis), Cushaw, Crookneck

c. Stems often hairy; leaves orbicular or reniform, commonly not lobed; corolla-tube not expanding; fruit-stalk soft and spongy, not furrowed, and not prominently enlarged next the fruit; fruit various, but not warty nor crookneck shaped. - C. maxima, Squash

c. Like C. pepo, but plant compact, little or not running.

C. pepo, var condensa, Scallop

c. Stems slender, leaves usually prominently lobed; fruit small, hard, egg- or pear-shaped, often striped; inedible.

C. pepo, var. ovifera, Gourd

4. The Luffa, Rag-gourd or Dishcloth-gourd, is grown for the fibrous interior of the dried fruit, which when bleached and prepared may be used as bath-sponge, etc.-Flowers white, sometimes striped with green, monoecious; the sterile in a long-peduncled raceme, the fertile solitary or short-peduncled; corolla yellowish-white; stamens 3 on the calyx-tube; pepo long, gourd-like, dry when ripe.

\section{Campanulaceae, Bell-flower Family.}

Herbs with alternate, exstipulate simple leaves and perfect, regular flowers; calyx 3-5 lobed; corolla 5-lobed; stamens 5, free from the corolla, distinct, often ciliate; ovary inferior, $2-5$ celled; style single, often hairy above; stigmas as many as the cells in the ovary; fruit a capsule with many seeds.

1. Corrlla campanulate; inforescence racemose or paniculate;-caly $\pi$ and corvlla 5-lobed; stamens 5, broad below; ovary 3-5 celled. stigmas $3-5$.

Campanula, Bell-flower

C. Floridana. Smooth; stems wiry; reclining; leaves lanceolate, sessile; corolla small, as long as the sepals, blue or pale-purple. Around lakes. Spring and Summer.

1. Corcila rotate; inforescence spicate;-flowers of two kinds, the earlier ones cleistogamous, usually with $3-4$ lobed calyx and an 
undeveloped corolla; the later ones with calyx and corolla 5lobed; stamens 5 ; ovary 3 celled and stigmas 3 . Fields. Spring. to Fall. - - - - - Specularia, Venus' Looking-glass

S. perfoliata. Stem erect, prickly on the angles; leaves triangular-cordate, crenate or serrate, clasping; flowers 1-several, sessile in each axil, blue.

S. biflora. Stem erect, prickly on the angles; leaves ovate, oblong or lanceolate, entire or crenate-serrate, sessile; flowers $1-2$ in an axil, sessile, blue; style colored. Crow's Bluff.

\section{Lobeliaceae, Lobelia Family.}

Herbs with milky poisonous sap; leaves simple, alternate, exstipulate; flowers irregular, 5-parted, corolla often bilabiate, the tube split on one side to the base; ovary inferior, 2-5 celled, with 1 style and fringed stigmas; fruit a 1-many celled capsule or a berry; seeds numerous.

Flowers in spikes, racemes or panicles subtended by bracts; stamens monadelphous, anthers in a ring around the style, all, or 2 of them, bearded at the apex; ovary 2-celled; stigmas 2-lobed,

1. Corolla red;-stem stout, usually simple; leaves oblong or elliptic to lanceolate, serrate or dentate; flowers in a slender raceme. Muddy banks. Summer and Fall. - - L. cardinalis, Cardinal-flower

1. Corolla blue or white, - _ - - - _ - - - - 2

2. Sepals with deflexed auricles at the base;-more or less hairy; stem simple, slender; leaves lanceolate or oblong, nearly entire; the lower short-petioled, the upper sessile; flowers bright blue, in slender often one-sided racemes. Low ground. Late Summer.

2. Sepals without auricles,

3. Corolla large, about $2 \mathrm{~cm}$. long;-plant glabrous; stem erect or decumbent, simple; leaves few, linear, thick, sessile; flowers pale blue, in one-sided 3-9 flowered racemes. Wet pine-land. Spring to Fall. - - - - - - - - - L. glandulosa

3. Corolla small, less than $1 \mathrm{~cm}$. long, - - - - - $_{-} \quad 4$

4. Stem scape-like;-plant smooth; stem simple or branched above; leaves mostly basal, linear to lanceolate-spatulate; sessile or petioled; flowers pale blue or white, in slender racemes. In and about pine-barren swamps. Spring to Fall. - - - L. paludosa

4. Stem leafy;-plant glabrous; stem slender, erect or branched at the base; leaves few, entire or crenate, below reniform or orbicular, above obovate or ovate; flowers bright blue in few-flowered racemes. Flat pine-land. Summer and Fall.

L. Feayana

\section{Ambrosiaceae, Ragweed Family.}

Herbs, rarely shrubs, with alternate leaves, or on the lower part of the stem opposite; flowers very small in inconspicuous heads; involucres of few bracts; staminate flowers tubular, 5-toothed; stamens 5, distinct, with anthers converging; corolla of pistillate flowers a short tube, 
or manting; calyx a mere border or absent; ovary 1-celled with 2 hairy stigmas; achenes naked, or enclosed in the accrescent nut-like or bur-like involucre.

1. Sterile and fertile flowers in different heads;-the sterile heads in terminal spikes or racemes, the fertile heads solitary or clustered below the sterile; the staminate involucres cup-shaped of 5-12 partially united bracts and 5-20) fowered; receptacle flat. naked or with filiform chaff; the pistillate involucres turbinate or subglobose, 1-flowered, with several spines or tubercles in one row; corolla wanting; achenes without pappus; flowers whitish.

Summer and Fall. - _ _ _ _ - - Ambrosia, Ragweed

A. hispida. Hirsute to hispid; leaves mostly opposite, 2-3 pinnatifid, or pinnately divided; receptacle chaffy. Dune-sand.

1. Sterile and fertile flowers in the same heads;-heads small, axillary. drooping; bracts of the involucre few; receptacle chaffy; flowers inconspicuous, whitish; the marginal ones, 1-6, pistillate with tubular corollas; the central ones perfect but sterile, with funnelform corolla, 5-lobed; achenes without pappus. Summer and Fall.

Iva, Marsh Elder

I. imbricata. Somewhat shrubby, smooth; leaves mostly alternate, numerous, fleshy, linear, entire, sessile; heads short-peduncled; bracts 6-9 suborbicular. In sand, on the coast.

I. frutescens. Shrubby; leaves mostly opposite, pubescent, ovate to linear. serrate, short-petioled; heads short-peduncled; bracts $3-5$, orbicular. Salt marshes.

I. microcephala. Annual, rough; leaves often alternate, narrowly linear, entire or slightly toothed; heads sessile; bracts 3-5, narrowly linear. Dry pine. land.

\section{Carduaceae, Thistle Family.}

Herbs, rarely shrubs with opposite, alternate, or all basal leaves without stipules; flowers in a head, on a receptacle, surrounded by an involucre; calyx of bristles, awns or scales, forming pappus at maturity, or calyx absent; corolla of 5 petals, for the greater part united; stamens 5 , alternate with the corolla-lobes, the anthers syngenesious; ovary inferior, 2-carpeled, 1-celled, with 1 style and 2 stigmas; fruit an achene.

1. Heads discoid, i. e. corollas all tubular, - _ _ _ _ _ $~ 2$

1. Heads radiate, i. e. central corollas (disk-flowers) tubular, and marginal corollas (ray-llowers) ligulate, _ _ _ _ _ - $~ 12$

2. Heads with the flowers all perfect, - _ _ _ _ _ - - 3

2. Heads with the central flowers perfect, marginal flowers pistillate. - 11

2. Heads direcious; - shrubs with alternate leathery leaves and heads in corymus or panicles; bracts in several rows; receptacle flat. pitted. without chaff; corollas of staminate heads tubular, of pistllate heads filiform; pappus of the forner short, of the lat- 
ter consisting of long hair-like bristles in 1-2 series; flowers white,

Baccharis

B. halimifolia. Leaves numerous, suborbicular to linear-elliptic; heads numerous in peduncled clusters of 3-5. Along the coast. Summer and Fall.

B. glomeruliflora. Leaves rather few, spatulate to cuneate-obovate; heads solitary and sessile, or few in nearly sessile clusters. About pine-land swamps. Fall and winter.

B. angustifolia. Leaves numerous, linear; heads numerous or few in peduncled clusters, or solitary on short peduncles. Brackish marshes. Fall.

3. Flowers yellow;-rigid herbs with alternate leaves and small heads often in corymbs; bracts in several rows; receptacle flat, sometimes with teeth around the depressions; pappus of 1-2 series of rigid hair-like bristles. In pine-land. Summer.

Chondrophora (Bigelovia)

C. nudata. Stems mostly simple, wand-like; leaves mainly basal, spatulatelanceolate, the stem-leaves scattered, linear.

C. virgata. Similar to preceding; lowest leaves linear-spatulate, the stem-leaves filiform; heads larger.

3. Flowers white, blue or purple, - - - - - - - -4

4. Receptacle chaffy, - - - - - - - - - - 5

4. Receptacle bristly; leaves spine-tipped;-herbs with sessile or decurrent, alternate or basal, toothed, lobed or pinnatifid leaves; involucre of many rows mostly spine-tipped; receptacle flat or convex; pappus of plumose bristles, - - Carduus (Cirsium), Thistle

C. repandus (C. repandum). Stem very leafy, the leaves spreading; narrowoblong in outline, pinnately-lobed; plant webby; flowers purple. Dry pine-land. Spring to Fall.

C. muticus (C. muticum). Stem tall, branching; leaves numerous, deeply 1-2 pinnatifid, the lobes lanceolate. spiny; bracts of the involucre woolly, cuspidate or with recurved tips; flowers purple. Low thickets. Late Summer and Fall.

C. spinosissimus (C. horridulum). Stem woolly; lower leaves spatulate in outline, twice pinnatifid; the upper ones oblong to lanceolate in outline, often pinnatifid; heads surrounded by a whorl of spiny bracts; flowers mostly purple (var. Elliottii), or yellowish. Sandy soil. Spring and Summer.

4. Receptacle naked,

5. Leaves opposite; flowers white;-rough herbs with 3-4 angled stems and peduncled heads; bracts in 2-3 rows; pappus of 2-several caducous awns,

M. nivea (hastata). Stems blotched with purple; leaves hastately-lobed, serrate; bracts of involucre scale-like. Light soil. Spring and Summer.

5. Leaves alternate; flowers purple;-erect herbs with showy heads in terminal corymbose cymes; bracts in several rows, appressed; pappus of plumose or barbed hair-like bristles. - - - Carphephorus

C. corymbosus. Stem tall and like the leaves pubescent; lower leaves spatulate to oblong, upper ones much smaller and sessile; heads numerous, bracts of involucre scarious-margined. Sandy pine-land. Summer and Fall.

6. Bracts of the involucre in one row;-stems corymbosely branched; leaves alternate; heads corymbose; bracts about 5 , but often accompanied by a few small ones at the base; pappus copious, 
of soft capillary bristles; flowers white or pinkish.

Mesadenia (Cacalia), Indian Plarlein

M. (C.) ovata. Stem terete; leaves ovate to oval, 3-5 palmately-veined, the lowest long-petioled; heads often numerous. Swampy woods. Summer.

M. (C.) lanceolata. Stem terete; leaves linear to lanceolate, with mangined petioles; beads relatively few. Wet pine-land. Spring to Fall.

6. Bracts of the involucte in 1-2 rows, imbricated; pappus scaly. (See 170.)

6. Bracts of the involucre in 2-several rows, - - _ - _ - 7

7. Pappus double, the outer series of scales or stout bristles, the inner of rough, hair-like bristles;-herbs or shrubby plants with alternate leaves and purple heads in panicled or corymbed cymes; bracts in several rows. Summer. - _ - Vernonia, Iron-weed

V. angustifolia. Leaves nearly smooth, narrowly linear; bracts of involucre lanceolate to oblong, with somewhat spreading tips; pappus purplish. Sandy soil.

7. Papfus single or double, bristly from a scale-like base;-erect herbs, 3-9 dm. tall, corymtosely branched or simply forked above; the small 3-5 flowered heads collected into glomerules which are subtended by 2 or 3 leaf-like bracts; the purple, blue or whitish corollas deeply cleft on the inner side; stigmas pubescent. Sandy soil. Summer and Fall. - - - Elephantopus, Elephant's Foob

E. Carolinianus. Stem hairy; leaves hairy, chiefly cauline, oblong to oval, crenate and repand.

E. tomentosus. Stem hirsute; leaves hirsute-tomentose, chiefly basal, oblong to oblanceolate, crenate-serrate.

7. Pappus in 1-2 rarely more, series of barbed or plumose bristles, - - $\quad 8$

7. Pappus in 1 series of hair-like bristles or scales, - _ _ _ - 10

7. Pappus wanting;- -erect herbs, corymbosely branched, with aitemate, entire, glabrous leaves; heads peduncled, few-flowered; involucres and fowers of each head punctate with resinous glands; tracts linear, in two series; receptacle naked. - _ Hartwrightia

H. Floridam. Lower leaves oblong, narrowed into margined petioles; the upper linear, smaller and remote; corollas white. Low ground. Summer and Fall.

8. Perennial caulescent herbs - _ - _ - _ - - - 9

8. Low shrubs; -leaves numerous, altemate, leathery; heads in dense corymbose cymes; bracts herbaceous in about 5 rows of $3-4$ each; anthers appendaged at the top; pappus in 2-more series. copious, - - - - - - - - - Gurberia (Liatris)

G. (L.) fruticosa. Leaves spatulate or obovate, pale; heads 5 -flowered, crowded. Sandy soil. Spring to Fall.

9. Bracts of involucre nearly equal, slightly imbricated; heads in thyrsoid or corymbose pancles:-leaves alternate, the basal ones with broad petioles, the cauline ones sessile or clasping; fowers purjish or white. Late Summer. - - - - Trilisa (Liatris)

T. (L.) paniculate. Stem viscid-putescent; leaves smooth. elliptic to lanceolate; beads mostly 5-flowered, in thyrsuid pancles. Damp pine-barrens.

I. (L.) odoratissima, Vonulla-plent. Deer-longue. Stem smooth; lowest leaves spatulate or ublong. the upper oval or otlong. small, sessile; heads ractly 7-8 flowered, in corymbose panicles. Platwoods.

9. Bracts of involucre in several rows, the inner successively longer; 
heads mostly in spikes or racemes;-leaves alternate; heads rose-purple or white. Summer and Fall.

Laciniaria (Liatris), Button Snakeroot or Blazing Star

L. spicata. Leaves numerous, linear, smooth; spikes long, cylindrical, often dense; involucres rounded at the base, sessile, the bracts glabrous or nearly so, copiously punctate; heads sessile, 8-12 flowered, purple. Moist soil.

L. Chapmanii. Leaves narrowly linear, numerous on the lower, much reduced and sessile on the upper part of the rigid stem; spikes dense, plumose when mature, heads mostly 3 -flowered; bracts ovate to lanceolate. Sand-hills.

10. Erect herbs or shrubby plants;-leaves alternate, opposite, or whorled; heads in corymbs or panicles; receptacle flat; involucres narrow with scarious or nembranous bracts; anthers appendaged at the apex; flowers mostly white. Spring to Winter, - Eupatorium

a. Leaves compound with narrow-linear segments, - - - - - b

a. Leaves simple, at most toothed or incised, - _ _ _ - - - c

b. Leaves very numerous, with narrow-linear segments;-plant fennel-scented; heads 3-5 flowered, in panicles; bracts lanceolate with scarious margins. Old fields.

E. capillifolium (foeniculaceum), Dog-fennel

b. Leaves numerous, compound on the lower part of the stem to entire on the upper part, segments linear;-heads 5-flowered, in panicles; bracts narrowly lanceolate. Dry soil.

E. compositifolium (coronopifolium)

c. Leaves petioled, - - - - - - - - - - - d

c. Leaves chiefly sessile, - - - - - - - - -

d. Heads 5-flowered, - - - - - - - E. mikanioides

d. Heads 10-30 flowered, - - - - - - E. aromaticum

e. Leaves linear to lanceolate, - - - - - - - - 1

e. Leaves lanceolate to ovate or oblong, - $\quad$ - $\quad$ - $\quad$ - $\quad$ - $\mathbf{g}$

f. Smaller leaves clustered in the axils of the larger, - E. hyssopifolium

f. No smaller leaves present, - - - _ - - E. leucolepis

g. Inner bracts of involucre with white tips, - - _ - E. album

g. Inner bracts of involucre petaloid, - _ _ _ E. petaloidum

g. All bracts of involucre alike, - - - _ - _ - -

h. Bracts of involucre with scarious margins and apex, - E. cuneifolium

h. Bracts of involucre canescent, - - - - - - - - i

i. Branches of inflorescence alternate, - - - E. verbenæfolium

i. Branches of inflorescence opposite, - - - - - E. scabridum

10. Resembling Eupatorium, but receptacle conical or hemispherical.

Conoclinum

E. (C.) cælestinum, Mist-Flower. Cultivated as a bedding-plant with small blue or violet flowers in cymose heads; leaves ovate to deltoid-ovate. Shaded ground. Summer.

10. Low herbs with simple leaves; small heads of flowers in corymbs; bracts of involucre in $2-3$ rows; receptacle flat or nearly so; pappus simple of $\mathbf{5}$ or more scales. Cultivated for bedding. Summer.

Ageratum

A. conyzoides. Stems often branched; leaves ovate to deltoid, crenate-serrate on short petioles, pubescent; flowers blue, white or rose.

A. (Conoclinum) Lasseauxii. Leaves lanceolate to elliptic; flowers rose.

10. Herbaceous twining vines;-leaves opposite, slender-petioled, cor- 
date to hastate; heads 4 -flowered, in corymbose clusters; bracts 4 or 8, nearly equal: flowers white or pink. - Willugbaeya (Mikania)

W. (M) scandens. Stems sometimes densely matted; heads numerous with narrow involucres and linear bracts. Swampy places. Summer and Fall.

11. Bracts of the involucre narrow, in one row, sometimes accompanied by smaller bracts;-coarse erect herbs with alternate, toothed to pinnatifid leaves; heads in corymbs and panicles; fowers white or greenish. Open woods and burnt-over ground. Summer and Fall.

Erechtites, Fire-weed

E. hieracifolia. Stems tall, simple or much branched; leaves lanceolate or spatulate-oblong on winged petioles below, sessile or clasping above; pappus white, silky.

11. Bracts of the involucre broad, in few rows, persistent;-herbs or shrubs with stems branched above; leaves alternate, oblong to ovate, prominently veined, petioled, or the upper sessile and clasping; heads in cluster-like cymes; receptacle flat, naked; central flowers perfect but mostly sterile; anthers sagittate; pappus a single row of scabrous capillary bristles,

Pluchea, Marsh Fleabane

P. foetida, L. (bifrons D. C.) Heads pale purple or white, in almost sessile clusters; inner bracts acute, the outer acuminate, ciliate near the tips. Low ground. Spring and Summer.

P. longifolia. Leaves firm, mucronate; heads purplish, in dense terminal clusters; bracts ciliate, the inner acute, the outer more obtuse. Swamps. Summer.

P. purpurescens. Leaves short-petioled; corollas bluish-purple; bracts granulose, the inner acute or acuminate, the outer mucronate. Sandy soil. Summer and Fall.

P. camphorata. Leaves thickish, nearly sessile; heads light purple, in dense clusters; bracts ciliate, the inner long-acuminate. Salt marshes. Summer and Pall.

11. Bracts of the involucre linear, in few rows, deciduous at maturity;herbs with the leaves alternate, mostly tomentose or woolly. decurrent on the stem; heads in compact spikes; receptacle naked or minutely hairy; central flowers perfect but mostly sterile; anthers sagittate; pappus a single series of equal capillary bristles, - - - - Chaenolobus (Pterocaulon),

Black-root

C. undulatus (P. pycnostachyum). White-tomentose; stem simple; leaves oblong to lanceolate, wavy, smooth above; spikes stout, woolly, white. Sandy pine-land. Spring and Summer.

11. Bracts of the involucre scarious, in several rows;-herbs with woolly foliage; leaves narrow, alternate. sessile or decurrent; receptacle usually pitted; anthers sagittate; pappus a single row of capillary bristles, - - - Gnaphalium, Cudweed, Eterlosting

G. obtusifolium (polycephalum), Rabbil Tobacco. White, woolly; leaves linear, sessile, the basal ones oblanceolate; heads numerous with few perfect flowers, corymbose; bracts white or rusty. Dry soil. Summer and Fall.

G. purpureum. White-woolly or silvery; leaves spatulate to linear; heads crowded, in spikes or racernes. Cormmon. Spring to Fall. 
12. Ray-flowers neutral, - - - - - - - - - 30

13. Disk-flowers perfect and fertile, - - _ - - - - - 14

13. Disk-flowers perfect and sterile, - - - - - - - - - 27

14. Receptacle naked,

14. Receptacle pitted,

14. Receptacle chaffy,

15. Ray-flowers yellow,

15. Ray-flowers white or purple,

16. Bracts of involucre narrow, mainly in 1 row, the few outer bracts irregular; - herbs with alternate, sometimes mainly basal leaves, pinnatifid or parted; pappus copious, of capillary bristles,

Senecio, Squaw-weed, Grourdsel

S. obovatus. Leaves near the base of the stem, spatulate to obovate, narrowed into broad petioles; few stem-leaves pinnatifid; heads in corymbs, deep yellow. In moist soil. Spring.

S. lobatus. Stem furrowed, hollow, more or less branched above; leaves pinnately divided, with rounded lobes; heads showy; ray-flowers $6-12$ yellow. Low ground. Spring.

16. Bracts of involucre narrow, in 1-2 rows, spreading or reflexed; herbs with alternate, often decurrent leaves, entire or toothed; heads peduncled; pappus of 5-8 pointed or awn-tipped scales,

Helenium, Sneeze-we ed

H. autumnale. Stems branched, leaves oblong to elliptic, often acuminate; receptacle subglobose. Low ground. Late Summer and Fall.

17. Pappus a scaly cup or wanting; -herbs with alternate, toothed to dissected leaves; bracts of involucre in several rows; receptacle flat or convex; disk-flowers with round or winged corolla-tubes and truncate or brush-like stigmas, - - - - Chrysanthemum

C. leucanthemum (Leucanthemum vulgare), Ox-eye Daisy. Leaves spatulate to linear, serrate or pinnatifid; heads terminal, solitary, large, longpeduncled, with white or pink ligules and light yellow disk; pappus absent. Fields. Spring to Fall.

Many cultivated species in various colors and sizes.

17. Pappus of 6-12 narrow ribbed scales;-herbs with narrow, mainly alternate leaves; heads discoid or radiate, in corymbs; bracts of involucre in 1-2 rows; receptacle flat, naked; rays pistillate or wanting; disk-flowers perfect and fertile, - Polypteris (Palafoxia)

P. integrifolia. Stems corymbosely branched; leaves linear; bracts of involucre scarious or petaloid; ray-flowers wanting; corollas of disk white or flesh-colored. Dry pine-land. Summer.

17. Pappus bristly in 1 series, sometimes with a row of shorter bristles outside;-caulescent almost scapose herbs, with alternate, entire or toothed leaves; involucres broad with narrow bracts in 1-2 rows, reflexed when mature; disk yellow. - Erigeron, Fleabane

E. vernus (nudicaulis). Almost smooth; stems scapose, solitary or tufted, corymbosely branched above; basal leaves spatulate to oval, petioled; stemleaves scaly; rays 20-30, white or pink. In sand. Spring and Summer.

E. pulchellus (bellidifolius). Villous; stem solitary; basal leaves spatulate to elliptic; stem-leaves oblanceolate; heads solitary or few, showy; rays about 50 , violet or bluish-purple. Open woods. Spring.

E. ramosus (strigosus.) Rough-pubescent; stem branching above; leaves spat- 
ulate to linear; heads numerous with white or pale-pink rays, about 60 . Dry soil. Spring to Fall.

B. quercifolius. Hoary-pubescent; stems branchinz above; lower leaves ob. lanceolate or pinnatifid narrowed into mangined petioles; upper lcaves few lanceolate; rays about 150, purplish to flesh-colored. Open woods. Spring.

E. Philadelphicus. Hirsute; stems more or less branched above; lower leaves spatulate or oblong, coarsely toothed; upper leaves oblanceolate, sessile; rays about 125 , bright pink. Pine-land. Summer. (The last two species found on Hontoon-island.)

18. Ray-flowers yellow, - - - - - - - - - - 19

18. Ray-flowers not yellow, - - - - - - - - $~ 21$

19. Pappus single, or in 2 nearly equal series of capillary bristles, - - $\quad 20$

19. Pappus double, the inner series of rough, hair-like bristles, the outer of small scales or bristles;-pubescent herbs with alternate lesves and showy heads in corymbs; bracts of involucre in several rows, - - - - - - - Chrysopsis, Golden Aster

C. graminifolia. Foliage silvery-silky; leaves linear, not clasping, the lower conspicuously longer than the upper. Sandy pine-land. Summer and Fall.

C. oligantha. Foliage silvery-silky below, glandular above; leaves linear, those on the stem few and clasping; heads long-peduncled. Low pine-land. Spring.

C. Mariana. Foliage villous; leaves spatulate to oblong; the lower ones narrowed into petioles, sandy soil. Summer and Fall.

C. scabrella. Foliage rough glandular; leaves numerous, linear, sessile; bracts of involucre rigid, firm-pointed. Dry pine-land. Fall and often through Winter.

C. trichophylla. Foliage villous; leaves numerous, the lower spatulate, those of the stem oblong to linear; heads often numerous. Pine-land. Summer and Fall.

C. hyssopifolia. Foliage glabrous; basal leaves in a dense rosette, those of the stem crowded. from spatulate to linear. Pine-land. Summer.

20. Perennial herbs, sometimes shrubby near the base; ray-flowers fewer than disk-flowers;-leaves alternate, simple, often toothed; heads small in panicles, racemes or thyrses; involucre of several rows; rays in one series. Late Summer and Fall.

Solidago, Goldewrod

S. odora. Stems usually simple; leaves anise-scented, the lower linear-spatulate to linear-oblong, the upper leaves lanceolate to linear; heads 5-7 tlowered in a broad one-sided panicle. Dry soil.

S. Chapmanii. Compared with the preceding: stouter, more pubescent; less scented. Pine-land.

S. rugosa (altissima). Stems branching above; leaves numerous, the lower spatulate to oblong, the upper elliptic to lancenlate, sharply toothed; beads 10-15 flowered in a one-sided panicle. Dry soil.

S. tortifolia. Stems slender; leaves more or less twisted. linear; heads small, numerous, 6-9 flowered in a wide one-sided panicle. Sandy soil near the coast.

S. Bootii. Stems purplish, branching above; leaves not numarous or few. the lower spatulate to oblong-spatulate, the upper narrow-elliptic; heads about 12 flowered in a widely spreading elongated panicle. Sandy soil.

20. Shrubby plants;-leaves aiternate, narrow, with rounded or angu- 
lar depressions; heads numerous, 4-7 flowered, rays 1-3; bracts in few rows; pappus brownish,

C. (Solidago). pauciflosculosa. Viscid. Low sandy soil. Fall.

Chrysoma:

21. Ray-flowers few, about 5;-herbs with alternate, entire or toothed leaves; heads 12-15 flowered, corymbose; bracts leathery in few rows; disk yellowish or purplish, rays white or pink; pappus of numerous scabrous bristles, - - - - - Sericocarpus

S. bifoliatus (tortifolius). Stem grayish-pubescent, leaves obovate, short, sessile; pappus white. Sandy pine barrens. Summer and Fall.

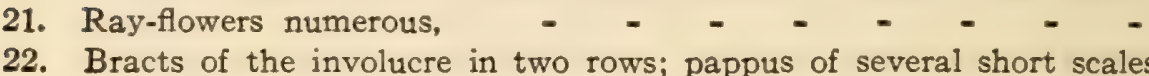
accompanied by 2-4 awns; - large smooth herbs with alternate, narrow, sessile leaves; heads numerous, receptacle convex or conical. Fall.

B. diffusa. Stem slender, much branched; rays white. Low ground.

22. Bracts of the involucre in 3-5 rows; pappus of a single row of bristles;- -herbs with alternate leaves; the radiate heads collected in corymbs, racemes or panicles, surrounded by an involucre of imbricated bracts in several rows; receptacle flat or convex, sometimes fimbrillate; disk-flowers yellow, changing to red, brown or purple; rays white, pink, purple, blue or violet; pappus in 1 , rarely 2 , series, bristly. Late Summer and Fall.

Aster

a. Basal and lower cauline leaves relatively narrow, with the base contracted into a petiole; upper cauline leaves sessile or clasping;--stem trailing, usually pubescent; leaves short, entire, elliptic to lanceolate, broadly clasping; heads solitary or clustered at the ends of the leafy branches; bracts narrow, with spreading or recurved dark-green tips; rays pale purple or pink.

Swamps. - - - _ - _ - - A. Carolinianus

a. Cauline leaves merely sessile, - - - - - - - - - - - - b

b. Leaves fleshy;--scattered, linear, those of the branches scalelike; heads few, terminal; bracts green on the back or at the tips, imbricated in 5 rows; pappus tawny; rays purple to nearly white. Salt marshes. - - - _ - - A. tenuifolius

c. Rays purple, lilac or violet, - - - - - - - - - d

c. Rays pale-purple or white - - - - - - - - e

d. Leaves silky or canescent; heads in a raceme;-leaves oblong to linear, sessile; bracts linear, appressed, and like the leaves grayish-white, in 4-5 rows, with green tips; pappus tawny; rays $10-15$, lilac. Sandy soil. - - _ - - - A. concolor

d. Leaves rough, adnate to the stem and branches; heads small, few, scattered, terminating the scaly branches;-basal leaves obovate, few; cauline leaves small, oblong to lanceolate, numerous; bracts linear with dark-green tips; rays violet. Dry pine land. - - - - - - - - - A. adnatus

d. Leaves rough, more or less reflexed; heads small, few, scattered, terminating the scaly branches;-basal leaves spatulate, the cauline rigid, oblong to ovate, ciliate; bracts with dark-green tips; rays 14-24. Dry pine land.

- A. squarrosus

e. Heads numerous, terminating slender branchlets;-stem smooth, paniculately branched; basal leaves spatulate, stem-leaves linear or linear-lanceolate, often reflexed; those of the branches 
scale-like; bracts in about 4 rows with green, tapering tips; rays 15-30 white, rarely pale pink. Sandy or low soil.

- A. dumosus

e. Heads not numerous, in racemes or spikes;-stem and slender branches more or less rough-pubescent; leaves linear; sessile, rigid; bracts smooth, linear, acuminate; rays few, short. purplish white. Along the coast. - - - - - A. racemosus

23. Shrubs;-leaves fleshy, simple, opposite, slightly connate, heads solitary, peduncled; bracts in 2-3 rows; receptacle convex; stigmas of the disk-flowers hispid; pappus a toothed crown; rays few, yellow. Saline marshes, - _ _ - Borrichia, Sea Ox-eye

B. frutescens. Leaves linear-spatulate to obovate, cuspidate. Late Summer.

23. Herbs,

24. Ray-flowers persistent on the achenes;-leaves opposite, 3-ribbed, entire or sparingly toothed, sessile; receptacle conical; heads solitary on long-peduncles; bracts of the involucre in 3-1 rows. appressed; ray-flowers red, purple, yellow or variegated; pappus of 1-several awns or teeth, or absent; achenes of the rays 3-angled, those of the disk flattened. Cultivated. - Crassina (Zinnia)

24. Ray-flowers deciduous from the achenes, - _ - _ - - 25

25. Receptacle flat to convex;-stems erect or procumbent with opposite narrow leaves; heads inconspicuous; involucre of about 2 rows of bracts; receptacle chaffy; ray-flowers pistillate, diskflowers peffect. chiefly fertile; pappus of several short teeth, or wanting,

E. aba. Leaves elliptic to linear, sessile; rays white. Wet places. Fall.

25. Receptacle conver or conical, - - _ - - - - - 26

26. Leaves opposite, petioled;-heads peduncled; bracts in about 2 rows, narrow; pappus of 1 -several awns. - - - - Spilanthes

S. repens. Stems decumbent. slightly pubescent, leaves ovate to lanceolate, serrate, narrowed into a petiole; rays yellow. Riverbarks. Spring to Fall.

26. Leaves alternate or opposite, decurrent;-bracts of involucre in few rows, narrow; pappus of $1-3$ awns, sometimes accompanied by as many scales, _ _ _ _ _ - Verbesina, Crownbeard

$\boldsymbol{\nabla}$. Virginica. Stem winged; leaves alternate, lanceolate to ovate, serrate; heads in corymbs; ray-flowers white. Dry ground. Summer.

27. Disir-flowers bilabiate;-stemless perennial herbs with basal leaves. smooth above and white-tomentose beneath; the simple scape bearing the solitary head; receptacle naked; bracts of the involucre narrow in few rows; pappus of numerous soft bristly hairs, - - - - - - - - Thyrsenthema (Chaptalia)

T. semiflosculare (C. tomentosa). Leaves oblong to oblancenlate; heads nodding; disk-flowers white or purplish, ray-flowers usually purple. Low pine barrens. Spring and summer.

27. Disk-flowers 5-lobed, - - - - - - - - - - 28

28. Heads conspicuous, achenes flattened, - _ _ _ - - $~-29$

28. Heads conspicuous; achenes short, thick, not Rattened;-coarse branching herbs, sometimes shrubly, with opposite leaves: involucre double, the outer row of about 5 tracts with an inner row of thinner bracts, subtending the achenes; receptacle flat. chaffy; beads of yellow flowers in corymbose panicles.

Polymnia, Leaf-cup 
P. uvedalia. Leaves broadly ovate, 3-5 lobed, contracted into a short petiole ray-flowers 10-14, longer than the involucre, bright yellow. Damp soil. Summer.

28. Heads inconspicuous; achenes short and thick, not flattened;coarse pubescent herbs with opposite, often leathery leaves; heads in the axils of leaf-like bracts; involucre double, 5 outer bracts herbaceous and several small inner bracts which form a burr around the achene; receptacle concave or convex; ray-flowers few, yellowish; pappus absent.

A. australe (xanthioides). Prostrate; leaves ovate to rhombic, serrate-dentate, on short peduncles; bracts prickly. Dry soil. Spring to Fall.

29. Leaves opposite; heads few, peduncled; pappus a cup-shaped crown; -low, pubescent or hirsute herbs with broad, petioled leaves; involucre double, consisting of 5 leafy outer, and as many firm inner bracts as there are rays; disk-flowers each with a bractlet; achenes flat, each adnate to its bract. - - - Chrysogonum

C. Virginianum. Plant stoloniferous; leaves oblong to oval, serrate or crenate, at first radical; heads few or single; with about 5 light-yellow rays. Flatwoods. Spring.

29. Leaves alternate or basal; heads solitary or corymbose; pappus obsolete or of 2 caducous awns;--herbs with the leaves toothed or pinnatifid; bracts of the involucre in about 3 rows, and receptacle chaffy; ray-flowers 5-12, yellow. - $\quad-\quad$ - Berlandiera

B. pumila (tomentosa). Simple or sparingly branched, grayish-tomentose; leaves oblong to oval, crenate; achenes ciliate. Sandy soil. Summer and Fall.

B. humilis. Acaulescent, tomentose; leaves oblong to ovate, crenate or pinnatifid near the base; scapes simple or corymbose above; achenes woolly. Pine-land. Spring to Fall.

B. subacaulis. Tufted, hispidulous; leaves chiefly basal, sinuate or lyrate pinnatifid, oblong or oblanceolate; achenes somewhat ciliate. Sand. Spring to Fall.

30. Receptacle fimbrillate to naked;-herbs with alternate or basal leaves, entire, toothed or pinnatifid; heads long-peduncled; bracts of involucre in 2-3 rows, broad, at least the outer row spreading; receptacle convex; rays mostly neutral, yellow or purple or both; disk-flowers perfect and fertile; pappus of 6-12 awns which are membranous at the base. Spring to Fall. - Gaillardia

G. lanceolata. Brownish-pubescent, loosely branched; leaves spatulate to linear, mostly sessile; rays yellow, disk purple; receptacle almost naked. Sandy pine-land.

G. pulchella, var, picta, with comspicuous ligules; receptacle firmbrillate. Cultivated.

30. Receptacle chaffy throughout, - - - - - - - - - 31

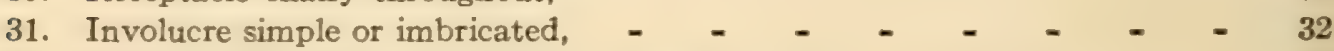

31. Involucre double; pappus 2 or 4 awned, - $\quad$ - $\quad$ - $\quad$ - 33

32. Pappus a cup-shaped border, or $2-4$ short teeth, or absent; - herbs with alternate, toothed or pinnatifid leaves; heads showy, terminating the stem or branches; involucre imbricated, bracts in 2-more rows; disk-flowers perfect and fertile. - Rudbeckia, Cone-flower

R. laciniata. Stems smooth, usually branched; leaves from pinnately 3-7 foliate below, to toothed or entire at the top of the stem, petioled or sessile; 
rays yellow, dronping: disk greenish-yellow; pappus a 4-toothed or entire crown. Swampy ground. Summer and Fall.

R. heterophylla. Stems puthescent, sparingly brancherl; Inwer leaves pinnately 3-5 parted, to upper leaves ovate. coarsely toxthed, all petioled; rays yellow, drooping at last; disk greenish yellow; pappus a cup-shaped border. Swamps. Summer.

R. hirta. Stems hirsute, usually bracted; leaves elliptic to oblong, with winged petioles, or the upper leaves sessile; rays yellow or orange, disk purplish brown; pappus absent. Dry soil. Summer and Fall.

32. Pappus of 2 awns or scales, early deciduous; - herbs with alternate or opposite, simple leaves, and conspicuous heads; bracts in several rows; rays yellow; disk brownish, yellowish or dark purple, forets perfect and fertile. Summer and Fall. - Helianthus, Sunfluwer

H. angustifolius. Scabrous perennial, 6-19 dm., branched; leaves few, alternate, linear, sessile; bracts linear; rays 12-18, disk purple. Moist soil.

H. divaricatus. Perennial, 3-12 dm., smooth or glaucous, simple or with slender branches above; leaves opposite, lancenlate or ovate-lanceolate, entire or serrate, mostly sessile; bracts lanceolate; rays 7-15, disk yellow. Open woods.

H. radula. Hispid or hirsute; simple or branched at the base; leaves few near the base, suborbicular or rhombic; ray-flowers few, minute or wanting; disk purple. Low pine-barrens.

H. Floridanus. Sparingly pubescent, 1-2 m., branched above; leaves lanceolate to linear; disk purple. Sandy soil. Throughout the year.

H. annuus. Pubescent annual, 1-2-3 m. tall, branched above; leaves mainly alternate, broadly ovate, toothed; bracts ovate to oblong. Cultivated and escaped in sandy soil.

33. Awns hispid downward,

33. Awns hispid upward; -herbs with entire or pinnately divided leaves, and heads at the end of the peduncle-like branches; rays commonly 8; disk-flowers perfect and fertile; pappus of 2 awns or scales, - - - - _ _ - - Coreopsis, Tickseed

C. lanceolata. Glabrous, branched; leaves chiefly below, opposite, petioled. spatulate to linear-oblanceolate; rays 3 -lobed at the apex. the midile-lobe notched. yellow; disk yellow; pappus a pair of small fimbriate scales. Dry soil. Spring and Summer.

C. angustifolia. Smonth, 4-angled, branched above; leaves opposite, the lower petioled, oblancenlate, the upper sessile, linear, or mere scales; heads small. corymbose; rays 3-toother, yellow; disk dark purple; pappus a pair of awns. Wet pine-land. Summer and Pall.

C. gladiata. Glabrous, branched above; leaves mostly alternate; the lower ones elliptic-oblung to lancenlate, petioled; the upper sessile, reduced to scales; rays yellow, disk purple; pappus a pair of slender awns. Low pinebarrens. Pall.

C. nudata. Smorth, slender, branched above; leaves alternate, rush-like, the upper minute; rays pink to purple. 3-toothed; disk yellow; pappus a pair of minute awns. Wet pine-land. Spring and Summer.

C. Drummondii, Brown-eyed Susie. Pubescent; leaves pinnately divided rays yellow with purple base, unequally 5-toothed; disk dark purple. Cultivated and escaped. Often with the inner row of the invulucre colored; and sometimes with pistil and stamens in the ray-flowers. Summer.

3. Achenes beakless; - herks with chiefly opposite leaves and numer- 
ous heads; disk-flowers perfect and fertile; rays yellow or white; pappus of 2-4 rigid barbed awns or teeth, or absent.

Bidens, Beggar-ticks, Bur-Marigold

B. bipinnata. Stem tall, slender, 4-angled, branched; leaves bipinnate; heads small; rays $2-3$, yellowish white; achenes $3-4$ awned. Cultivated ground. Summer and Fall.

B. leucantha. Stem 4-angled branched; leaves pinnately 3-5 divided, segments crenate-serrate; rays about 5, cuneate, 2-3 lobed, white; achenes 2-4 awned. Roadside. Through the Winter.

B. laevis (chrysanthemoides), Water-chrysanthemum. Stem branched, slender, ascending; leaves elliptic-lanceolate, obscurely serrate, often connate; heads showy, erect later nodding; rays large, golden yellow, disk orange, achenes 2-4 awned. Borders of lakes and ponds. Fall.

34. Achenes beaked;-tall, smooth annuals with the leaves opposite, entire. lobed or 2-3 pinnately divided; heads peduncled, with yellow disk and crimson, pink, white or yellow rays. Cultivated. - - - - - - - - - Cosmos

The so-called Black Cosmos, C. diversifolius, has red disk and dark red or purple rays.

\section{Cichoriaceae, Chicory Family.}

Scapose or caulescent herbs with alternate or basal, simple leaves and ligulate, perfect flowers in heads, the latter peduncled, rarely sessile; involucres of 1-several rows of bracts; pappus of scales, hairs or bristles; anthers connate around the style; ovary 1-celled, with solitary ovule; stigmas 2 ; fruit an achene.

1. Pappus scaly or bristly, or both, - - - - - - - - 2

1. Pappus of hair-like bristles, achenes smooth or ribbed, - $-\quad-\quad 3$

2. Flowers yellow;-leaves chiefly basal, pale green or glaucous; heads terminating the peduncle-like stems; bracts in 1-2 rows, equal; receptacle flat, naked; pappus double, the outer series of thin scales, the inner of slender bristles.

Adopogon (Krigia), Dwarf Dandelion

A. Carolinianus (K. Virginica.). Leaves spatulate to linear in outline, deeply pinnatifid; scapes erect or ascending; heads yellow. Dry soil. Early Spring to Summer.

A. Virginicus (K. amplexicaulis). Leaves spatulate to oval, of ten narrowed into winged petioles; stem-leaves small, sessile or clasping; heads reddish orange. Around ponds. Spring to Fall.

2. Flowers blue;-involucre double, the outer of 5 leafy scales, the inner of about 8 linear ones; receptacle chaffy to naked, - Cichorium, Chicory

C. Endivia, Endive. Basal leaves sinuate or pinnatifid, cauline leaves auricled; heads $3-5$, axillary. Cultivated.

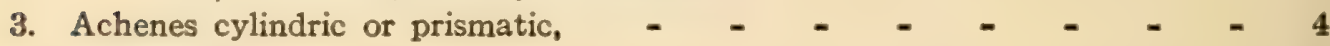

3. Achenes flat - - - - - - - - - - - 6

4. Flowers yellow, - - _ - - - _ - - - - 5

4. Flowers not yellow; - herbs with smooth, rigid, filiform leaves and solitary showy heads; involucre of $5-8$ bracts with several very 
small bracts around; receptacle flat, naked; pappus of copious white hairs.

L. aphylla. Stems erect, simple or forking abnve; leaves reduced to scales, or a few linear leaves at the base; fowers rose-colored to white; achenes nearly as long as the pappus. Dry pine-land. Spring to Fall.

5. Achenes beakless; - herbs with alternate, entire or toothed leaves, sometimes all basal; heads in corymbs or panicles, or solitary: inner row of involucre consisting of 1-3 series of narrow bracts surrounded by outer bracts, abruptly or gradually smaller; receptacle naked or nearly so, flat; pappus tawny or white. Sandy soil. Summer and Fall. - _ _ _ - Hieracium, Hawk-Weed

H. Gronovii. More or less hirsute, tall; stems branched ahove, leafy below; leaves spatulate to oblong, narrowed into winged petioles below and oval to obovate, small and sessile, higher up.

H. Floridanum. Stems more or less hairy, widely branched above, and copiously leafy; leaves pubescent, oval-oblong below, ovate above, sessile.

5. Achenes beaked;-heads long-peduncled; involucre double; the inner row of several narrow bracts, the outer of several series of smaller bracts; receptacle naked, flat; pappus brownish, of copious hairs surrounded by a ring of shorter hairs.

Sitilias (Pyrrhopappus), False Dandelion

S. Caroliniana (P. Carolinianus.) Leaves pinnatifid to denticulate; heads at the end of the smooth stem or peduncle-like branches. Dry soil. Spring to Fall.

6. Achenes beakless;-succulent herbs with alternate, mainly clasping leaves, the edges and midvein often prickly; heads in corymbose panicles, yellow; bracts of the involucre in several rows, unequal, herbaceous or membranous; receptacle tlat, naked; pappus of numerous soft white hairs. Waste places. Spring to Fall. - - - - - - - - Sonchus, Sow Thislle

S. oleraceous. Lower leaves lyrate-pinnatifid, petioled; upper leaves shorter, runcinate or lyrate-pinnatfid; clasping by acute bases.

S. asper. Leaves spatulate to oblong, the upper clasping by rounded bases.

6. Achenes beaked;-tall herbs, often paniculately hranched above, with rather small but often numerous heads of white, yellow or blue flowers; inner involucre of 1-2 series of nearly equal bracts, surrounded by several series of smaller bracts; receptacle flat. naked,

I. graminifolia Laves linear or linear-lanceolate, all entire or the lowest pin natifid; beak of achene shorter than the body; flowers purple or blue, rarely yellowish or white. Open ground. Spring to Fall.

L. Canadensis. Basal leaves petioled, spatulate or oblong, dentate or pinnatifid; stem-leaves sinuate-pinnatifid; beak of achene fully as long as the body; flowers yellow. Open ground. Summer and Fall.

L. sativa, Garden Lelluce. Flowers white; cultivated. 



\section{GLOSSARY.}

It is for our purpose sufficiently accurate to count:

$$
\begin{aligned}
& 1 \text { meter }\left(\mathrm{m}_{0}\right)=39.37 \text { inches. } \\
& 1 \text { foot }=3 \text { decimeters }(\mathrm{dm} .) \\
& 1 \text { inch }=2.5 \text { centimeters }(\mathrm{cm} \text {.) } \\
& \text { or }=25 \text { millimeters (mm.) }
\end{aligned}
$$

Acaulescent: with little or no stem above ground.

Accrescent: growing after flowering, said of calyx, bracts, etc.

Adnate: united, applied to unequal parts.

Aestivation: arrangement of the flowers in a flower-bud. Each part of the perianth (sepal or petal) may be flat or folded or rolled as a leaf in the leaf-bud (see Vernation). Considered collectively the following terms are used:

valvale, when the parts of the perianth meet each other by their mangins without overlapping;

iuduplicate, is valvate with the margins of the parts rolled or bent inward;

reduplicale is valvate with the margins of the parts rolled or bent outward; comlorled or convolule, when each part of the perianth overlaps its neighbor all in the same direction, so that one edge of each part is exterior and the other edge is interior or overlapped.

imbricaled, when one, or more of the parts, is wholly exterior, overlapping

Alate: winged. two others by both its mangins.

Alveolate: pitted, honey-combed.

Amplericaul: applied to leaves with the base-lobes clasping the stem.

Anther (see Stamen): its position in regard to the flament may be innole, erect on the top; adnase, attached to the side; versalile, attached by a point in the back to the top of the filament;-introrse, with the line of dehiscence toward the pistil; extrorse, with the line of dehiscence toward the corolla.

Apex: free termination of a leaf or its segments. It may be acuminate, long and tapering: cuspidale, abruptly contracted to a sharp point; mucronate, tipped with a spiny point; accule, pointed; obluse munded; truncale, cut square off; reluse, slightly depressed; emarginale, with a small notch; obcordale, with a deep indentation.

Areolate: with net-like markings, areolae.

Aril: appendage covering the seed partially or totally.

Aristate: tipped with a bristle.

Baccate: berry-like.

Burbed: with rigid pointa, usually reflexed.

Bifd: two-cleft.

Bloom: a thin bluish or grayish coating on the surface of some fruits or leaves.

Bract, Bractlet: reduced or modified leaf subtending a flower or growing upon the pedicel. 
Bud: contains the rudiments of the future leaf or twig, leafbud, -or those of the future flower, flower-bud, -or of both, mixed bud.

According to their position on the ste $\mathrm{m}$ or branch buds are: terminal or lateral, and the latter ones may be axillary; accessory, close to the axillary; or adventitious, on any other part of the plant.

According to their covering buds are scaly or naked.

According to the time of their development buds are active or latent.

(See Aestivation and Vernation).

Bulb: a subterranean bud, with concentric layers enclosing all within it, tunicated;or with fleshy scales arranged spirally, scaly.

Bulblet: small bulb, usually above ground on the stem.

Caducous: dropping off very early, especially used for petals and sepals.

Calyx (see Flower and Perianth); outer whorl of the floral envelope. May have its sepals distinct, polysepalous-or more or less united, mono- or gamo- or synsepalous.

Canescent: hoary from a gray pubescence.

Capitate: growing in heads or in dense clusters.

Carpel: a leaf, modified so as to bear ovules; applied to a simple pistil or to one of the leaf components of a compound pistil.

Caruncle: a small protuberance near the hilum of the seed.

Caudex: trunk of palms and tree-ferns; also the perennial rootstock of an annual plant.

Caulescent: having an aerial stem.

Cauline: belonging to the stem, chiefly used of leaves.

Chaffy: consisting of dry or membranous scales or bracts.

Ciliate: fringed with hairs.

Cinereous: ashy gray.

Circinate or Circinnate; coiled inward from the top.

Cladophyl: leaflike branch of a filiform stem.

Cleistogamous, Cleistogene: used for flowers which do not open, as a means of selfpollination.

Cluster: several flowers or fruits growing close together.

Coma: a tuft of hairs on a seed.

Connate: said of two opposite sessile leaves with the bases united.

Connivent: coming together, converging.

Coriaceous: leathery.

Corm: a solid, bulb-like, underground expansion of a stem, with a leaf-bud at the summit or at the side.

Corolla (see Flower and Perianth): inner whorl of the floral envelope. May have its petals distinct, polypetalous;-or more or less united, mono- or gamoor sympetalous; in the latter case the unison may be restricted to the claws, forming a tube, or extended to the laminae of the petals, forming the border or limb.

Covering: the surface of a leaf, stem, etc., may be:

glabrate, nearly smooth, or becoming smooth with age;

glabrous, without covering, smooth;

muricate, rough, with short, hard points;

rugose, wrinkled;

scabrous, rough, with minute hard points;

scurfy, with bran-like scales;

sulcate, grooved;

verrucose, covered with warty elevations; 
Or the surface may be covered with hairs. prickles or spines, and is called: aculcale, prickly:-conescent, hoary with a gray pubescence; echinale. beset with prickles;-floccose, hairs in soft fleecy tufts; - hirsule hairs long, rather stiff, scattered;-hispid, hairs short, stiff, scattered;-lanuginose, woolly;-pilose, hairs short, soft, scattered;-puberulent, minutely hairy; - pubesiems, hairs short, soft, dense;-sericeous, hairs silky. dense;--selose, or selaceous, bristly;-spinose, beset with spines;-strigose. strigillose, hairs rigid, dense, appressed;-tomenose, like felt; - villous, hairs soft, long, dense.

Cucullate: hooded or rolled up into hood-shape.

Deciduous: not evergreen, dropping off.

Decurrent: applied to leaves which are prolonged down the side of the stem below the point of insertion.

Decussate: applied to opposite leaves when the successive pairs each stand at right angles with the pair next below them.

Dehiscence: opening of anthers or fruit by valves (valvular), by pores (porous), by a lid at the top (circumscissile or opercular), etc.-Valvular dehiscence of fruit may be;

sutural, along the sutures of a 1-celled pericarp;

loculicidal, each carpel opens at its dorsal suture, the partitions remaining attached to the middle of the valves;

septicidal, the carpels separate along the partitions, and each carpel may dehisce suturally or remain indehiscent;

septifragal, the carpels break away from the partitions, the latter remaining united in the axis.

Dichogamous: the condition of a perfect flower in which the stamens and pistils are not mature at the same time, so that self-fertilization is prevented.-The opposite condition is called homogamous.

Dichotomous: forked; divided into two equal branches.

Didymous: double, occurring in pairs.

Diffuse: widely spreading.

Dimorphous, used of plants possessing two forms of flowers, one with short styles and long stamens, the other with long styles and short stamens; also used of the flowers.

Dissepiment: partition; the separating membrane (double) in a compound ovary or in fruit.-It is called folse when the partition is single.

Distichous: arranged in two rows; two-ranked.

Ear: the inflorescence of a cereal grass.

Epiphyte: a plant that grows upon another plant but does not derive its food from it.

Evanescent: of short duration.

Exserted: as stamens protruding from the tube of a corolla.

Exstipulate: without stipules.

Extrorse: facing outward; applied to anthers which face away from the pistil.

Falcate: in the shape of a sickle or scythe.

Ferruginous: rust-colored.

Filiform: slender, thread-like.

Fimbriate: fringed; the margin bordered with slender processes.

Fleruous: bent from side to side; rigzag.

Flower: consists of four whorls of leaves, viz, calyx (sepals), corolla (pelals), andracium (stomens), and synacium (pistils); one or more of the whorls may be abeent. 
Flowers are said to be:

complete: the whorls all present, each of 1-more series or rows;

diacious: flowers either pistillate or staminate, borne on different plants;

distinct (opposite of coherent, connate): parts of the same whorl not united; epigynous: sepals, petals and stamens seem to arise from the upper part of the ovary;

fertile: producing fruit; or if said of stamens, possessing pollen; often used as synonymous with pistillate;

free (opposite of adherent, adnate): parts of two adjacent whorls not united; hypogynous: sepals, petals and stamens inserted below the ovary;

monæcious: flowers either pistillate or staminate, borne on the same plant;

neutral: both stamens and pistils absent;

perfect: both stamens and pistils present in the same flower;

perigynous: sepals, petals and stamens arise from the rim of an urn-like outgrowth of the receptacle which surrounds the pistil;

pistillate: stamens absent;

polygamous: some flowers on the plant are imperfect;

regular: having the parts of the same whorl similar and alike;

staminate: pistils absent;

sterile: not producing fruit; or if said of stamens, not possessing pollen or anthers; often used as synonymous with staminate: some flowers in the Compositæ (Carduaceae) however are perfect, yet produce no fruit;

symmetrical: having the same number of organs in each whorl.

Frond: the leaf of a fern;-pinnc: are primary divisions of fronds, pinnules are sec. ondary pinnae.

Fruit: consists of a seed or seeds (ripened ovules), - and the pericarp (carpels), often with adhering parts of the former flower.

An accessory fruit is a fruit with the receptacle or the other parts as an important part of the whole.

An aggregate fruit consists of a mass of single fruits, all the product of a single flower.

The principal fruits are:

a. Indehiscent.

achene, small dry pericarp free from the single seed;

berry, succulent pericarp with seeds loosely in the pulp;

caryopsis, same as grain;

drupe or stone-fruit, three-coated, one-seeded;

etaerio, numerous small drupes united to each other or to the receptacle (aggregate fruit);

glans, same as nut, sometimes with a persistent involucre called cupule; grain, thin dry pericarp adherent to the single seed;

hesperidium, many-carpeled pericarp with the rind more or less easily separable from the pulpy mass within;

key, same as samara;

nut; hard dry pericarp, 1-more seeded;*

pepo, fleshy pericarp with hardened rind and many seeds on parietal placentae;

pome, pericarp, consisting of the permanent calyx and the fleshy receptacle, seeds contained in several cartilaginous or bony cells;

samara, dry with winged appendages (alate);

tryma, a 2-coated drupe;

utricle, small, thin pericarp loosely upon the single seed.

*The Brazil-nut or Nigger-toe is the seed of Bertholletia excelsa of the Family Myrtaceæ. 


\section{GLOSSARY.}

\section{b. Dehiscent.}

copsule, dry and opening by as many or twice as many valves as there are carpels, or by pores;

follicle, a single 1-celled, many-seeded carpel opening by ventral suture;

legume, a single 1 -celled carpel with many seeds in 1 row dehiscing into 2 valves;

lomenl, a jointed pod which separates transversely into 1-seeded segments;

pod, same as legume and siligue;

pyxis, dry and many-seeded, opening by a lid;

regme, with dehiscent carpels separating elastically;

silique, 2-carpeled, 2-celled by false dissepiment, 2-valved with 2 parietal placentæe. silicle, a short silique.

Pruits involving many pericarps or a whole flower-cluster are:

cone or strobilus of the Gymnosperms and some Pteridophytes, a mass of im-

bricated scales;

cone or syncarpium of the Magnolia, closed pericarps on a lengthened torus; sorosis, the whole flower-cluster becoming a mass of united pericarps (mulliple f ruil):

syconium, numerous achenes enclosed within the hollow fleshy receptacle.

Fugacious: soon dropping off, or fading.

Fulvous: tawny or dull yellowish brown.

Gibbous: swollen on one side.

Gland: a small protuberance secreting a liquid.

Glaucous: with a bloom or powdery, when whitish or light bluish-green.

Glumaceous: resembling glumes or bearing glumes.

Glumes: the outer husks or chaffy bracts in the inflorescence of the Grasses.

Gyandrous: said of stamens when united with the style.

Habitat: place of growth of a wild plant, as terrestrial, aqualic, epiphylic, etc.

Horn: a tapering appendage.

Husk: the dry outer covering of some fruits;

Hyaline: colorless translucent.

Hybrid: plant produced by crossing of two species.

Imbricate: overlapping like the shingles on a roof.

Indehiscent: said of a pericorp (or fruil) which does not open to liberate the seeds.

Indusium: a delicate flap arising from the epidermis of a frond and covering a sorus of a fern; the inrolled margin of a frond protecting the sori alongside, is called false indusium.

Inflorescence: a definite region of a plant set apart for the production of flowers; -the term is also used to indicate the groups in which the flowers are ar. ranged on the plant. Two types are often mentioned, viz:

a. Centripetal, with the older flowers at the base or at the circum. ference of the group.

spike, with slender rachis and sessile flowers;

spadix, with thick fleshy rachis and sessile or imbedded flowers;

ament or calkin, a slender, often drooping spike with unisexual flowers subtended by bracts;

raceme, erect or drooping rachis with lowers on pedicels from different points of the rachis:

corymb, same as receme, but flat-topped or convex through the greater length of the lower pedicels;

umbel, much like the corymb, but the pedicels come from the same point of the rachis;

head, a reduced umbel with the fowers (forets) sessile upon the torus; 
ponicle, a compound raceme through branching of the pedicels; thyrse, a dense mostly pyramidal panicle.

b. Centifrugal, with the older flowers at the top or at the centre of the group,

cyme, a flat or convex flower-cluster resembling a corymb; when flat-topped it is a fastigiate cyme; when loosely spreading it is a cymose panicle; when rounded it is a globose cyme; when resembling a coiled raceme through one-sided development, it is a scorpioid cyme;

fascicle, a crowded cyme, the flowers being nearly sessile;

glomerule, an axillary cluster;

verticillaster, a pair of glomerules in the axils of two opposite leaves, and meet. ing around the stem of the plant.

Inserted: attached to an organ or growing from it.

Internode: the portion of a stem between two nodes.

Introrse: facing inward; applied to anthers which face towards the pistil.

Involucre: bracts collected into a whorl or in spiral rows, subtending a flower or an inflorescence;-involucel is a small or a secondary involucre.

Laciniate: provided with an irregular and deeply cut fringe;

Latent: dormant, inactive, applied to buds.

Latex: the milky juice of some plants.

Leaves: a leaf consists of the blade or lamina and the petiole; absence of the petiole makes the leaf sessile; absence of the blade with a flat compressed petiole makes the leaf a phyllodium.

Leaves are classified as follows:

A. simple leaves.

1. pinnately-veined:

a. lower veins longest: linear, lanceolate, ovate, deltoid;

b. middle veins longest: oblong, elliptic, oval, orbicular;

c. upper veins longest: oblanceolate, obovale, cuneate, spatulate;

d. lower veins curved: cordate, auriculate, hastate, sagittate;

e. tissue deficient between the veins to halfway the midvein: pinnatifid, runcinate, lyrate;

f. tissue deficient between the veins to near the midvein: pinnately-pdrted, sinuate;

2. palmately veined: reniform, peltate, palmately-lobed, pedate, flabelliform or fanshaped.

3. parallel-veined: linear, ensiform or sword-shaped;-lanceolate and other forms of a. b. c. d.;-contracted forms as acerose or needle-shaped, subulate or awlshaped, scaly, etc.

4. forked-veined (dichotomous) in Pteridophytes.

B. compound leaves.

1. pinnately compound:
a. one-foliate, if only one leaflet is articulated to the petiole;
b. two-foliate or binate, with two leaflets on the petiole;
c. tri-foliate or ternate, with three leaflets on the petiole;
d. even-pinnate or equally pinnate or abruptly pinnate;
e. odd-pinnate or unequally pinnate;
f. interruptedly pinnate, if smaller pairs occur between the larger ones;
g. bi-pinnate or twice pinnate; bi-ternate;
h. tri-pinnate or thrice pinnate;
i. decompound, if the divisions go still further.

2. palmately compound: ternate or 3-foliate, quinate or 5-foliate, septenate or 7-foliate. The margin of a leaf may be entire, and it is said to have a hem when a vein runs 
along the whole margin; - or the mangin may be dentale with teeth directed straight outward, serrabe with teeth pointing forward, crenole with rounded teeth and sharp sinuses, undulale with both teeth and sinuses rounded; when the margin is irregularly and sharply cut into, it is said to be incised or cul, laciniale or torn and crose or jagsed;-when the margin is wavy up and down it is called repand, or if there is very much tissue in the margin it is crispale or crisped;-projecting veins make the margin spinous.

Lenticular: double convex.

Ligule: the strap-shaped corolla of some Composita;- a membranous appendage at the junction of leaf-blade and sheath in Grasses.

Locule: compartment of a compound ovary.

Midrib: the large central vein of a leaf.

Monandrous: having only one stamen.

Moniliform: like a string of beads.

Nerve: a slender unbranched vein; or the term is used instead of vein or rib.

Node: the point on a stem which normally bears the leaf or leaves.

Obsolete: much reduced or only rudimentary.

Ocrea: the two stipules when forming a tubular sheath around the stem or petiole.

Ovary: (see Pistil).

Ovules: an ovule consists of the nucellus, with the embyro-sac or megaspore inside, and covered outside by the integument, a membrane which projects beyond the apex of the nucellus, leaving a passage called foramen or micropyle. In the seed the integument has become a hard covering, the testa, sealing up the structures within.-The ovule is supported on a stalk, the funiculus; the juncture of nucellus and funiculus is the chalaza. When the ovule stands straight upon the funiculus, the former is said to be orthotropous. When completely inverted it is anatropous, and when partly inverted it is amphiIropous; in those two positions the funiculus becomes adherent to the testa making a longer or smaller seam, called the raphe. When the ovule is curved upon itself, it is campylolropous; and no raphe is formed.-The eye or scar left on the seed by the separation from the stalk is the hilum.

As to the position of the ovules in the ovary, they grow erect, ascending. horisonlal, pendulons or suspended.

Pales (Palet): the bractlets at the base of the flowers in the spikelet of a grass;-or the chaffy scales on the receptacle of some Composita; - also applied to the flattened brown hairs or chaff found on the stems and leaves of Ferns.

Pappus: the calyx of the florets of Composita; it consists of a tuft of hairs.-or of tooth-like often barbed processes, or plumose bristles, - or a cup, -or a row of scales.

Pectinate: like the teeth of a comb.

Pedate: palmately parted, with the lateral segments cleft.

Peduncle: Bower-stalk.

Pellucid: transparent or translucent.

Peltate: shield-shaped, attached by its under surface.

Perfoliate: applied to an amplexicaul leaf when the base-loles have grown together, so that the stem seems to pass through the blade.

Perianth: is the name for calyz and corolla collectively, or for the floral envelope if only one is present; if the perianth is absent. the flower is called naked or achlamydeous. - The principal forms of perianth are:

a. the parts distincl:

crucifcrows, four long-clawed petals standing in opposite pairs; 
caryophyllaceous, five long-clawed petals with spreading laminae;

rosaceous, five short-clawed petals, spreading;

liliaceous, six perianth-leaves, gradually spreading;

papilionaceous, page 69 ;

orchidaceous, page 40.

b. the parts more or less united;

cup-shaped, tube very short and border concave;

wheel- or-star-shaped (rotate), tube very short and border flát;

urn-shaped (urceolate), oblong or globular, border contracted;

bell-shaped (campanulate), tube with rounded base, border spreading;

salver-form, tube narrow, abruptly passing into a spreading border;

funnel-form, tube narrow, gradually widening into a border;

tubular, tube narrow with a small border or rim;

strap-shaped (ligulate), tube as if split open lengthwise and flattened, border represented by teeth;

lip-shaped (labiate), tube widening and ending in a 2-lipped border; the corolla has a 2-lobed upper lip and 3-lobed lower lip; if the calyx is also labiate the position of the lips is reversed.-A labiate corolla is galeate when the upper lip is concave (helmeted); it is personate when the juncture of tube and border (called the throat) is narrowed by a palate; it is ringent or gaping when the throat is wide open.

Pericarp: the wall of the fruit, sometimes the whole fruit.

Petals: parts of the Corolla.

Petiole: leaf-stalk.

Phyllodium: a leaf with flat, expanded petiole and no blade.

Pistil: a leafy structure of the Angiosperms, composed of:

the ovary, which consists of one or more carpels containing the ovules or megasporangia,

the style or styles, which may be absent, and

the stigma, the receptive surface for the pollen; it is called sessile when the style is absent. Styles and stigmas may be more or less united.

The ovary is simple, -or compound, i. e. containing one or more cells or locules,-or multiple, when several simple ovaries are united. As to position, the ovary may be superior (free from the calyx), when perianth and stamens are inserted below,-or inferior (adnate to the calyx), when those other parts of the flower are inserted above the ovary.

Placenta: the place within the ovary-cell where the ovules are attached.-Placentae may be sutural or ventral,-axial or central in some 1-celled compound ovaries,-or parietal, i. e. on the wall of the cavity.

Pollinia: masses of coherent pollen.

Pollen: (see Stamen).

Praemorse: as if bitten off.

Punctate: marked with pits, translucent glands, or colored dots.

Pungent: sharp to taste or smell.

Putamen: the shell of a nut; also the stone of a fruit.

Rachis: the axis of an inflorescence; also the main-rib of a frond, or of a compound leaf.

Raphe: (See Ovules).

Receptacle: (see Torus).

Reticulate: netted.

Rhizome or Root-stock: a fleshy rooting stem, wholly or partially underground, often 
scaly or marked with scars of former leaves, and producing new shoots annually, chiefly at the apex.

Root: a hollifast, or an absurhent organ of the plant, or both.

Accurding to their places, routs are: suib-routs; waler-rools; air-roots; adventilious rools.

According to their functions, roots are: feeding rools; clinging rools; prop-rools.

According to their shape, roots are of two types:

a. axiul. having a main body continuous with the stem at the collum or neck, viz:

ramous or lap-rool, extensively branching:

fusijorm or spindle-shaped rook, tapering downward and for a short distance upward.

conical rook, tapering downward, beginning at the collum;

nupiform or turnip-shaped rool, often broader than long.

b. diffuse, dividing up into long, slender roots of nearly equal size, without a main root, viz:

fibrows rools, with thread-like divisions;

fasciculate rools, with some of the fibres fleshy;

nodulous rools, when the fibres have irregular thickenings;

moniliform or necklace-rools, with regular enlargements on the fibres.

Rufous: tawny, yellowish red.

Runner: A stem or branch that creeps along the ground, rooting at intervals.

Scape: a leafless flower-axis arising from the root.

Scapose: bearing a scape, or resembling a scape.

Scar: the mark left upon a stem or a branch by the separation of a twig or a leaf.

Scarious: dry, thin and colorless, membranous.

Seed: (see Ovules).

Sepals: parts of the Calyx or Perianth.

Sorus (plural Sori): a fruit-dot, or cluster of sporangia on Ferns.

Spathe: a large bract, sometimes a pair of bracts, partially enclosing or covering a flower or an infloresence.

Sporangium: a special cell producing or containing spores.

Spore: a cell set apart for reproduction.

Spur: a hollow pointed or sac-like appendage.

Squarrose: with spreading processes.

Stalk: a lengthened support of a part of a plant.

Stamen: the leafy structure of the Angiosperms bearing the pollen (microspores).

A stamen consists of the flament and the anther, the latter composed of two pollen-sacs (microsporangic); the portion of the filament which connects the two parts of the anther is the connectile or conneclive.-A stamen without anther is a staminodium.-Stamens are called:

monodelphous, when united by their filaments into 1 bundle;

diadelphuus, when so united into 2 sets, either of the same or of different numbers.

polyodelphous, when so united into several sets;

syngenesious, when united by their anthers;

dodynumous, when 2 are long and 2 shorter in the same flower:

coridymomous, when 4 are long and 2 shorter in the same flower.

Stellate: radiating from a point. slur-shaped.

Stem: the axis or man borly of a plant. It is called coulis in herbs, culm in grasses and seclges, trunk in trees, cundex in palms and tree-ferns, sluck or caudex in the cactus, vine in climisng and trailing plants. - Scale-bearing. mostly 
subterranean stems are called root stock- or rhizome, or when short and as if bitten off, pramorse root; when possessing eyes or latent buds they are tubers; covered with thin scales on the very much condensed internodes, the almost globular stem is called a corm, and if the scales are fleshy we speak of a bulb, either tunicated or scaly, - As to the direction in which the leafbearing stems grow, they are distinguished by the names; erect;-procumbent, prostrate or trailing;-decumbent or reclining;-assurgent or ascending, when growing obliquely from a longer or shorter prostrate base.

Stipe: the stalk of the ovary lifting it above the insertion of the other floral organs;also the leafstalk of a fern-leaf.

Stipules: a pair of appendages at the base of the petlole:-the stipules of a leaflet are called stipels.

Stolon: a branch which bends over and strikes root (compare Runner); a long and slender stolon is called sarment.

Striate: marked with fine longitudinal grooves.

Style (see Pistil).

Subulate: awl-shaped.

Succulent: juicy, of loose cellular structure, fleshy.

Sucker: an ascending or erect branch from a creeping underground stem.

Suffrutescent: slightly woody at the base.

Suffruticose: under-shrub; a woody base, annually producing herbaceous shoots.

Sulcate: furrowed.

Tassel: the staminate inflorescence of corn.

Tegmen: the inner seed-coat.

Tendril: a leaf or portion of a leaf, or a branch, so modified as to serve the purpose of climbing.

Terete: cylindrical.

Testa: the outer seed-coat.

Torose, Torulose: with constrictions and enlargements at intervals.

Torus or Receptacle: the axis of the flower at the summit of the flower-stalk; from it spring the parts of the flower, or it bears the florets of a head. That portion of the receptacle which is raised into the midst of the whorls is called the disk (hypanthium).

Tuber (see Stem).

Tubercle: a small knob-like outgrowth.

Tumid: swollen;-Tumescent: somewhat swollen.

Turbinate: shaped like a top.

Turgid: swollen, inflated.

Unguiculate: possessing a claw.

Vegetable: an edible herbaceous plant or a part thereof, that is commonly used for culinary purposes; some fruits are excepted as watermelon, cantaloupe, strawberry and peanut.

Veins: strands of vessels forming the frame-work of a leaf.

Venation: distribution of the veins in a leaf.

Vernation: arrangement of the leaves in the bud. A leaf in the bud may be flat or open, $\longrightarrow$ or:

inflexed or reclined, when the upper part of the leaf is folded down upon the lower; conduplicate, when the two halves are folded face to face along the midvein;

plailed or plicale, when folded like a fan;

circinate, when rolled from the apex downward;

convolute, when rolled from one edge to the other; 
involute, when rolled from both edges toward the midvein, inward;

resolute, when rolled from both edges toward the midvein, outward.

The mode of two leaves in the bud coming together is called:

valvase: when the edges meet without overlapping;

imbricale: with edges overlapping; the latter is equilant when conduplicate leaves

alternately embrace; obvolute or holf-equilant when the outer leaf embraces

only one of the mangins of the inner leaf; and triquetrous when the leaves are equitant at each angle of a triangular bud.

Vesicle: a diminutive air-vessel or bladder.

Virgate: straight and slender, wand-like.

Weed: a plant which grows where it is not wanted and is troublesome. 



\section{INDEX.}

Abelia, 137

Abutilon, 90

Acacia, 67

Acalypha, 82

Acanthospermum, 150

Acanthus Family。 130

Acer, 87

Aceraceae, 87

Aceratus, 117

Achroanthes, 42

Acrida, 51

Acorus, 29

Acrostichum, 20

Adder's mouth, 42

Adder's tongue, 19

Adianthum, 20

Adopogon, 152

Aeschynomene, 73

Aesculaceae, 87

Afzelia, 130.

Agave, 38

Ageratum, 144

Agrostemma, 54

Air-plant, 32

Albizzia, 67

Aletris, 38

Alfalfa, 70

Alismaceae, 26

Allamanda, 115

Alliaceae, 34

Alliga:or-pear, 98

Allwnaceace 52

Alium, 34

Aimond, 67

Alecasia, 29

Alpunaceae, 39

Alsinaceac, is

Alsuphilia, 22

Alihaea, 91

Alinglaceac, 63

Alyssum, 59

Amaronth Family, so

Amaryinis Fasuly. 37

Amazon-iniy, 3s

Numbers indicate pages.

Ambrosiaceae, 140

American Aloe, 38

American Centaury, 113

American Ivy, 89

American Lotus, 58

Amianthium, 33

Ammannia, 99

Ammiaceae, 104

Ammocallis, 114

Amorpha, 72

Ampelopsis, 89

Amsonia, 114

Amygdalaceae, 66

Anacardiaceae, 85

Ananas, 32

Anastatica, 60

Anchistea, 21

Andromeda, 107, 108

Angelica, 106

Angiospermae, 9

Anise-tree, 56

Anonaceae, 55

Anredera, 53

Antigonon, 49

Anychiastrum, 52

Apios, 76

Apium, 106

Apocynaceae, 114

Apple Pamily, 65

Apricot, 67

Apteria, 40

Aquifoliaceae, 85

Araceae, 28

Arachis, 76

Araliaceae, 103

Araucaria, 25

Arbor-vitae, 24

Arecaceae, 28

Argemone, 58

A risaema, 23

Aristolochia, 137

Armeniaca, 67

Armeriaceac, 103

Arrow arum, 20
Arrow-root Pamily, 40

Arrowhead, 26

Artocarpaceae, 47

Arum Family, 28

Arundo, 27

Asaraceae, 137

Asclepias, 116

Ascyrum, 92

Ash, 111

Asimina, 56

Asparagus, 35

Aspen. 44

Aspidium, 21

Asplenium, 21

Aster, 148

Asteriscus, 60

Astragalus, 71

Atamasco-lily, 38

Atriplex, 50

Avicennia, 124

Avocado-pear, 98

Azalea, 107

Azolla, 23

Baby-foot, $8 t$

Baccharis, 142

Bachelor's button, 81

Balsaminaceae, 77

Bamboo, 27

Bamboo-vine, 37

Banana, 39

Banana-shrub, 57

Baptisia, 69

Bartonia, 113

Basellaceae, 53

Basil, 126

Batatas, 118

Batodendron, 108

Bauhinia, 68

Bayberry Family. 14

Bay-star vine, 57

Beach-sap, 59

Bean-vine, 76

Bearbersy, 86 
Beard-tongue, 128

Bear-grass, 36

Bedstraw, 135

Beech Family, 45

Beet, 50

Beggar-ticks, 73, 152

Begonia, 97

Bejaria, 107

Bell-flower Family, 139

Berlandiera, 150

Bermuda-grass, 27

Bidens, 152

Bigelovia, 142

Bignoniaceae, 132

Billbergia, 32

Bilsted, 63

Bindweed, 49, 118

Biota, 24

Bird-cactus, 84

Bird's nest Moss, 23

Birthwort Family, 137

Blackberries, 64

Black Bindweed, 49

Black Cherry, 67

Black Cosmos, 152

Black Haw, 110

Black-jack, 46

Black Mangrove, 124

Black Mustard, 59

Black Nightshade, 120

Black-root, 145

Black Sloe, 67

Black Snake-root, 105

Black Walnut, 43

Bladderwort, 132

Blazing-star, 33, 144

Blechnum, 21

Blephariglottis, 41

Bloodwort Family, 39

Blue Beech, 45

Blueberry, 108

Blue-eyed Grass, 39

Blue-flag, 38

Blue-hearts, 129

Blue-jack, 46

Blue Palmetto, 28

Blue-tangle, 108

Bluets, 136

Boehmeria, 47

Boerhaavia, 52

Bog-torch, 29

Boltonia, 148
Bonnets, 58

Borage Family, 121

Borrichia, 149

Boston Fern, 21

Boston Staghorn, 21

Botan Pine, 25

Botrychium, 19

Bottle-brush, 100

Bottle Gourd, 138

Bougainvillea, 52

Bouncing Bet, 55

Boussingaultia, 53

Bowstring-hemp, 36

Box-elder, 87

Bracken, 21

Bradburya, 74

Bradleia, 71

Brake, 21

Brasenia, 57

Brassica, 59

Brassicaceae, 58

Breynia, 82

Bridal-wreath, 64

Bromeliaceae, 32

Broom-rape Family, 132

Broussonetia, 48

Brown-eyed Susie, 151

Brunnichia, 49

Bryophyllum, 61

Buchnera, 129

Buckbean Family, 113

Buckeye Family, 87

Buck-thorn, 110

Buckthorn Family, 88

Buckwheat Family, 48

Bullace Plum, 67

Bumelia, 110

Bunch-flower Fam., 32

Bunya-Bunya Pine, 25

Burmannia, 40

Bur-marigold, 152

Bur-reed Family, 25

Bush-clover, 74

Butneria, 65

Butterfy-lily, 37

Butterfly-pea, 74

Butterfly-weed, 116

Butterwort, 132

Button-ball, 63

Button-bush, 135

Button Snake-root, 105, 144

Button-weed, 135
Cabbage, 89

Cabombaceae, 57

Cacalia, 143

Cactus Family, 96

Cæsalpinia, 69

Cakile, 59

Calabash, 138

Caladium, 29

Calamintha, 126

Calathea, 40

Calla-lily, 29

Callicarpa, 124

Calliopsis (see Coreopsis)

Callistemon, 100

Callitrichaceae, 84

Calophanes, 130

Calopogon, 42

Calycanthus, 65

Calystegia, 118

Camassia, 35

Camellia Family, 93

Campanulaceae, 139

Camphire, 99

Camphor-tree, 98

Campsis, 133

Cannabinaceae, 47

Canna Family, 40

Cantaloupe, 138

Caprifoliaceae, 136

Capriola, 27

Capsicum, 120

Caraway, 106

Cardinal-flower, 140

Cardiospermum, 88

Carduaceae, 141

Carnation, 55

Carpet-weed Family, 53

Carphephorus, 142

Carpinus, 45

Carrion-flower, 36

Carrot, 105

Carum, 106

Carya, 43

Caryophyllaceae, 54

Caryota, 28

Cassava, 84

Cassiaceae, 68

Cassine, 86

Castalia, 58

Castanea, 45

Castor-bean, 83

Catalpa, 133 
Catch-fly, 84

Cat-gut, 71

Cat-tail Pamily, 25

Cayenne-pepper, 120

Ceanothus, 88

Cecropia, 48

Cedar, 25

Celery, 106

Celosia, 51

Celtis, 48

Centella, 104

Centrosema, 74

Century-plant, 38

Cephalanthus, 135

Cerastium, 54

Cerasus, 67

Ceratiola, 85

Ceratophyllaceae, $\mathbf{5 5}$

Cereus, 96

Cestrum, 121

Chaenolobus, 145

Chamaecrista, 68

Chamaecyparis, 25

Chamaelirium, 33

Chamaerops, 28

Chamaesyce, 84

Chaptalia, 149

Chaste-tree, 123

Cheiroglossa, 19

Chelone, 129

Chenille-plant, 82

Chenopodiaceae, 50

Chequered Lily, 35

Cherokee Bean, 75

Cherokee Rose, 64

Cherries, 67

Cherry-laurel, 66

Chickasaw Plum, 67

Chicken-grape, 89

Chickweed Pamily, 54

Chicory Pamily, 152

China Bean, 76

China-berry tree, 80

China Brier, 37

Chinquapin, 45

Chionanthus, 112

Chondrophora, 142

Christmas Pern, 21

Chrosperma, 33

Chrysanthemum, 146

Chrysogonum, 150

Chrysoma, 148
Chrysopsis, 147

Chufa, 27

Cibotium, 22

Cichoriaceae, 152

Cicuta, 105

Cinnamon Fern, 20

Cirsium, 142

Cissus, 89

Cistaceae, 94

Citron, 78, 138

Citrullus, 138

Citrus, 78

Clematis, 55

Clerodendron, 123

Climbing Fern, 22

Climbing Rose, 64

Clinopodium, 126

Clitoria, 74

Clover, 70

Cloves, 35

Club Moss, 22

Cnidoscolus, 83

Coccolobis, 49

Cock's comb, 51

Cocos, 28

Codiæum, 82

Coffee-bean, 72

Cola-nut Family, 91

Coleus, 126

Colic-root, 38

Colocasia, 29

Commelinaceae, 31

Compositae, 18

Comptie, 23

Cone-flower, 150

Coniferae, 23

Conoclinum, 144

Conopholis, 132

Convallariaceae, 35

Convolvulaceae, 117

Coontie, 23

Coprosmanthus, 36

Coral-bush, 75

Coral-honeysuckle, 137

Corallorhiza, 42

Coral-plant, 129

Coral-root, 42

Cordia, 122

Cordyline, 36

Coreopsis, 151

Corn, 27

Cornaceae, 103
Corn-cockle, 84

Cornel, 103

Corrigiolaceae, 51

Cortaderia, 27

Corylaceae, 45

Cosmos, 152

Cotton, 91

Cotton-wood, 44

Cotyledon, 61

Cow-pea, 76

Crab-cactus, 96

Cracca, 71

Crane's bill, 76

Crape-jasmine, 114

Crape-myrtle, 99

Crassina, 149

Crassulaceae, 61

Crataegus, 65

Crested Boston Fern, 21

Criaum, 37

Crocus, 39

Crookea, 92

Crookneck, 139

Crotalaria, 70

Croton, 82

Crotonopsis, 82

Crow-berry Pamily, 84

Crowfoot Family, 55

Crownbeard, 149

Crown-of-Thorns, 84

Crow-poison, 33

Cruciferae, 58

Cucumber, 138

Cucumus, 138

Cucurbitaceae, 138

Cudweed, 145

Cupressus, 25

Cuscutaceae, 118

Cushaw, 139

Custard-apple Family, 55

Cuthbertia, 31

Cyatheaceae, 22

Cycas Pamily, 23

Cyclamen, 110

Cynoctonum, 112

Cynoxylon, 103

Cynodon, 27

Cyperaceae, 27

Cypress, 24, 25

Cypress-vine, 118

Cyrtomium, 21 
Daedalactanthus, 131

Daffodil, 38

Dahoon, 86

Darnel, 28

Dasheen, 29

Dasystoma, 130

Date Palm, 28

Datura, 121

Daubentonia, 71

Daucus, 105

Day-flower, 31

Decodon, 99

Decumaria, 62

Deer-grass, 98

Deer-tongue, 143

Dendropogon, 32

Desmodium, 73

Deutzia, 62

Devil's bit, 33

Dewberries, 64

Dew-flower, 31

Dianthus, 55

Dichondra, 117

Dichromena, 27

Dicotyledones, 11, 42

Diervillea, 137

Diodia, 135

Dion, 23

Diospyros, 110

Dish-cloth Gourd, 139

Dioscorea, 38

Ditch Grass, 26

Ditch Stonecrop, 61

Dock, 49

Dodder Family, 118

Dogbane Family, 114

Dog-fennel, 144

Dogwood Family, 103

Dolicholus, 74

Dombeya, 92

Donkey-ears, 138

Dracaenaceae, 36

Dragon-root, 29

Dragon-tree, 36

Drosera, 60

Dryopteris, 21

Duckweed Family, 29

Duranta, 123

Dutchman's Pipe, 137

Dwarf China-berry, 80

Dwarf Dandelion, 152

Dwarf Palmetto, 28
Dwarf Poinciana, 69

Dwarf Sumac, 83

Easter Lily, 38

Ebenaceae, 110

Ebony Family, 110

Echeveria, 61

Echinocactus, 96

Echinocereus, 96

Echinodorus, 26

Eclipta, 149

Eel-grass, 27

Egg-plant, 121

Ehretiaceae, 122

Eichhornia, 32

Elaeagnus, 97

Elder, 136

Elephantopus, 143

Elm Family, 48

Elodea, 27, 92

Elodeaceae, 26

Elytraria, 130

Empetraceae, 84

Endive, 152

English Rye-grass, 28

Epidendrum, 42

Epigaea, 107

Epilobiaceae, 101

Epiphyllum, 96

Eranthemum, 131

Erechtites, 145

Ericaceae, 107

Erigeron, 146

Eriobotrya, 66

Eriocaulon, 30

Eryngium, 105

Erythrina, 75

Escalloniaceae, 62

Eucalyptus, 100

Eucharis Lily, 38

Eulalia, 27

Eupatorium, 144

Euphorbia, 84

Euphorbiaceae, 81

Evening Primrose, 102

Everlasting, 145

Evolvulus, 117

Fabaceae, 69

Fagaceae, 45

Fagara, 78

False Cromwell, 122
False Dandelion, 153

False Foxglove, 130

False Garlic, 35

False Hellebore, 33

False Ipecac, 136

False Nettle(Bohmeria) 47

False Pimpernel, 128

Fan-palm, 28

Farkle-berry, 108

Fern Family, 20

Ferns, 19

Fetter Bush, 107

Ficus, 48

Fig, 48

Figwort Family, 127

Fire-weed, 145

Fishtail-palm, 28

Fittonia, 131

Flax, 77

Fleabane, 146

Fleur-de-lis, 38

Floating Heart, 113

Flowering-fern Fam. 19

Fly-poison, 33

Fountain-plant, 129

Four-o'clock Family, 52

Fragaria, 64

Frangulaceae, 88

Fraxinus, 111

Freesia, 39

French Mulberry, 124

Fringed Orchis, 41

Fringe-tree, 112

Fritillaria, 35

Froelichia, 51

Frog's bit Family, 27

Frost-grape, 89

Frostweed, 94

Fuchsia, 102

Gaillardia, 150

Galactia, 75

Galanthus, 38

Galium, 135

Garberia, 143

Gardenia, 135

Garlic, 35

Gaura, 101

Gaylussacia, 108

Geiger-tree, 122

Gelsemium, 112

Gentian Family, 112 
Geobalanus, 66

Geranium Pamily, 76

Gerardia, 129

Germander, 124

Gherkin, 138

Gilia, 119

Ginger Pamily, 39

Ginseng, 104

Gladiolus, 39

Glass-wort, 50

Gleditschia, 68

Glottidium, 72

Glycine, 76

Gnaphalium, 145

Goat's rue, 71

Gold and Silver Ferns, 22

Golden Aster, 147

Golden Club, 29

Golden Dewdrop, 123

Goldenrod, 147

Gonolobus, 115

Goober, 76

Goose-flower, 138

Goosefoot Pamily, 50

Gopher-apple, 66

Gordonia, 93

Gossypium, 91

Goumi, 97

Gourd Family, 138

Gramineae, 27

Granadilla-vine, 96

Grape Family, 89

Grape-fruit, 79

Grasses, 27

Grass-fern, 20

Grass-pink, 42

Gratiola, 123

Grevillea. 97

Ground Cherry, 120

Ground Nut, 76

Ground Oak, 66

Groundsel, 146

Guava, 100

Gumbo, 91

Gum-elastic, 110

Gum-tree, 100

Gunneraceae, 102

Gymnadenia, 41

Gymnadeniopsis, 41

Gymnogramma, 22

Gymnoepermae, 9, 23

Gyrostachie, 11
Gyrotheca, 39

Habenaria, 41

Hackberry, 48

Haemodoraceae, 39

Halorrhagaceae, 102

Hamelia, 135

Hartwrightia, 143

Haw, 136

Hawk-weed, 153

Hawthorn, 65

Hazelnut Pamily, 45

Heath Family, 107

Hederaceae, 103

Hedeoma, 127

Hedge-hyssop, 128

Hedge-nettle, 125

Hedge-pink, 55

Helenium, 146

Helianthemum, 94

Helianthus, 151

Heliotrope, 122

Hemp Pamily. 47

Henna Bush. 99

Hibiscus, 91

Hicoria, 43

Hieracium, 153

Hippocastanaceae, 87

Hoarhound, 125

Hog-plum, 67

Holly Family, 85

Holly-ferm, 21

Hollyhock, 91

Honey-locust, 68

Honeysuckle, 136, 137

Hop, 47

Hornbeam, 45

Hornwort Family, 55

Horse-nettle, 120

Horse-mint, 125

Houseleek, 61

Houstonia, 136

Hoya, 115

Huckleberry Family, 108

Humulus, 47

Hyacinth, 35

Hydrangea, 62

Hydrocharitaceae, 27

Hydrocotyle, 104

Hydrolea, 119

Hydropterides, 23

Hymenocallie. 37
Hypericaceae, 92

Hypericum, 93

Hypocrit, 84

Hypoxis, 38

Hyptis, 126

Ilex, 86

Ilicaceae, 85

Illecebraceae, $\mathbf{5 1}$

Illicium, 56

Ilysanthes, 128

Impatiens, 77

Indian Chickweed, 53

Indian Corn, 27

Indian Cress, 77

Indian Lotus, 58

Indian Mallow, 90

Indian Pipe, 106

Indian Plantain, 143

Indian Turnip, 29

Indigofera, 71

Indigo-plant, 71

Ink-berry, 86

Ipomcea, 118

Iridaceae, 38

Iris, 38

Iron-weed, 143

Iron-wood, 110

Isnardia, 101

Isoetaceae, 23

Italian Rye-grass, 28

Iteaceae, 62

Iva, 141

Ivy Family, 103

Ixia, 39

Ixiaceae, 38

Jacaranda, 133

Jacobinia, 131

Jack-in-the-pulpit, 29

Japan-plum, 66

Japonica, 93

Jasmine, 111, 114

Jatropha, 83

Jersey-tea, 88

Jerusalem Pine, 25

Jerusalem Thorn, 69

Jessamine, Cape, 135

Jessamine, Confederate, 114

Jessamine, Day, 121

Jessamine, Night-blooming, 121 
Jessamine Potato, 120 Jessamine, Star, 114 Jessamine, Yellow, 112 Jewel-weed, 77 Jimson-weed, 121 Joint-vetch, 73 Jointweed, 49 Jonquil, 38 Juglandaceae, 43 Juncaceae, 34 Juniper Family, 24 Jussiaea, 101 Justicia, 131

Kalmiella, 107

Kentia, 28

Kidglove, 79

Kidney-bean, 76

Kohlrabi, 59

Koniga, 59

Kosteletzkya, 90

Krigia, 152

Kudzu-vine, 74

Kuhnistera, 72

Kumquat, 79

Labiatae, 124

Lachnanthes, 39

Lachnocaulon, 31

Laciniaria, 144

Lactuca, 153

Ladies' tresses, 41

Lady-fern, 21

Lagenaria, 138

Lagerstroemia, 99

Lamiaceae, 124

Lantana, 123

Latania, 28

Lathyrus, 70

Lauraceae, 97

Laurel Bay, 57

Laurel Family, 97

Laurocerasus, 66

Lawsonia, 99

Leadwort, 109

Leaf-cup, 149

Lechea, 94

Lemna, 29

Lemon, 79

Lentibulariaceae, 131

Leonotis, 125

Lepidium, 59
Leptocaulis, 105

Lespedeza, 74

Lettuce, Garden, 153

Lettuce, Water, 29

Leucanthemum, 146

Leucojaceae, 37

Liatris, 143

Ligustrum, 112

Lilac, 111

Lily Family, 35

Lily-of-the-Valley, Fam. 35

Lime, 79

Limnanthemum, 113

Limnobium, 27

Limodorum, 42

Limonium, 109

Linaceae, 77

Linaria, 128

Lippia, 123

Liquildamber, 63

Liriodendron, 56

Livistonia, 28

Lizard's tail Family, 42

Lobelia, 140

Loblolly-bay, 93

Locust, 71

Loganiaceae, 112

Lolium, 28

Lonicera, 136

Loosestrife, 99

Loquat, 66

Loranthaceae, 134

Lorinseria, 21

Lotus, 58

Love-vine, 119

Lucerne-clover, 70

Ludwigia, 101, 102

Luffa, 139

Lupinus, 70

Lycium, 121

Lycopersicon, 120

Lycopodium, 22

Lygodesmia, 153

Lygodium, 22

Lythraceae, 99

Macartney-rose, 64

Madder Family, 134

Madeira Redwood, 79

Madeira Vine, 53

Magnolia Family, 56

Mahogany, 79, 98
Maidenhair, 20

Malus, 65

Mallow Family, 89

Malvaceae, 89

Malvaviscus, 90

Mandarin, 79

Mangelwurtzel, 50

Mangrove, 100, 124

Manihot, 83

Maple Family, 87

Maranta, 40

Marrubium, 125

Marsh Cress, 59

Marsh Elder, 141

Marsh Fleabane, 145

Marsh Pennywort, 104

Marsh Pink (Sabbatia) 113

Marsh Purslane, 101

Marsh Rosemary, 109

Marsh St. John's wort, 92

Matrimony-vine, 121

Mayaca Family, 29

May-pop, 95

Meadow-beauty Fam. 98

Meadow-garlic, 35

Medic, 70

Medicago, 70

Meibomia, 73

Melanthaceae, 32

Melanthium, 34

Melanthera, 142

Melastomaceae, 98

Meliaceae, 79

Melothria, 138

Mentha, 126

Menyanthaceae, 113

Mercury, 82

Mesadenia, 143

Mesosphaerum, 126

Mexican Poppy, 58

Mexican Vine, 49

Meyenia, 131

Michelia, 57

Micranthemum, 128

Micromeria, 125

Microstylis, 42

Mignonette, 60

Mikania, 145

Milk-pea, 75

Milkweed, 116

Milkwort Family, 80

Mimosa Family, 67 
Mimosa-tree, 67

Mimulus, 129

Mint Family, 124

Mirabilis, 53

Mist-flower, 144

Mistletoe, 134

Mitchella, 136

Mitreola, 112

Mitre-wort, 112

Mock-orange, 62

Modiola, 91

Mollugo, 53

Monarda, 125

Moakey-flower, 129

Monocotyledones, 10, 25

Monotropaceae, 106

Moonwort. 19

Moraceae, 47

Morella, 44

Morning-glory Fam. 117

Morongia, 67

Morus, 47, 48

Mountain-ebony, 68

Mucuna, 76

Mulberry Family, 47

Muricanda, 29

Musn, 39

Muscadine, 89

Musk-melon, 138

Mustang-grape, 89

Mustard Family, 58

Myricaceae, 44

Myriophyllum, 103

Myrtle Family, 100

Nama, 119

Narcissus, 38

Nasturtium, 59, 77

Necklace-tree, 71

Needle-palm, 28

Negundo, 87

Nelumbo, 58

Nemastylis, 39

Nemexia, 36

Neo-Washingtonia, 28

Nephrolepis, 21

Nerium, 114

Nessea, 99

Nettle, 47

Nicotiana, 121

Night-blooming Cereas, 96

Night-shade Pam. 119
Nintooa, 136

Norfolk Island Pine, 25

Nothoscordium, 35

Nuphar, 58

Nutmeg-melon, 138

Nyctaginaceae, 52

Nymphaea, 58

Nymphoides, 113

Nyssaceae, 103

Oak, 45

Oenothera, 102

Okra, 91

Oleaceae, 110

Oleander, 114

Oleaster, 97

Olive Family, 110

Onagraceae, 101

Onion Family, 34

Onosmodium, 122

Ophioglossum, 19

Opopanax, 67

Opuntiaceae, 96

Orache, 50

Orange, 78

Orange-grass, 93

Orchid Family, 40

Ormosia, 71

Orobranchaceae, 132

Orontium, 29

Orpine Family, 61

Osage-orange, 48

Osmanthus, 111

Osmunda, 19

Ostrich-feather, 21

Oxalidaceae, 77

Ore-eye Daisy, 146

Oxypolis, 106

Oxytria, 35

Padus, 67

Paeonia, 55

Paepalanthus, 31

Pagoda-tree, 69

Painted Leaf, 84

Palafoxia, 146

Paliuris, 69

Palma Christi, 83

Palmetto, 28

Palm Pamily, 28

Pampas-grass, 27

Panax, 104
Pancratium, 37

Panda nus, 25

Pansy, 95

Papaveraceae, 58

Papaw, 56

Papilionaceae, 69

Parietaria, 47

Parkinsonia, 69

Paronychia, 52

Parrot's Feather, 103

Parsley, 106

Parthenocissus, 89

Partridge-berry, 136

Passifloraceae, 95

Passion-flower, 95

Peach, 66

Pea Family, 69

Peanut, 76

Pear, 65

Pecan, 43

Pedilanthus, 84

Pelargonium, 76

Pelican-flower, 138

Pellitory, 47

Peltandra, 29

Pencil-flower, 73

Pennyroyal, 127

Pennywort, 104

Penthoraceae, 61

Pentstemon, 128

Peony, 55

Peperomia, 43

Pepper, black and white, 43

Pepper, red and green, 120

Pepper-grass, 59

Peppermint, 126

Pepper-vine, 89

Pepper-wood, 78

Periwinkle, 114

Persea, 98

Persicaria, 49

Persimmon, 110

Petalostemon, 72

Petunia, 121

Pharbitis, 118

Phaseolus, 76

Philadelphus, 62

Philotria, 27

Phlebodium, 20

Phlox Pamily, 119

Phoenix, 28

Phoradendron, 134 
Photinia, 66

Phrynium, 40

Phyla, 123

Phyllantus, 82

Phyllocactus, 96

Physalis, 120

Physostegia, 125

Phytolacca, 52

Piaropus, 32

Pickerel-weed, 32

Pie-plant, 49

Pieris, 107

Pigeon-berry, 52

Pignut, 44

Pigweed, 50, 51

Pinaceae, 23

Pine-apple Family, 32

Pine Family, 23

Pine-tassle, 93

Pinguiculaceae, 131

Pink Family, 54

Pinkneya, 135

Piperaceae, 43

Pipe-wort Family, 30

Piriqueta, 94

Pistia, 28

Pisum, 70

Pitcher-plant, 61

Pittosporum, 62

Plane-tree, 63

Plantaginaceae, 134

Plantain, 134

Platanaceae, 63

Platanthera, 41

Platycerium, 21

Pleea, 33

Pleurisy-root, 116

Pluchea, 145

Plumbago Family, 109

Plum Family, 66

Poaceae, 27

Podostigma, 116

Pogonia, 42

Poinciana, 68

Poinsettia, 84

Poison Hemlock, 105

Poison Ivy, 85

Poison Oak, 85

Poke-weed, 52

Polecat-geranium, 123

Polemoniaceae, 119

Polyanthes, 38
Polygalaceae, 80

Polygonaceae, 48

Polygonella, 49

Polymnia, 149

Polypodiaceae, 20

Polypremum, 112

Polypteris, 146

Polystichum, 21

Pomaceae, 65

Pomegranate, 100

Pomelo, 79

Pond-lily, 58

Pondweed Family, 26

Pontedariaceae, 32

Ponthieva, 41

Pop-ash, 111

Popinac (See Opopanax) 67

Poplar, 44

Poppy Family, 58

Populus, 44

Portulaca, 54

Possum-haw, 86

Potamogeton, 26

Potato, Irish, 121

Potato, Sweet, 118

Potato-jessamine, 120

Prairie-clover, 72

Prairie Rose, 64

Prenanthes, 153

Prickly Ash, 78, 104

Prickly Pear, 96

Pride-of-India, 80

Primrose Family, 109

Primulaceae, 109

Privet, 112

Proserpinaca, 102

Proteaceae, 97

Prunus, 66

Psidium, 100

Psilotum, 22

Psoralea, 72

Pteridium, 21

Pteridophyta, 9, 19

Pteris, 20

Pterocaulon, 145

Pueraria, 74

Pumpkin, 139

Punica, 100

Purslane Family, 53

Pusley, 54

Pycnothymus, 125

Pyrrhopappus, 153
Pyrus, 65

Quamasia, 35

Quamoclit, 118

Queen-cactus, 96

Queen-root, 83

Queen's delight, 83

Quercus, 45

Quillwort, 23

Rabbit-tobacco, 145

Radish, 60

Rag-gourd, 139

Ragweed Family, 140

Rainbow-moss, 23

Rambler, 64

Ranunculaceae, 55

Raphanus, 60

Raspberries, 64

Rattle-box, 70

Rattlesnake-fern, 19

Red Bay, 98

Red Cedar, 25

Red Lily, 35

Redroot, 88

Rein-orchid, 41

Reseda, 60

Resurrection-fern, 20

Resurrection plants, 23, 60

Rhamnaceae, 88

Rhapidophyllum, 28

Rheum, 49

Rhexia, 98

Rhinanthaceae, 127

Rhizophora, 100

Rhubarb, 49

Rhus, 85

Rhynchosia, 74

Rhyncospermum, 114

Rice-paper plant, 104

Richardia, 29

Richardsonia, 136

Ricinus, 83

Rivina, 52

Robinia, 71

Rochea, 61

Rock-rose Family, 94

Roripa, 59

Rosaceae, 63

Rosa-de-Montana, 49

Rose-mallow, 91

Rose-moss, 54 
Rose of Jericho, 60

Rose of Sharon, 91

Royal-fern, 19

Rubber-plant, 48

Rubiaceae, 134

Rubus, 64

Rudbeckia, 150

Rue Pamily, 78

Ruellia, 130

Rulac, 87

Rumex, 49

Ruppia, 26

Rush Family, 34

Russelia, 129

Rutaceae, 78

Rye-gras's, 28

Sabal, 28

Sabbatia, 113

Sabina, 25

Saccharum, 27

Sage, 127

Sageretia, 88

Sagittaria, 26

Sago-palm, 23

Salicornia, 50

Salix, 44

Salvia, 127

Salvinia Pamily, 23

Sambucus, 136

Samolus, 109

Samphire, 50

Sanicula, 105

Sansevieria, 36

Sapindaceae, 87

Sapium, 83

Sapodilla Family, 110

Saponaria, 55

Sapotaceae, 110

Sarothra, 92

Sarraceniaceae, 60

Sassafras, 98

Satsuma, 79

Sacureia, 125

Saururus, 43

Scallop, 139

Schizandra, 57

Schoe nocaulon, 33

Schoenolirion, 35

Schrankia, 67

Schwalbia, 127

Scilla, 35
Scoparia, 130

Screw-pine Family, 25

Scrophulariaceae, 127

Scuppernong-grape, 89

Scutellaria, 126

Sea Ash, 78

Seaforthia, 28

Sea-Grape, 49

Sea Lavender, 109

Sea Oats, 27

Sea Ox-eye, 149

Sea Purslane, 53

Sea Rocket, 59

Sebesten, 122

Sedge Family, 27

Sedum, 61

Selaginella, 22

Sempervivum, 61

Senecio, 146

Senna Family, 68

Sensitive Brier, 67

Sensitive Pea, 68

Sensitive Plant, 68

Serenoa, 28

Sericocarpus, 148

Sesbania, 72

Sesuvium, 53

Seutera, 115

Seymeria, 130

Shaddock, 79

Shakewood-tree, 48

Sheep-sorrel, 49

Shield-fern, 21

Shoestring-vine, 89

Shrubby Althaea, 91

Sida, 90

Silene, 54

Silk-oak, 97

Silver Pampas-grass, 27

Siphonychia, 51

Sisymbrium, 59

Sisyrynchium, 39

Sitilias, 153

Sium, 106

Skull-cap, 126

Sleepy Catchfly, 54

Sloe, 136

Smartweed, 49

Smilax, 36

Snake-root, 137

Snecze-weed. 146

Snow-bush, 82
Snow-drop, 38

Snow-flake, 38

Soapberry, 87

Solanaceae, 119

Solidago, 147

Sonchus, 153

Sophia, 59

Sophora, 69

Sophronante, 128

Sorrel, 49, 77

Sour-grass, 78

Sow-thistle, 153

Soy-bean, 76

Spanish Bayonnet, 36

Spanish Cocklebur, 90

Spanish Daggers, 36

Spanish Moss, 32

Sparganiaceae, 25

Sparkle-berry, 108

Spatter-dock, 58

Specularia, 140

Speedwell, 128

Spermatophyta, 23, 25, 42

Spermolepis, 105

Spider-lily, 37

Spiderwort Family, 31

Spigeliaceae, 112

Spilanthes, 149

Spinach, 50

Spiraea, 64

Spiranthes, 41

Spirodela, 29

Spleenwort, 21

Spondiaceae, 85

Spurge Family, 81

Spurge Nettle, 83

Squash, 139

Squaw-root, 132

Squaw-weed, 146

Squill, 35

Stachys, 125

Stagger-bush, 108

Staghorn-fern, 21

Star Grass, 38

Star Jessamine, 114

Statice, 109

St. Andrew's-cross, 92

St. Augustine-grass, 27

St. John's-wort, 92, 93

St. Lucie-grass, 27

St. Peter's-wort, 92

Stellaria, 54 
Stemmadenia, 114

Stenanthium, 33

Stenolobium, 133

Stenotaphrum, 27

Sterculiaceae, 91

Stillingia, 83

Stipulicida, 54

Stone-crop, 61

Stork's bill, 76

Strawberry, 64

Strawberry Shrub, 65

Stretch-berry, 37

Strobilanthus, 131

Stylisma, 117

Stylosanthes, 73

Sugar-cane, 27

Sumac, 85

Sundew, 60

Sun-flower, 151

Svida, 103

Swamp Honeysuckle, 107

Sweet Alyssum, 59

Sweet Bay, 57, 98

Sweet Flag, 29

Sweet Gum, 63

Sweet Myrtle, 100

Sweet Pea, 70

Sweet Potato, 118

Sweet-scented Shrub, 65

Sweet Violet, 95

Swietenia, 79

Sword-fern, 21

Sycamore, 63

Syngonanthus, 31

Syringa, 111

Tabernæmontana, 114

Tallow-tree, 83

Tamaceae, 38

Tamala, 98

Tangerine, 79

Tansy-mustard, 59

Tape-grass Family, 26

Taxodium, 24

Tea, 93

Tea-olive, 111

Tecoma, 133

Tephrosia, 71

Tetragoniaceae, 53

Teucrium, 124

Thalia, 40

Theaceae, 93
Thevetia, 114

Thistle, 142

Thistle Family, 141

Thorn-apple, 121

Thread-palm, 28

Thrinax, 28

Thuja, 24

Thunbergia, 131

Thyrsanthema, 149

Tick-seed, 151

Tick-trefoil, 73

Tiedemannia, 106

Tillandsia, 32

Tiniaria, 49

Tithymalus, 84

Tium, 71

Toad-flax, 128

Tobacco, 121

Toddy-palm, 28

Tofieldia, 33

Tomatillo, 120

Tomato, 120

Toothache-tree, 78

Touch-me-not, 77

Toxicodendron, 85

Toxylon, 48

Trachelospermum, 114

Tracyanthus, 33

Tradescantia, 31

Tragia, 82

Trailing-arbutus, 107

Tree-huckleberry, 108

Tree-ferns, 22

Tree-orchis, 42

Triadenum, 92

Triantha, 33

Trichostema, 126

Trifolium, 70

Trilisa, 143

Tropæolum, 77

Trumpet-creeper, 133

Trumpet-flower, 133

Trumpet-leaf, 61

Tuberose, 38

Tubiflora, 130

Tulip, 35

Tulip-tree, 56

Tumble-weed, 51

Tuna-cactus, 96

Turkey-beard, 33

Turk's Turban, 123

Turneraceae, 94
Turnip, 59

Turtle-head, 129

Twin-berry, 136

Twisted-orchis, 41

Typhaceae, 25

Ulmaceae, 48

Ulmus, 48

Umbelliferae, 104

Umbrella-fern, 27

Umbrella-tree, 80

Uniola, 27

Urena, 90

Urticaceae, 47

Utricularia, 132

Vaccinium, 108

Vachellia, 67

Valentine-flower, 132

Valerian, 137

Vallisneria, 27

Vanilla-plant, 143

Velvet-bean, 76

Velvet-leaf, 90

Venus-hair, 20

Venus' looking-glass, 140

Veratrum, 33

Verbenaceae, 122

Verbesina, 149

Vernonia, 143

Veronica, 128

Vervain, 122

Vetch, 70

Viburnum, 136

Vicia, 70

Vigna, 76

Vinca, 114

Vincetoxicum, 115

Violaceae, 94

Violet Family, 94

Virginia Creeper, 89

Virginia, Stone-crop, 61

Virginia Willow, 62

Vitaceae, 89

Vitex, 123

Vitis, 89

Vittaria, 20

Walking-ferns, 20

Walnut Family, 43

Wampee, 32

Wandering-Jew, 31 


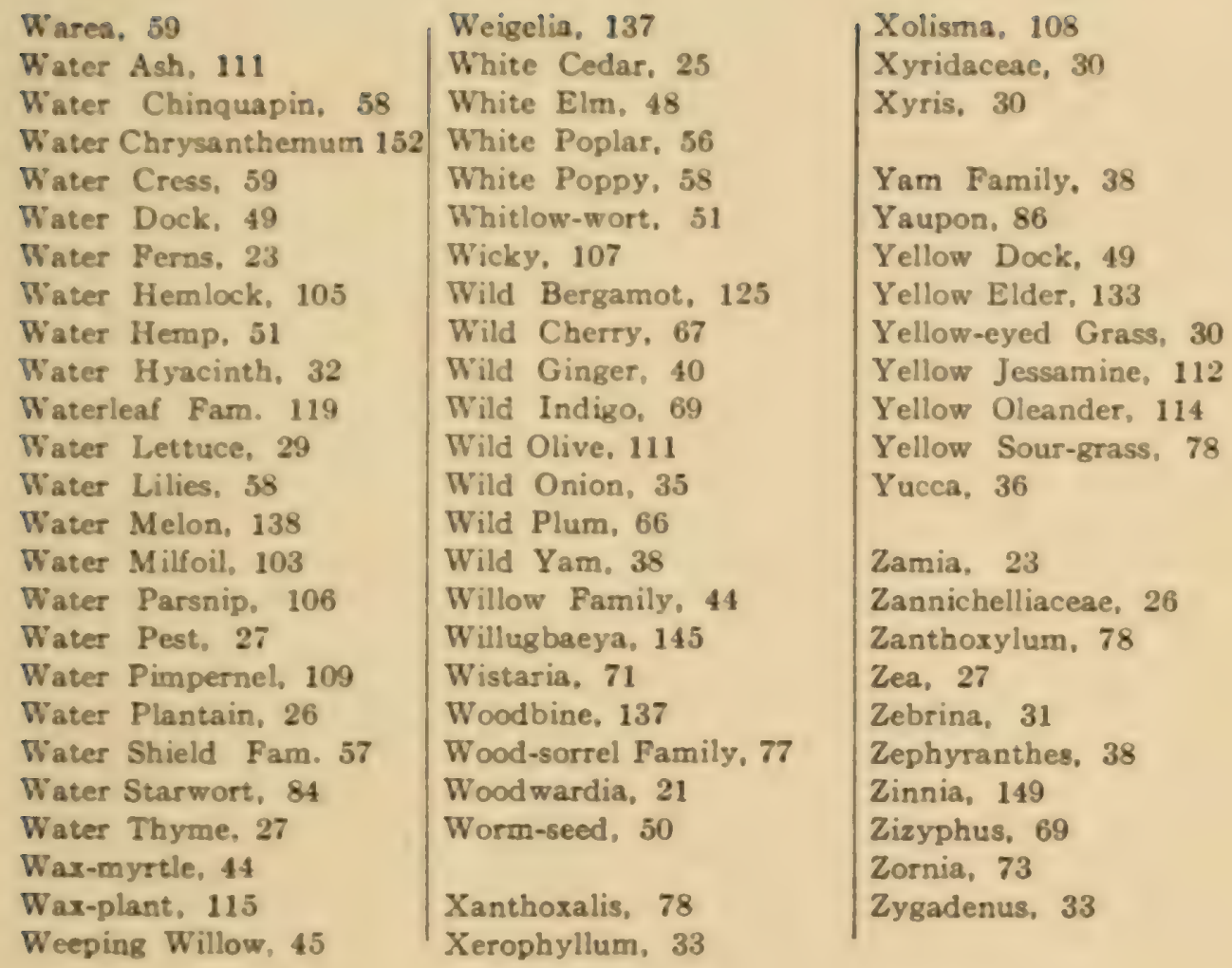


81

$71275 S$ B 59 



Y E Tax IN $\mathrm{s}+\mathrm{N}$ $10=8$

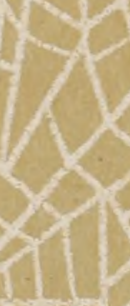




\section{New York Botanical Garden Library}

QK $143 . B 221914$

Baerecke, John Fred/Analytical key to th

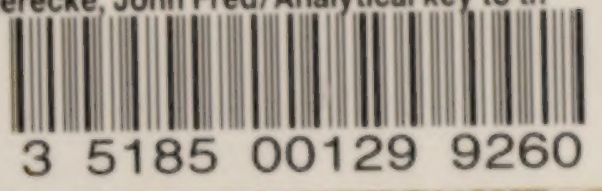

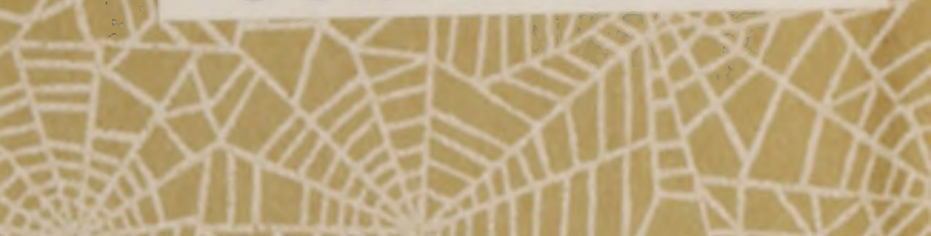


